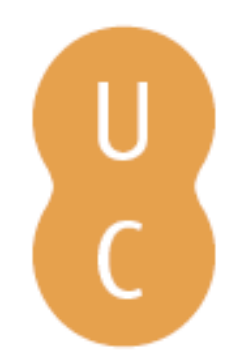

\title{
nommalina
}

\section{Ensaios sobre Mário de Carvalho}

Publicado por: Imprensa da Universidade de Coimbra; Centro de Estudos Clássicos e

URL

persistente:

URI:http://hdl.handle.net/10316.2/9729

DOI:

DOI:http://dx.doi.org/10.14195/978-989-26-0548-7

Accessed : $\quad$ 26-Apr-2023 15:56:27

A navegação consulta e descarregamento dos títulos inseridos nas Bibliotecas Digitais UC Digitalis, UC Pombalina e UC Impactum, pressupõem a aceitação plena e sem reservas dos Termos e Condições de Uso destas Bibliotecas Digitais, disponíveis em https://digitalis.uc.pt/pt-pt/termos.

Conforme exposto nos referidos Termos e Condições de Uso, o descarregamento de títulos de acesso restrito requer uma licença válida de autorização devendo o utilizador aceder ao(s) documento(s) a partir de um endereço de IP da instituição detentora da supramencionada licença.

Ao utilizador é apenas permitido o descarregamento para uso pessoal, pelo que o emprego do(s) título(s) descarregado(s) para outro fim, designadamente comercial, carece de autorização do respetivo autor ou editor da obra.

Na medida em que todas as obras da UC Digitalis se encontram protegidas pelo Código do Direito de Autor e Direitos Conexos e demais legislação aplicável, toda a cópia, parcial ou total, deste documento, nos casos em que é legalmente admitida, deverá conter ou fazer-se acompanhar por este aviso. 
do Tempo e da História

- Mário de Carvalho e a reflexáo metaficcional sobre o futuro do romance - Sátiva e o cepticismo: configuração de personagens em Mário de Carvalho - Escrever tem arte e tem segredos... Era bom que trocássemos umas ideias sobre o assunto - O processo criativo em Era bom que trocássemos umas ideias sobre o assunto - Intertextualidade e metaficção em Fantasia para dois Coronéis e uma Piscina, de Mário de Carvalho - Trimalquiāo, os coronéis e a piscina: retrato impiedoso de um pais em crise $\bullet A$ Paixão do Conde de Fróis: paródia e subversão • "Como dizia o outro": a presença dos Clássicos em Mário de Carvalho - Cultura Clássica em Um

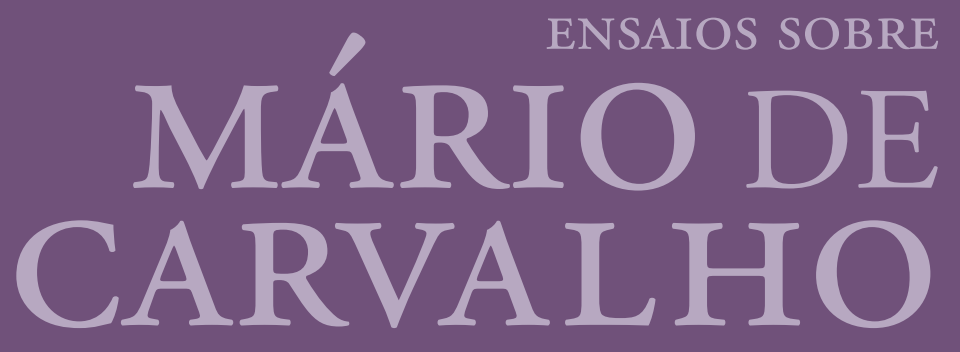

Maria de Fátima Silva Tereza Virgínia Ribeiro Barbosa COORD. IMPRENSA DA UNIVERSIDADE DE COIMBRA COIMBRA UNIVERSITY PRESS

elemento mouro como simbolo de alteridade $e$ barbárie em Um deus passeando pela brisa da 
Poetas, pintores, escultores, na Antiguidade, familiarizados com mitos antigos de deuses e de homens, que cristalizavam experiências, interrogaçōes, respostas quanto à existência do homem no tempo e no mundo, neles se inspiraram, em contínua criação-recriação para neles verterem a sua própria experiência temporal, com todos os desassossegos e inquietaçóes, com todo o espanto, horror ou encantamento pela excepcionalidade da acçáo humana, que rasga ou ilumina fronteiras de finitude.

Este é um património que constitui a linguagem cultural do que somos, que, ao longo dos séculos, criou laços de pertença, sentida, com as matrizes do Ocidente e que se foi enriquecendo nas sucessivas apropriaçóes recriadoras em que o 'novo' incessantemente está presente, dada a inesgotabilidade da própria vivência humana, correspondente à riqueza e diversidade que a caracterizam e que caracterizam a diversidade e diferenciaçáo de cada época, de cada espaço cultural desse mesmo Ocidente. O mito, no seu sentido etimológico, continua a oferecer-se como espaço de cristalização de vivências temporais novas e espaço de encontro com antigas vivências, diversas e porventura afins.

Esta consciência, como é sabido, é problematizada por filósofos e tem operado como motor de criaçáo quanto à poiesis de todos os tempos, até hoje, configurando, inclusivamente, enquanto mythos, momentos da História Antiga ou espaços de memória. Esses percursos da criaçáo merecem, hoje, a atenção e estudo dos Estudos Literários e, como não podia deixar de ser, dos Estudos Clássicos, muito peculiarmente.

Com o dealbar dos anos cinquenta do séc. XX foram publicados os primeiros trabalhos de investigação, nesta área, dos que viriam, então, a ser fundadores, em 1967, do Centro de Estudos Clássicos e Humanísticos. Fundado o Centro, já tal área de estudos, por ele integrada, constituía uma tradição - traditio laureata, inclusivamente - no seio dos seus primeiros investigadores. E de moto continuo ela veio sendo alargada e consolidada, em inúmeras publicaçóes que constituem volumes temáticos, várias vezes reeditados, artigos, colaboraçôes de contributo em actas de congressos, em Portugal ou no estrangeiro, bem como em seminários de $2^{\circ}$ e $3^{\circ}$ ciclo e no número substancial de dissertaçôes a que já deu origem (algumas delas já publicadas). A partir dessa face do Centro veio a consolidar-se o diálogo e interacção com poetas, dramaturgos, encenadores, cineastas; a partir dessa face se veio o Centro a integrar, por convite, na Network research on Greek Drama (Atenas-Oxford), com resultados já publicados em volumes.

Importava, pois, fazendo jus a tal tradição de mais de meio século, proceder à publicaçáo sistemática de estudos deste cariz, dedicados, sobretudo, a autores de língua portuguesa, reeditando ou reunindo o que andava disperso e acrescentando-lhe a incessante nova produção ensaística. Assim se inaugura a linha editorial do CECH/ Classica Digitalia, MITO E (RE)ESCRITA.

Maria do Céu Fialho

Coordenadora do Centro de Estudos Clássicos e Humanísticos 


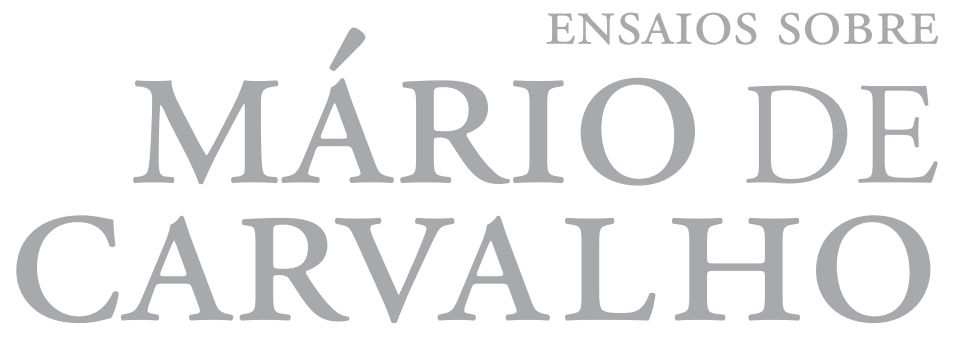

Maria de Fátima Silva

Tereza Virgínia Ribeiro Barbosa COORD. 
Todos OS VOLUMES DESTA SÉRIE SÃO SUJEITOS A ARBITRAGEM CIENTÍFICA INDEPENDENTE.

Título • Ensaios sobre Mário de Carvalho

Coordenação • Maria de Fátima Silva e Tereza Virgínia Ribeiro Barbosa

Série Mito e (Re)Escrita

Coordenador Científico do plano de ediçấo: Maria do Céu Fialho

Conselho Editorial

José Ribeiro Ferreira

Francisco de Oliveira

Maria de Fátima Silva

Nair Castro Soares

Director Técnico: Delfim Leão

OBRa REALIZADa No ÂMBito DAS ACTIVIDADES DA UI\&D

Centro de Estudos Clássicos e Humanísticos

\section{EDIÇÃo}

Imprensa da Universidade de Coimbra

URL: http://www.uc.pt/imprensa_uc

E-mail: imprensauc@ci.uc.pt

Vendas online:

http://livrariadaimprensa.uc.pt

\section{COORDENAÇÁO EDITORIAL}

Imprensa da Universidade de Coimbra

Concepçấo gráfica \& Paginação

Carlos Costa

Pré-IMPRESSÃo

Carlos Costa
Impressão e Acabamento

Tipografia Lousanense

ISBN

978-989-26-0542-5

\section{ISBN DigitaL}

978-989-26-0548-7

\section{DOI}

http://dx.doi.org/10.14195/:978-989-26-0548-7

Depósito Legal

$353355 / 12$

1a EDIÇÃo: IUC/CECH • 2012

C) Dezembro 2012.

IMPRENSA DA UNIVERSIDADE DE COIMBRA

Classica Digitalia Vniversitatis Conimbrigensis (http://classicadigitalia.uc.pt)

Centro de Estudos Clássicos e Humanísticos da Universidade de Coimbra

Reservados todos os direitos. Nos termos legais fica expressamente proibida a reproduçáo total ou parcial por qualquer meio, em papel ou em edição electrónica, sem autorização expressa dos titulares dos direitos. É desde já excepcionada a utilização em circuitos académicos fechados para apoio a leccionaçáo ou extensáo cultural por via de e-learning. 


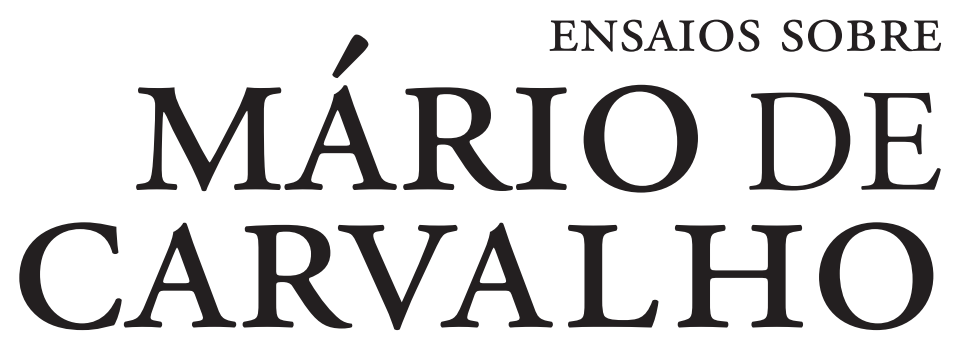

Maria de Fátima Silva

Tereza Virgínia Ribeiro Barbosa COORD. 
(Página deixada propositadamente em branco) 


\section{SUMÁRIO}

Mário de Carvalho, O carro de Apolo

Maria de Fátima Silva, Tebas. A imagem literária do Tempo e da História em Mário de Carvalho

José Cândido de Oliveira Martins, Mário de Carvalho e a reflexão metaficcional sobre o futuro do romance

Maria João Simóes, Sátira e o cepticismo: configuração de personagens em Mário de Carvalho

Maria de Fátima Silva, Escrever tem arte e tem segredos ... Era bom que trocássemos umas ideias sobre o assunto.

Ana Paula Arnaut, O processo criativo em Era bom que trocássemos umas ideias sobre o assunto

Rosana Baptista dos Santos, Intertextualidade e metaficção em Fantasia para dois Coronéis e uma Piscina, de Mário de Carvalho.

António Manuel Gonçalves Mendes, Trimalquiāo, os coronéis e a piscina: retrato impiedoso de um pais em crise

Ana Paula Arnaut, A Paixão do Conde de Fróis: paródia e subversão

Virgínia Soares Pereira, "Como dizia o outro": a presença dos Clássicos em Mário de Carvalho...

António Manuel Gonçalves Mendes, Cultura Clássica em Um deus passeando pela brisa da tarde de Mário de Carvalho

Carla Carvalho Alves, O lado errado do Marenostro: o elemento mouro como símbolo de alteridade e barbárie em Um deus passeando pela brisa da tarde

Rosana Baptista dos Santos, Fabulário: (Re)contando mitos

Tereza Virgínia Barbosa, Neoars moriendi: Mário de Carvalho e a nova arte de morrer.

Bibliografia geral 
(Página deixada propositadamente em branco) 


\section{O carro de Apolo}

Mário de Carvalho 
(Página deixada propositadamente em branco) 


\section{— Mário, diz lá quem foi Mário?}

Naquele tempo, havia uma instituição designada por "chamadas» que se manifestava sombriamente nos sumários das aulas (o livro de ponto negrejando sobre a secretária, ao lado da caderneta, acastanhada e sinistra). Para o acto, alguns professores mais modernos utilizavam o eufemismo «revisóes». Não era o caso na aula de História.

O velho mestre, paciente e amável, conduziu-nos arrastadamente pelos meandros do passado durante três anos. Desde o paleolítico à primeira Guerra Mundial, se bem me lembro, então considerada o fim da história, até ser malogradamente decretado outro fim, trinta e cinco anos mais tarde.

Durante esse ciclo, antes de nos devolver os testes (com correcçóes mínimas- pontos de interrogação minúsculos e, sobretudo, pontos de exclamação!) reclinava-se tristemente na cadeira e exalava um fatigado discurso que começava sempre (mas sempre!) pela seguinte frase: «de uma maneira geral (pausa e olhar panorâmico, entristecido) os pontos (última sílaba sibilando, olhos contemplando o tecto) não satisfizeram (stacatto duramente marcado).

Naquela manhã, achou graça associar o meu nome ao do romano. Eu por acaso sabia o mínimo exigido sobre o cônsul Caio Mário. A simpatia onomástica levara-me a dar especial atenção ao capítulo das guerras civis em Roma. Tinha então doze anos e podia mencionar, muito vagamente, Mário e a reorganização das legiôes e Silla e as proscriçôes.

Era este conhecimento inútil e livresco? Inadequado a um miúdo de doze anos? Nem tanto. Foi-me útil nas aulas de latim, mais tarde, e, de certo modo, fundou conhecimentos que tornaram mais reconhecível o contexto da compacta cadeira de direito romano, recheada de citaçóes latinas, com notas de página inteira de texto jurídico, já fora do nosso alcance linguístico, mas à disposição de quem quisesse comprovar os fragmentos das doze tábuas ou os brocardos de Papiniano, Paulo, Gaio, Ulpiano e Modestino, que a minha péssima memória ainda evoca pela mnemónica PPGUM, como na Idade-Média.

Devo, com justiça, anotar que o meu professor de Direito Romano, o Doutor Raul Ventura, tinha um senso de humor raro, entre os docentes da faculdade, e ainda por cima, em torno de matéria tão árida. Talvez nesse espírito, alguém designou a Brigite Bardot, ou outra actriz insinuante, não me lembro já, por "provocatio ad populum».

Seja como for, a telha que caía do telhado de Apius em cima da cabeça de Lucius, devido a um movimento provocado pela sua escrava Servilia, impedindo a vítima de participar num negócio «trans tiberim» com Marcus, 
liberto de Valerius, que pretendia dar de penhor o seu filho Caius numa promessa de compra de figos, foi uma boa introdução à casuística do curso e da vida profissional.

Para lá desta nota pessoal, partilhada, decerto por centenas de colegas, os horizontes formavam-se-me a partir de Grécia e de Roma, com a consciência - antes despertada - de que esse mundo pulsava na língua, no direito, nas instituiçóes, na literatura, na pintura, na arquitectura, na filosofia, na religiáo e provavelmente nos próprios comportamentos, rituais, atitudes e gestos do homem europeu dos nossos dias. $\mathrm{O}$ mundo clássico enformava um ideal interrompido que se ia reafirmando (penoso regresso), fazendo caminho através do caos e das opacidades duma Idade-Média grosseira, miserável, boçal, enferma e bruta, mas apesar de tudo, humana, e vulnerável à razão e ao progresso, que veio alastrando penosamente, a contornar as pedras como sementes germinando no cháo escuro. Hão-de me perdoar os ilustres medievalistas, repletos do saber que acumula factos e da inteligência que opera distinçóes, e que sempre me enchem de espanto e reconhecimento com a vastidão e agudeza dos seus conhecimentos, por não poder compartilhar as suas atenuaçóes e ressalvas. Um golpe de luz na treva apenas acentua a vastidáo da treva. Afigura-se-me que o velho lugar-comum, que aponta certos séculos de destruição como «idade das trevas» compartilha, infelizmente, da natureza de muitos outros lugares comuns, isto é, tem toda a razão de ser.

Após uma sucessão de catástrofes, o pouco que nós ficámos a saber é apenas um indício do muito que foi devastado... o que sobrou da destruição das bibliotecas, dos arquivos, dos edifícios, dos monumentos, dos artefactos e dos lares é uma parte ínfima, um relance do pensamento, engenho e criatividade humanas. A tese das migraçóes germânicas, pacatas, espreguiçadas e consentidas (nunca houve bárbaros, os bárbaros são os outros, etc) bem como a complacência para com os fanatismos, alinham, se não estou em erro, em propósitos branqueadores e tranquilizadoras da história, que nunca são inocentes. Não, a biblioteca de Alexandria nunca foi destruída. Todos sabemos que o papiro tem tendência para a combustão espontânea. Também foram puras casualidades, sem intenção, as destruiçôes dos Budas de Bamiyan e das mesquitas de Tombuctu.

O remoer duma ameaça surda e crescente, a sensação de cerco, um lastro histórico que a cada instante representa um «memento» fazem ecoar a romântica lamentaçáo sobre as ruinas de Palmyra de Volney. Quem destruiu Palmyra? Quem saqueou e arruinou Roma? O saque e a 
destruição esperam-nos? Seremos eternos, na mesma medida em que Roma foi eterna?

Quando publiquei Quatrocentos mil Sestércios... (envolvendo uma época indeterminada que apenas se sabe ser posterior aos Flávios) e Um Deus Passeando pela Brisa da Tarde, situado no império de Marco Aurélio, houve quem tivesse assinalado, com aquela destreza com que se ata e se dá um laçarote numa encomenda, antes de a despedir, o meu "fascínio» pela romanidade. Era bom que a vida fosse simplificada, capaz de se conter em meia-dúzia de carimbadas. Poupava incomodidades, reflexôes, maçadas, contradiçóes, paradoxos e sustos.

Ora os fascínios são apropriados às presas que se deixam levar. E eu, em matéria de escrita - noutras assim não será - sinto-me mais predador, se partirmos do princípio de que o predador observa, perturba, ataca, capta e desfibra. $\mathrm{O}$ mundo antigo (o real, náo o idealizado) era a muitos títulos pavoroso, abominável e sórdido. É de crer que nenhum de nós aí sobrevivesse mais que umas horas. Começava por ser aceite e praticado por todos o escravismo. O quotidiano, em certos casos (os heróicos espartanos...) chegava a pontos de pesadelo. Nos tempos do Império romano sobreviviam os sacrifícios humanos, na forma de combates de gladiadores, e a crueldade era norma, apesar da generalizada mania da juridicidade. Alguém chamou aos romanos «uma sociedade de cortadores de cabeças», dada a frequência com que as cabeças se alforriavam ali dos corpos. Nesse particular, a coluna de Marco Aurélio é bem elucidativa. Os especialistas que sabem infinitamente mais do que eu, poderão completar o vastíssimo quadro. Náo é sociedade que se recomende e que, em termos gerais, se proponha como modelo. Os homens da Renascença e os iluministas que abriram o mundo de hoje, no turbilháo das grandes revelaçóes (e das grandes revoluçóes, passe a figura) estavam o seu tanto equivocados.

Mas se convém deslocar a realidade, feixe de paradoxos, da zona das utopias (sempre perigosas, especialmente quando se tentam realizar) é preciso reconhecer o magnífico potencial de criatividade, reflexáo e inteligência que o mundo antigo nos legou ou tentou legar.

Às vezes sou tentado a pensar que a ablação da cultura clássica do ensino secundário (bem como outras ablaçóes) obedece ao desígnio dominante de criar exércitos de consumidores submissos, capazes de decifrar anúncios e de repetir os sound bites das manipulaçóes televisivas, mas privados dos termos de comparaçáo que permitam alguma distância crítica do mundo que nos é imposto. 
A minha admiração e respeito pelos que se dedicam ao estudo e ensino da cultura clássica, não se diferencia muito da consideração que se tem para com aquele quadrado que resiste corajosamente ao aniquilamento, não se deixa vencer e torna incerto o opressivo mesmismo dos nossos dias.

02-09-2012 $M d C$ 


\section{Tebas. A imagem literária do Tempo e da História em Mário de Carvalho}

Maria de Fátima Silva

Universidade de Coimbra 
(Página deixada propositadamente em branco) 
O VER TEBAS - Não curar de a procurar, pois é sita nas regiōes que quanto mais procuradas tanto menos encontradas. Mas ainda que em qualquer volta dos caminhos cimeiros se adregue vislumbrar ao longe, entre bruma cinzenta, suas muralhas gris, repletas de foscas armaduras, e se logre penetrar o interior dos muros, não se iluda homem sobre o ficar quite de cuidados, pois outros e bem pesarosos na altura lhe virão.

M. de Carvalho, O livro grande de Tebas, Navio e Mariana, 1121.

Esta é talvez a melhor síntese da proposta para que M. de Carvalho convida o seu leitor, de uma viagem através do Tempo e da História. Tebas remete para um destino - o seu passado ou a identidade de si mesmo - não escolhido mas que se impóe, para onde os passos do espírito se dirigem sem preconceitos, apenas como para algo que está implícito na ininterrupta cadeia humana. Mas se inevitável, esta é também uma marcha condenada à frustração. É a tradição que lhe serve de arranque e de guia. Foi ela a construtora, em linhas difusas, de uma cidadela, aquela onde toda a imaginação humana conflui como seu último ascendente. Ver Tebas seria, para cada um de nós, ver-se a si próprio, perceber o mundo onde, como homem, desde sempre existiu. Mas o que essa "pátria" oferece é uma imagem de "bruma", de distância e de esbatimento, longínqua demais para ser penetrada e conhecida. Vê-la é mais colher dúvidas que certezas.

Se aos antigos Gregos - para quem o nome de Tebas imediatamente remete - fosse perguntada a identidade de um guia capaz de os conduzir em idêntica aventura de devassar a História, a resposta não poderia ser senão esta: os poetas, em cuja tradição se filiaram os primeiros historiadores. São eles, uns e outros espíritos tocados pelas Musas e capazes de "palavras doces como o mel", os relatores, em tons diversos, da "biografia da Humanidade" 2 . E essa não se faz apenas de relatos concretos, deste ou

13 31996, Lisboa, Caminho.

2 Esta é uma expressão de Immerwahr, H. R. (1966), Form and thought in Herodotus. University of North Carolina: 4, a propósito do que chama "os aspectos não científicos da História". Sobre esta disciplina, o mesmo autor pode afirmar: "Não se trata apenas de uma construçáo racional baseada em testemunhos, mas, muito para além disso, de uma memória colectiva, em que o homem obtém autoconhecimento pela contemplação do passado". 
daquele episódio, com data, lugar e agentes específicos. Somados, os episódios que estabeleceram momentos definidos no fluir da História permitem deduzir traços gerais, chegar a Tebas como a Pátria de toda a Humanidade $(20)^{3}$ : "Era agora como se me houvesse uma pátria desimpedida, disponível, a que eu poderia chamar $a$ Pátria"'.

E para M. de Carvalho quem é esse sujeito, que protagoniza a grande odisseia de viajar pelo Tempo e pela História? É o autor que vive rodeado de livros, que, diariamente, se cerca de "rimas de infólios e resmas de velhos manuscritos tisnados", isolado, da luz crua que banha a realidade imediata, pelas paredes protectoras de uma qualquer biblioteca. Trata-se do amante da História, do navegador do passado, do explorador da sua própria identidade enquanto Homem. Para o seu projecto há um ponto de partida, o que um registo material estabelece como carta de marinharia sobre que constrói o seu roteiro. É preciso, antes de mais, criar com o passado uma familiaridade, para que então surja "o chamamento". Esta é a centelha - qual toque das Musas - que introduz a diferença essencial entre o que é o manusear diário, automático, profissional de testemunhos mais ou menos objectivos - "as minhas mil e tantas páginas de notas, os grossos volumes à margem glosados, os mil manuscritos encardidos, já meio decifrados e comentados", 19 -, que se abandonam, em demanda de uma nova etapa, que não se faz sem a primeira, mas sem a qual "livros, certidóes, documentos de papel, de pergaminho e de pedra" mais não são do que uma "rotina, que apenas perfazia um labor que encomendado me tinham".

Cumprido este prólogo, M. de Carvalho envereda por um percurso literário muito do seu gosto: o desmontar da normalidade em busca da liberdade de pensamento e de um projecto para uma vida autêntica 5 . Manusear documentos é, no caso concreto deste romance, o padrão de um trabalho mecanizado, imposto pela convenção social, dobrado ao nomos, a que urge

3 As páginas citadas, salvo outra identificação, remetem para a edição supracitada de O livro grande de Tebas.

4 Seria interessante recordar os três níveis que também Immerwahr, 1966: 6 estabelece para o entendimento de Heródoto sobre o que seja, na sua experiência, uma ainda incipiente história: factos, tradiçóes a respeito dos mesmos factos, e o trabalho historiográfico para interpretar essas tradiçôes. É dentro de um plano semelhante que M. de Carvalho se move nesta sua obra.

5 Este é um motivo literário tratado de uma forma sugestiva e insistente, por exemplo, nos diversos contos que constituem a colectânea $A$ inaudita guerra da Avenida Gago Coutinho (1992), Lisboa, Caminho, reimpr. ${ }^{9} 2006$ (veja-se, em particular, In excelsum, Ignotus Deus, Dies irae). 
escapar, sob pena de se ver liquidado o talento e aniquilada uma verdadeira capacidade especulativa, de que cada criatura humana é, de acordo com a sua physis, dotada. Não é este o sentido de História que o verdadeiro intelectual procura, recusando a atitude de um simples amanuense para assumir a de um verdadeiro criador. Para isso há que abandonar a História livresca, à procura de ver e sentir, verdadeiramente, o passado.

Foi com entusiasmo interior, sentindo-se rodeado de sorrisos de aplauso, que o aventureiro se lançou em imprevisível odisseia, em busca do que se pôde chamar "a total lembrança das origens de mim", um conglomerado de referências, sem espaço nem tempo determinados, que constitui a essência acumulada do pulsar universal. Ao mesmo tempo que o seu narrador se preparava para abandonar a biblioteca onde diariamente se afogava em pergaminhos e papéis, M. de Carvalho tomava a pena para construir uma metamorfose tấo do seu gosto e para que criou uma inconfundível estratégia de imagens; aquela que lhe permite produzir a transformaçáo de Realidade em História.

Partiu o viajante de aviáo, consumando um primeiro exercício de distanciamento: levantar os pés do solo, suspender-se no vazio, para deixar correr, sob os seus olhos, "o giro da terra" $(22)^{6}$. Perdidos os contactos físicos, o autor inicia o processo do apagar de uma realidade para se refugiar no neutro. Uma nuvem imensa que tudo cerca produz um primeiro efeito de desmontagem do espaço, "em que perderam sentido o cima e o baixo”. Em simultâneo, o espírito oculta-se sob o véu do sono, trazendo à neutralização do espaço um sugestivo anacronismo, a anulação do tempo (23): "Como quando alguém adormece, sendo muito novo, ao colo de uma velha avó, vestida de preto e de mãos ásperas, enquanto suave lavra o lume na lareira". Esbateram-se as cores, reduziram-se as luzes, silenciaram-se os sons e tudo se confundiu, como uma velha fotografia, numa "residual água-tinta de ténue verde-azeitona recobrindo todas as cores vivas". Para tudo culminar na "molificação" do aviấo, a diluição definitiva de uma realidade concreta a permitir o salto para o desconhecido.

6 Uma expressão paralela encontra-se em Fantasia para dois Coronéis e uma Piscina ( $\left.{ }^{3} 2004\right)$ Lisboa, Caminho, 34, onde M. de Carvalho atribui ao que aqui chama "avião" a designação feliz de "cronovelema", o "navio do Tempo": "Nós ... vamo-nos afastando, desliza Portugal, verdeja-nos por baixo, ora se afunda, e distinguimos lá ao largo a nítida orla do mar". Num texto onde se propóe "viajar" pela realidade portuguesa, utiliza estratégia comum à que, em $O$ livro grande de Tebas, lhe proporciona "um voo" sobre a realidade universal. 
Desconhecido que o não é totalmente, porque assenta em traves reconhecíveis, de uma natureza não livresca, que a fantasia ou, se quisermos, o mito, de há séculos vêm estruturando. É neste contexto que a palavra "Tebas" se impóe para designar " $a$ Pátria", a remissão última para um primeiro marco de civilização. Quebrado o vínculo com a realidade imediata, o primeiro arrimo a que o ousado viajante lança mão é o da palavra, insistente, obsessiva, veículo de uma ideia que lhe baila no espírito (36): "Uma palavra, Tebas entoa-me o cérebro, repetida, Tebas, repetida, repetida, Tebas". Do cérebro, a ideia como que salta para o papel (36): "Nem sei porquê, lancei em grandes letras nesta folha de papel o nome de uma cidade antiga: Tebas". Abeira-se o momento da criação literária, ideia e palavra associadas como por um impulso que escapa à vontade do criador, uma imposição mais forte, até então insuspeitada. O itinerário imenso da História e do Tempo ganhou um nome, arrancado ao inconsciente, arquivo de uma memória algum dia colhida. Tebas tem o poder anacrónico e universal de um símbolo, eleito por um acaso de entre outros possíveis; nem Tróia, nem Micenas, Atenas ou Argos; Tebas.

Atrás do nome, sobrevém um esboço de formas, primeiro indistinto, depois progressivamente consciencializado em linhas mais precisas. Trata-se do difícil exercício de regressar ao tempo antes do concreto, de erguer, como um padrão, a cidade de Tebas, que se vislumbra entre o autor e o papel, que "subvoa" (24) e paira nos ares. A criação aparece como um processo de suspensão, uma cumplicidade que se produz algures, num progressivo reconhecimento, entre o criador e o seu objecto. Se este é a História, prima pela fluidez, faz-se de memória e de futuro, é eterno na sua atemporalidade - "a história passada e futura de Tebas, desmemoriada ou inatingida de seus moradores", 39. Parte de um registo, retido nos documentos que se amontoam em bibliotecas e arquivos, incapazes por si de captar o pulsar das realidades que os ditaram. No seu convencionalismo nada contam, são meras enumeraçóes, inventários de contas que não retratam a verdadeira vida, excluídos "factos, acontecimentos, movimentos, impulsos, sentimentos, um rasgo de gente". Postos de lado os testemunhos, não de todo inúteis mas em si mesmos insuficientes, de que outros materiais dispóe o criador para repor os traços de uma verdade total e convincente? De um outro amontoado, não de mil e mil páginas, amareladas pelo tempo, mas de uma multiplicaçáo igualmente incontável de gestos, cada vez mais, com o passar dos anos, esbatidos, anónimos e frouxos, desfalcados de vitalidade e sentido. Haverá limites para este relato da memória, inspirado num eterno afrouxamento? 
Pensar Tebas torna-se então ainda mais difícil. Além de um corte exigido com a realidade imediata que coarcta a criatividade e a imaginaçáo, pensar Tebas é também o erguer de fronteiras, o interpor, no curso da História, de uma barragem, de modo a distinguir o antes e o depois. A ideia de passado começa no justo ponto onde se escreveu a palavra "último": de Tebas, a última flecha, a última porta, a última tenda, a derradeira ronda" (40). Vem então "o nevoeiro", a capa diluidora que cobre o tempo concreto, que, no seu imenso poder, mesmo se lento, subreptício - "baixinho, baixo, forte, alto" -, é impositivo, torna "sons" em "ecos", e um lugar definido em "vastíssima planura" sem contornos. Ao claro e real sucede-se o anónimo e o obscuro, massas informes, engrenagens e esferas, numa espécie de regresso ao caos primitivo. Do que foi civilização restam lamas, magmas, pedras e metais, uma espécie de amontoado, informe e em potência, dos elementos à altura da criação. A que poder obedece esta desconstrução não se sabe. Mas após a sua intervenção, resiste apenas a memória ou o sonho de uma realidade conhecida; e, para o espírito humano, o enigma: "Passar além das engrenagens, devassar uma outra esfera, náo creio que homem passe, e adregue contá-lo". Ultrapassar limites insuperáveis, desafiar o logos, na sua duplicidade dialéctica e retórica, é esta a máxima odisseia a desafiar o Homem.

Erguer Tebas tem de começar pela criação da "ideia", ainda geral, de cidade. Por isso, um primeiro passo funciona como a colecção de "materiais" que inevitavelmente se associam ao conceito. A terminologia urbanística domina num primeiro esboço (24): "Terraços, arcarias e praças e esplanadas, ruas estreitas e largas, agulhas de catedral, lances de zigurate (...), a massa do casario", filtrados por uma cortina opaca de nevoeiro, são como que um catálogo anacrónico e, por isso, universal, da imagem que qualquer ser humano, independentemente da sua origem ou cultura, tem de "cidade". Tâo impressionista quanto a própria imagem, a enumeração implica os traços genéricos de um paradigma: a dimensão ampla (expressa pela insistência no superlativo: "cidade imensíssima", "a maior cidade do mundo, a mais desconhecida dele"), a tonalidade arcaica que remete para um passado longínquo ("rocha cinza irregular toscamente lavrada"), o sentido de memória histórica que obedece à regra da continuidade ("lembra", "permanece, rolando lenta, lenta, com o tempo"). O leitor atento não deixará de registar o vazio humano, no que é por enquanto, partindo do caos primitivo, um simples jogo de formas. Para o narrador tratou-se de preparar uma Tebas em potência, a partir da "massa" essencial de que se constrói qualquer cidade. 
Reunidos materiais, o passo seguinte implica a selecção, de entre os elementos básicos, daqueles que podem convir à criação de uma Tebas determinada, "a minha Tebas" (32). Está dado o primeiro passo para uma actualização do arquétipo. Uma certa ordem de convençôes convive com uma nova disciplina, de modo a que a tradiçáo seja conscientemente assimilada. Como falar ou imaginar uma Tebas sem portas nem muralhas, na estrita obediência a um padrão que a Antiguidade consagrou? ${ }^{7}$ ? Como não poderia deixar de ser, "a minha Tebas" tem "cem torres e mil portas", acompanhando no exagero dos números a vastidáo da paisagem em que a vemos implantada. Com a definiçáo de um traçado mais nítido, a cidade imaginada passa a integrar vida e acção humana, aquela que melhor convém à mesma referência tradicional (32): "Anoto que há homens e que uma batalha qualquer ali se fere". Deixamos a amálgama de rochas toscas e de cinzas, para vislumbrar uma geografia humana. Da rendição que esta etapa representa por referência ao mito, dá M. de Carvalho testemunho: "Aceito Tebas, todos os seus recônditos".

A consciência de que uma tradição lhe subjaz leva o autor a ponderar sobre modelos. Que evocaçóes irrompem da palavra "Tebas"? Adiamos por um momento o projecto de uma recriação ou reescrita, para promover a revisão das Tebas de referência, com os seus atributos específicos. Pela negativa - "não será decerto a Tebas do Velho Egipto", "não é tampouco a Tebas erigida ao rés de montes agudos e pedrosos" -, as Tebas da tradiçáo são elencadas, como contributos determinantes na construção de uma lenda. Talvez a alusão ao "Velho Egipto" dê, à Tebas faraónica, a preferência, por antiguidade. Mas, mais do que os anos, são os traços específicos que lhe conferem identidade. Com "Tebas" competem, neste caso para maior precisão, nomes alternativos - "On, Tebas Luksor, Tebas Carnak" -, associados a uma localização agora exacta, "não longe do Vale dos Reis". São espirituais as suas primeiras insígnias, "os sacerdotes de Ámon” que, com os seus "cantos eternos", a fazem ressoar. As construçóes que a definem são as que convêm ao Egipto, casas cúbicas de adobe, fundidas sob uma tonalidade incontornável, "rósea e amarélea do sol". Domina-a, também ele marcado pela cor, "o braço moreno do faraó", um dos muitos que, durante quatro milénios, conduziu a força do Egipto, à frente de "legiốes e legióes e legióes". A Tebas ideal ganhou, por estes traços, uma identidade própria:

7 Naturalmente que textos como Sete contra Tebas de Ésquilo ou Fenícias de Eurípides, dedicados à dramatização do mito tebano, surgem como remissão inevitável para a arquitectura desta outra Tebas. 
sem deixar de ser bélica - ou não fosse ela Tebas -, passou a só fazer sentido em terras do Nilo.

Por essa mesma individualidade, a egípcia se opóe a outra Tebas famosa, erigida numa paisagem não menos característica, aquela em que as pedras que cobrem montes altaneiros se entrecruzam com "nesgas cintilantes de mar turquesa ao fundo". Esta é, certamente, a Tebas grega, nas faldas do Citéron, "cintada de granitos muros que evocam Antígona e Creonte e Édipo e a Esfinge e Píndaro e Alexandre" e todas as trágicas glórias que testemunhou. A paisagem é diferente, coberta de oliveiras, rodeada de pastagens, mas cenário, também ela, de prolongadas e penosas guerras. O próprio combate ganha, neste caso, uma natureza "homérica", a que Ésquilo e Eurípides deram eco. É possível desenhá-la, com escudos e o bronze das espadas, com gritos e súplicas de jovens, dados em sacrifício aos altares das divindades. Como não perceber, na generalidade do desenho, a evocação das vítimas da Esfinge e a grandeza de um jovem, Meneceu, filho de Creonte, que, para salvar Tebas da destruição, se imola em sacrifício voluntário, quando o fulgor das armas se comprimia em redor das muralhas da cidade ${ }^{8}$ ?

Em concorrência com as duas Tebas da tradição, uma africana e uma europeia, ao autor de $O$ livro grande de Tebas é permitida a "invençáo" de uma outra Tebas, asiática desta vez, implantada "no país de Sumer", a que acrescenta, sobre os traços de sempre, a magia oriental. Continua muralhada, prossegue como palco de cruzamento de multidóes, mas tem um acabamento exterior que lhe é exclusivo. Vibram nela, como emblema ímpar, "grifos de esmalte brilhante luzindo azuis em tijoleira vermelha, fiadas sem fim de três muralhas direitas", como reflexo de uma fulgurante Babilónia, Susa ou Ecbátana. As multidóes que a cruzam, "de barbados encaracolados homens de negócios", colhidas de um quadro de prosperidade e fortuna, fazem alarde das riquezas incontáveis do oriente, "passeando empenachados nos seus carros floridos pelas avenidas processionais”. É uma outra Tebas inexistente, mas fácil de inventar dentro de linhas que a tradição atesta.

8 Das tradições aqui aludidas dão testemunho textos como o Rei Édipo de Sófocles ou Fenícias de Eurípides. No primeiro mantém-se viva a tradição de um monstro devorador às portas de Tebas, a Esfinge, de que Édipo libertou a cidade (cf. Sófocles, Rei Édipo 3539, 390-398, 507-510); em Fenícias (944-952, 963 sqq.), trata-se com minúcia o tema do sacrifício voluntário de Meneceu, em nome da salvação da cidade. Por fim, o confronto dos dois filhos de Édipo - Etéocles e Polinices - e dos exércitos sob seu comando, pela posse do trono de Tebas, justifica a imagem da cidade invadida que serve de cenário à referida peça de Eurípides e a Sete contra Tebas de Ésquilo. 
A todas estas Tebas do passado M. de Carvalho sobrepóe, num movimento de ring composition, "a sua Tebas", para ele "concreta, ainda que inventada", que obtém pelo desmontar e reconstruir sucessivo do mito (34): "Nem tem sete nem cem portas, assinaladas pela lenda (...) Tem cem torres e mil portas que poderia contar e descrever, deambulando-lhe em torno das muralhas, numa vastíssima extensão". Esta é a Tebas entrevista do avião, a cidade do nowhere, da utopia, que foge a qualquer "território conhecido dos velhos compêndios". Situa-se em extremos nunca percorridos, isentos da marca de pegadas, "muito para lá das nuvens mais altas". Caracteriza-se pelo "não ser", como negativo das suas iguais nos traços que lhes são comuns: "Tebas em espessa bruma escondida, nem fria nem quente, nem seca nem húmida, tem cem torres altas, pesadas, escuras e quadradas, tem mil portas pequenas e gradas, esguias e largas, e vai cercada há muitos mil anos, por infindas legiôes de silentes, serenos, solenes guerreiros". É uma verdadeira imagem mítica, oculta sob o manto da fantasia, traçada num desenho único, construído por antinomias e sussurrado em hábeis aliteraçóes.

Feita a opção por um modelo, cabe ao autor satisfazer uma ânsia íntima e natural: a de tocar a sua Tebas, de a conhecer (104-105), de lhe palpar os vestígios e de a percorrer pela memória. Porque embora livre na sua criação, ele continua escravo de uma imagem, onde testemunho livresco e tradiçáo incorpórea se aliam.

Como promover esse contacto, antes de mais físico, com uma Tebas ideal? Sem dúvida pela visita, pela proximidade concreta, sentir e ver Tebas com mãos e olhos, "se viajantes lá houvera" (51-52). Como em todas as visitas aos vestígios do passado, seriam os monumentos, "os três maiores da cidade”, a concentrar a atenção; e porque relevantes marcos da memória, é junto deles que "a névoa é mais compacta". Seria este o tipo de projecto que um arqueólogo, o visitante natural do passado, seguiria, na peugada do que é esperável num campo de ruínas. Dos monumentos-padrão de uma Tebas para além das nuvens, a descrição só pode ser simbólica. Falta-lhes nitidez, tendem para uma forma redonda, regular, indistinta ("outro monumento é uma esfera colossal", "o terceiro é um enorme globo de granito"), a que estranhos acessórios se ajustaram ("de que emergem mil tubos (...) uns grossos como troncos, outros da finura de agulhas", "perfurado de mil orifícios, todos de desigual diâmetro, uns anchos, por onde cabe tronco de homem, outros finos da finura de cabelos"). Distingue-os uma variedade contraditória de elementos, numa espécie de amálgama de todas as possibilidades; o primeiro é mesmo dessa mistura o paradigma por excelência: "Um dos monumentos é um gigantesco poliedro irregular, de mil faces, e 
aspecto sempre diverso, revelado no circunvagar da bruma". A grandeza, associada ao emaranhado de linhas, torna-os únicos e inacessíveis a recuperar uma configuração exacta.

Será talvez de introduzir um ponto de ordem neste projecto de viajar pela História, para reconhecer que há, na cidade ideal, alvos diversos a privilegiar. Instala-se entâo uma dúvida metodológica (104-105), expressa em sucessivas interrogaçóes, sobre o plano a seguir para percorrer não só os seus três maiores monumentos, mas tudo o que constituiu a sua existência plena. "As tuas torres e os teus exércitos" são a ponta do fio, o primeiro passo da visita, ou náo é por eles que a vida em Tebas ganha sentido? A etapa seguinte implica insuflar, na legenda de fundo, um conteúdo. "Torres", como referências de defesa ou de ataque, trazem a menção de máquinas e cabos, enquanto "exércitos" impóem figuras circulantes e "repetidos, amiudados gestos, dos exércitos cercados, do exército de sítio". Num plano sucessivamente mais cerrado, o ângulo de perspectiva fecha-se progressivamente sobre "muros e casarios", como sobre homens com uma existência que vai para além dos simples exercícios do combate. Há famílias em Tebas, as torres escondem as casas, a guerra oculta um outro quotidiano. Mesmo a mole anónima do exército se humaniza com a imagem pessoal de "três silentes soldados que armam a balista, lhe fixam o pelouro, soltam a alavanca, olham, faces paradas, o desfechar do engenho". Homens e máquinas ganham um corpo, movem cada fibra, exibem uma face, ainda que sem ruído e sem pressa, como se vivos e maleáveis sob o nevoeiro bloqueador do Tempo. Tebas, porém, prepara ainda uma surpresa. Não é só o exterior dos atacantes, por contraste com o interior dos defensores, o que constitui os dois planos da sua existência. Intramuros, nos limites mais profundos da sua physis, há outra dicotomia: entre o plano íntimo das suas entranhas, onde se penetra a custo, abertas galerias, para um encontro inesperado com "os pequenos monstros sáurios que de olhos em brasa fitam", num regresso ao momento da sua fundação; por contraste com o da sua vida, onde "salóes, claustros, praças, câmaras, corredores, escadarias, janelas, fontanários, frontóes, portas, corredores, colunas", outrora barulhentos e banhados de luz, se quedam agora obscuros e silenciosos.

A penumbra da História começa por cobrir (85-86, 91-92) toda a cidade onde a sucessão alternante do dia e da noite se quebrou, vítima do próprio desgaste. A luz, ainda que escassa, a envolver a memória não vem do sol; nem sombras há, o que pressupunha o reflexo dos raios do astro-rei. Dessa luz difusa sobressaem náo mais do que "volumes, formas e contornos, figuras e feiçōes", numa harmonia essencial entre "a natureza das pedras 
e da bruma”, vestígios e memória aliados contra a escuridão de um esquecimento que tudo apague. Também para a "bruma" qualquer explicação científica é inútil. Às interrogações que suscita - "e que bruma é esta?”, 91 -, que são uma tentativa de perceber a História, não responde a descrição de um fenómeno físico; não se trata de um vapor proveniente de evaporação, porque não há, em volta dessa Tebas que paira nas alturas, qualquer curso de água que a justifique. Nem tão pouco partículas de pó, porque não é arenoso o terreno que lhe cinta as muralhas. Logo, "com todas as reservas de uma primeira explicação" (92), há que reconhecer para esta bruma uma outra causa, a que a funde com as próprias pedras, Tempo e Obscuridade como duas circunstâncias indissociáveis. Sobre pedras, gentes e guerreiros, esta névoa funciona de moldura, que cerca uma tela e lhe estabelece os limites; porque em volta de Tebas nada há, ela existe por si mesma nos seus contornos brumosos.

Este é, em linhas gerais, o retrato de uma Tebas que M. de Carvalho passa a construir em pormenor. Em primeiro lugar, Tebas será sempre uma cidade cercada, envolta em aparatoso arsenal de guerra, povoada de sitiantes e sitiados. Fazer-lhe o desenho, como se de uma pintura da História se tratasse, é imobilizá-la, na suspensão e no silêncio. Mas atentemos agora no particular. Sobre as muralhas alinham-se, "pensativos", os defensores de Tebas, a observar a massa do inimigo que ameaça. O texto português regressa ao modelo literário da teichoskopia - ou "observação do cimo das muralhas" - que, desde Homero e com eco patente em Eurípides, se tornou tradicional. Porque se trata apenas de uma descrição inconsequente nos resultados - "grupos de arqueiros, nas ameias, tomam flechas de grandes cestos de vimes, prendem-nas entre os dedos, ajustam-nas à crina tensa, vergam o arco com esforço e apontam, calculando com vagar a trajectória do dardo", 39 - os gestos têm de ser precisos, plásticos mas nunca consumados. Literatura e pintura confluem como duas modalidades de mimesis, no retomar implícito de uma velha teoria ${ }^{10}$.

Mas a vigilância de Tebas produz-se também de forma mais recatada, mais íntima, nas tendas que servem de abrigo à guarda (120-121). Mais

9 Cf. Ilíada 3. 166-242, em que Helena aponta a Príamo, do cimo das muralhas de Tróia, os guerreiros destacados do exército grego; e Eurípides, Fenícias 88-195, em que, acompanhada pelo Pedagogo, Antígona, sobre os muros de Tebas, olha o exército argivo, que se aliou a seu irmão Polinices na reivindicação do seu direito ao trono paterno. Sobre este tema e sua execução literária, vide Silva, M. F. (2005), Ensaios sobre Eurípides. Lisboa, Cotovia: 288-289, 293-300.

10 Cf. Aristóteles, Poética $1447^{\mathrm{a}}$ 18-23, 1448b 4-19. 
do que avistarem o campo inimigo, aí os homens controlam "entradas e saídas". Quando o visitante se concentra sobre o sentido dessas tendas surge a interrogação: "Quem habita as tendas redondas ali plantadas aquando do primordial assédio da Tebas cinzenta?" Ninguém parece existir no que não passa de um "cenário de vigilância", mais um elemento indispensável num contexto de guerra. $\mathrm{O}$ mesmo vazio dá asas à imaginação e permite vislumbrar não o que existe, mas o que lá poderia ter existido: um espaço para a ponderação de tácticas militares, um armazém de equipamentos, uma acomodação de guerreiros, vivos ou mortos, ou simples portas de saída para além de Tebas, que a um só tempo marcam e desfazem limites. Sáo como um ponto / umbigo do mundo, ao mesmo tempo um local preciso, fixo, mas de onde se parte através de um olhar lançado sobre o além ${ }^{11}$. Será este olhar um simples gesto de vigia, que a guerra exige, ou um efectivo "olhar além", daqueles que procuram penetrar, mais do que a realidade imediata, o verdadeiro desconhecido e o sentido pleno de tudo o que os desafia?

Não menos expressiva de um subtexto inspirador, que encontra nos já citados Homero, Ésquilo e Eurípides uma fonte irrecusável, é a "descrição do guerreiro", com os seus trajos e armas convencionais ${ }^{12}$. Mais do que concretizar ou particularizar, este é um elemento que, paradoxalmente, irmana atacantes e defensores. Em pouco diferem os agentes da guerra, são, acima de tudo, "combatentes". Pertencem-lhes, por isso, elmos, túnicas, saios, lorigas, escudos, arcos e flechas, sandálias ou borzeguins, que, numa evidente mistura de sabor anacrónico, confluem no fluxo ininterrupto da História da guerra. Sobrepóem-se-lhes os eternos emblemas decorativos ("em todos os elmos, e em grande diversidade, há incrustaçôes várias de trabalhos retorcidos que representam flores e frutos e plantas, entrelaçados com grande engenho"; "no couro, foram gravados motivos geométricos, em fiadas já meio-sumidas e nunca com cor, em que o triângulo é figura prevalente, mas também o semicírculo e o trapézio", 56), de onde é patente a mescla de motivos, desde os que se inspiram numa natureza vigorosa - e alheia à destruição da guerra -, até ao neutro primitivo das formas geométricas.

11 Como o vigia famoso que Ésquilo, Agamémnon 1 sqq., plantou sobre o telhado do palácio de Micenas, numa longa espera de um sinal que anunciasse o destino do seu senhor e seus homens, partidos à conquista de Tróia, também M. de Carvalho recria "o guerreiro, sentado ao alto de uma fraga, (...), pernas pendendo, vestidas de grevas, figura meio curvada, de costas voltadas a Tebas", 122. Ao serviço da casa onde se imobiliza, mas de certa forma ausente dela, todo o impulso do seu olhar escrutina o desconhecido.

12 Sobre esta tradição na épica e na tragédia grega, aplicada aos paradigmas de Tróia e Tebas, vide M. F. Silva, Ensaios sobre Euripides, 343-368 e bibliografia aí citada. 
Também eles contribuem para a noção de "sem tempo", que associa a elaboraçấo de traços retorcidos com a limpidez de esquemas elementares. E, num aprofundar voluntário do anacronismo que reina numa viagem pelo Tempo, o narrador cria, com a evocaçáo do tradicional, um choque de contemporaneidade. De um sírio sem idade (56-57), a quem interroga sobre a ideia que faz de Tebas, a de Tirésias, obtém a mais inusitada das respostas: "Tebas? É lá em cima, na Grécia. Agora tem caminho-de-ferro, um entroncamento. Faz-se muito comércio". O metal que antes enchia a Tebas guerreira de estranhos brilhos sobrevive nos caminhos do progresso e da modernidade, carris e comboios penetrando a cidade noutro tempo.

$\mathrm{Na}$ sua policromia, os guerreiros que povoam as colinas em volta de Tebas constituem um todo retalhado em batalhóes, que nos devolvem ao modelo de um tradicional catálogo ${ }^{13}$. Reunindo as diversas tradiçóes, M. de Carvalho reparte-se entre a imagem das tropas em repouso ou activas na preparação do combate (67-68). Os homens diluídos na massa, fixos, parados, são a anónima maioria; enquanto as actividades próprias de um exército são executadas, em simétrico anonimato, em grupo. Aos primeiros caracteriza-os a força de um insistente "não" ("não patrulha, não move máquinas de guerra, não investe as muralhas, não roja projécteis”), aos segundos a dinâmica do gesto ("aprestam ... pousam ... fincam ... cortam ... retiram ... apontam ... desferem"). São, no total, uma mole imensa, com competências definidas: há archeiros, besteiros, infantes, cavaleiros. Percebe-se-lhes os movimentos, sinal de uma previsível arremetida; tudo se passa, porém, numa penumbra por trás da qual o número e a acção se diluem e as cores se desbotam, dominada por um silêncio, que abafou qualquer "pequenino som de retinir ou zumbido, ou sopro".

Da massa anónima, qualquer esforço para nomear um chefe seria vão (48-49). Os nomes de referência, ao comando da luta fratricida de que a Tebas mítica foi cenário - Etéocles e Polinices, os filhos de Édipo, diante de garbosos companheiros -, sumiram-se; a hierarquia do comando perdeu sentido, apagou-se tal como a nitidez de linhas e sons. Cada ordem obedece apenas a um modelo pré-estabelecido - "a ninguém obedecem os militares

13 Ilíada 2. 484-760, a par de outras ocorrências significativas no mesmo poema (4. 223-241, 771 sqq., 816 sqq., 16. 168 sqq.), é deste modelo épico um exemplo famoso, na descrição que faz das tropas sitiantes e sitiadas na guerra de Tróia; Eurípides, no párodo de Ifigénia em Áulide (164-302), regressa ao motivo com uma plasticidade impressionante, desenhando o exército grego, em repouso, na expectativa da partida para Tróia. Sobre a matéria, vide Silva 2005: 344-350; Beye, C. R. (1964), "Homeric battle narrative and catalogues", HSCh 68: 345-373. 
de Tebas, porque ordens nunca são proferidas, antes pré-ordenados estarão desde os primórdios os gestos de batalha". Do mito de referência, a efemeridade da memória náo consente mais do que um anonimato geral, sem menção dos seus actores inevitáveis.

Depois da uniformização de atacantes e atacados, o combate ordena-se, na sua imperiosa dicotomia, em volta de um símbolo forte: as portas de Tebas. É nelas que se concentra o ataque, substituída uma visão abrangente por um alvo concreto. Os golpes que a tradição salvaguardou, no entanto, não deixam na robustez aparente "dos batentes chapeados" marca concreta, apesar do vigor agressivo das armas de investida, "pesadíssimos aríetes cabeça de carneiro de altos troncos petrificados", e da violência dos golpes "a dar e dar (...) desde há muitos mil mil anos para cá" (77-78). Na sua fragilidade alada, são as palavras que perduram, livres de repetirem os vestígios de uma lenda que, essa sim, se não apaga. De sete portas e dos seus sete atacantes se cresce para cem, um número que amplia a tradiçáo. Ésquilo, nos Sete contra Tebas, pintou este episódio, onde os escudos são um elemento central de memória ${ }^{14}$. Presentes ainda nesta outra versão, os escudos são apenas de "enodoado vime", sem a decoração que lhes dava voz e fazia deles intérpretes do sentido das vontades em confronto.

Se Ésquilo pode ser uma remissão para a simbologia dos escudos no desenho literário da guerra, é-o também para o retrato de uma população desarmada sob a fúria dos combates, os simples "habitantes de Tebas" (39-40). Partilham do imobilismo e do silêncio que os rodeia, vivem numa anarquia colectiva arquivada pelo Tempo. São "mansos nos gestos", monótonos nos movimentos, "vão e vêm, e passam e perpassam em sossego, ou em sossego ficam, naquele seu apagado modo de estar de branda populaçáo sem tino". Exprimem-se em gestos ritmados, obedecem à simultaneidade coreográfica de um coro de tragédia. Falta sentido, projecto, objectivo à sua vida. Parecem autómatos, subservientes a uma força superior. Um flash valoriza uma componente precisa, as mulheres, carpideiras sem prantos nem bramidos. São aquelas Tebanas que Ésquilo moveu, como um coro impressionante, no ambiente de conflito que é o dos Sete. São as mesmas que um dia se confrontaram com um ímpeto militar, que introduziram nas

14 É célebre o longo episódio dos "sete pares de discursos", em Sete 375-684, em que Etéocles é levado, pela descrição dos sete atacantes de Tebas, e em particular dos escudos que carregam, símbolo da personalidade e motivaçóes de cada um dos seus possuidores, a montar a estratégia mais adequada à defesa da cidade. Com esta cena, Ésquilo revela ao seu público o significado profundo de um combate, cujo desfecho é evidente mesmo antes do começo. 
ordens de combate prantos de aflição, atentas aos ruídos que, vindos do exterior, anunciavam a presença inimiga e o fim iminente da sua segurança. À distância do Tempo elas são apenas vultos sem som, que evocam, mesmo assim, horas fatais no destino da cidade.

Quase estulto seria procurar ainda em Tebas um sinal de vida, partir da guerra, sua insígnia natural, à procura dos dias felizes. Talvez viciado pela monotonia em que fora criado, antes de se atrever à louca aventura de a abandonar, o narrador, mergulhado nas brumas de Tebas, empreende também a busca da sua rotina. É emblemático o espaço onde a recupera; no coração da cidade, onde o clamor da guerra mal chega, está o estádio, símbolo máximo da existência colectiva, robusto na altura dos seus muros, lisos no exterior, mas a esconderem, dentro, uma bancada de pedra - capaz de oferecer ao cidadáo acolhimento, náo o da intimidade das casas, mas o do convívio social. Trata-se de uma espécie de cidade dentro da cidade. "Um espigão alto", a spina, divide em duas a pista; mas mais do que ordenar o espaço do certame, onde carros, gladiadores e feras um dia fizeram vibrar multidóes, essa coluna é, no momento, o marco da História, erguido para identificar o lugar e permitir a reconstituiçâo do que se apagou.

Enquanto tacteia as pedras e percorre, com passo cauteloso, a insegurança do terreno, o visitante reproduz, em imaginação, as horas de glória de que o estádio é feito. Basta-lhe reconstituir um único dos cidadãos de Tebas ali sentado, "no sétimo degrau da quarta bancada", cotovelos nos joelhos, cabeça entre as mãos espalmadas. Estende o olhar ao longe, até à tribuna de honra onde se instalariam os juízes, simples olhar imaginado, mas que dá nobreza e majestade ao recinto.

Esta imaterialidade, que faz de tudo em Tebas uma realidade abstracta, causa mal-estar no visitante, aquele que a penetra como se materialmente não existisse, sem deixar rasto. Apesar do seu empenho em se aproximar, será sempre o intruso, "estranho àquelas terras, àquelas gentes e àquela guerra tão sem tempo" (94). Se é verdade que as portas da cidade se lhe franquearam espontaneamente e lhe permitiram o percurso de tudo o que protegiam, é também certo que a sua passagem não ficou "nunca registada na memória”, como que cativa de um geral anonimato. A História é afinal caminho aberto, sem portas nem barreiras, mas brumoso, arriscado e impenetrável.

De uma visão de Tebas à superfície, $M$. de Carvalho convida-nos a um olhar mais penetrante sobre as profundezas que se escondem, só acessíveis por "corredores intermináveis (...) que se prolongam pelo ventre da terra e não acabam em parte nenhuma" (90). Somos levados para além dos con- 
tornos nevoentos de uma Tebas construída, à procura dos tempos, mais remotos ainda, da sua origem. No âmago da terra, sobrevivem os "monstros", não já o dragáo que o mito fixara como guardiáo de um solo virgem onde Cadmo, guiado por mão divina, quis implantar os alicerces da civilizaçãa ${ }^{15}$; lá reinam, no "sem tempo" do romance, "animais escamosos e gordos, de frio sangue, hirtos, inteiriços, único movimento pressentido a respiração de bafo gelado, olham fixamente com os seus olhos parados" (90; cf. 38). Impregna-os ainda um sabor mágico, na "lucífera cor" que emitem, saída das esmeraldas, rubis e rosáceas que os recamam. São estas as cores únicas que resistem em Tebas, as que registam, em tons fulgurantes, a sua origem. Este é, para o "viandeiro da hipótese" - a persistente curiosidade humana -, "o limite da afoiteza possível"; "deterá sua marcha tacteante ao pressentir esses seres primordiais (...) e se volverá logo à bruma dos ares, inquietado por dentro, triste da sua impotência de passar além”. Com a descida ao âmago da terra e das suas origens, o homem atingiu as franjas da própria imaginaçáo. Defrontou-se aí com o absoluto, viu-se diante da fronteira que o separa, como ser efémero, do conhecimento oculto no infinito (90): "A imensa sageza contida em tais olhares fê-lo pequenino e desencorajou-o de aprofundar a marcha”.

Erguida, em pensamento, a sua Tebas, importa ao autor assumir o papel de um velho escriba do Egipto e ser capaz de introduzir, no fluxo do registo histórico ou da ficção literária, o seu testemunho (127-133). Porque, ao lado da História, existe essa outra cadeia eterna da palavra que lhe dá expressão. Entre as duas é necessária compatibilidade, para que a harmonia seja efectiva. E uma pergunta mais se perfila neste longo questionário sobre Tempo e História: a que soube o texto, que consultamos à distância, aos seus contemporâneos? Uma verdade fica clara: a do sentir, em cada época diverso, de cantos, fórmulas e rituais. Perante esta certeza, resta a dificuldade de, pela literatura, fazer vibrar emoçóes a propósito de uma remota Tebas; enorme é o desafio de arrancar das brumas do passado vibraçóes convincentes e actuantes.

15 Esta é a explicação mitológica para justificar o sangue vertido num terreno, na hora em que à barbárie se substituía a civilização. Mas do dragão eliminado, nas suas mais remotas origens, resultou para a Tebas mítica uma maldição, que só o sangue dos seus filhos poderia redimir. O destino anunciado para Tebas exprimia-se por uma violência, fatal e duradoira. Cf. Ésquilo, Sete contra Tebas 69-75; Eurípides, Fenícias 638-675, 931-941. É curiosa a vaga correspondência entre Fenícias 660, na menção “às pupilas vigilantes” do dragão, e o desenho vistoso que M. de Carvalho aprofunda do motivo. 
Que durabilidade têm os gestos dos guerreiros ou os quadros de guerra? Que relação temporal separa a guerra ao vivo da sua imagem, traçada pela História? $\mathrm{Ou}$, mais obscuro ainda, como recuar aos dias, puramente lendários, que assistiram à fundação de Tebas e em que a cidade viveu a alegria da paz e da pujança, embora erigida sobre um lastro de sangue a condicionar-lhe o destino?

Estas são perguntas que denunciam a incontornável precaridade humana, e aquela necessidade que rende o Homem à busca de um princípio e de um fim para tudo o que o rodeia. A finitude humana é avessa à noção de eternidade, não dispensa a ideia do antes e do depois.

Por essa mesma natureza se pode apor, sobre as perplexidades quanto à origem e passado de Tebas, igual questão sobre o seu futuro. Até quando poderá perdurar, neste inevitável empalidecimento de uma realidade, o sentido de História. 


\section{Mário de Carvalho e a reflexáo metaficcional sobre o futuro do romance}

José Cândido de Oliveira Martins

Universidade Católica Portuguesa 
(Página deixada propositadamente em branco) 


\section{Rumos de uma cartografia possível}

É compreensivelmente complexa qualquer tentativa de cartografar as principais tendências do romance ou da ficção portuguesa contemporânea. Para contrariar ou moderar esta ousadia, é frequente argumentar-se com a falta de distanciamento crítico suficiente; mas ainda com a multiplicidade de orientaçóes estéticas e de percursos singulares de escrita dos autores atuais no campo da narrativa.

Contudo, estas e outras razóes não nos devem inibir de esboçar - aqui assumidamente muito de relance e a pretexto do percurso de Mário de Carvalho (Lisboa, 1944) - um sucinto mapeamento de algumas dessas tendências da escrita ficcional. Para além dessa ressalva, impóe-se outra também de natureza metodológica, embora sem exagerado rigor demarcativo - a ficçáo contemporânea de que falamos estende-se grosso modo entre duas balizas cronológicas: a revolução de abril de 1974 e a atualidade, após a superação do século e do milénio, tendo já suscitado alguns diferenciados balanços críticos (cf. Arnaut 2002; Reis 2005).

Ora, nestas últimas décadas, ainda bem próximas de nós leitores e críticos - e sem pretensôes de nenhum tipo de revisão abarcante ou exaustiva -, é possível rastrearem-se várias tendências encetadas ou aprofundadas pela ficção portuguesa contemporânea, com destaque para alguns traços ou caminhos que, por diversas razões, também não são alheios à natureza e orientaçôes da poética ficcional de Mário de Carvalho e, concretamente, ao delimitado tópico que nos interessa de momento:

i) A revitalização da História, em registos bastante diferenciados, desde a evocação mais respeitadora, "ortodoxa" e algo epigonal (revivescência do romance histórico tradicional), até à reinterpretação alegóri$\mathrm{ca}$, revisionista e parodicamente desmitificadora, tal como analisado criticamente por Maria de Fátima Marinho (2010), quando reflete sobre o tópico da identidade perdida.

ii) Correlacionadamente, a questionação de uma certa ideia de "identidade nacional", particularmente da problematização do imaginário nacional e do ontológico "modo de ser português", sem esquecer o papel de certas narrativas fundadoras ou identitárias, de acordo com conhecida tese de Eduardo Lourenço (1982).

iii) A tendência acentuadamente pós-moderna para a autorreflexão metaficcional, em que a escrita reflete sobre si mesma, sobre os seus processos e convençóes, afastando-se, de modo crítico, de certo 
paradigma clássico de escrita ficcional (com destaque para a problematização do género romanesco, sua poética e fronteiras com outros géneros) - metafiç̧ão no sentido genérico de narrativa cujas variadas manifestaçóes de autorreflexividade a tornam consciente do seu próprio processo narrativo, quer a nível diegético, quer linguístico, em modalidades de maior ou menor visibilidade, metaficção manifesta ou dissimulada (cf. Hutcheon 1984: 23 e 31). Este é o ponto que nos interessa focar seguidamente.

iv) A construção de discursos literários de índole assumidamente intertextual e interdiscursiva, através da incorporação de outros textos, discursos e géneros, numa atitude por vezes lúdica, num "palimpsesto saturado" no caso de Mário de Carvalho (cf. Silvestre 1998: 213). Essa densidade intertextual (urdida de citações disfarçadas, referências, alusōes, montagens, etc.) mostra-se um tecido naturalmente desafiadora da competência literária do leitor; ao mesmo tempo, é decisiva para a construção da pluralidade ou densidade dos sentidos textuais; e apresenta-se ainda contaminada por uma dose variável de humor, sobretudo ao convocar e aproximar autores, referências e saberes aparentemente díspares e em quantidade tâo notória.

v) Interligadamente, a assunção da paródia enquanto metadiscurso recorrente, apostado na inversão irónica de géneros e de textos, de códigos e de convençóes. Entendendo-se aqui paródia como um metadiscurso, intrinsecamente dialógico e imitativo, que opera sobretudo uma inversão irónica, com distanciamento crítico, de um outro discurso literário (sob a forma de texto, género, convenção ou código literários), cuja amplitude do ethos se estende ao cómico mais ou menos ridicularizador até à homenagem disfarçada ou respeitosa (cf. Rose 1979; Hutcheon 1985).

Estas e outras tendências marcantes da recente evolução do género romanesco demonstram a polivalência e a complexidade da escrita do romance, genologicamente recetivo às mais diversas transformaçóes; e, sobretudo, aberto a uma crescente autorreflexividade, que não exclui processos de autoironia e de autoparódia. Curiosamente, já na segunda metade do séc. Xx, na conhecida reação diante da obra de François Mauriac, o crítico Jean-Paul Sartre insistia na ideia de que era necessário superar o esgotado modelo clássico de romance; e Marthe Robert acrescentará que o único caminho era através da desmontagem irónica (cf. Raimond 1989: 25). Aliás, sabemos bem como a inovadora teoria literária dos formalistas russos 
(I. Tynianov, V. Chklovski ou B. Tomachevski) acentuou a funcionalidade reguladora da paródia ao nível das transformaçóes operadas no sistema literário.

Com efeito, no caso particular de que nos ocupamos, a ostensiva presença do narrador na ficção de Mário de Carvalho assume múltiplas formas e objetivos - da sátira sobre a sociedade contemporânea à visão estética sobre o próprio fazer literário. Enquanto forma aberta, tradicionalmente definida pelas ideias de totalização simbólica, singularidade e universalidade (cf. Lukács 1989), o romance do autor português apresenta-se assim como género em assumida mutação, de natureza não só evolutiva e de propósitos autocríticos; mas também como um género proteiforme, assumindo ou deixando-se contaminar por outros discursos e géneros, do ensaio à poesia, passando pela crónica. Curiosamente, é o próprio escritor a declarar que "o romance está em aberto" - como escreveu no Jornal de Letras em 2 de agosto e de 1995 -, no sentido em que, de facto, não possui uma poética coerciva e limitadora da evolução dos seus códigos compositivos. Por outras palavras, o romance contemporâneo, de autores como Mário de Carvalho, transporta uma matriz de inventividade e de autorregeneração, incompatível com qualquer ideia de uma poética fixa e intemporal.

Consabidamente, a partir da segunda metade do séc. $\mathrm{xx}$, os ficcionistas mostram-se muito mais conscientes de questóes teóricas implicadas no processo ficcional. Nesta tendência marcante para explicitar o fazer literário, avultam as manifestaçôes de frequente e obsidiante autorreflexividade. $\mathrm{Na}$ escrita de autores tão diversos como Jorge Luís Borges, Vladimir Nabokov, John Barth, Ítalo Calvino ou Umberto Eco, mas também José Saramago ou Mário de Carvalho - para só citarmos alguns ficcionistas -, desenvolve-se uma continuada e renovadora teoria da ficção a partir da prática da ficção, numa permanente tensão entre sistema (langue) e prática literária (parole), à luz duma perspetiva semiótica de matriz saussureana: "Each metafictional novel self-consciously sets its individual parole against the langue (the codes and conventions) of novel tradition" (Waugh 2003: 2).

Para o ponto que nos ocupa, mostra-se crucial uma aproximaçáo teórico-crítica entre pós-modernismo e metaficção, em que radica todo um programa ficcional de autorreflexão do género romanesco. Da referida Patricia Waugh, o conceito de metafiç̧ão é assim definido: "Metafiction is a term given to fictional writing which self-consciously and systematically draws attention to its status as an artefact in order to pose questions about the relationship between fiction and reality" (Waugh 2003: 11). Já outros estudiosos do pós-modernismo, como Linda Hutcheon (1989: 48), optam 
por, entre outras conceituaçóes, definir a narrativa metaficcional como "representation of writing as representation". Também o teórico inglês David Lodge, também ele autor de diversos romances metaficcionais, descreve a ficção pós-moderna através das manifestações de metaficção.

Esta propensão para reflexão metaficcional deve inserir-se numa postura crítico-filosófica bem mais ampla, de autoconsciência hermenêutica e cognoscitiva sobre o modo como o nosso conhecimento do mundo é mediado pela linguagem. Isso é particularmente visível em diversos meta-discursos que, a nível social e cultural, dentro e fora das ciências humanas, problematizam epistemologicamente as condiçóes e a natureza do conhecimento humano. Esta atitude inquiridora e até cética faz sentido num tempo de grande aceleração da História, de grandes mutações, mas também de enorme incerteza e instabilidade, onde tudo se questiona - das certezas científicas aos valores, das ideologias às religióes.

Similar preocupação reflexiva e problematizante se tem vindo a verificar latamente no domínio dos estudos literários - a obra literária como facto de linguagem, v.g. - e, em particular, na questão central da construção dos mundos ficcionais do género romanesco. $\mathrm{O}$ tradicional paradigma de romance realista (com suas técnicas narrativas, códigos estéticos, pressupostos ideológicos e respetiva mundividência), já não se adequa à nova realidade atual e aos valores culturais dominantes, como demonstrado aliás por sucessivas metamorfoses do romance moderno e contemporâneo, logo a partir das primeiras décadas do séc. Xx, desde M. Proust, J. Joyce ou F. Kafka, passando pelo nouveau roman francês, entre outras marcantes tendências renovadoras do género (cf. Albérès 1972).

Neste quadro, a orientação metaficcional desnuda o valor coercivo dos géneros e o peso das convençóes literárias tradicionais, acentuando a sua pretensa saturação ou esgotamento. Com esta postura, o sistema literário patenteia capacidades críticas de autorregulação, nomeadamente ao nível da escrita literária e da evolução de um género em particular, como o romance, debatendo-se aí as forças contraditórias de preservação e de rutura, da evolução do sistema e da sua manutenção e impositividade; ou seja, numa tensão entre a normatividade do sistema (código literário romanesco) e a pressão para um processo evolutivo do género. É neste âmbito que se deve entender a crescente consciência da dimensão de artifício das convençóes e dos processos romanescos e da necessidade da sua questionação e evolução.

Como se constata, o problema de fundo extravasa a teoria do romance ou da ficção, mas conhece aí particular acuidade. Trata-se da questáo 
central da representação, inerente ao processo literário e ficcional, enquanto construção assente na linguagem e no seu poder de efabulação. Afinal, numa perspectiva semiótico-comunicacional, a realidade (sistema social) e a linguagem (sistema linguístico) precedem o texto literário e romanesco, bem como os seus códigos (sistema literário). Está em causa, hoje talvez de uma forma mais intensa, a axial problematização das relaçôes entre as palavras e as coisas, variante moderna da velha dicotomia res/uerba; isto é, a capacidade de representação da realidade através da literatura e sobretudo do romance, como estudado crítica e diacronicamente por Erich Auerbach (1976), entre tantos outros estudiosos.

Concretizemos, como se interroga, implícita e metaficionalmente, a própria ficção de Mário de Carvalho: faz sentido que numa realidade contemporânea tão acelerada e mutável, com reflexos ao nível do sistema literário, o romance continue a usar as conceçóes de outrora? A crise das ideologias, das grandes narrativas e da cultura, como assinalado por reconhecidos ensaístas, acaba por ter reflexos nas ideias da impositividade de um cânone ou da autoridade coerciva poética de um género e respetivo arquitexto; e, desse modo, originando e contaminando, irremediavelmente, a própria ideia de crise e correspondente desejo de autorrenovação do romance, da sua natureza e dos seus limites.

Daí também deriva a constatação de o romance moderno e contemporâneo assumir muitas vezes a feição de anti-romance, implodindo, irónica e parodicamente, velhos paradigmas e processos; ao mesmo tempo que configura um padrão reflexivo de ficção sobre a ficção (metaficção), fenómeno vasto a que o ensaísta Carlos Ceia prefere chamar de ficcionismo (cf. Ceia 2007: 13, 121 e ss.).

\section{Mecânica da ficção: metaficção e paródia}

É um lugar-comum da teoria literária e da crítica atual reconhecer que o romance contemporâneo se pensa auto-reflexivamente, num permanente processo evolutivo. Contudo, apesar da relativa novidade do termo "metaficção" - e respetivo afấ teorizador -, a sua prática é quase tão antiga quanto a história do romance, desde Miguel de Cervantes e Laurence Sterne até romance modernista. Aliás, como sustentado por diversos teóricos e historiadores do romance, a atitude metaficcional mostra-se, em certo sentido, congenial ao romance enquanto género sem lei, isto é, sem uma poética clássica normativa, dotada de rigidez e impositividade dos 
seus códigos, à imagem de outros géneros. Como salientado por Patrícia Waugh (2003: 67), na própria natureza ou matriz do género romanesco e, consequentemente, na sua evolução história, está inscrita a tendência para a autorreflexão metalinguística e metaficcional:

The novel, always inherently self-conscious, always inherently provisional in its process relativizing language through continuous assimilation of discourses, has now and again to stop and examine the process, to see where it is going, to find out what it is.

Como sugerido, a essência do romance mostra-se incompreensível sem esta atitude auto-reflexa, até como forma crítica de contrariar a exaustão do género. É justamente neste âmbito da natureza mais livre do género romanesco que se compreende, ao longo da sua história, as relaçóes fecundas com outros géneros e formas, valorizando-se assim não só um contínuo processo de autoquestionamento, mas um modo peculiar de enriquecedoras relaçóes dialógicas. Por isso, o teorizador russo M. Bakhtine (1970; 1981: 39) insistiu tanto no dialogismo do romance, enquanto género dinamicamente aberto à relação com outros discursos e enunciados. Assim sendo, como espaço de interaçáo verbal e discursiva, não surpreende que o romance potencie uma reflexão metaficcional no contexto desta abertura dialógica; e esse procedimento se constitua como caminho de desconstrução de certo paradigma tradicional, ao mesmo tempo que procura caminhos de superação, como no que designou de romance polifónico.

É neste contexto problematizador, rapidamente introduzido, que devemos inserir a singular criação do ficcionista Mário de Carvalho, autor de várias obras dispersas por diversos géneros ficcionais, do conto à novela e ao romance, passando pelo teatro. Na sua produção romanesca - secundarizemos a narrativa curta, para o tema em análise -, manifestam-se algumas das tendências antes sugeridas, em maior ou menor grau, encontrando-se aí modulaçôes muito pessoais, de acordo com uma estilística e uma poética ficcional ímpares.

Como sugerido, destaca-se especialmente a natureza metaficcional das narrativas de Mário de Carvalho. Parafraseando o crítico James Wood (2010), atentemos então na maneira como funciona a mecânica da ficção de Mário de Carvalho (how fiction works); isto é, ilustremos a maneira como uma alargada e constante atitude metaficional perpassa de modo permanente a sua escrita, norteada náo apenas por propósitos lúdicos-verbais, mas sobretudo críticos e revisionistas, atitude valorizadora de uma certa 
maneira de conceber o "fazer literário". Por outras palavras, a escrita de Mário de Carvalho ostenta uma aguda autoconsciencialização do processo narrativo ao nível da própria urdidura ficcional. Volta-se reflexivamente para si própria, questionando os princípios da sua poética possível, através de uma assinalável variedade de procedimentos.

Com efeito, a leitura crítica de um selecionado corpus de Mário de Carvalho - Era bom que trocássemos umas ideias sobre o assunto (1995); Fantasia para dois coronéis e uma piscina (2003); e $A$ arte de morrer longe (2010), que naturalmente poderia ser mais alargado, mesmo temporalmente - permite-nos, por si só, indagar como o escritor desnuda alguns artifícios e convençóes do romance ou da ficçáo tradicional, numa postura assumidamente metaficcional e parodística, sem se perder numa postura de mero entretenimento ou jogo verbal.

Bem ao contrário, o escritor demonstra plena consciência de que, ao longo das últimas décadas, foram vários os ficcionistas que desmontaram, ironicamente e a vários níveis, uma certa tradição ou paradigma de "romance clássico", com os seus códigos de referência (da velha omnisciência narrativa à indagação psicológica, passando por determinada estruturação discursiva). Definitivamente, partindo da velha e proverbial afirmação de Paul Valéry - sublinhada pela poética surrealista de André Breton -, já não é mais possível escrever um romance em cujo incipit se declare, em detalhismo informativo: "A marquesa saiu às 5 horas"...

Ao mesmo tempo, diante de um espírito inconformado e renovador bem assumido, como é o de Mário de Carvalho, não é recomendável ler a sua ficção fora de uma inteligente cultura do humor, que se serve da ironia e da paródia metaficcionais para desmontar o esgotamento de certos processos. Numa conceção assumidamente lúdica da estrutura narrativa, densamente intertextual, as vozes narrativas controladoras destas três ficções de Mário de Carvalho desconstroem, de modo constante e paródico, a formalidade de certos protocolos de leitura ou convençóes narrativas. Neste sentido, a singularidade da escrita de Mário de Carvalho nestes romances confirma a tese de Carlos Ceia (2007: 220):

A paródia é a forma privilegiada do exercício poético-ficcional da autorreflexividade. (...) Não sendo um recurso exclusivo de uma época, está suficientemente documentada no espaço que se convencionou chamar literatura pós-moderna para nos permitir distinguir a paródia também como paradigma desta época. A condiçáo de autorreflexividade é apenas uma forma de realização da paródia e não a sua definição final (...). 
O tom estilístico da obra de Mário de Carvalho é logo dado pela inesperada e provocatória "Advertência" autoral, em epígrafe de Era bom que trocássemos umas ideias sobre o assunto, geradora de um humorado horizonte de expectativa: "Este livro contém particularidades irritantes para os mais acostumados. Ainda mais para os menos. Tem caricaturas. Humores. E alguns anacolutos" (Carvalho 1995: 9). Em outros livros de Mário de Carvalho, as epígrafes e os incipits cumprem função semelhante, investindo claramente no sentido destas inscriçóes peritextuais; e sobretudo estimulando provocatória e humoradamente o leitor inteligente, de modo a nunca o deixar indiferente. Simultaneamente, a notável destreza e o grande à vontade do autor no manejo da escrita e dos mecanismos de ficção está indiciado, ao nível da enunciação narrativa, em procedimentos como o referido. Porém, alarga-se a muitos outros, num jogo irónico e paródico constante, desafiando a sagacidade cúmplice de um leitor ativo.

Esta atitude lúdica e metaficcional demonstra-se especialmente numa diversificada quantidade de procedimentos. Revela-se, desde logo, na frustração do arranque da narrativa ou da sua linear organização discursiva (mais dada a analepses, elipses e sumários) - quando o leitor, mais preso a esquemas e modelos tradicionais, poderia esperar certo desenvolvimento convencional da diegese, é frequentemente surpreendido com outra estrutura ou com interrupções inesperadas. Satirizando certos cursos académicos de escrita criativa, o narrador náo hesita em desnudar o processo produtivo, argumentando que o relato não avança por causa da sua concessão às divagaçôes: "E porque já vamos na página dezoito, em atraso sobre o momento em que os teóricos da escrita criativa obrigam ao início da ação, vejo-me obrigado a deixar para depois estas desinteressantes e algo eruditas consideraçóes (...) (Carvalho 1985: 18).

$\mathrm{O}$ alargado programa metaficcional do escritor manifesta-se também nas conscientes descoincidências entre o tempo da diegese e o tempo do discurso: "Por um instante fugaz - tanto que leva mais tempo a contar que a acontecer - tentou recordar (...)" (Carvalho 1985: 27), refere autor-reflexivamente o narrador a propósito do pensamento evocativo de uma personagem; ou ainda na intromissáo inesperada de certas personagens, que irrompem em cena com motivaçóes mais ou menos credíveis. Com essa postura, desnudam-se processos cruciais como o da organização da diegese ao nível do discurso narrativo; ou ainda os códigos de ilusão romanesca que presidem à composição das dramatis personae.

A mesma atitude irónica e metaficcional é visível nos repetidos procedimentos de questionação da verosimilhança e dos seus processos; 
bem como da denúncia do abuso de certos "expedientes literários" (Carvalho 1995: 33), como o famigerado "deus ex machina"- de ascendência clássica e teatral, este expediente é abundantemente parodiado pela escrita ficcional de Mário de Carvalho (cf. 2003: 222; 2010: 44, 66), como tópico exemplar de outros artifícios da narrativa tradicional - gato escondido com o rabo de fora... Em A Arte de Morrer Longe, o narrador mostra-se ironicamente perentório: "Abaixo os expedientes para introduzir uma narração à conta dum adormecimento" (Carvalho 2010: 34). Aliquando bonus dormitat Homerus... A fluência da narrativa deve prescindir desses artifícios que já não enganam nenhum leitor, pois estáo gastos de tanto uso.

O afã metaficcional do escritor está patente também na reflexão expressa sobre o uso de certa opção ao nível focalização narrativa - "Um narrador omnisciente tem as suas vantagens" (Carvalho 1995: 35), assevera a voz narrativa de Era bom que trocássemos umas ideias sobre o assunto; ou na surpresa do narrador ao ver-se surpreendido com as falas que uma das suas personagens lhe dirige, em Fantasia para dois coronéis e uma piscina. A discussão da modalidade de focalização da voz narrativa e, correlacionadamente, do grau de presença e de omnisciência do narrador, constituem tópicos recorrentes desta indagaçáo autocrítica sobre os limites da ficção.

A reflexão metaficcional alarga-se à desconstrução do próprio estatuto do narrador, autoritário demiurgo no seu Olimpo (e se anuncia mesmo no texto como "autor totalitário"), mas ciente da sua fragilidade ontológica, com o narrador a afirmar de uma personagem - "Joel existe, eu não" -, lamenta-se nestes termos o narrador de Era bom que trocássemos umas ideias sobre o assunto, entre diversos exemplos.

Como seria de esperar, a desmontagem metaficcional da escrita de Mário de Carvalho estende-se às irónicas referências a certa cultura literária nem sempre bem assimilada e aos respetivos discursos teórico-críticos da moda - a propósito da impreparação de uma jovem jornalista, interroga-se o narrador: "Onde é que Eduarda tinha aprendido estas coisas todas? Blasé, interface, intertextualidade, frontispício, new age, paralaxe, pórtico, e mais um ror de palavras finais? Numa vasta Universidade que só funciona à noite e que tem plúrimos departamentos nos bares do Bairro alto e na Avenida 24 de Julho" (Carvalho 1995: 58).

Ainda nesta filosofia literária auto-reflexiva e proactivamente inovadora, ganha especial acuidade a viva teatralização da narrativa, em particular dos diálogos, muito ricos em reflexóes de teor metaliterário e metaficcional - procedimento que alterna com as reflexóes contidas no 
discurso das vozes narrativas -, e que tanto podem referenciar a Poética de Aristóteles e a Arte Poética de Horácio, como investir a organização do discurso narrativo de vários procedimentos cénicos, numa assinalável contaminação genológica.

Entre tantos outros processos narrativos objeto de auto-questionaçáo metaficcional - e esta ilustraçáo está bem longe de ser exaustiva -, o leitor pode reparar na justificação sobre a sobriedade dos traços psicológicos das personagens, a pretexto da reação de uma personagem (a jovem jornalista Eduarda Galvão), comentando o narrador: "A literatura é uma coisa muito séria, onde não entre o zapping. Eduarda tem um destino a cumprir e eu arranjarei maneira de a integrar na história em que tenha de fazer sair um deus duma máquina. Por agora, traço-a a pinceladas rápidas, de zarcão, despachadamente, não me atardo nos pormenores, prescindo das espessuras". E logo adiante, de forma mais explícita: "Eu náo queria entrar em pormenores psicológicos, porque tenho pressa, e prometi não aprofundar em excesso esta figura" (Carvalho 1995: 59, 61). A voz narrativa desnuda assim, diante do leitor, com ironia q.b., o seu programa de escrita.

Estes e outros procedimentos de índole ostensivamente metaficcional - típicos de uma narrativa narcisistica (cf. Hutcheon 1984: 23 ss.), nas modalidades de forma manifesta ("overt") ou dissimulada ("covert"), a nível ora linguístico, ora diegético - repetem-se e ampliam-se nas obras narrativas do referido corpus de Mário de Carvalho. Com destaque para algumas das mais recentes - Fantasia para dois coronéis e uma piscina e A Arte de Morrer Longe -, o gosto de contar histórias mostra-se indissociável de uma certa desestabilização vigiada e irónica da narrativa, insistindo-se na autorreflexão e desconstrução da estrutura da narração.

Ainda neste espírito autorreflexivo da escrita ficcional de Mário de Carvalho, de forte tessitura intertextual, frequentemente contaminado por um registo irónico e paródico, merece realce a divagação de matriz horaciana (Arte Poética), em torno dos "desvios" e "imaginaçóes" que perturbam a economia, a verosimilhança e a unidade da narrativa (Carvalho 2003: 15-16). Aliás, não deixa de ser irónico e até algo paradoxal que num "género sem lei” como o romance, Mário de Carvalho convoque amiudadas vezes a auctoritas da poética de Aristóteles ou de Horácio.

Também sobressai a variedade do intertexto das mais recentes narrativas, ao contrapor irónica e carnavalescamente - como ocorre frequentemente na escrita metaficcional - os autores canónicos a outros fenómenos sociológicos, desde os autores de best sellers da cultura de massas (de 
Ponson du Terrail a Paulo Coelho), incluindo a BD, a música pimba ou mesmo o lixo televisivo. Sem esquecer, neste piscar-de-olho irónico e até cáustico, as referências intertextuais e metaliterários a outros autores e obras, das ambíguas remissões a autores canónicos, como Eça de Queirós, Camilo Castelo Branco ou mesmo José Saramago, e sobretudo as farpas dirigidas a certos fenómenos de massas ou subprodutos de consumo kitsch, como a menção a "um livro adocicado do senhor Paulo Coelho" (Carvalho 2003: 33).

Como sugerido, nesta escrita metaficcional destaca-se o recurso à paródia como forma de ridicularização de certa gravitas literária, impeditiva sobretudo de todos os modos de institucionalizaçáo de formas e da natural exaustâo processos. A par dessa tão frequente associação da paródia à metaficcionalidade (cf. Macedo 2008: 73-81) na escrita de Mário de Carvalho, manifesta-se também a reiterada intenção de desorientar ambígua e provocatoriamente o leitor, ora desfazendo as fronteiras entre a referencialidade e a ficção; ora insistindo na ilusão dos mundos possiveis esteticamente criados, na sua variada tipologia (cf. Albaladejo 1986: 75-79; 1992: 49-52), sempre revelando formas de autoconsciência verbal e ficcional.

Pelo afirmado, conscientes da sua dimensão de artefacto literário, através de variadíssimos processos de auto-reflexividade constante, mesmo que em regime lúdico e paródico, estas narrativas de Mário de Carvalho instauram uma metaficcionalidade explícita e crescente, assumidamente configuradora de uma renovada ideia de romance ou de narrativa adequada aos tempos atuais. Por isso, não deveria constituir um desafio muito exigente às capacidades hermenêuticas do "experiente" e "sagaz" leitor; mas antes ser motivo de fruição estética e continuado gozo irónico e intelectual; e ainda constituir apelo constante à sua cooperação interpretativa e atitude crítico-reflexiva. Os vários narradores de Mário de Carvalho convidam, de certo modo, o leitor a pensar - com essas vozes narrativas - o destino ou o rumo do romance atual; continue esse género narrativo a chamar-se assim (romance) ou de outra maneira (uma nova designação para um género renovado), de modo a não confundir-se com um paradigma romanesco já inquestionavelmente ultrapassado.

Nesta atitude metaficcional e humorada, também ela bem típica de um espírito pós-moderno (e até pós-colonial), a escrita ficcional de Mário de Carvalho exorciza ainda, pelo humor e pela paródia constantes, certas fantasias e fantasmas do imaginário português. Por isso, não faltam referências ou alusóes, disseminadas pelas três narrativas referidas, a obras tão diversas como: i) a epopeia de Luís Camóes, com os seus contornos ideológicos e 
os ecos interpretativos até aos dias de hoje; ii) a História Trágico-Maritima e alguns dos seus mais conhecidos relatos de naufrágios, sem esquecer a sua forte simbólica anti-épica; iii) e José Saramago, assinalável fenómeno de popularidade e de receção, autor não isento de preconceitos e de controvérsias.

Deste modo, o imaginário cultural coletivo é constituído objeto da mesma alargada consciência crítica, frequentemente através do valor patrimonial e identitário de algumas das suas obras literárias. Por exemplo, num discurso irónica e corrosivamente contrário a certa retórica oficial do "nacional portuguesismo" - utilizadora abusiva de Os Lusíadas numa leitura redutoramente patriótico-nacionalista -, um reconhecível espírito anti-épico atravessa, por ex., Fantasia para Dois Coronéis e uma Piscina. É sobretudo visível desde a invocação inicial à Musa, passando pelas referências à História Trágico-Marítima e ao popular naufrágio de Sepúlveda (Carvalho 2003: 95, 141, 146); encerrando com uma irónica e subversiva paráfrase camoniana, exprimindo assim o cáustico olhar sobre a decadência do país: "Nô mais, ficção, nô mais! (...) Há emenda para este país?" (Carvalho 2003: 227).

Como se constata, nesta continuada e cativante tendência para metaficção paródica, Mário de Carvalho também desconstrói - numa dimensão também assumidamente interdiscursiva, e não meramente intertextual ou arquitextual - a seriedade anacrónica de mitos, valores, figuras ou narrativas identitárias, tradicionalmente configuradores de certa tradição, memória ou identidade coletiva. Isso é particularmente visível em determinada retórica oficiosa de engrandecimento do passado histórico e imperial da grande nação portuguesa - desde as épocas remotas da nossa História, passando pela época dos Descobrimentos e das tragédias dos naufrágios, até à "patriazinha iletrada" e incivilizada dos nossos dias, metaforizada na remota vila de Grudemil, num retrato desencantado do Portugal contemporâneo (cf. Martins 2011).

Esta vocação latamente metaficcional das narrativas de Mário de Carvalho assenta, como adiantando já, numa fecunda relação com a paródia e com procedimentos que lhe estâo habitualmente associados, da ironia à intertextualidade. A paródia metaficcional mostra-se assim um processo autocrítico de natureza especular: revelar os velhos processos como forma de distanciamento e de superação. Assim se compreendem processos como a densidade de uma repetida intertextualidade irónica; ou a frequente intromissão do narrador (ativo homo ludens) e a ênfase colocada em intervençóes sobre a ficcionalidade do ato de narrar, num con- 
tinuado e consciente processo de desocultação (cf. Waugh 2003: 63 e ss.). O objetivo é o de desestabilizar certas conceçóes através do estratagema de jogo ficcional:

Fictional play also reevaluates the tradicional procedures of communication and allows release from established patterns. Metafiction explicitly examines the relation of these procedures within the novel to procedures outside it, ensuring the survival through adaptability of the novel itself (Waugh 2003: 36).

Como seria de esperar, o leitor (e a sua enciclopédia) é habitualmente implicado neste jogo narrativo, sendo-lhe atribuído um papel bastante ativo e cúmplice, como participante indispensável no processo autocrítico da reflexão metaficcional (lector in fabula). O leitor é desafiado a seguir os desafios da voz narrativa e a ter uma palavra através de consciência crítica sobre os procedimentos literários que permitem a construçáo ficcional. Por conseguinte, a autorreflexividade narrativa mostra-se indissociável de um leitor cooperante, que adquira consciência dos procedimentos que conduzem ao artefacto narrativo:

Any text that draws the reader's attention to its processo of construction by frustrating his ou her conventional expectations of meaning and closure problematizes more or less explicity tha ways in which narrative codes (...) artificially construct apparently 'real' and imaginary worlds in the terms of particular ideologies while presenting these as transparently 'natural' and 'eternal' (Waugh 2003: 22)

Enfim, o leitor do discurso metaficcional perdeu a velha ilusão em paradigmas narrativos de outros tempos. A poética romanesca tradicional insistia, de diversos modos, na "verdade da ficção"; opostamente, a escrita metaficcional contemporânea desvenda a "ilusão da ficção", acentuando a ideia de artifício literário. Simplificadamente, são dois modos de entender o processo literário da representaçáo em que assenta a criação ficcional.

Numa palavra, a metaficção surge-nos como uma forma maior ou uma das faces mais visíveis do pós-modernismo literário atual; e no caso das narrativas referidas de Mário de Carvalho, são exemplos de ficçóes conscientes do seu próprio próprio processo, de forma manifesta, quer no 
plano linguístico, quer no diegético. Essa auto-reflexividade vai ao ponto de propor uma nova forma ou género narrativo.

\section{Cronovelema, futuro da ficção?}

Com efeito, a culminar este continuado pensamento metaficcional que estrutura especialmente a escrita do referido corpus de Mário de Carvalho, o leitor é confrontado com uma proposta algo ousada, mas repetida e consistente - ora implícita e difusa, ora assumida e expressa - de um novo modelo ficcional de romance (ou narrativa sua sucedânea). Aponta-se e particulariza-se, de forma ilustrada e argumentada, um modelo de narrativa liberto de peias e constriçóes impositivas, mais adequado ao mundo e ao ritmo contemporâneos, pondo diretamente em causa um determinado arquitexto do género romanesco e respetivos códigos tradicionais.

Constatamos, na sequência do afirmado antes e numa lógica recriadora, como a metatextualidade e a metaficção exploram os limites dos códigos estéticos e mesmo dos saberes estabelecidos, testando a incerteza e a porosidade das fronteiras entre géneros e discursos; e transformando assim a metaficção num projeto com uma componente política, como salientado por Jacques Sohier (in Lepaludier, 2002: 41).

Ou seja, nas referidas criações Mário de Carvalho assiste-se à configuração de um tipo singular de narrativa, chegando-se mesmo a concretizar, expressa e metaficcionalmente, a definição de uma nova forma de narrar. Numa palavra, no cerne da auto-reflexão deste autor, somos confrontados com a recodificação de um género narrativo. Deste modo, a desconstrução metaficcional a que assistimos tem o fecundo propósito de inaugurar uma nova forma literária, à luz de uma paródia dialética alicerçada na relação esgotamento/renovação.

Não embarcando em demagógicas e estéreis proclamaçôes da "morte do romance" (ou morte da própria literatura), este escritor mostra consciência das sucessivas metamorfoses do romance como género em permanente evolução e constante processo de autoavaliação crítica. Ao mesmo tempo, tem plena noção do que se pode aproveitar de uma rica história libertária, subversiva e metaficcional da escrita romanesca, de Cervantes a Sterne, entre outros autores das suas afinidades eletivas.

Definitivamente, nesta conceção vitalmente dinâmica e evolutiva do género, o romance ou a narrativa de hoje não podem imitar rigidamente um modelo passado (do paradigma balzaquiano à derivação realista ou 
naturalista, com diversas evoluçóes posteriores); nem sequer ficar-se pelos revolucionários modernizadores do romance a partir das primeiras décadas do séc. xx (Virgínia Woolf, James Joyce, Franz Kafka, etc.); nem ainda pelas sucessivas tendências novecentistas, da lost generation americana ao nouveau roman francês, do romance politicamente engagée à narrativa existencialista ou psicologista.

Enquanto "novo rico" ou "género sem lei" (lawless), o romance é por isso mesmo mais vocacionado e permeável para assumir sucessivas formas e discursos, exigidos pelo espírito do tempo em cada época, numa espécie de paráfrase livre do conhecido pensamento de Stendhal - com as devidas matizaçóes e reservas, não será o romance o espelho que se transporta ao longo do caminho da História? Auscultando as pulsóes do seu tempo, cada época molda um tipo diferenciado de romance, metamorfoseando anteriores conceçôes, num processo de renovação imparável (cf. Raimond 1989).

Afinal, parafraseando J. Ortega y Gasset, como pode alhear-se a ficção de hoje do homem atual e das suas circunstâncias? Porém, perante esta formulação, logo se ergue a argumentação conhecida: náo é essa uma conceção redutoramente sociológica e mimética? Não necessariamente, antes forma artística de representação com os naturais mecanismos efabuladores da imaginação criadora. Retomando a mesma perigosa imagem, o romance será o espelho transfigurador, assente na construção de universos ficcionais, podendo variar significativamente os índices, os cambiantes e os procedimentos usados na refração da matéria espelhada.

Qualquer semelhança entre esses mundos possíveis e a realidade circundante não é mera coincidência... Mesmo quando a representação literária (mimesis) é ironicamente questionada, com o narrador a desnudar-se perante o leitor, confessando que não conseguiu inventar melhor; ou quando, de modo igualmente jocoso, reflete sobre os seus intentos em matéria de verosimilhança. Mesmo nestes casos, manifesta-se o desejo de contar uma história dotada de determinado efeito de real, onde sobressai a centralidade da auto-consciente entidade enunciadora do discurso narrativo (cf. Waugh 2003: 2). No entanto, a funcionalidade reguladora e reflexiva da voz do narrador intrusivo, ironicamente assumida e provocatória, ao mesmo tempo que denuncia a exaustáo de velhos processos, também se distancia de alguns procedimentos demasiado experimentais:

"Daqui a bocado preciso de dirigir uma pequena interpelação ao Joel Strosse, e, até lá, não convém que fique nada por elucidar. Se não fosse abusar, até usava alíneas e limitava-me a substantivos. Mas como 
costumo ficar incomodado das habilidades modernaças, armadas ao pingarelho, com que a minha concisão poderia confundir-se, forço-me, por disciplina, a debitar texto, embora escasso. Onde é que eu ia?" (Carvalho 1995: 112).

Assim, não possuindo nem uma poética prescritiva, nem um cânone rígido, como outros géneros multisseculares, o romance mostra-se um género em devir, uma forma aberta, para recorrermos à conhecida conceituação de G. Lukács. Ora, também para Mário de Carvalho, nos tempos atuais se impóe justamente uma reflexáo em torno dos novos rumos e natureza genológica do romance. Para este autor, na sua postura obsessivamente metaficiconal, é urgente refletir sobre uma poética ou uma prática de escrita mais adequadas às novas circunstâncias. Ao mesmo tempo, implicitamente, o autor mostra consciência da relativa novidade da sua proposta, uma vez que ela se insere no âmbito de uma tradição ficcional que remonta, pelo menos, aos sécs. XVIII e XIX.

Observe-se, aliás, que essas liberdade e inventividade genológicas em Mário de Carvalho são já visíveis a partir da obra seminal $O$ Grande livro de Tebas navio e Mariana (1982); mas tornam-se particularmente notórias em obras mais recentes como as destacadas antes. Ou seja, esse percurso indagador de novos rumos é particularmente notório em Era Bom que trocássemos umas ideias sobre o assunto (1995). Curiosamente, nesta narrativa, a discussão crítico-ideológica em torno do estado da "esquerda pós-moderna", em finais do séc. xx e no contexto português, parece-nos de algum modo análoga à própria indagação crítico-paródica sobre o novo rumo da ficçáo contemporânea. A denúncia dos processos anacrónicos de adesão e de funcionamento do PCP também pode ser lida, até certo ponto, como símile da necessidade de superaçáo das velhas formas e processos romanescos. Recorrendo à linguagem de influentes ensaístas como George Steiner, somos testemunhas da falência de grandes narrativas, num denominador comum de crise instalada.

Afinal de contas, a dois níveis distintos (político e estético-literário), a sociedade e a cultura pós-modernas impóem uma rutura com os modelos do passado, exigindo uma tentativa de superação. As grandes metanarrativas ocidentais, sejam elas ideológicas, religiosas ou culturais, entraram também elas em crise manifesta e irremediável. Como realçado pelo pensamento pós-moderno, essas narrativas fundadoras já não se mostram detentoras da verdade, nem são capazes de explicar o mundo; por isso, se voltam para si próprias num processo de autoquestionamento. Como salientado no conhecido pensamento mais radical de Jean Baudrillard, os poderes e 
os discursos falam atualmente de si próprios, através da simulação, para contornar a sua agonia real.

Em Mário de Carvalho, esse desejo de refundação da escrita ficcional ora reabilita certa lição ou presença dos clássicos intertextualmente convocados (de Fernão Lopes a Eça de Queirós, sem esquecer certa tradição anglo-americana); ora vitupera todas as formas de epigonismo estético, bem como os usos chocantemente empobrecedores e bárbaros da língua portuguesa, enquanto sistema modelizante primário e fundacional do próprio sistema literário. Essa aguda e consciência da herança intertextual (tradiçâo literária) é assumida sem ansiedades edipianas ou "angústia da influência" (Carvalho 2010: 110), antes expressa de forma irónica, lúdica e sadia: "A quem escreve, faz sombra esta barreira constante, eriçada de farpas, daquilo que outros mais expeditos ou temporãos escreveram antes" (Carvalho 1995: 50). Noutro passo da mesma obra, a voz narrativa reincide em manifestaçóes de autorreflexividade sobre o mesmo tópico dos débitos literários, de reconhecimento sempre tão difícil por parte dos escritores: "Estes pensamentos não são meus que náo quero ferir suscetibilidades de criadores de dobermans, mas eram mais ou menos descontando a parte do Ray Bradbury - os de Joel Strosse" (Carvalho 1995: 259).

Já a censura contra os desmandos e os atropelos da língua constitui uma sátira reiterada e violenta, apresentando-se a voz narrativa como atento vigilante dos condenáveis atropelos linguísticos - “(...) nós, viajantes do vocabulário, da semântica”. São sobretudo narradores bem conscientes do trabalho sobre a língua exigido pela criação literária, quase evocando implicitamente a velha lição dos clássicos (labor et lima): “Um dia, leitor, hei de contar as ânsias e tormentos com que se vai martelando esta artesania da escrita" (Carvalho 2003: 19, 216). Depreende-se daqui uma conceção modelar e vigilantemente crítica do romance - ou dos seus sucedâneos em matéria de língua.

Porém, é sobretudo em dois romances mais recentes que Mário de Carvalho expressamente, e através das vozes intrusivas e controladoras, de preocupaçóes metaficcionais, enuncia melhor a sua conceção de um novo rosto para a escrita ficcional, quando propóe o neologismo e define o conceito de cronovelema - género compósito e híbrido, que agrega as convençóes de outros géneros, desde a agilidade narrativa e reflexiva da crónica, até ao caráter efabulador da novela, sem esquecer ainda nessa súmula renovadora a contençáo do conto, a hibridez do poema em prosa e ainda, last but not least, o dinamismo narrativo próprio do cinema. 
A natureza deste género híbrido torna-se visível, por exemplo, na singular abordagem do tempo, na dinâmica estruturação do discurso narrativo (ordo naturalis / ordo artificialis), nas mudanças de ponto de vista, na alternância de planos (do plano geral para o pormenor do close-up e vice-versa, v.g.), nas inesperadas alteraçóes de níveis narrativos (metalepses frequentes), na sobriedade da análise psicológica, entre outras opções.

Em Fantasia para Dois Coronéis e uma Piscina, depois de problematizar em registo metaficional vários aspetos da estrutura narrativa; e até de citar, parafraseadamente, a Poética de Aristóteles como texto fundacional da teorizaçáo da narrativa - para definir o que entende por "entrecho" e "açáo", bem como a "elevação da linguagem" face à "verdade dos factos" (Carvalho 2003: 16 e 54) -, a voz narrativa justifica-se perante o leitor, a fim de lhe explicitar uma nova forma de narrativa, com sua poética e ritmos próprios: "Este [texto] em que flanamos - chamemos-lhe cronovelema - propóe-se narrar. E isso demanda o seu tempo e os seus tempos" (Carvalho 2003: 34 , itálico nosso). Sob o pretexto de um balanço ou acerto de contas com o passado (com o empenhamento político-partidário e com a Revolução dos Cravos), a narrativa configura-se, de facto, como retrato satírico de um certo Portugal contemporâneo e vulgar, porque inculto e alienado.

Em entrevista, o escritor definirá cronovelema como uma narrativa híbrida, composta por diferentes géneros - a novela, a crónica, o cinema e mesmo a poesia (cf. Martins, 2003: 12). Nesta proposta renovadora, fica patente o jogo a que o narrador submete, de modo ostensivo, a linguagem, os géneros e as convençóes estético-literárias.

Finalmente, em A Arte de Morrer Longe (2010), o retrato satírico da vida conjugal de Arnaldo e Bárbara, e da ameaça de divórcio de um jovem casal desavindo - alegoria demolidora de certo vazio de valores que corrói a sociedade atual, minando as relaçóes interpessoais - corre a par da proposta explícita de um novo modelo de escrita ficcional, o novo género literário designado de cronovelema, "invençâo de certo escritor que amanhã nomearei” (Carvalho 2010: 99), afirma o narrador, que assim convoca o autor para o universo ficcional. Já anteriormente o mesmo narrador se tinha referido à "verdade contida numa das últimas linhas de diálogo deste cronovelema” (Carvalho 2010: 71). Aliás, não deixa de ser significativo que A Arte de Morrer Longe seja a primeira narrativa de Mário de Carvalho a assumir, de modo explícito e peritextual (com a liberdade que assiste ao autor), a designação genológica de cronovelema, inscrita na própria capa da obra. 
Três corolários breves, a terminar: em primeiro lugar, estas e outras narrativas parecem corresponder a uma acentuada evolução (ou inflexão) da escrita ficcional de Mário de Carvalho, observável a partir da década de 1990 - no sentido de um certo abandono (temporário?) da revisitação histórica ou de universos mais fantasiosos, em favor de um realismo quotidiano, atraído por uma contemporaneidade decadente, desencadeadora da postura crítica adotada pelo escritor, num estilo manifestamente tocado pelas cores irónicas do pícaro, do satírico desencanto ou da paródia carnavalizadora, à sombra de uma ética da vigilância crítica (cf. Martins, s.d.).

Lendo estes e outros textos ficcionais de Mário de Carvalho, encontra-se facilmente um denominador temático comum. Assim, não parece ser possível ficar indiferente às manifestaçóes da pseudo-cultura e ao oportunismo descarado de autores, editores e produtores culturais; mas também às manifestaçóes de baixa cultura, ao jornalismo incompetente, aos profissionais oportunistas e impreparados, à anacrónica forma de militância política, à corrupçấo interiorizada e impune; e ainda ao desinteresse pela causa pública, aos vícios congeniais da mentalidade coletiva, enfim, à "descidadania da lusitana gente" (Carvalho 2003: 84) - sociedade de aparências e simulacros (Jean Baudrillard), que promove a ignorância e a alarvidade, desde a literatura à vida profissional e social. Ora, a proposta conceção de renovado romance ou de cronovelema não é indiferente a este contexto cultural, podendo agir crítica e agudamente sobre ele. Perante esta nova realidade e cosmovisão do séc. XXI, não é possível continuar a contar uma história com um paradigma romanesco de tempos pretéritos, divorciado da realidade atual.

Em segundo lugar, pode equacionar-se outra questão: a reiterada representação, tantas vezes em registo caricatural, de um presente alienado e bárbaro, tal como descrita nestas e em outras narrativas do autor, representa a nostalgia de tempos pretéritos? À imagem de certa ideologia da geração de 70 e de Eça de Queirós, a decadência do Portugal contemporâneo contrasta com a dimensão heroica do Portugal de outrora, sobretudo com a nação aventureira celebrada por Camóes? A escrita de Mário de Carvalho recusa retóricas ultrapassadas, visóes idealizadas de um certo Portugal ou insustentáveis conceçóes patrioteiras; antes, sem saudosismos serôdios, se detém num retrato desventurado do "teatro do quotidiano", dizendo o desencanto português de hoje. 
Por outras palavras, cremos que a escrita de Mário de Carvalho, inovadora, prazenteira e cáustica, náo se identifica com o referido tipo de nostalgia ou contraponto ideológico fácil (oposição passado/presente, e portanto longe da esgotada tópica do laudator temporis acti). Antes constrói a representação de um certo Portugal presente à luz de um ideário de fundo humanista e ético, através de desencantadas "meditaçóes morais" (Silvestre 1998) sobre o destino coletivo: "Há emenda para este país?" - interroga-se no explicit de um dos romances (Carvalho 2003: 227).

Assim, a escalpelizada realidade circundante, várias décadas após a revolução de 1974, está bem longe de corresponder aos ideais emancipatórios e aos padróes de equilibrado desenvolvimento que se esperavam de uma sociedade democrática e evoluída. É neste quadro disfórico que se entende, nos territórios ficcionais de Mário de Carvalho, a recorrente e acutilante descrição de certos espaços e de comportamentos de heróis sem qualidades.

A título de eloquente exemplo, atente-se naquele "herói sem nenhuma conquista", tal como é apresentado Joel Strosse, por ex., em Era bom que trocássemos umas ideias sobre o assunto, homem de 50 anos, testemunha da Revolução de 1974, mas preso à rotina burocrática do trabalho numa Fundação. Ou recordem-se ainda os ociosos coronéis de Fantasia para dois coronéis e uma piscina, sem consciência da sua ridícula inutilidade.

Em todo o caso, como sugerido, esta conceçáo renovada de romance, ou de cronovelema, como forma de narrativa ancorada na contemporaneidade, não enjeita a longa herança do género romanesco; antes pretende adequar-se mais fielmente à filosofia ou mundividência destes tempos pós-modernos, aos seus novos valores, outros ritmos de vida e renovados códigos estéticos.

Finalmente, e como corolário do exposto, presenciamos a configuração gradativa e metaficcional de um novo género ou conceçáo libertária e atualizada de narrativa, na reflexiva pena de Mário de Carvalho. Por um lado, a escrita do autor recupera e celebra uma certa tradição ficcional (de Cervantes aos clássicos anglo-americanos como Lawrence Sterne ou Charles Dickens), apostada ela própria em reinventar, metanarrativamente, a arte da ficção, através de um novo realismo e até do grotesco quotidiano, mas também através de uma cultura do humor e da paródia, concebidos na sua funçấo eminentemente crítica. Desde pelo menos a teoria literária dos formalistas russos que, como referido, à paródia é reconhecido um papel decisivo no processo de evoluçáo literária, como processo privilegiado de desautomização de convençôes literárias. 
Por vezes, e isso é visível no emprego de um vasto leque de recursos formais do humor e da paródia, a escrita ficcional de Mário de Carvalho tem ainda um alvo privilegiado - a denúncia de certa tópica ficcional e retórica vazia -, aproximando-se assim do humor de um Flaubert, em Dictionaire des Idees Reçues, mas operando uma ampla caricatura que se estende da matéria literária aos clichés sentimentais. Ou seja, distinguindo-se como escrita de consciência paródica, opera uma espécie de purgação ou denegação do estereótipo e do epigonal; numa palavra, tem horror ao já gasto e ao já dito.

Por outro lado, a escrita metaficcional de Mário de Carvalho insiste na ideia de que esta conceção híbrida e libertária de poética ficcional é a mais adequada aos novos tempos em que vivemos, onde a tessitura narrativa congrega a criação efabuladora com a dimensão reflexiva de um narrador-cronista, obcecado em traçar uma anatomia provocatória e impiedosa do mundo de hoje, num impulso hilariantemente corrosivo: narrativa ágil com o ritmo da novela (picaresca ou de aventuras) ou mesmo do cinema; sobreposta ou enriquecida pela dinâmica estilística e reflexiva da crónica. Os gérmenes deste género híbrido já constavam da rica história do romance; mas Mário de Carvalho teve a lucidez de os acentuar.

Como analisado por Jean Bessière (2010: 31 e ss.), tendo-se tornado no género hegemónico no sistema literário moderno e contemporâneo, universalmente cultivado e reconhecido, não surpreende que o romance também se tenha transformado em espaço privilegiado de modalidades reflexivas plurais, superadoras de velhos paradigmas do género, bem como de limites e convençôes da própria escrita literária. No caso português, como se procurou demonstrar, a obra ficcional de Mário de Carvalho mostra-se um caso raro como ato de pensar, metaficcional e ironicamente, a escrita narrativa e romanesca - desconstruindo velhas ontologias e problematizando categorias tradicionais, para assim ousar propor novos rumos à narrativa contemporânea. 
(Página deixada propositadamente em branco) 


\title{
Sátira e o cepticismo: configuraçáo de personagens em Mário de Carvalho
}

\author{
Maria Joáo Simóes \\ Centro de Literatura Portuguesa / FLUC
}


(Página deixada propositadamente em branco) 
Le personnage décolle le Moi, le laisse flotter dans un espace symbolique plutôt qu'expréssif-indiciel, il apporte la coupure sémiotique et "l'autre scène".

Daniel Bougnoux

Há tanta personagem de romance que conheço melhor por dentro de que esse eu-mesmo que há vinte anos passava por aqui! "Realidade"- Álvaro de Campos

\section{Sentir e apreciar personagens}

A imagem do autor criando as suas personagens como o artesão molda as suas figuras a partir da greda informe surge intermitentemente na nossa memória, embora saibamos que se trata de uma imagem simplificadora. Parece que em algumas personagens a "massa aderente" persiste apanhando o incauto leitor - e às vezes até o próprio autor - que não se consegue libertar senão a custo do visco que elas vão fiando nas suas teias. Com efeito, numa espécie de revisitação do mito do golem, certas personagens, cujo desenho ganha consistência ao longo da leitura, conquistam um espaço na nossa memória, e teimosamente, persistem nela mesmo depois de abandonada a leitura e quando já se esfumam os contornos mais pormenorizados das intrigas.

Levantam-se entâo duas questôes: como e porque é que isto acontece? Mas já estas duas questôes desencadeiam uma outra: o desmontar e o explicar deste processo, de certa forma encantatório, não destruirá o encanto que as personagens nos proporcionam?

Coloca-se muitas vezes esta falsa clivagem entre o sentir estético e o olhar informado do conhecedor de uma determinada poética e dos seus procedimentos. Na verdade, um maior conhecimento do artístico nâo impede o sentir. Kendall Walton, por exemplo, na obra Mimesis as Make-Believe, ao expor a sua teoria da representação artística, reconhece a perspectiva dual do apreciador, o qual é capaz de participar no jogo ficcional e, ao mesmo tempo, observar o modo como está montado e como é composto esse jogo:

The appreciator's perspective is a dual one. He observes fictional worlds as well as living in them; he discovers what is fictional as well as fictionally learning about and responding to characters and their situations. (1990: 273) 
Intrinsecamente ligados, jogo ficcional e observação dependem um do outro; só analiticamente o primeiro visa a experência estética, e a segunda o saber sobre a poïesis ou o fazer específico de cada arte. Não existem separadamente - condicionam-se.

Indispensável à especificidade estético-literária surge, entâo, a destrinça entre apreciação estética e apreciação artística apresentada por Gérard Genette no segundo volume de L'Euvre de l'Art, no seguimento daquela outra distinção que o autor estabelece entre a mera atenção estética e a ponderada apreciação estética ${ }^{1}$.

Alguns aspectos destas diferenças são também levantados por Martin Seel, o qual, ao considerar a ideia de obra de arte como uma "configuração articulada", analisa vários modos de articulação da obra de arte com o mundo e estabelece três tipos de percepçáo estética: contemplativa, corresponsiva e imaginativa. Mas é preciso reter a ideia de que estas diferenças não são entendidas pelo autor como excludentes, sendo necessário, pelo contrário, entendê-las como um continuum transitável. Se às obras de arte, entendidas como "construçóes imaginativas" (1992: 131), se pode aceder por percepção imaginativa, isso não exclui a manifestação dos outros tipos de percepção. Aí reside, de certa forma, a complexidade das obras de arte:

En vertu de son unité esthétique, l'œuvre d'art donne l'occasion à l'homme de se rencontrer soi-même selon ses possibiliés fondamentales: la distance contemplative à l'égard du monde vécu, la participation corresponsive à ce monde, la perspective imaginative ouverte sur lui. Les œuvres d'art sont des objets esthétiques, dans lesquelles ces possibilités s'imbriquent de multiples façons. (Seel, 1992: 136)

Se o facto de se desvendar o modo como a personagem nos impressiona pode trazer uma compreensão diferente dela e até mesmo uma apreciação mais gostosa, será importante estar consciente dos vários níveis e das diferentes dimensões relativamente aos quais as podemos analisar.

1 Segundo Jean-Marie Schaeffer, a teoria especulativa da arte elidiu a distinção entre a esfera da estética e a esfera artística (1992: 344). Este autor reconhece a grande importância da destrinça genettiana entre intencional e atencional, que permite estabelecer diferentes tipos de julgamento estético: por um lado, aqueles que são feitos sobre objectos intencionalmente estéticos ou, então, sobre objectos não intencionalmente estéticos, ainda que utilitária e intencionalmente feitos, mas vistos agora numa perspectiva estética; e, por outro lado, aqueles que são realizados sobre o que não é intencionalmente feito, apenas existe (Schaeffer, 1996: 371). 
Ora, são múltiplos os modelos teórico-conceptuais sobre a personagem e são também diferentes os esquemas e as formas de os agrupar. É certo que a variedade de personagens, originada pela liberdade criativa dos artistas, constantemente póe em causa modelos rígidos de análise; porém, também é certo que esses modelos são heuristicamente produtivos não só no seu tempo como em momentos posteriores. À laia de lampejo prévio, e apenas para um esclarecimento inicial, poder-se-á reter as distrinças feitas por John Frow e por Gerald Mead. O primeiro aponta a dicotomia entre a concepção teórica humanista e a estruturalista relativamente à personagem e também as concepçóes estético-historicistas. Como alternativa fala ainda das teorias psicoanalíticas de abordagem da personagem. Já Gerald Mead (1990: 440) distingue entre a perspectiva referencial (onde inclui a biográfica, a psicológica e a sociológica) e a perspectiva textual (com várias vertentes: estrutural, funcional, imanente e actancial).

Curiosamente, alguns teóricos acabam de certa forma por reconhecer alguma vantagem na consideração conjunta das várias teorias, insistindo na sua complementaridade. Gerald Mead, por exemplo, afirma que "although there may be important theoretical differences between [the] two approaches, in practice they are not incompatible". Por seu turno, também Uri Margolin (2005: 57) póe em dúvida o facto de as diferentes teorias sobre personagens se excluírem, e, apoiando-se em James Phelan, defende uma perspectiva integrativa.

Partindo desta possibilidade integrativa, abordar-se-âo neste trabalho algumas personagens de Mário de Carvalho e, para esta abordagem, convocar-se-ão eclecticamente as diferentes teorias sobre as personagens sempre que tal se entender útil para um melhor discernimento delas. Preside a este eclectismo a convicção de que são as próprias personagens que suscitam diferentes abordagens, ora se salientando por uma determinada função estruturante dentro de um universo ficcional, ora apelando para um mais intenso desejo de identificação por parte do leitor, catapultando a abordagem e a análise para o lado da recepção.

\section{Personagem e identificação categorial}

Observar-se-á, primeiramente, a obra Casos do Beco das Sardinheiras, título sob o qual Mário de Carvalho recolhe um conjunto de pequenas narrativas de estranhos acontecimentos. A narraçáo abre sempre com o sintagma nominal "Uma ocasião" utilizado pelo narrador como bordão para contar 
cada um dos insólitos casos ocorridos no Beco: um homem que engoliu a lua, um gato que é uma pantera, uma corda que sobe para o céu, uma misteriosa pedra negra, etc. Sempre disposto a resolver as "escanifobéticas" complicações que surgem na atribulada vida do Beco, surge o Zeca da Carris que é talvez a personagem com mais destaque nesta obra, logo secundada pelo Zé Metade. Mas dizer que é mais importante não quer dizer que esta seja uma personagem grandiosa: em termos miméticos ele representa um simples morador de bairro pobre, representante da "arraia-miúda", como diz o autor no "Epílogo". Como as outras personagens, ele representa o meio ambiente popular de Alfama ou da Mouraria, onde as vidas dos moradores e vizinhos se entrelaçam num espírito marcado por um misto de interajuda e de pequena inveja, de colaboração, mas também de mesquinhez e grosseria.

Como é que esta personagem atrai o leitor? E porquê?

Ela suscita uma reacção mesclada, quase contraditória: por um lado, o leitor identifca-se com a lei de sobrevivência à qual a personagem obedece, uma vez que o Zeca da Carris está sempre apto a resolver os problemas que surgem no Beco; mas, por outro lado, ele sente uma certa distância, julga-se superior às soluçóes fáceis e simplistas adoptadas por Zeca que, por vezes, não resultam - como acontece relativamente ao caso do acidente do Quim Ambrósio que, por ter apanhado com uma telha em cima do lado esquerdo da cabeça, ficou falando uma "algaravia" que ninguém entendia e que Zeca tenta resolver com uma pancada idêntica no outro lado da cabeça.

Já o porquê da sua atracção nos remete para outro nível da projecção mimética da personagem, a saber, aquilo que ela representa em termos epistemológicos e filosóficos. Ora, neste sentido, aquilo que o Zeca da Carris representa é o que nos prende ao quotidiano. Isto, em si, parece pouco, mas no caso desta obra não o é, porque o quotidiano aqui representado está eivado de irrealismo: muito do que acontece no Beco é inexplicável segundo as leis racionais, sendo o suposto real constantemente atravessado pelo fantástico, o qual, em vez de ser considerado num plano de conhecimento diferente, é incorporado e absorvido pelo plano da realidade. (É o que acontece, por exemplo, quando a máquina de costura comprada pela mulher de Zeca revela ter a capacidade de gelar tudo numa área à sua volta em forma de paralelepípedo e, perante este insólito facto, o casal decide aproveitar este fenómeno utilizando a máquina de costura como congelador.) Assim, o sentido desse quotidiano representado transmuta-se através do fantástico, reduzindo ao absurdo a trivialidade do viver quotidiano. Com este jogo atinge-se, entáo, uma questionaçáo do absurdo da vida, uma questionação distanciada pelo cómico e pelo poder subversivo do fantástico. 
Ao nível discursivo, este questionar da existência encontra eco na expressão "não devemos confundir o género humano com o Manuel Germano" que, segundo Pedro Mexia, é "um aviso contra universalismos e moralismos", mas que, para além de indicar a não dissolução do "eu individual" no "eu social", aponta também a relação difícil entre ambos. Assim se compreende a razão pela qual, textualmente, a personagem é conhecida de modo familiar pelo diminutivo Zeca e pelo complemento determinativo "da Carris": por um lado, o indivíduo na sua singularidade, por outro lado, aquilo que lhe empresta essa ancoragem no social. Por sua vez, a linguagem identifica-o como pessoa simples e de trabalho, que tem necessidade de integrar rapidamente o inusitado no quotidiano, como acontece no caso da máquina de costura geladeira ao incorporar o inexplicável no real para que tudo regresse à normalidade. De facto, no início do texto, a personagem primeiro delimita o problema:

- O que me rala - comentou o Zeca - é não saber se isto é da máquina ou se é do sítio. Ora arredem-se pra lá! (49) (...)

e, depois, incorpora-o na normalidade:

- Bom o espectáculo que havia a ver já está visto. Agora agradecia que me desamparassem a loja que amanhã é dia de trabalho. (50).

A personagem ganha complexidade porque nela coalescem realismo e fantástico. Com efeito, para além da sua ancoragem no real, o seu desenho está embutido na categoria do fantástico, desencadeando assim uma apreciação estética que está em consonância com a apreciação categorial $^{2}$ requerida pela obra. Tal funcionalidade póe em evidência como a apreciação artística opera activando preenchimentos categoriais e genológicos.

Embora esta obra apresente alguns laivos satíricos, o predicado estético predominante é o fantástico e não o satírico.

2 Gérard Genette (1997: 190) aponta como distintivo da candidatura específica das obras de arte a "pregnância dos dados técnicos", sendo "a função artística o lugar por excelência de interacção entre o estético e o técnico". Assim, um dos sintomas passíveis de estimular a atenção estética será aquilo que designa por "saturação semântica" (idem, 69). Mas, de acordo com o teórico francês, para além da atenção, é imprescindível à relação estética essa outra dimensão que é a apreciação, que ganha contornos específicos na relaçáo artística, por causa dessa pregnância técnica. 


\section{Individuação e marcas distintivas das personagens}

Já em duas outras obras de Mário de Carvalho - Era Bom Que Trocássemos Umas Ideias Sobre o Assunto, de 1995, e Fantasia para Dois Coronéis e Uma Piscina, de 2003 - a categoria estética prevalecente é o satírico. Traçada como uma profunda sátira ao Portugal contemporâneo, Fantasia ... é uma obra que apresenta sobretudo personagens planas, a começar pelos dois coronéis já reformados e respectivas esposas que se reencontram no Alentejo. O Coronel Maciel Bernardes é, apesar disso, uma personagem um pouco mais importante, o que é atestado por dois aspectos: primeiro, pelo facto de o narrador o colocar logo em cena no contexto cronotópico da acçáo principal e de o dar a conhecer ao leitor "de chofre" - tomando conta da sua piscina, lendo o jornal e beberricando o seu uísque; segundo, porque o autor, logo a seguir, lhe concede várias páginas de caracterização directa, numa analepse narrativa que fornece ao leitor a explicação do seu posto e o modo como chegou ao casamento, etc.. Através desta analepse ficamos logo a saber que o Coronel é muito dado à "tagarelice" - um mal de que sofre todo o Portugal, como o autor afirma a abrir o romance:

Assola o país uma pulsão coloquial que põe toda a gente em estado frenético de tagarelice, numa multiplicação ansiosa de duos, trios, ensembles, coros. (...) O país fala, fala, desunha-se a falar, e pouco do que diz tem o menor interesse. O país não tem nada a dizer, a ensinar, a comunicar. O país quer é aturdir-se. E a tagarelice é o meio de aturdimento mais à mão. (2003: 11).

Ora o Coronel Bernardes, apesar de brandir contra este costume, "revela-se, ele mesmo, um conversador compulsivo" (2003: 25). Fora, precisamente, esse gosto pela conversação que o levara a anotar "episódios" num caderninho quando cumpria serviço como capitáo no ultramar, para poder contar mais tarde todas as histórias ${ }^{3}$. Caindo, depois, no meio da revolução adopta rapidamente a sua retórica de alarido, "alegre e algo confusa":

3 Este caderninho foi o que lhe salvou a vida, pois quando foi atingido por um estilhaço de granada o caderninho ficou estralhaçado, mas ele não. Esta perda, porém, ganha aqui um significado simbólico, uma vez que, a partir desse momento, ele nunca mais irá poder contar "histórias" de uma forma documentada e mais séria. 
E em tanto comício, tanta assembleia, tanta sessão de esclarecimento, o coronel, que o não era ainda, confirmou o seu gosto pela argumentação, pela dissertação, pela dialéctica. (2003: 27)

Já na reforma, afina o seu poder de argumentação ficando a administrar o condomínio do prédio onde vivia e onde massacra os condóminos com o exercício da sua habilidade retórica e persuasiva. Para além desta analepse inicial, o leitor terá ocasiáo de ir observando, ao longo da acção do romance, este gosto pela tagarelice nas longas e remansadas conversas que tem sobretudo com o seu colega Coronel Lencastre. Tratando-se de uma caracterizaçấo indirecta, caberá aos leitores inferir o seu perfil caracteriológico: o seu machismo mitigado (por algumas concessōes a bem da sua própria comodidade), o seu conservadorismo ideológico, mas sobretudo a superficialidade da sua cultura, a vacuidade da sua forma de pensar e a loquacidade prazenteira característica de um autocomprazimento que roça a infantilidade (a arma colocada por baixo da travesseira substitui - como esclarece o narrador - o ursinho de peluche). Não espanta portanto a sua reacção emotiva à traição da mulher, mesmo ali ao pé do seu nariz, com o jovem vedor que ele próprio chamara para encontrar água no monte, a fim de fazer uma piscina.

Uma síntese caracteriológica desta personagem teria pois de dar conta não só dos elementos que concorrem para a sua caracterizaçáo (física e psicológica), mas também teria de referir o seu papel e a sua funcionalidade na economia da obra e teria ainda de considerar a forma como o autor conduz a sua recepção pelo leitor.

Cumprindo este desidério, podemos dizer que o Coronel Maciel Bernardes é uma personagem da obra Fantasia para Dois Coronéis e Uma Piscina e que, num país de faladores como o que satiriza esta obra, o Coronel Maciel Bernardes é mais um "conversador compulsivo", com o treino que lhe dão as histórias do serviço militar, a experiência das andanças pela retórica apaixonada do tempo da revolução, pelo refinar da prática argumentativa na direcção de um condomínio e depois a retórica como pachorrento e aprazível entretenimento de militar reformado. Faz o papel de marido conservador, por vezes comodistamente permissivo, e ainda de marido traído furioso; representa a vacuidade de uma classe média, oriunda de diversas profissóes, que se reforma bastante cedo e que fica quase vegetando, sem ter grande coisa para fazer para além da maledicência. A sua funcionalidade na obra relativamente à dominante veia satírica torna-se evidente, sendo o leitor conduzido a tecer sobre ele uma opinião crítica e distanciada. 
Diferente já, é o caso de sua mulher a personagem Maria das Dores. Esta ousada figura feminina tem direito a caracterização física pormenorizada: enquanto jovem, ela surpreendia pelos seus gestos bruscos", era "morena, seca, alta, usava lentes de uma espessura que pareciam iô-iôs", mas tinha um trejeito de boca engraçado" e "uma maneira de inclinar levemente a cabeça, à pardalito" que agradaram ao então Major. Desde que se conheceram no baile de debutantes no Estoril, o que mais os aproximou foi o "desembaraço de linguagem" de Maria das Dores: uma linguagem desbragada, sem pruridos, eivada de regionalismos, de caláo e de asneiras - apesar de ser filha de "um terratenente" alentejano "com dois "de" e um "e" no apelido" (2003: 30).

Paradoxalmente, quanto ao primeiro aspecto - o ponto de vista físico - a personagem torna-se mais interessante para o leitor precisamente por causa da irregularidade da sua aparência - e não apesar dela. Como relembram Johan F. Hoorn e Elly A. Konijn (2003: 253), a tendência comum é considerar fisicamente mais belo o mais regular e simétrico em relação à média; mas, como já Gombrich e Leyton (entre outros) assinalaram, "em arte e na ficção, maiores ou mais brandos desvios da simetria, da regularidade e da harmonia são por vezes mais apreciadas que a simetria perfeita".

Se algumas características físicas são importantes na configuração desta personagem, o que sobressai, no seu caso, é o segundo aspecto, ou seja, é claramente a marca discursiva, demonstrando assim aquilo para que John Frow (1986: 245) chama a atenção: "characteres (...) tend to be also the subjects of discourse in their own right". Trata-se de um processo de individuação, se tivermos em conta a opiniáo de Amie Thomasson (2003; 146) quando distingue três diferentes aspectos do estatuto ontolológico das personagens, a saber, "their existence and survival conditions, identity and individuation". De facto, o que singulariza esta personagem no romance é a sua língua viperina e desbragada, invulgar numa mulher. Se se adoptar uma perspectiva de abordagem mais funcionalista e mais estruturalista, este aspecto tem como objectivo criar um factor de diversão, mas também serve a intenção subversiva da sátira. Aliás, a personagem manifesta uma tal propensão disruptiva que chega a interpelar o autor e a perguntar-lhe se tem medo de escrever sobre ela, desenhando assim uma metalepse narrativa, uma vez que se derrogam os limites ficcionais, como já se analisou anteriormente $e^{4}$.

4 Uma abordagem de como Maria das Dores acciona este jogo ficcional da metalepse foi realizada em artigo anterior - cf. Simões, 2006: 84,85. Gérard Genette designa de "metalepse" esse baralhar das fronteiras que separam as instâncias narrativas de uma e de outra parte do dispositivo enunciativo -cf. Genette, 2004: 10. 
Este casal - cuja relação se pauta por um acordo tácito da concessão de algum espaço livre - aparece por assim dizer duplicado num outro casal: o do Coronel Lencastre e sua mulher. Porém, na economia da obra, este outro par proporciona um contraponto funcional em termos de conflito entre geraçóes, pois através dele autor consegue trazer para o romance a personagem mais caricatural da sua obra, moldada como uma espécie de pot-pourri de cómico, ridículo, burlesco e grotesco colocado ao serviço da sátira. Trata-se do filho do casal, Nelson, que, embora já com quarenta e dois anos, é amante dos tags com os quais pressupostamente fustiga o mundo burguês, pois, em seu entender, servem "pra desconstruir, para

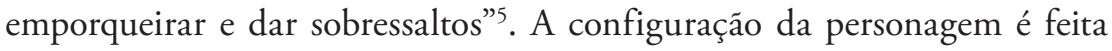
com base no seu discurso: a personagem ganha vida pelo discurso. Trata-se de um virulento pastiche, que, como se sabe, ao contrário da paródia visa a imitação - neste caso a imitação de um discurso pretensamente contestatário. A personagem representa o eterno adolecente auto-promovido a anarco-revolucionário - um pressuposto representante de uma "cultura de contestaçâo", como ele explica num "enternecedor" discurso:

vá lá pai, seja tolerante, que eu falo à moderna, linguagem viva, do povo mesmo, percebes? (...) É assim: eu é que não fossilizei no tempo, essa é que é essa, eu sou desenrascado, abertura prò mundo que está a mudar (...), meus, agora vocês, eu compreendo, já há a artrose, escoliose, ancilose, (...) é assim: não podem perceber, vão à janela e vejam-me esses muros, as portas dos prédios, os candieiros, o camandro, pá, lá está o meu, eu tou a deixar a minha marca nas paredes, e há uns gajos que sabem que sou eu, o Lencastre, o filho do coronel que riscou aquilo e que impediu a burguesia de ter ideias incolores contra os muros brancos, muro liso não tem expressão, os tags, atenção, atençấo, não os grafitti, são vida e libertação, o grafitte amocha, faz o jeito ao burguês, tem harmonia, cores, armado ao artístico, o tag não!, é pra desconstruir, para emporqueirar e dar sobressaltos. A volúpia do perigo, pá, nunca ouviu falar?, assim mesmo, pá, mas porque é que o pai há-de ter esse feitio?, (...) isto é vida, a nova cultura, hip-hop, man, que lá fora, como é que é?, os museus estão cheios de hip-hop, só cá é que é esta merda tradicionalista, pequeno-burguesa, tudo certinho, tudo direitinho e o caraças (...) (Carvalho, 2003:73-74)

5 Idem, 74. 


\section{4. "Identificação irónica" com a personagem: um paradoxo?}

Nesta obra, a maior parte das personagens não suscita senão uma apreciação distanciada por parte dos leitores; algumas há, porém, que conseguem suscitar uma certa dose de identificação que, no entanto, é sistematicamente posta em causa, numa espécie de volteio enredado, e quase parodoxalmente - elas suscitam aquilo que Robert Jauss chama, de forma algo contraditória ${ }^{6}$, "identificação" irónica:

Por identificación irónica entendemos un nivel de recepción estética, en el que al espectador o al lector se le traza sólo una identificación esperable que, luego, es ironizada o rechazada del todo. Estos dos tipos de experiencia (el de la identificación y el de la destrucción de la illusión), sirven para separar a los receptores de su espontánea tendencia hacia el objecto estético, provocando así su reflexión estética e moral. (1986: 283).

Este jogo distanciador é característico da escrita pós-modernista, e surge muitas vezes aliado à auto-reflexividade que os romances do pós-modernismo exploram de um modo intenso e reiterado ${ }^{7}$. Na obra Era Bom Que Trocássemos Umas Ideias Sobre o Assunto, o autor procede a vários jogos metaficcionais, os quais, como refere Ana Paula Arnaut (2002: 246), levam "o leitor a aceitar como verdadeira a representação do trabalho (des) construtivo que se vai expondo, mesmo que ele não passe de uma ilusão". $\mathrm{Na}$ verdade, neste romance, como também em Fantasia para Dois Coronéis e uma Piscina, o autor vai mostrando como se tecem os fios da intriga e como se desenham as personagens.

A este propósito, no romance Era Bom Que Trocássemos Umas Ideias Sobre o Assunto, é elucidativo o facto de o autor não atribuir logo um nome ao professor de Grego e de hesitar na escolha do nome, uma hesitação que se estende até ao momento em que o desenvolvimento da personagem torna esta situaçáo insustentável, chegando ao extremo

6 John Frow (1996: 233) chama a atenção para o carácter polémico desta expressão, sobretudo pelo facto de ela surgir subsumível ao conceito de "identificação" na categorização hierárquica realizada por R. Jauss.

7 Como esclarece Ana Paula Arnaut (2002: 233), esta utilização intrínseca e intensiva é diferente da auto-reflexividade accionada em romances anteriores apenas como "mero ornamento". 
de o autor reconhecer que personagem já ganhou direito a reivindicar uma presença mais sólida através da atribuição de um nome - elemento fundamental de individuação:

\begin{abstract}
Entấo aquele professor de Grego não tinha nome? Acho que já o vai merecendo, pelo seu esforçado protagonismo, a querer à força entrar nesta história. Como é que se há-de então chamar? Pensando bem fica-lhe a matar Vasco Reboredo, mas não há-de passar além de seis páginas, se tanto, embora exemplares. (1999: 159)
\end{abstract}

\title{
5. Personagens e o desnudar do fazer ficcional
}

O caso mais extremo do desnudar da construção narrativa surge pelo processo da metalepse - recurso utilizado quer no epílogo de Casos do Beco das Sardinheiras, quer no diálogo com a personagem Maria das Dores em Fantasia para dois Coronéis e Uma Piscina, como se viu em ocasião anterior ${ }^{8}$.

No caso deste último romance ainda encontramos outra forma bastante inovadora e bem mais subtil de mostrar o fazer da ficçáo: de facto, dentro do próprio romance há personagens que constroem ficçóes criando assim uma espécie de mise en abîme do ficcional. É o caso do homem do mel que, à laia de Mofina Mendes, vai imaginando uma série de sucessos que depressa cairão por terra.

Mas, para além de certas personagens figurantes, este processo ganha relevo na construção de uma personagem bem mais importante, muito especial, de seu nome Emanuel Elói, vedor e mestre de xadrez, que constantemente inventa e cria histórias: "Alto, desengonçado, com um cabelo espigado, às farripas e uma cara agaiatada, de traquinice benigna" (2003: 66) - tal era o jovem vedor e mestre de xadrez (ou "professor" de xadrez, como costumam chamar-lhe).

Como se esboça, entâo, o perfil desta complexa personagem? Como se enquadra no jogo ficcional inventado pelo autor?

No mosaico ficcional das personagens, trata-se de um jovem que se situa nos antípodas daquele (pseudo) jovem Nelson (cujo discurso se vislumbrou); ou seja, Emanuel Elói arranjou um modo de subsistência - é vedor -, sustenta-se a si mesmo e ao seu velho Renault Quatro e criou o seu espaço na sociedade. Não se pauta pelos valores das geraçóes anteriores, não acredita

\footnotetext{
8 Cf. a anterior nota 4 .
} 
neles, formou os seus próprios valores e arranjou um modus vivendi de forma a não sofrer demasiado com a sociedade que o rodeia. Há algo de epicurista na sua forma de encarar a vida, de aproveitar o que lhe vem bater à porta a começar pelas mulheres que, gostando dele, livremente se lhe oferecem... Rejeita o prazer pelo prazer e náo adere ao donjuanismo patético que lhe aconselha e pratica o seu tio. Compensa uma vida algo vulgar com toda uma força imaginativa e evasiva: inventa histórias fantasiosas que julga poderem encantar quem as escuta; porém, não é propriamente um alienado, fechado ao exterior, como nos revela o narrador: "Emanuel, apesar da juventude, como já se deixou perceber, era atento e prevenido." (68)

Todavia está longe do espírito empenhado de outros tempos: Emanuel representa uma nova geração que não se interroga muito sobre os porquês, a qual, relativamente a certos aspectos, é ingenuamente crédula e em relação a outros distanciada e crítica - o que surge simbolicamente representado nesta estranha conjunçáo profissional de vedor e mestre de xadrez: o irracional e o racional. Como a psicologia explica, o verdadeiro vedor acredita no que faz; pelo que se coloca a hipótese de as manifestaçóes ocorridas - a famosa vibração das varinhas de freixo ou das varas de metal para encontrar água - poderem ser explicadas por algum intuicionismo que se manifesta psicossomaticamente ${ }^{9}$ no tremer do sujeito que, por sua vez, se comunica ao objecto. O ser 'vedor' representa o lado crente da personagem, mas também o "desenrascar-se" em termos de ganha-pão. O xadrez representa um potencial de inteligência negligenciado e subaproveitado, num país que não prima pela sabedoria.

Ele é o representante de um tipo de geração jovem, uma geração que não acredita nos caminhos que entusiamaram os jovens de 68, uma geração que não sabe completamente o que quer, que anda à procura - anda à procura da água, o que metonimicamente talvez signifique o que pode salvar a terra -, mas, por outro lado, uma geração que sabe bem o que não quer. Comicamente isto reflecte-se na escolha do seu nome benigno e abençoado,

9 James Randi explica a movimentação das varas dos vedores ou a rotação dos pêndulos dos radiestesistas como decorrente de um fenómeno psicológico conhecido como «ideomotor effect» ou (à falta de melhor tradução) «efeito ideomotor», que define como: «movimento corporal involuntário originado não por uma estimulação sensorial, mas antes por uma ideia ou por um processo mental». (...) No final a "descoberta» deve-se simplesmente à grande probabilidade que existe de se encontrar água quando se faz uma perfuração num sítio qualquer de um terreno onde já se prevê que ela existe, isto é, precisamente aquele onde o vedor é levado a «trabalhar». Cf. Rodrigues, 2005. 
e na resposta que dá a Maria das Dores quando ela insinuadamente lhe pergunta:

- E de que é que gostas mais?

- Gostar, gostar, não sei bem, mas não aprecio bife com natas nem bacalhau com natas. Aliás de uma forma geral, detesto natas. (67)

\section{A complexidade de um verdadeiro "céptico"}

Espreite-se agora a personagem mais densa da toda a obra de Mário de Carvalho: Lúcio Valério Quíncio, personagem que pertence ao romance histórico intitulado Um Deus Passeando pela Brisa da Tarde, onde desempenha o papel de protagonista. A sua importância define-se em grande parte pelas suas funçóes de magistrado - duúnviro - de Tarcisis, cidade da Lusitânia no tempo do império romano de Marco Aurélio Antonino (1994: 27), no séc. II; mas o seu relevo advém sobretudo dos seus comportamentos e do seu sentido de vida os quais são pautados pelos ideais de romanidade a que ele conscientemente alude: "Dignidade. Gravidade. Romanidade. Humanidade." (1994: 16). As suas características psicológicas são abertamente propaladas pelo decênviro Pôncio (Velutio Módio) em plena cúria que Lúcio convocara para se proceder à substituição do falecido duúnviro Trifeno. Demagogicamente Pôncio, sabedor de como dominar a assembleia, reconhece primeiramente que Lúcio é "um homem íntegro" e depois traça-lhe o elogio, mas com o fim de lhe arrojar sobre os ombros toda a responsabilidade da magistratura, impedindo a eleição, ou a cooptação de outro duúnviro:

- Proponho, cidadãos, que o duúnviro Lúcio Valério Quíncio, aqui presente, modelo de piedade, de moderaçáo e de sageza, assuma com aprovação da cúria o duplo mandato, substituindo nas suas funçôes o duúnviro Gaio Cecílio Trifeno, que já viveu! (1994: 41).

Estas características funcionam em contraste relativamente aos defeitos que, por sua vez, Lúcio identifica na atitude dos decênviros: o egoísmo, a ociosidade e a pusilanimidade. Há a acresentar ainda a hipocrisia - um tema a inferir pelo leitor sobretudo a partir do episódio do pretório quando Lúcio comunica a Pôncio que, para refazer a muralha, terá de abater uma das suas casas. Louco de fúria, Pôncio atribui isso à inveja, à prepotência, 
à ganância e ao abuso de poder, deixando Lúcio estupecfacto e perplexo, pensando (e o leitor juntamente com ele) que os seus concidadáos "projectavam [nele] os traços do seu carácter, como se [fossem] afinal do mesmo barro" (1994: 78). Fica assim estabelecida esta polaridade elementar do romance que permite distribuir e relacionar as personagens dentro dos valores do universo ficcional romanesco, tanto mais que elas vão ser postas à prova nos terríveis acontecimentos que constituem o núcleo da intriga do romance: o ataque e o cerco dos "mouros" e a resistência dos habitantes de Tarcisis.

Todas estas qualidades do protagonista o leitor irá comprovando ao longo do romance, cumprindo-se assim a ideia, recuperada por Helena Buescu ${ }^{10}$, de encarar a personagem como uma proposta de sentido consistente:

... é provável que a personagem literária realize uma acção crucial na criaçáo da "constância de sentido" no interior do texto, ao lado de outros procedimentos textuais (...) trabalhando na mesma direcção. Esta "constância de sentido" não pode, no entanto, ser entendida como determinaçáo apriorística e definitiva da composição da personagem, pela simples razão de que (...) a noção de progressão narrativa (Phelan, 1989) e a composiçáo relacional de toda e qualquer personagem impedem essa fixidez enquanto princípio. (1995: 84).

Apenas o decurso do romance permitirá, de facto, corroborar as qualidades do protagonista. Caberá ao leitor ir inferindo, a partir das atitudes e decisóes de Lúcio, se ele corresponde às características que lhe são atribuídas. O leitor deduzirá, então, a sua sageza não só sopesando a validade e as consequências das suas decisões, mas também a partir das ponderaçóes e dos raciocínios que precedem ou seguem as suas acçôes. $\mathrm{Na}$ verdade, o leitor acompanha os desafios enfrentados por Lúcio guiado pela sua mão, isto é, pela sua perspectiva e pelo seu verbo, pois a narrativa se faz em primeira pessoa, sendo frequentes frases do tipo "Tenho toda a consciência de que todo este discurso foi um tanto injusto" (156). Por este processo o leitor tem acesso aos pensamentos e sofrimentos do protagonista, nos diferentes episódios: a reunião na cúria, o discurso de Rufo na Taberna, a morte de Clélia, etc.. É através da sua perspectiva que conhecemos as outras personagens do romance e toda a teia de

10 Como esclarece Helena Buescu (1995: 105), “este conceito é proposto por Hans Hörmann (1976) e sublinhado, entre outros, por Siegfried Schmidt (1982). 
relações que entre si estabelecem. É, sobretudo, através da sua visão que lemos, não só os seus pares, como as outras personagens: Aulo, centurião ao serviço da cidade, que é a sua mão direita, Mara, sua subtil mulher, Airhan, o espião, Rufo, o padeiro, filho de liberto, ambicioso pretendente a edil, que se aproveita da situação de crise para se evidenciar e alcançar os seus desígnios, Mílquion, o chefe do grupo dos convertidos cristãos, que arrasta os seus prosélitos e também converte Iunia, a filha de Máximo Cantaber.

O lúcido e comedido Lúcio fica perplexo apenas diante desta última figura: Iunia. Ela tolhe os seus movimentos e confunde os seus pensamentos, incomoda-o ao mesmo tempo que o atrai. Reiteradamente o próprio Lúcio se interroga: ter-se-á deixado "enfeitiçar" pela voluntariosa Iunia?. Aquilo que talvez possa definir melhor o desenho da personagem Iunia é aquele tal "não sei quê" - essa espécie de mais-valia estética de que nos fala Benito Feijóo (1998: 10), uma "graça oculta" -, que encanta Lúcio sem ele saber porquê. Esta personagem faz jus à ideia da beleza como o que chama a atençáo, como o que apela provocando ${ }^{11}$. Para além do seu porte e dos seus olhos verdes é-nos dito que é muito linda, mas o que mais se salienta nela é uma vontade de afirmação que Lúcio lê como "obstinação" e "teimosia" (1998: 148). Um tentame de explicação mais determinista da personagem é ensaiado pelo seu velho pai Máximo Cantaber que explica a Lúcio como a morte da máe e depois do marido a teria perturbado ao ponto de a tornar vulnerável a estranhas influências, como o cristianismo. Por outro lado, o próprio Lúcio pode testemunhar a permissividade e complacência da educação de Máximo pelas atitudes de Clélia, irmã de Iunia - uma situação que irá ter consequências graves, de certa forma originando a sua terrível morte às mãos dos mouros. Mas estas explicaçôes vão-se tornando claramente insuficientes para cingir e discernir a personagem e o modo como ela se impóe a Lúcio, tal como ele lucidamente compreende a meio da intriga:

Iunia começara por ser apenas a filha desviada do meu amigo. Um nome, uma vaga reminiscência. Um problema dele. Era agora uma companhia que eu cegamente prezava, sem saber bem porquê. Um problema meu. Impunha-se-me como que um obsidiante desafio de conseguir chegar a Iunia, à verdadeira Iunia, à humanidade de Iunia, por detrás daquele enleio espesso de frases e atitudes. (166)

11 Como esclarece José Augusto Mourão, M. Ficino ligará a "beleza”, kallos, ao verbo kaléo, "chamar" e di-la-á provocatio. Quer dizer que toda a beleza é provocante (1998: 54). 
Toda a actuação de Lúcio vai no sentido de chamar Iunia à razão, porém, ela representa a alteridade de uma outra razão. Ela funciona como um exemplo de entrega a uma causa, opondo-se constantemente a Lúcio. Revela, porém, constância, firmeza na sua luta por uma causa que julga superior, mesmo perante a ameça de morte. Assim sendo, o sentido desta personagem desborda para além da compreensão de Lúcio, deixando a pairar um lado residual cujo significado choca Lúcio, por se encontrar num extremo diametralmente oposto ao seu: ela figura a convicção e a crença, ele representa um modo de pensar prescrutador e, por isso, desiludido e céptico.

Para se inteligir a verdadeira profundidade deste cepticismo é necessário ver como ele decorre da avaliaçáo que Lúcio faz do xadrez das diferentes personagens que o rodeiam. Por exemplo, Airhan - um informador dos magistrados -, apresentado, ao fim e ao cabo, como espiáo, é caracterizado directamente pelo narrador Lúcio e é sob a sua perspectiva avaliativa que tal personagem nos é apresentada. Cheirava mal e apresentava-se com um "vestuário compósito, quase andrajoso, barba caótica, tronco espesso, braços curtos, [como] os trabalhadores de portos". Marca a sua presença pelo cheiro impestante e salienta-se pela sua cobiça, pela sua labilidade e habilidade em proveito próprio.

$\mathrm{Na}$ complexidade do romance, até a certa altura, uma outra personagem parece estabelecer o contraponto com esta: trata-se de Aulo Mâncio, o centuriáo ao serviço da cidade e prefeito às ordens do pretório (35), sempre tâo rígido na sua "soturnidade discreta", sempre de uma "fidelidade tão constante e humilde". Ora, no contexto de corrupção de um império romano dissoluto, a presença de alguém sempre táo respeitador das diferenças de estatuto faz com que Lúcio se interrogue sobre o seu "conformismo": "Quem era este Aulo, afinal?" (198). Esta interrogação mostra bem como as personagens se vão configurando ao longo da ficção e como a sua "individuação" (no sentido conceptual de configuraçâao das personagens acima referido $)^{12}$ depende do jogo relacional não só entre a intriga e as personagens como também entre as próprias personagens. A esta interrogação de Lúcio, levantada a meio da acção (no capítulo XII), sobrevirá a constatação, lá mais para o final do romance, das verdadeiras motivaçôes que determinam o seu comportamento ${ }^{13}$ que mais do que servidor se revela servilista e marca a personagem como "vira-casacas". Por seu turno, o ponto de vista

12 Cf. Uri Margolin, 2005: 55.

13 Insinua-se, por exemplo, aquilo que o leva a matar o esquálido poeta Lúculo Cornélio motivado por ciúmes relativamente Galla, sua mulher. 
funcionalista de análise das personagens pode ser aqui bem esclarecedor já que ele passa de adjuvante a oponente. É mais um conterrâneo que cede à corrupção e se deixa seduzir por galas e gloríolas: aliciado pelo senador Calpúrnio (que lhe promete o comando da $1^{\text {a }}$ coorte dos centurióes - o primipilato) trai a confiança de Lúcio e conluia-se com os decênviros. Funciona como mais uma acha no descrédito que Lúcio vai acumulando sobre os cidadãos romanos.

Será esta apenas uma entre as muitas traiçóes dos decênviros ${ }^{14}$ e dos senadores de Tarcisis, os quais, movidos pela corrupção, pela vontade de vingança e por uma mesquinha, reles e cruel concepção da romanidade e dos seus ritos, funcionam, durante toda a intriga, como oponentes do espírito de cidadania que determina acção política de Lúcio, pautada por um sentido de rectidão e de justiça. No final chegam mesmo a torpedear Lúcio encontrando-se, pela calada da noite, com Scauro, o comandante da VII Legiáo e ajudante do procurador imperial, para intrigar contra ele e denegrir a sua pronta, enérgica e corajosa acção que evitara a tomada de Tarcisis pelos "bárbaros".

Mílquion é, no romance, o bispo dos cristãos: anda difundindo a ideia do Deus salvador e tentando aumentar o número de prosélitos. É visto como um oportunista - até por Aulo que o avalia como "um caçador de oportunidades" (157) -, é um estrangeiro - sírio, embora segundo Lúcio mais parecesse "um macedónio, ou um lídio ${ }^{15}$, pois não tinha feiçóes asiáticas. É alto, de traços regulares e tem os olhos claros e cabelos crespos e cinzentos, "barba emaranhada, cinzenta e descuidada. A descrição física desta personagem é feita com algum pormenor, principalmente por dois motivos: primeiro, ao nível interno, essa descrição permite infundir no leitor, subrepticiamente, uma ideia da idade do próprio Lúcio, pois ele diz que o estrangeiro tem mais ou menos a idade dele, e como Mílquion tem os cabelos cinzentos o leitor depreende que Lúcio esteja na maturidade; em segundo lugar, esta descrição permite estabelecer a diferença do estrangeiro relativamente ao "padrão" da romanidade. Lúcio repara nas suas mãos "largas e nodosas" e a partir deste pormenor desduz que ele "já tinha vivido sete vidas (...) e nem todas bem vividas...”. Este pormenor liga a descrição física à psicológica e vai incutir no leitor alguma desconfiança relativamente à profundidade e seriedade das sua motivaçóes, já que Lúcio

14 Chamava-se Decênviro, em Roma, sob a República, a cada um dos dez membros de um tribunal permanente encarregado de julgar os processos relativos à liberdade.

15 Lídia, uma região da Anatólia, hoje Turquia. 
detecta nele uma "arrogância tranquila, impante de falsa ciência, dizedora de frases, pairando acima dos destinos do mundo" (156), e como tal, considera-o um "farronqueiro" (147). A pouca fiabilidade desta personagem advém, do facto de ir crescendo em proporção inversa à fiabilidade que o leitor deposita em Lúcio. Como Lúcio o vê com desconfiança, tal impede a identificação do leitor com esta personagem e, por extensão, com o que ela representa - o mundo do pensamento cristấo, um mundo ideológico e religioso diferente, cujos princípios não convencem Lúcio. $\mathrm{O}$ facto de ser diferente, de carrear uma lógica diferente, alerta Lúcio para a situação de não-diálogo, de choque cultural, deixando assim em aberto, no romance, a representaçáo de uma fractura, uma grande divisão nas formas de pensar. Cabe assim ao leitor um jogo abdutivo ${ }^{16}$, através do qual ele terá de inferir o carácter da personagem Mílquion, terá de avaliar a força persuasiva da crença cristã e deverá ajuizar o modo tenaz e os meios algo ínvios escolhidos para implantar crença (à semelhança do que acontecerá com qualquer outra crença).

Por tudo isto, Lúcio é uma personagem cuja complexidade se desenrola, se desdobra e se abre paulatinamente ao leitor. As suas qualidades de homem íntegro cativam desde o início o leitor que com ele rapidamente se identifica. (É curioso até pensar como mesmo as pessoas más facilmente se identificam com os "bons" da história...). No seu caso, esta identificação prossegue em crescendo até ao final do romance, concorrendo para tal o facto de ele próprio ser o narrador, como já se referiu, e de ser configurado pelo autor como um narrador fiável. Se este processo permite o acesso aos seus pensamentos, às suas próprias incertezas e autocríticas é porque, a montante, o autor escolheu construir mimeticamente a personagem representando um homem pensante; por seu turno, a jusante, o leitor faz a leitura mimética da personagem passando por diferentes graus da identificaçáo tal como foram identificados por Jauss: admirativa, simpatética e catártica. De facto, o poder raciocionante da personagem, assim todo desvelado perante todo o leitor, torna-a impressionante e causa admiração: os seus combates entre sentimento e razão, os seus constantes exercícios de autocontrolo originam um progressivo envolvimento do leitor com a personagem.

Amiúde, os exercícios racionalizantes do protogonista misturam-se com sentimentos e desejos que desenham a parte emotiva da personagem. Lúcio deseja ver Iunia, a sua presença causa-lhe prazer - embora algo amargo e estranhamente dorido. Lúcio só não é mais voyeurista porque o seu super-ego

16 Cf. Uri Margolin, 2005: 55. 
limita o recorte do seu prazer a uma mediania platónica e pelo facto de se aperceber da escopofilia de Iunia, ou seja, do seu desejo de se ver observada. Esta é uma forma de "identificação cinemática em relação ao prazer visual" ${ }^{17}$ (que a ficção cinematográfica tanto explora - basta pensar no célebre filme $A$ Janela Indiscreta de Alfred Hitchcock); por sua vez, o leitor identifica-se com esta vivência perturbada de Lúcio a qual lembra como "táo contrário a si mesmo é Amor", como ele provoca esse "contentamento descontente" - esse sentir contraditório que o leitor provavelmente já experienciou e que ficcionalmente revive.

Mas, em toda a identificação do leitor com esta personagem, há uma peculiaridade: é que, com o inteligente Lúcio, os leitores vão aprendendo a criar uma distância avaliativa relativamente às outras personagens, vão ganhando uma espécie de sabedoria - quais "sábios incautos" - treinados pela sua ironia coleante, a qual permeia a sua apreciação dos que lhe são próximos, das suas ínvias aspiraçóes e das suas mesquinhas existências. Exemplo desta ironia é a penúltima senha (bebida em Virgílio) que dá a Aulo depois da sua traição: "Tâo mudado do que era..." (295)

Lúcio, como personagem, atinge assim uma dimensão mais vasta exigindo um nível de leitura superior, não só porque representa uma "ideia" do mundo, claramente humanista e uma visão do seu tempo, marcada por um ideal de romanidade e cidadania, mas também porque a abstracção gerada a partir destas ideias the confere uma amplitude universalizante. Como se isto não bastasse, Lúcio representa ainda a questionação da crença, que se plasma através do seu desasjuste com a crença cristá e/ou pagá, redundando nesse seu cepticismo profundo - que faz dele um verdadeiro "céptico". Na verdade, ele não só não acredita nos deuses (sejam eles quais forem) como não acredita nos homens, por isso o seu confronto com Iunia é tấo doloroso e penoso: é o choque entre o descrente e o religioso, bem vívido ainda no nosso mundo actual.

Porventura é o facto de a este descrédito se somar a desilusão que lhe traz a ordem de dar prisão aos cristãos enunciada por Marco Aurélio Augusto - uma personalidade com a qual sentira afinidade pois nele pressentira uma idêntica descrença relativamente a esta questấo dos ritos e espectáculos populistas - que o leva, em determinado momento, a ser atraído pelo suicídio, fazendo balancear o cepticismo lúcido por que se rege. Mas, nesse momento, eis a pergunta que a si próprio dirige:

17 John Frow (1986: 239) fala destes tipos de identificação chamando a atenção para o contributo deste tipo de abordagem psicologizante. 
Iria eu atraiçoar derradeiramente o lema de Epicteto ${ }^{18}$ que sempre quisera - com tanto insucesso - adoptar como norma de vida "Temte! Aguenta!" (287).

Finalmente, em Lúcio, cujo nome, claramente simbólico, vem de luz ${ }^{19}$, vence o estoicismo.

Antes do julgamento dos cristãos, que será obrigado a conduzir, faz um sacrifício propiciatório, confessando que essa é a linguagem que tem para comunicar com a Providência. Dirige o ofertório à Justiça, mas evoca também o Deus cristáo de Iunia (296), aproximando-se da ideia de Cristo de Ricardo Reis - Cristo é apenas o deus triste que faltava.

Maquiavel ecoa também neste cepticismo, sobretudo no final, pois o não-reconhecimento por parte dos seus concidadãos das suas acçóes que salvaram a cidade (e o seu consequente exílio) advém do facto de ele náo ceder ao jogo de agradar às massas. $\mathrm{O}$ facto de ele não condescender com o populismo fácil e de rejeitar a aura enganadora de um ritualismo religioso supercifial ser-lhe-á fatal. De certa forma o narrador no final apercebe-se da sintomatologia que Fradique Mendes já diagnostica e para a qual alertara Guerra Junqueiro ${ }^{20}$ : o sentimento religioso não sobrevive sem ritos. Também no que diz respeito à política, só com uma muito desejada e esperada distribuição de louros e benesses, um político perdurará no poder. Por isso, a última senha que dá Aulo ${ }^{21}$ antes de partir para o exílio é também irónica: "aura popular..." (295).

Finalmente caberá a Lúcio, e aos leitores que com ele se identifica(ra)m, acatar a lição de uma máxima de Epicteto, que a personagem por certo intuiu:

Lembra-te que és actor numa peça, curta ou longa, onde o autor te quis fazer entrar. Se ele quer que desempenhes o papel de um mendigo, é necessário que o faças o melhor que te seja possível. (...) Porque é a ti que cabe desempenhar a personagem que te foi dada; mas é a um outro que cabe escolher-te a personagem.

18 No antepenúltimo capítulo (p. 279) há mais uma referência a Epicteto, corroborando assim de forma explícita a presença do seu ensinamento.

19 "Lúcio, do Latim lux (gen. lucis), significa "luz".

20 Também Jacinto, personagem queirosiana, juntamente com a Odisseia, mantém consigo o Manual de Epicteto.

21 Não será por acaso que o significado de Aulo, pelo latim Aulus, é “velho". 


\title{
Escrever tem arte e tem segredos... Era bom que trocássemos umas ideias sobre o assunto
}

\author{
Maria de Fátima Silva \\ Universidade de Coimbra
}


(Página deixada propositadamente em branco) 
A posição da literatura é muito ambígua. É ela a rainha da cultura, a grande dama, a grande experiência, revelação e tremor; mas com uma facilidade pasmosa cai destes cúmulos para se converter em passatempo, em hieróglifo, em exibição de destreza verbal.

Zagajewski, A., En la belleza ajena, trad. esp. de A. E. Diaz-Pintado Hilario, $97^{1}$.

Era bom se trocássemos umas ideias sobre o assunto é não apenas uma narrativa bem sucedida de quadros e personagens da realidade portuguesa contemporânea, como um 'manual' de arte de escrever. 'Manual' entenda-se, construído sobre um diálogo frequente entre o narrador e as suas personagens, de um lado, mas principalmente entre M. Carvalho e o seu leitor ${ }^{3}$. Em apontamentos breves, dispersos por momentos múltiplos, o autor medita e comunica preocupaçóes de concepçáo e estética, relacionadas com a estrutura da narrativa, o desenho das personagens e a eficácia da linguagem, a que ele mesmo deita mão no seu romance ${ }^{4}$. Atento às normas - algumas delas bebidas na tradição greco-latina, outras arquitectadas e estabelecidas ao longo de séculos de criação e de crítica literária - e à estética da transgressão que a partir delas se constrói, M. Carvalho é o prosador atento, profissional, além de um extraordinário criador em

1 2003, Valencia, Pre-Textos.

2 52003, Lisboa, Caminho.

3 M. Carvalho domina uma técnica eficaz do que Reis, C., Macário Lopes, A. C. (72007), Dicionário de narratologia. Coimbra, Almedina: 207-210 designam por "intrusão do narrador", com índole e motivação diversa, mas com o objectivo permanente de projectar no enunciado narrativo a subjectividade do narrador. O que, no aspecto que nos propomos abordar, diz respeito ao próprio processo narratológico.

4 Estamos perante o que Genette, G. (1972), Figures III. Paris, Le Seuil: 244 denomina como metalepse, como o processo de intervenção do narrador no curso do texto, com objectivos que são neste caso, antes de mais, lúdicos, mas que não deixam de ser também doutrinários. Na mesma linha, é ainda de recordar Malina D. (2002), Breaking the frame: metalepsis and the construction of the subject. Columbus, Ohio State UP: 9: "A metalepse pode não se ficar por um mero efeito retórico que nos afecte - que nos indique novas formas de ler e de pensar o nosso próprio mundo; pode ter também um efeito transformativo, permitindo-nos, pontualmente, experimentar novas formas de ser, na medida em que romances metalépticos constroem, de alguma forma, a nossa subjectividade”. Sobre metalepse, vide ainda Reis, Macário Lopes ${ }^{7} 2007$ : 232-233. 
língua portuguesa. Como bem afirma Marta T. Anacleto5, ainda que num contexto diferente, mas com igual propriedade para o caso que avaliamos: "Por não poder submeter-se a uma tipologia rigorosa do romance, refugia-se num modelo de escrita que remete, constantemente, através da paródia e da autocontemplação irónica, ao âmbito próprio de uma semântica da escrita". Assim se abre espaço a que o romance se interrogue sobre si mesmo.

Mas a par da própria escrita, o leitor atento há-de reparar como, neste romance, pela mão das personagens, outras escritas se esboçam, em tonalidades contrastantes. Há quem escreva e acumule peças de teatro, o Jorge Matos, o antigo professor de Francês, em fase de acumular ex-vivências: ex-vítima da PIDE, ex-marido de uma médica, ex-revolucionário, ex-jornalista, ex-professor (47), mas, em continuidade, autor de peças teatrais. Há a prosa jornalística que nos chega, nas suas diversas concepçóes e tonalidades, sobretudo por obra da Eduarda Galvão. E há, mais esparsos, laivos de outros discursos - académico, burocrático, publicitário -, no que é, no seu conjunto, um puzzle bem sucedido de cambiantes no uso da língua. É sobre esta polissemia do texto que nos propomos tecer algumas consideraçôes.

\section{Estratégias de construção da narrativa}

Manda a natureza das coisas que seja o prólogo, e o uso que permite, a primeira ferramenta a considerar na arquitectura de um romance, ou de outra qualquer narrativa. E é também já a partir deste momento inicial que Era bom se afirma crítico de si mesmo e capaz de rejeitar, conscientemente, convençóes instituídas para enveredar por uma opção divergente. Ordem e estilo denunciam, pela transgressão, todo o seu potencial.

Desde sempre que o prólogo, a palavra com que o grego designou a abertura de uma narrativa - ou sobretudo de uma peça teatral - (pró-logos, 'o que antecede a história ou narração'), teve, por função essencial, informar, antecipar ideias, motivos, linhas de acção, orientar o leitor ou espectador para uma expectativa. Ao propósito, juntou-se o sentido de eficácia, a dosagem do conteúdo, o ritmo das informaçóes, o impacto emotivo

5 1996, "(Sub)versions du "cliché" romanesque au XvirI siècle: le "roman bourgeois" de Furetière”, Confluências 14: 99. 
de que poderia ser capaz, para cumprir plenamente o seu papel $^{6}$. É desses pressupostos que M. Carvalho dá conta, à página 18:

E porque já vamos na página dezoito, em atraso sobre o momento em que os teóricos da escrita criativa obrigam ao início da acção, vejo-me obrigado a deixar para depois estas desinteressantes e algo eruditas consideraçóes sobre cores e arquitecturas, para passar de chofre ao movimento, ao enredo. Na página três já deveria haver alguém surpreendido, amado ou morto.

Uma abertura demasiado longa, expositiva, erudita, corre o risco de entediar o leitor - ou, sendo o caso, o espectador - e desmobilizar atençóes. E convive mal com a componente 'acção', perigosamente adiada. Mas há também o problema da informação, em contrapeso com a sedução que se espera de um texto de abertura. Será a informação o essencial deste exercício delicado que é dar início a uma narrativa? Não, é a preferência evidente do autor de Era bom, que continua:

E enquanto me apresso, vou protestando que houve um escritor que demorou trinta magníficas páginas a acordar de um sono e outro que gastou muitas mais a tentar demonstrar, fraudulenta mas genialmente, que a baleia é um peixe.

De resto, o factor 'surpresa' é imprescindível num relato atractivo e impóe, entre prólogo e intriga, um equilíbrio bem medido. Que algo sobre, de imprevisto, para além daquilo que um prólogo obriga a prever.

Uma quebra no romance, a separar uma primeira de uma segunda parte, reclama um novo prólogo e, mais uma vez, uma reconsideração de eficácia. Apesar de abertura, o prólogo sucede agora a uma quebra da acção, a um intervalo de tempo; e, por isso, se lhe exige atenção não só ao que se segue, mas àquilo que, nesse tempo, aconteceu. Um outro instrumento, o da sinopse, se mostra entáo necessário; em vez de um começo "logo de rijo, e em festa", a reverência à teoria exige a tal sinopse. Teatro e novela voltam a confluir na metodologia de conactar tempos e de assegurar a atenção do destinatário. Cumprida a regra, pode o narrador certificar-se com alívio: "Estamos situados?" (117-119).

6 Sobre a natureza do prólogo, designaçôes alternativas, dimensão e funçôes, vide Reis, Macário Lopes ${ }^{7}$ 2007: 343-344. 
Com o momento da abertura, que o romance Era bom situa in medias res, vem a necessidade do que a narratologia consagrou como analepse e o cinema como flash-back . Se, no momento anterior, M. Carvalho apelava à transgressão, passa agora a argumentar com a convenção literária nos seus ascendentes mais antigos (20-21):

Abra-se aqui uma analepse, que é a figura de estilo mais antiga da literatura, vastamente usada pelo bom do Homero, quando não dormia, e náo sei mesmo se pelo autor do Gilgamesh.

E também a este propósito, M. Anacleto (1996: 108) deixa um apontamento interessante sobre "o recordar da presença contínua de um "texto-palimpsesto" sob uma narrativa autêntica”, um factor de constante fascínio em M. Carvalho. Na tradição das poéticas, reflexóes sobre o sentido e a execução técnica da criação artística, que já desde Aristóteles tendem ao confronto das diversas modalidades de mimesis, literatura e artes visuais (modernamente o cinema) aparecem ligadas pelo mesmo expediente. Arte recente, se comparado com as raízes profundas da expressão literária, o cinema, "deslembrado de Homero ou Camóes" - ou seja, da tradição épica como a primeira criação manipuladora das técnicas de abertura in medias res e do flash-back - julga ter descoberto um recurso, novo e próprio, no que não passava de reabilitaçáo, remoçada, de efeitos conhecidos.

No que pretende afirmar-se como uma escrita própria e autónoma, crítica das opções de outros autores, $\mathrm{M}$. Carvalho não hesita em assumir artificialismos retóricos consagrados e em denunciar, como "estranhas e peculiares tinetas" (21) a sua recusa; com o leitor, estabelece um diálogo de divergência, tanto mais afirmativo da sua liberdade de opção:

Não me ocorre agora nenhum escritor que abomine as analepses, mas deve haver algum. Esse não será, com mágoa minha, leitor deste livro, o que lhe restringe perigosamente o alcance".

E segue-se a tal analepse que, para que se acrescente ao processo o toque irónico, não recua, do ponto narrativo em que se introduz, mais do que

7 Uma simples remodelação do nome para uma mesma técnica; vide Reis, Macário Lopes ${ }^{7} 2007$ : 9, 29-31. Na definição dos autores referidos "por analepse entende-se todo o movimento temporal retrospectivo destinado a relatar eventos anteriores ao presente da acção e mesmo, nalguns casos, anteriores ao seu início". 
escassos "quatro minutos e meio". O factor tempo, associado à analepse, mais do que uma dinâmica narrativa, é neste caso um recurso de efeito caricatural de uma antiga estratégia literária.

Estabelecido o movimento de arranque, o curso da narrativa prossegue sujeito a diversos sobressaltos. Na contracapa, o autor sintetiza os traços nevrálgicos da proposta:

Este livro contém particularidades irritantes para os mais acostumados. Ainda mais para os menos. Tem caricaturas. Humores. Derivaçôes. E alguns anacolutos.

E é exactamente dos anacolutos, de como os manobra M. Carvalho, que faremos uma observação breve. Talvez a velha tradição dramática do deus ex machina seja o exemplo extremo da solução para o anacoluto. Quando tudo parece perdido, quando os acontecimentos, confusos ou incompatíveis, parecem não propiciar um final coerente, um deus virá que, da sua elevada autoridade, terá artes de sanar o problema. Deste efeito o autor do romance não faz também cerimónia em servir-se (59), e não propriamente para selar um desfecho difícil, apenas como arma para justificar um anacoluto. Quando a narrativa, centrada em Joel Strosse, parecia fracturar-se pela intervenção inopinada da Eduarda Galvão, o autor condescende numa suspensáo rápida, para dar, às suas duas personagens, em tempos distintos da narrativa, uma importância similar:

Eduarda tem um destino a cumprir e eu arranjarei maneira de a integrar na história, nem que tenha de fazer sair um deus duma máquina. Por agora traço-a assim, em pinceladas rápidas (...) e vou muito direito à finalidade. Mas lá que a Eduarda faz falta, faz. Depois verão.

Momentos há em que o anacoluto funciona não de ameaça de quebra, eventualmente incómoda, da concentração num episódio ou no desenho de uma personagem. Pelo contrário, pode usar-se como refrigério ou oásis literário, uma espécie de "derivativo de deixar assentar os nervos" (81), para aligeirar o normal curso da narrativa:

Eu sou mais pelas prosas pacatas e defendo-me dos frenesis literários. Hei-de contar o que se vai passando com Eduarda e Jorge, por um lado, e Joel e Cremilde por outro, mas em espairecimento. Agora apetece-me um derivativo de deixar assentar os nervos. Conheceis a Caparica?" 
Mas logo, em outras circunstâncias, a eminência defraudada de um anacoluto pode ser um apelo à coesão da intriga e a justificação da prioridade dada a um episódio relevante; estamos em território de manipulação hábil do processo (98):
Ainda bem que ele não telefonou logo a seguir. Eu lá teria de dar con- ta da diligência e isto ia parecer um romance de fio telefónico. Náo seria má ideia, para outra ocasião, mas, agora, a cadeia telefónica viria introduzir cadências repetitivas, tediosas e impedientes de eu contar o que estou ansioso por ..."

A construção fraccionada da intriga, sujeita a diversos anacolutos, suscita o uso de fórmulas, também ele um processo convencional desde Homero de estabelecer enlaces e fronteiras. Sem se dobrar ao peso da repetição, como era de antiga prática, o autor de Era bom recorre com frequência a frases de encadeamento ou relação entre diferentes tempos ou espaços narrativos:

Já lá iremos. Ora esguardemos como se fôssemos presentes - porque, entretanto, transcorreu a noite e chegou a manhã - a Eduarda Galvão ... (71)

Estas traças previsíveis e banais querem ficar, por enquanto, fora desta história ... (73)

... saiamos rapidamente de Belém, após um olhar reverencioso à Torre, e regressemos a casa do Jorge que já comeu a papa toda, acompanhada por uma banana que é o fruto mais prático de descascar. (74)

Urge agora considerar Joel Strosse que deambula em redondo, na sala, de braços atrás das costas. (113)

Agora reparo que há muito tempo não falo do Joel Strosse propriamente dito ... (135)

Em vez da recorrência a um código de repetição, é a variedade criativa que se usa: a alternância de um português antigo e reconhecível ${ }^{8}$ com o contexto contemporâneo da intriga, o contraste entre o cenário público

8 Fernão Lopes, Crónica de D. João I, cap. CXLIX, Lisboa, Livraria Civilização, I, 309. 
e o doméstico, entre a menção histórica ou cultural e a mais comezinha banalidade. Mas por trás dos diferentes efeitos estilísticos, o objectivo é constante: permitir um anacoluto 'coordenado e consciente'.

De certa forma relacionada com o anacoluto, como quebra no curso directo e regular da narrativa, está a descrição ou écfrase, como um processo marginal, uma interrupçáo descritiva, que $\mathrm{M}$. Carvalho com frequência anuncia. A focagem destes blocos descritivos, com alguma autonomia sobre o fio condutor da narrativa, obedece a conteúdos mais ou menos previsíveis: caracterização sistemática de uma personagem, mas sobretudo descriçóes de espaços e ambientes. Estas eram também já as preferências do romance grego da época helenística?

Da oportunidade de um recurso num determinado momento ou contexto fala o autor de Era bom, a propósito de uma das suas personagens:

Discorrerei agora sobre este desvelo de Florentina Palha, a própria, e matérias afins? Não! Há-de calhar a propósito, quando for ocasião. (28)

A que se associa a consciência do risco de fractura ou incoerência que a écfrase implica:

Entristeceu-se por lhe ocorrerem entretanto pesarosas circunstâncias da sua vida, tão deprimentes que só mais adiante as contarei, para não acrescentar, por agora, disforias à disforia, de que esta secção já vai carregada. (31)

Por isso, um esforço de controle e coordenação entre o contexto e o excurso é cautela nunca excessiva:

Concedamos que Joel tinha razão e recolhamo-nos para alguns tópicos íntimos sobre a decadência desta civilização, mas sem o perder de vista. $(31)^{10}$

9 Estas descriçōes, muito comuns no romance grego antigo, como modelos adoptados nas escolas de retórica, pretendiam demonstrar uma versatilidade enciclopédica. Vide Kirk, D. M. (1960), The digression, its use in prose fiction from the Greek romance through the eighteenth century. Stanford University; Davison, M. (1976), "The thematic use of ekphrasis in the ancient novel", in Erotica antiqua. Acta of the International Conference on the Ancient Novel. Bangor, ICAN; Fowler, D. P. ((1991), "Narrate and describe: the problem of ecphrasis", JRS 81: 25-35.

10 Este é o exemplo da descrição que Hamon, P. (1976), “O que é a descrição?”, in Seixo, M. A. (ed.), Categorias da narrativa. Lisboa, Arcádia: 81 define como "o lugar onde 
Mas é principalmente voltada para a descriçẫo dos espaços que a écfrase cumpriu um percurso diacrónico. Espaços que podem ser, antes de mais, públicos. Se o relato incide num espaço ou edifício concreto, da realidade imediata, claramente identificado, a relaçáo de fidelidade que possa existir entre o modelo e o seu retrato literário levanta o problema do 'realismo'. Com a noção clara de que à ficção é permitida uma liberdade recriativa, uma mimesis flexível, que não se confina a uma reprodução acrítica do concreto ${ }^{11}$, M. Carvalho arreda como inúteis os desajustes que daí possam advir e convida, graciosamente, a realidade a adequar-se à ficção (35):

Se a cadeia de Pinheiro da Cruz não for exactamente assim, convido desde já os Serviços Prisionais a conformarem-se ao texto, ou pelo menos a absterem-se de polémicas incómodas e derivativas do que lhes interessa a eles e a mim.

Mas se o espaço for privado, o mesmo é dizer meramente ficcional, em vez de problemas de verosimilhança outros se colocarão, a dimensão do excurso, como o tipo de pormenor que contempla, por exemplo. O sentido da moderação e do bom gosto é, neste caso, fundamental:

Não disse tudo sobre a mobília, mas acho que ir mais longe era exagerar ... (47)

Eu vou agora explicar como se dispunha a biblioteca, mas não dissertarei sobre labirintos e serei seco e desmunido de alegorias. (135)

E outro tanto se diga se for a personagem o motivo da écfrase (85):

Um escritor estilista dedicaria umas boas três páginas a descrevê-la, com gestos, saltos, risinhos, urros e queda de objectos. Eu por aqui me fico.

\footnotetext{
a narrativa se interrompe, onde se suspende, mas igualmente o espaço indispensável onde se 'põe em conserva', onde se 'armazena' a informação".

11 Halliwell, S. (1968), Aristotle's Poetics. Chicago and London: 16 fala, no que respeita à poesia como também às artes visuais, de representação, como recriação ficcional da realidade, de preferência a imitação, uma concepção mais elementar, que copia, mas não acrescenta, de uma verdadeira criação artística, valor extra, originalidade ou traço identitário.
} 
No anonimato de um 'escritor estilista' vai a alusão a um elemento de estilo, a écfrase. Por natureza extensa, retalhada em pormenores de adorno, de visível redundância e inutilidade, a menção que lhe é feita contrasta com o laconismo de que o nosso autor se afirma adepto. O seu modelo, sem dúvida o bom, porque breve e directo, exprime-se na secura, também paradigmática, de uma outra teorização: "Eu por aqui me fico".

O que, na tradição literária, eram sobretudo cores, dimensóes e formas, dos canteiros do jardim, das linhas de um quadro, de um edifício ou de uma escultura, pode tornar-se, na descriçáo de um ambiente contemporâneo, circunscrito à aridez de 'marcas e proveniências' (82); a loja, o endereço, o fabricante, eis os dados compatíveis com os interesses de um público consumista. Para tal, o nosso autor confessa-se sem talento ou competência, nem sequer vontade de promover aquela 'investigação' que o relato literário responsável requer.

Francamente, acho que estas personagens não merecem que se lhes faça o jeito e o leitor há-de ser poupado àquilo de que se não precisa, porque, tal como eu, se está nas tintas para as emblemáticas comerciais.

Tal como para o anacoluto, esperado mas não consumado, também a écfrase pode ganhar eficácia pela ausência (84):

Eu preparava-me agora para descrever melhor o gabinete do Bernardo, e já ensaiava vários ângulos, com movimentos cinematográficos do olhar, a que não faltava um contrapicado, quando alguém ...

E uma vez mais narrativa e cinema são aproximados por técnicas comuns. Se no caso do flash-back foi o cinema a retomar uma prática já homérica, na descrição ou exposição de ambientes o movimento foi o contrário. Com a sua eficiência visual e capacidade de escolher ângulos de maior sentido estético, é o cinema quem pode contribuir para uma estética retórica despojada e impressionista. Independentemente da dimensão, da perspectiva, da focagem, há que reconhecer que séculos de ensaio e de experiência abonam da importância e mestria da retórica descritiva. Ultrapassando eventuais críticas ou divergências, M. Carvalho aplaude, neste particular, a tradição (119):

Isto merece a sua pincelada, arrenegando daquele célebre teórico que mandava galgar as descriçóes. 
Rendido à sedução da arte de escrever, o autor admite apenas a exclusão de um bom excurso quando o volume de episódios, numa certa fase da intriga, vai já longo e o risco de excesso espreita (166-167):

Ainda bem que naquele dia sucederam a Jorge (...) eventos dignos de mençáo. Náo fosse este um dia em cheio - do ponto de vista do narrador - e lá teria eu de semear acontecimentos pelo livro fora. Assim, posso permitir-me condensar tudo nesta secção ...

Ao controle dos acontecimentos, do seu tempo e do seu espaço, está o narrador omnisciente ${ }^{12}$, uma presença sensível, declarada, interventiva. Colocado acima das figuras que agem no romance, está-lhe acessível a descrição de espaços que nem ele, nem a sua personagem, conhecem. Assiste-lhe o "à-vontade" de imaginar, vencendo os limites da própria realidade (35), um lugar onde nunca nenhum deles penetrou; permite-se devassar a intimidade da personagem e revelar o que o seu Joel Strosse quereria manter sigiloso ("um narrador omnisciente tem as suas vantagens. Se o narrador náo fosse omnisciente não saberia deste particular porque, quando o filho foi detido, julgado e condenado a sete anos de cadeia (...), Joel conseguiu manter um segredo quase total", 35); gracioso 'quase', traçando a irremediável vantagem do narrador omnisciente sobre a personagem. Controla-lhe qualquer movimento ("eu sei onde é que o Jorge Matos estava" (45)); pode navegar entre o passado e o futuro, ou calendarizar cada etapa dos acontecimentos dentro da intriga (82):

... porque enquanto eu descrevi e perorei, já se passaram três horas ...

Ocorre-me que ainda não contei como deve ser o caso do senhor bispo de Grudemil e, enquanto conto e náo conto, o Rover, beneficiando das vantagens do tempo narrativo, ajudado das aceleraçóes do fotógrafo, já irá derrapando por alturas de Alverca. (105)

Além do controle do tempo, dos espaços, da coesão da intriga, o narrador é ainda responsável pelo tom e pela verosimilhança que caracteriza em geral a narrativa. Comecemos pelo tom. Ao elogio que a descrição, mais ou menos extensa, mas sobretudo esteticamente eficaz, já mereceu, M. Carvalho contrapóe o laconismo singelo, rápido, por demais esquelético, a tocar as raias

12 Cf. Reis, Macário Lopes ${ }^{7} 2007:$ 174-177. 
do simples apontamento em alíneas. Talvez a linguagem jornalística tenha, tacitamente, neste padrão extremo a sua responsabilidade (112):

Agora há uma passagem muito rápida em que se contam uns pormenores relevantes que me convém despachar antes de rematar a primeira parte do livro (...). Se não fosse abusar, até usava alíneas e limitava-me a substantivos.

Tais excessos parecem convir a um estilo pós-moderno, o da geraçáo do correio electrónico e das SMS (112):

Mas como costumo ficar incomodado das habilidades modernaças, armadas ao pingarelho, com que a minha concisão poderia confundir-se, forço-me, por disciplina, a debitar texto, embora escasso.

Por outro lado, a tentaçáo de sobrepor convençóes parece, por vezes, irresistível. A condução perigosa de um repórter, fanático de aceleraçóes e derrapagens, insinua no narrador o deslize para outro contexto, o da "criminalidade literária" (104). Entre as duas situações, a diferença é tão só de grau. O escuro da estrada e o reflexo dos faróis nas árvores sugerem um "ambiente tétrico"; nos ramos, a imaginação projecta "mãos vegetais, nodosas, aduncas, malfazejas"; o ruído do motor talvez abafe imaginários "uivos agoirentos ou uma gargalhada de estalo". Neste contexto, a tentação progride no narrador "omnipotente" (104):

Boa ocasiáo para eu dar cabo da Eduarda e já agora do fotógrafo que, também, não se perdia grande coisa.

O cinema regressa como parceiro natural da narrativa literária, colocadas ambas as artes perante o factor 'verosimilhança'. Já Aristóteles (Poética $\left.1451^{a}-1451 b\right)$ se apoiava na verosimilhança para estabelecer um contraste entre poeta e historiador:

É evidente que a função do poeta não é contar o sucedido, mas o que podia suceder e o possível em virtude da verosimilhança ou necessidade (...). O historiador narra o sucedido e o poeta o que poderia suceder.

É, de certa forma, com palavras equivalentes às da velha Poética que M. Carvalho recorda a regra da 'verosimilhança', mas para sublinhar quanto a 
realidade por vezes excede a ficção no seu capricho; numa subversão entre 'realidade' e convenção literária, escreve (84):

O que eu passo a contar agora é inacreditável. (...) A vida, não raro, ficciona, devaneia, absurdiza e eu hei-de conformar-me a ela mais do que ao famoso pacto de verosimilhança outorgado com o leitor. ${ }^{13}$

A verosimilhança pode retratar a realidade, salvaguardando no entanto a vantagem de escamotear alguns dos problemas que lhe perturbam o curso e, por isso, "programando" as etapas da história isentas de inúteis embaraços. Outro tanto faz a arte parceira, o cinema, deitando máo de recursos semelhantes que abreviam e aplanam a narrativa, ainda graças à omnipotência do autor (94-95). Enquanto, no cinema, "os automobilistas encontram sempre um lugar a jeito para estacionar, mesmo no centro de Lisboa", também "o autor totalitário" tem artes de garantir que "as pessoas estão sempre em casa quando são precisas" e assim se poupa a pormenores desnecessários e ao seu leitor algum enfado:

Imaginem as voltas e o esforço em que eu me veria enrolado se o Nunes não estivesse disponível. Teria que repetir telefonemas, encontrar mais situaçóes, mais ambientes, mais pretextos, mais conversa e enquanto assim ia gastando o papel, com ele iria gastando também a paciência do leitor, que participa da natureza dos bens escassos.

A compensar excursos e delongas, o autor de Era bom insiste na vantagem do laconismo e da narração enxuta. Mas o inverosímil em literatura pode ir, naturalmente, muito mais longe do que o simples garantir da eficácia e brevidade do relato; pode exactamente proporcionar o efeito contrário, com a introdução do elemento fantástico, correlato com um aparato estilístico condizente. O sonho - com toda a sua convenção que vem da épica mais tradicional, a homérica, ganha fôlego com o teatro antigo, sobretudo trágico, e não deixa de penetrar géneros posteriores como a já mencionada novela grega da época helenística - constitui um bom

13 Scodel, R. (1999), Credible impossibilities. Conventions and strategies of verisimilitude in Homer and Greek tragedy. University of Michigan Press:1-31 distingue entre verosimilhança e credibilidade; no primeiro caso, a autora fala da conexáo que o texto cria com o que o destinatário entende por realidade; por credibilidade, por outro lado, exprime-se a aceitação que o público tem de assumir a convenção, as regras do género, o que torna consumível a ficção. 
exemplo de 'inverosímil'. Conhecemo-lo, como um processo de introdução do sobre-humano, como profecia de futuro, como retrato da consumação de um destino temível. No contexto literário, o sonho tem, em geral, um duplo efeito: o de desencadear sobre quem o recebeu uma reacção emotiva, e o de preparar o leitor / espectador para o desenvolvimento previsível da acção. A sua expressão comporta sempre uma narrativa, a da visão tal como ela se revelou, com todos os factores de ambiguidade que lhe são próprios, seguida de uma tentativa de interpretação. Ao lado das profecias ou dos presságios, o sonho faz parte de um código de sinais que transmitem do além a vontade dos deuses ou do destino.

$\mathrm{O}$ sonho, como o vislumbra $\mathrm{M}$. Carvalho, é contrário à melhor tradição antiga, onde o misterioso e o transcendente que lhe estão na natureza convêm mais ao ambiente recolhido da noite e à privacidade do leito. Porque rodeado de silêncio, de solidão e de treva, o ser humano tem melhor capacidade de percepçáo, todo concentrado que está sobre a mensagem que o aborda. Por isso a visão, como um raio de luz em plenas sombras, contrasta com o ambiente em volta e estimula a famosa dicotomia trevas / luz, com todas as conotaçóes objectivas e subjectivas inerentes. A reacção do sonhador é constante, impóe a comunicação, exige a confidência, necessita de um intérprete. Em geral, os sonhos têm uma forte componente visual, exprimem-se por imagens sem palavras, mas capazes de falar pela expressividade dos símbolos que usam. Sáo, portanto, apelativos ao sensorial, breves na comunicação, valorativos apenas de alguns elementos sobre os quais retêm a atenção do seu destinatário. Mas primam pela ambiguidade, sobre que o espírito é chamado a pronunciar-se face às aparências captadas pelo sentidos ${ }^{14}$. A M. Carvalho é o seu contorno fantástico, mais do que a simbologia de que o sonho é portador, o que lhe suscita o comentário (33):

Vinha a calhar agora um sonho, com multidóes, cânticos e bandeiras e umas irrupçóes disparatadas (...), para dar verosimilhança ao sonho que, por definição, é inverosímil e portanto só com inverosimilhanças é que se aceita, embora as verosimilhanças que vão de par com as

14 Sobre a potencialidade dramática dos sonhos, vide Devereux, G. (1975), Dreams in Greek tragedy. Oxford, Basil Blackwell; Lévy, E. (1983), "Le théâtre et le rêve: le rêve dans le théâtre d'Eschyle", in Zehnacker, H. (ed.), Théâtre et spectacles dans l'Antiquité - Actes du Colloque de Strasbourg. Leiden: 141-168; Pereira, S. M. (2008), "Poética dos sonhos e das visōes em estado de vigília - I", Humanitas 60: 11-28; idem, "Poética dos sonhos e das visóes em estado de vigília - II", Humanitas 61: 5-18. 
inverosimilhanças estejam carregadas de sentido e de piscadelas de olhos, quando não são as inverosimilhanças que batem certo com os dicionários de símbolos de que, por acaso, nem tenho nenhum exemplar à mão.

\section{$\mathrm{O}$ retrato e a acçáo das personagens}

A par das estratégias narrativas, o autor tem de preocupar-se com o desenho das personagens, os agentes da acção. Também Aristóteles (Poética $\left.1451^{a}-1451 b\right)$ lhes reconheceu a importância e doutrinou sobre a sua criação:

O universal - que é próprio da poesia e da ficção, acrescentamos nós - consiste em estabelecer a que tipo de homem corresponde dizer ou realizar tais ou tais coisas em funçáo do verosímil e do necessário, um objectivo a que a poesia aspira apesar de impor nomes próprios às personagens.

Sublinha Aristóteles o carácter paradigmático da personagem, que mantém a universalidade de um tipo oculta por trás de um nome, que, no âmbito da ficção, a individualiza. Há depois a compatibilidade - ou 'verosimilhança' - a observar entre o tipo e a acção e palavras que lhe são atribuídas. Assim se define, no essencial, a 'veracidade' da personagem.

Importa, em primeiro lugar, escolher as personagens que melhor convêm a um enredo. $E$, aí, a convenção de muitos séculos tem uma palavra a dizer. Desde sempre, a tradição privilegiou a personagem num determinado contexto, familiar e social. Assim o ressuscita M. Carvalho (26):

Habitualmente ocupamo-nos de histórias de famílias, avôs, tios, primos, cunhados, uns bons, outros maus, cartas antigas a forrar baús, mansôes vetustas a que se regressa e essas coisas ...

A estratégia fica patente: figuras múltiplas, unidas pelo parentesco, e sobretudo contrastantes, pela maior ou menor proximidade familiar, por condicionalismos éticos e etários, ou de género, a justificar conivências ou conflitos. O movimento tradicional do nostos, o regresso à "mansão vetusta" que é o ponto de referência da acção - esquema de que a Odisseia é o primeiro marco na literatura da Europa -, como também a carta, a 
permitir contacto, aproximação ou reconhecimento ${ }^{15}$, são elementos que a tradição usou sem esgotamento neste jogo de interacções. À tradição, porém, M. Carvalho responde com a necessidade de refrescamento, de renovaçáo, que aproximam o agente da acção do leitor e tornam, por isso, os acontecimentos mais próximos, perceptíveis e mobilizadores (26). Estamos num terreno equivalente ao que Eurípides proporcionou, na reformulação que também ele fez, na tradição trágica, do elenco de personagens, o dos oikeia prágmata (Aristófanes, Râs 959), 'temas caseiros', porque envolvem parentes e porque são 'familiares' ao espectador.

... e esquecemo-nos de passar pelas ruas, com atenção penetrante, e deixar à posteridade uma nota de verismo bem documental.

À tipologia do factor humano, que tende a ser contínua e, no essencial, eterna, o contexto pode trazer a tal veracidade e actualização. Por mais ficcionais que as figuras de Era bom sejam, mesmo se passadas por um banho de modernidade, tornam-se presentes e palpáveis na moldura da bem conhecida Costa da Caparica. O real próximo e a ficção sobrepóem-se em perfeita harmonia (81):

A Costa atrai um bom número dos nossos concidadáos que adoram aquilo. Imaginai-os a cirandar por lá, do modo palonço que foi descrito, e as nossas personagens fazendo vida entre eles.

Dos modelos convencionais, o autor de Era bom arranca um exemplar famoso, o par do velho / jovem, pai / filho (40):

Quando um homem de cinquenta anos se póe, inevitavelmente, a deitar contas à vida e a considerar com melancolia que na Idade Média ou na Antiguidade seria já um anciáo provecto à beira da cova ...

A menção explícita do passado vem datar o exemplo com milhares de anos. Dessa tradição, muitas vezes fundamentada no que reconhecemos como 'conflito de geraçôes', M. Carvalho valoriza sobretudo a continuidade;

15 Sobre a tradiçáo literária da 'carta' desde a literatura grega antiga, vide Silva, M. F. (2008), "Mensagens, cartas e livros no teatro grego antigo", in Matos, M. C. (ed.), Helénicos. Estudos em homenagem do Prof. Jean-Pierre Vernant (1914-2007). Lisboa, Edições Távola Redonda: 227-260. 
e, dentro de um espírito com raiz na literatura da Grécia Antiga, sublinha a ideia da caducidade da vida, da finitude da criatura efémera que o ser humano é, por natureza e destino; e é essa efemeridade que os filhos ajudam a combater como "procuradores e mandatários da progenitura" (40). Esta é ainda a ambição do Joel Strosse, personagem central no romance em análise.

Feita a escolha, segue-se o desenho que, na literatura ao contrário de artes mais ligeiras, de traços leves, como a banda desenhada por exemplo, exige "espessura" (124). Objectivo esse que se pode atingir por diferentes caminhos. Dar voz e movimento às próprias personagens será, certamente, um deles, consentâneo com o drama, mas a que o romance deu continuidade. Outro será sobrepor-lhes a tal "omnisciência" do autor e esquematizar, como em retrato a que se irá conferir um sopro de vida, as suas linhas de força como preâmbulo à acção (18); com Rui Vaz Alves e Joel Strosse Neves na sua mira, e depois de proceder, entre ambos, a uma hierarquização a que não falta ironia - "Rui Alves é vogal da administração e dirige o "departamento de contacto" da casa; o outro chama-se Joel Strosse Neves, e estancia habitualmente num dos pisos de baixo e tem, sobre o primeiro, a única vantagem de ser o protagonista desta história" -, M. Carvalho afirma-se como narrador responsável pela apresentação das personagens:

Como, neste breve relance, os dois homens estão apenas a olhar um para o outro, e náo adiantam nada, eu aproveito a ocasiáo para me prevalecer de uma velha tradição literária e apresentá-los ao leitor, com o acrescento de umas circunstâncias esclarecedoras.

"A velha tradição literária" que o autor invoca para a descrição das personagens pode recuar até à mais antiga épica europeia, consagrada sob o nome de Homero; mas virá a ter, no romance helenístico, uma reconhecida expansão. A mesma técnica, que permite desvendar intençôes e sentimentos ocultos das personagens, tem expressão em fórmulas, como "eu entretanto vou-lhe cortando na casaca” (95), a preceder a apresentação descritiva da figura.

O grau de "espessura" da personagem depende também de uma opçáo do autor e M. Carvalho decide por o que se poderia chamar um padrão impressionista: pôr de lado excessos descritivos para se centrar nas linhas de força de um retrato, eis a opção que reiteradamente assume:

Por agora, traço-a assim em pinceladas rápidas, de zarcão, despachadamente, não me atardo nos pormenores, prescindo das espessuras, não me distraio com as cores e as luzes e vou muito direito à finalidade. (59) 
Eu não queria entrar muito em pormenores psicológicos, porque tenho pressa, e prometi não aprofundar em excesso esta figura, mas talvez não seja despiciendo sublinhar aquilo que já está percebido ... (61)

Esta sobriedade na descrição é, sem dúvida, uma porta aberta ao agir e falar da personagem, de modo a que o leitor tire, por si, conclusóes.

Criada a figura, há que imprimir-lhe vida, acção e também interacção. Mais do que agir, a personagem integra-se num todo, onde deve também interagir. E essa articulação, de que depende o fluir da intriga e a consolidação de sentidos na narrativa, é vital no romance (67):

E assim se estabeleceu o contacto entre Eduarda Galvão e Jorge Carreira Matos, aprestando-se uma ligação nesta história, que já nela tardava.

Mas uma outra interacção é habilmente consciencializada, entre o autor e a personagem. Por vezes, entre ambos parece gerar-se uma intimidade, que os aproxima e sentimentalmente os envolve (114):

Baixo a guarda, mudo de registo, vem-me até à ideia interpelá-lo e tratá-lo, por instantes fugazes, na segunda pessoa do singular.

O espaço da ficção parece então reduzir-se e permitir que, "do seu Olimpo", o autor penetre no próprio contexto intradiegético. Numa focagem que tudo tem de 'fílmico', o autor procura o melhor ângulo de observação:

Deslizo cá do meu Olimpo e instalo-me por ali, naquela sala pelintra, talvez junto ao canto superior esquerdo, encostado ao tecto, ao lado da empena, que é sítio azado para tudo ver, pese embora a mancha de humidade.

Mas mais não pode o seu esforço do que observar de perto e atentar particularmente na personagem. A distância que os separa - realidade / ficção, narrador extra e intradiegético / personagem - é intransponível.

Apercebo-me de que é inútil querer chegar ao contacto com o Joel Strosse. A minha voz não seria ouvida, as minhas mãos atravessá-lo-iam, como as de um fantasma (...). Tenho de limitar-me a perscrutar, a conjecturar, a espantar-me, sentindo-me, porém, mais próximo dele, 
do que nesta frieza neutra sentado à minha secretária. Joel existe, eu não. Com este estado de coisas me hei-de confortar.

E atingimos o cerne da questão, aquele momento em que o autor dá autonomia à personagem e lhe inspira gestos e palavras. A coerência é então uma imposiçáo; definido um tipo humano, todos os comportamentos que se lhe atribuam devem obedecer a uma compatibilidade convincente. Que o autor reflicta sobre possíveis reacçóes da personagem num dado momento e justifique a sua opção é o reconhecimento dessa mesma regra (78):

Dramático e surpreendente! Se fosse ocasiáo de mordacidades ter-lhe-ia respondido Jorge no espírito dos tempos. (...). Porém, Jorge não era mau tipo, como eu, de resto, já preveni umas páginas antes, de maneira que optou por um regozijo moderado.

Há momentos em que é no silêncio, melhor do que em qualquer outra manifestação, que a expressividade do episódio assenta. De efeitos reconhecidos desde a Antiguidade, o silêncio contém um potencial de expressóes ambíguas - luto, temor, sofrimento -, que, em última análise, impóem o corte com a realidade em volta ${ }^{16}$. Mas nem por isso falta à mudez da personagem um interlocutor, na pessoa dos que a cercam (dentro da ficção) ou a observam (dentro e fora do contexto narrativo), incentivados à surpresa e especulação sobre o enigma que o silêncio contém. É esse o desafio que M. Carvalho coloca ao seu leitor, esgrimindo com um processo que continua vigorosamente actual (77):

Houve um silêncio comprido que eu náo sei como qualificar. Talvez, em explicando como as personagens se encontravam e o que faziam, possa alguém, mais hábil que eu, encontrar a qualificação para o silêncio que é, da Língua Portuguesa, a palavra mais difícil de adjectivar novamente.

"Comprido" é o qualificativo imediato, que assinala a característica mais evidente e constante do "silêncio", literário ou dramático. Mas, além

16 São sugestivas as palavras de Várzeas, M. (2001), Silêncios no teatro de Sófocles, Lisboa: 12, sobre o assunto: "Podemos considerar o silêncio um signo pertencente ao código retórico-estilístico, que funciona como uma espécie de grau zero da linguagem, com idênticas potencialidades expressivas. Idênticas ou até superiores, visto que suscitam uma emoção específica que as palavras não são capazes de produzir da mesma maneira, com o mesmo carácter de contenção e urgência, digamos assim". 
da evidência superficial, é na profundidade e amplo espectro psicológico que a fluidez é grande e os qualificativos múltiplos e indefinidos.

À convenção do silêncio opõe-se a da linguagem. A modulação que lhe é exigida constitui um factor relevante como veículo de nuances emotivas de cada figura em concertação com o contexto variável em que se encontrem. Sem quebras ou incoerências, essas variaçóes respiram naturalidade e persuasão (81):

Já vejo que estas personagens estáo num momento miudamente agitado das suas vidas. Os acontecimentos provocaram-nas e transtornaram-lhes o natural de hábitos e de pensamentos.

Mas há também, em consonância com a permanência de traços que a noção de 'tipos' humanos contém, uma convenção de linguagem; dessa, o atractivo reside no próprio reencontrar de fórmulas conhecidas ou até mesmo desgastadas, que se tornam transversais sob diferentes modalidades artísticas (113):

Esta discussão, infelizmente, não brilha pela originalidade. Fiz um traslado das objurgatórias que os casais da classe média, possuidores de automóvel, costumam trocar pelo menos dez vezes na vida. Acho que até há uma ópera sobre o assunto.

Por fim, inerente ao maior ou menor aprofundamento de cada retrato e ao mais ou menos dilatado espaço concedido a cada personagem, resulta a noção de figura primária - o protagonista - ou secundária. Ao protagonista cabe, por tradição, uma presença e actuação constante, que o identifica com o próprio fio da acção. Quando a diversidade de outras figuras ou episódios parecem, por momentos, arredá-lo da ribalta, uma reflexão do narrador pode contribuir para repor a hierarquia esperada (135):

Agora reparo que há muito tempo não falo do Joel Strosse, propriamente dito, que eu quis que fosse personagem capital nesta história e que tem sido sobremaneira negligenciado. Por onde andava ele?

Mas um outro traço, primário no esboço de cada figura, contribui também, soberanamente, para estabelecer distinçóes: o nome. A escolha de um nome para cada personagem é, em M. Carvalho, uma estratégia visível. Nomen omen - diziam os antigos - 'o nome é um presságio'; 
e esse continua a ser um pressuposto vital na narrativa do autor português. Mas se esta preocupação é, em si mesma, uma evidência comprovada por múltiplas opçóes - reveladoras de vulgaridade ou especificidade -, um comentário testemunha o que mesmo ao leitor mais desatento náo passa despercebido (87):

... a filha do Jorge, que aproveito para informar chamar-se Eufémia, nome cuja escolha não fora inocente.

Mais do que as ressonâncias etimológicas - Eufémia, 'a bem falante' -, são as conotaçóes políticas - a lembrar a célebre revolucionária, Catarina Eufémia - as que se patenteiam na escolha. A preferência ganha sentido se lembrarmos que o pai, o Jorge Matos, "esteve preso pela PIDE em 1973 e sofreu tratos de polé" (47), o que o incentivou a tornar-se um activista, "inventor de um método absolutamente inovador de colagem de cartazes" (47). Mesmo se superficial nas suas convicçōes, a tendência para se afirmar por exterioridades justifica também a escolha do nome para a sua herdeira. Mas, se atributo oportuno no retrato paterno, "Eufémia" é nome possuidor de uma tremenda ironia, se considerado o carácter da sua portadora, "dada em beata, missionária em São Tomé" (45). Por isso, o mesmo pai que a baptizara augurando-lhe revolucionário futuro de inconformismo, procurava diluir-lhe tendências tão claramente conservadoras sob uma referência ambígua (87): "Jorge apressou-se a dizer que ela estava colocada em São Tomé, numa missão internacional": fórmula de uma ambiguidade muito mais promissora e estimulante de prestígio.

Em contraste com a impressão produzida pelo nome está o resultado, não menos efectivo, do anonimato. Este pode ser articulado com a natureza de uma personagem secundária, aquela que não detém mais do que um lugar obscuro. É o caso do "professor de Grego", uma brilhante construção de M. Carvalho (153):

Então aquele professor de Grego não tinha nome? Acho que já o vai merecendo, pelo seu esforçado protagonismo, a querer à força entrar na história. Como é que ele se há-de chamar? Pensando bem, fica-lhe a calhar Vasco Reboredo, mas não há-de passar além de seis páginas, se tanto, embora exemplares.

Com o protagonismo pontual que lhe é afectado, prioridade num episódio mesmo que de dimensão comedida, a figura sai do simples anonimato 
tipológico - qual Ama, Mensageiro ou Servo da antiga tradiçáo - para assumir maior autonomia e "espessura" e, por essa via, reclamar um nome. E esse, conservador, com laivos de excepção, é o que melhor convém à figura exótica do professor de Grego.

\section{O domínio da linguagem}

De entre o que pode chamar-se 'lugares comuns', o cliché mereceu a A.-M. Perrin-Naffakh ${ }^{17}$ uma definição simples e apropriada: "O cliché é - na linguagem, nas artes, nas ideias e nos costumes - o espaço de opçôes reveladoras entre tradição e inovação". Configura-se como uma ideia convencional, provinda do passado, que uma sociedade tende a repetir, sob forma de uma expressáo institucionalizada e estereotipada. E. Rabaté ${ }^{18}$ pode ainda concretizar, apelando agora à forma do cliché: "Pertence, antes de mais, à língua comum (...); é, além disso, um fragmento de língua morta, desvitalizada, ou pelo menos adormecida (...); é, por fim, característico de uma língua fixa, que conserva, como palavras congeladas, antigas figuras e possui (...) uma rigidez ameaçadora”. Mas nesta sua vulgaridade e fixação, o cliché está aberto à criatividade literária, em primeiro lugar como alvo de caricatura, mas também como fonte inspiradora para reformulaçóes ou glosas ousadas. Conclui, com pertinência, G. M. Rio-Torto" ${ }^{19}$ " “...o cliché é ao mesmo tempo fonte e manifestação de criatividade e cristalização”.

Em Era bom, o lugar-comum tem o seu espaço de prestígio e uma versatilidade bem explorada, de que o primeiro sintoma, tardiamente justificado, está no próprio título do romance (160):

Eis a Vera Quitério ao telefone (...). Vai dizendo "hum-hum, hum-hum..." e anotando, sisudamente. De vez em quando fala e declara: "pois, pois, era bom que trocássemos umas ideias sobre o assunto ...". No decorrer da presente conversa, ora isoladamente ora no meio de outras frases que pouco interessam, esta expressão surgirá repetida. É aquilo a que metaforicamente, na prosa fradesca, se chama "um bordão de linguagem". A ele voltarei porque, dando o título ao livro, merece alguns desenvolvimentos.

\footnotetext{
17 (1996), "Le langage cliché: aveu d'usure ou pouvoir d'écho". Confluências 14: 7.

18 (1996), "Henri Michaux et le cliché: résistance et fascination”. Confluências 14: 62.

19 "Linguagem e clichê", Confluências 14: 160.
} 
Associado à frase, M. Carvalho anuncia "o bordão de comportamento" $(160,162)$, ampliando a palavra repetida com o gesto mecânico de tomar notas, traços caracterizadores de uma secretária. Por enquanto, o idiotismo é ainda e tão só a repetição atípica, expressiva de uma rotina falha de imaginação ou de criatividade. Mas desengane-se o leitor e aguarde, adiante, o desenvolvimento prometido; porque não só não se trata do repetir inconsciente de um dito comum, como exigiu à sua autora, a Vera Quitério, uma aturada elaboraçấo. Como quem conhece bem os caminhos a percorrer para conseguir expressóes cristalizadas, M. Carvalho atesta a originalidade da sua personagem (165):

Eu já fiz uma detalhada investigação sobre a matéria dos auxiliares de frase, recolhi milhares e milhares de expressões, consultei alguns tratados, nacionais e estrangeiros, e ainda náo encontrei referência a alguém que usasse um "bordão" tão arrevesado, nem explicação para o mesmo.

Da construção de fórmula tão estranha nos dá conta o autor. De um simples e bem alentejano "n'é?", "nasalado e musical no final das frases", um banho de capital partiu à recuperação de um pleno "não é verdade?", que flutuou com um "não sei se estás a ver?", ou, ainda melhor, "não sei se estás a apreender a ideia?". Na fuga a que se propóe da banalidade rasteira, a Vera Quitério investe com efeitos socializantes e com um esforço de conformação profissional, que o autor escalpeliza. Primeiro a suavização do que pudesse soar a uma impertinência descabida: "Estou em crer que a bondade natural da Vera acabou por achar aquele "há que discutir" demasiado imperativo no "há que", e demasiado conotativo de desavença no "discutir". O subconsciente dela deve ter amaciado o "há que", sobremaneira seco e autoritário para um mais urbano "era bom"'; depois a tentativa de evitar qualquer confronto verbal: "”Era bom que discutíssemos" poderia, talvez, dar a ideia de desafio para uma boa zaragata. De maneira que Vera há-de ter preferido o eufemismo do "trocar ideias"; faltava-lhe o necessário complemento e daí o "sobre o assunto"”. Eis o milagre do surgir de um bordão, onde se mesclam sensibilidade, rigor profissional, imaginaçáo, polimento, que podem transformar um simples "n'é?" em algo realmente criativo e pessoal: "Era bom que trocássemos umas ideias sobre o assunto". Podemos, com esta liçấo de linguagem, perceber quanto, a partir do enunciado imediato do título, a expressáo e o estilo estấo nas prioridades do autor do romance. 
É no plano lexical que a estabilização do lugar-comum assenta; depois de condicionar o nome, fixa, junto dele, o qualificativo ou epíteto. A raiz do processo pode estar num uso que suscitou atenção e popularidade; veja-se o exemplo sugestivo do epíteto, que se pode tornar logótipo, de uma cidade. Foi de um cineasta suíço que Lisboa ganhou o estranho epíteto de "cidade branca" 20 , "confundindo-a porventura com Évora, ou com Campo Maior" (16). Apesar de desajustado à realidade, o qualificativo beneficiou da liberdade devida aos criadores (17):

Aqui há que condescender com convicções entranhadas, tolerar as daltonias íntimas, garantir a liberdade poética, libertas uatum.

Liberdade de que beneficiam os criadores de arte em geral, não apenas os cineastas, mas com certeza também, em graus diferentes, os escritores. Ou não terá João de $\mathrm{Melo}^{21}$, autor de ficção, num dos seus livros, o direito de asseverar que "o mar é branco", sem que haja direito a corrigi-lo com um "branca é a espuma"? O que poderíamos chamar 'opiniáo criativa', na atribuição de um epíteto visual, detentora do direito de confundir o objectivo - Lisboa não é branca - com o simbólico - mas é, tal como Évora ou Campo Maior, símbolo de um sul com traços mediterrânicos -, influencia a 'opiniáo colectiva' e pode impor, como estereotipada, uma forma de narrar (16):

As pessoas comuns têm destas coisas ... Deixam-se levar pelas declaraçóes de gente prestigiada, mesmo quando a gente prestigiada se deixou iludir por impressóes fugidias e sacudidas pela sequência de fusos horários ...

20 A aproximação entre a literatura e o cinema é frequente em Era bom (cf. 183-184). A incapacidade que as palavras denunciam em certas circunstâncias é facilmente suprida pelo poder, outro, da imagem e do som. E quando as duas artes se associam ou sobrepóem, há que proceder aos inevitáveis ajustes (184): "Se fizerem um filme deste romance quero-o, nesta passagem, expressionista, de estúdio, cheio de efeitos, com muito papel pintado, e habilitado a palavras sagazes dos Cahiers du Cinema, ou de quem quer que os substitua".

21 João de Melo, nascido nos Açores em meados do século xx, tem dedicado a sua atençấo literária sobretudo ao romance e ao conto. Muito marcado pela experiência de uma campanha em África em tempos de guerra do Ultramar, tornou este um dos motivos fortes na sua criação, a par de elementos dedicados aos Açores, sua terra natal. $O$ meu mundo não é deste reino (1983), Autópsia de um mar de ruinas (1984), Entre pássaro e anjo (1987), Gente feliz com lágrimas (1988), contam-se entre os seus títulos mais conhecidos e premiados. 
Fascinada pelo impacto da fórmula, afinal obra de "um autor fatigado", a multidão cede ao atractivo das palavras e mergulha, sem crítica, na própria ficção:

Há gente a reparar no título que não na fita, e a olhar em volta, ninguém.

Simples elementos de superfície são consumidos como indícios de profundidade intelectual, quando se trata de mero aparato, tendencialmente instável e caduco. Logo o epíteto "branca" se confronta com outro, consagrado por uma tradição mais longa, "cidade de mármore e granito", ao mesmo tempo que uma anónima gente prestigiada ganha nome, Alexandre Herculano $^{22}$. A ironia é neste caso tanto mais forte quanto o perfil literário de Herculano o vincula particularmente com a história, o que lhe exigiria um mais estrito respeito pela verdade. Também Herculano se deixou arrastar "por uma imaginação romântica", e pôs mármore e granito onde nunca existiram. Mas nem por isso deixou de consagrar a expressão num tempo datado, um século e meio, que divulgou, repetiu, fixou a expressão que pareceu, esteticamente, feliz. Em diferentes contextos, públicos e privados - "nos discursos oficiais, nos arrebatamentos de bodas e baptizados, na retórica de alguns professores de liceu, e na conversa dos anciãos ao adormecer de netos" -, as palavras de Herculano foram acriticamente repetidas, como fórmula feita ou palavra passe de uma certa época ${ }^{23}$. Primeiro oficial, progressivamente mais popularizada, a expressão repetida decai e fociliza-se, como antiquada. Escapa-se-lhe então o colorido literário e avulta nela o desajuste prosaico. Para salvaguardar, mesmo assim, a respeitabilidade do secular historiador, M. Carvalho condescende até em reconhecer, entre os tons diversos da cidade, "as suas brancuras aqui e além, preciosamente colocadas, para servir o todo" (17). Numa palavra, o diálogo entre a realidade e a criação literária faz-se a vários níveis, dentro de uma tradição mimética de que Aristóteles é um primeiro testemunho (vide supra 10-11). Arriscando, por sua vez, um novo epíteto, M. Carvalho, com a liberdade que lhe dá o estatuto de autor de romance, avança com o "magenta", uma cor, de resto, muito do seu gosto literário ${ }^{24}$. E defende (17):

22 Expressão usada em $A$ voz do propheta (1837), mais tarde reeditada em Opuisculos (1873).

23 É o que Perrin-Naffakh 1996: 10 refere como "certos tipos de linguagem que uma época ou um meio póem em moda durante um tempo".

24 Que consagrou, mais recentemente (2008), no título de um romance, A Sala magenta. Lisboa, Caminho. 
O que importa asseverar agora é que, ainda que a cor magenta não venha nos dicionários, o que quase a candidata à inexistência, lançada naquela rua, desmerece tanta gritaria e ignorância.

Reserva-se, assim, o autor a liberdade de ir além de uma linguagem padronizada. E decerto, como com o cineasta suíço ou com o historiador Herculano, também o seu magenta - tão ficcional como o branco, o mármore ou o granito - há-de colher os seus adeptos e conhecer a fixidez, em todas as vozes e monitores, totalmente popularizada (17):

Alto, que querem pintar de cinzento o célebre prédio magenta da rua tal ...

Deixemos a linguagem da arte e passemos à do simples quotidiano, onde o cliché prevalece. Alguns incrementos de estilo se associam à insistência repetitiva. Assim a hipérbole, que condimenta uma frase de ruptura afectiva como "o meu filho, para mim, morreu" (41). Em consonância com o que afirma P. Jourdan ${ }^{25}$, que não convém a um narrador talentoso reproduzir, de modo passivo, um cliché, também M. Carvalho recusa a frase convencional, obtendo um efeito paródico da própria suspensão (41-42):

Quase chegou a proclamar "o meu filho, para mim, morreu", mas conteve-se a tempo, ao perceber a teatralidade ridícula do lugar-comum e a falsidade dele.

Frase aliás vazia, em conflito com a realidade, "porque a fotografia de Cláudio lá continuava na Fundação sobre a secretária”.

Num contexto mais literário, "mede a sala a grandes passadas", (50) propóe uma solução déjà vue, verdadeiro tormento de quem se deseja criativo e original:

Mas francamente, receio que o leitor já tenha lido isso em qualquer lado. A quem escreve, faz sombra essa barreira constante, eriçada de farpas, daquilo que outros mais expeditos ou temporãos escreveram antes.

É essa a fronteira que separa o cliché, fixo e gasto, da capacidade de inovação. Para evitar um plágio desconfortável, o autor terá de empenhar-se

25 (1996), "Paul Valery chasseur de perroquets", Confluências 14: 51-59. 
no achado dos seus próprios lugares-comuns, fórmulas que, desde a épica homérica, apoiam a contextualização repetida de espaços, tempos figuras e suas características e acessórios. É no adjectivo que a excelência do processo assenta; o que opor a uma noite "cerrada, fria, tempestuosa", epítetos convencionais de um ambiente hostil e agoirento? Porque afinal sombras tais náo estáo previstas nesta narrativa, com isso se esvai a necessidade de inovar o epíteto ou de se adoptar uma fastidiosa repetição. É do mesmo adjectivo que surge o indesejável cliché no seu uso mais puro, aquele em que, alheado de qualquer sentido ou contexto, o qualificativo é accionado a propósito e despropósito. Nesse risco mergulhou a Eduarda Galvão, a periodista, fanática de um blasé que pronunciava (58)

com generosidade, aplicando-o a um universo de realidades, largamente excedentário do campo semântico competente. Considerou blasés o fotógrafo, o proprietário, o rapazito vestido de encarnado que ia levar pizzas à hora do almoço, e o cachorro de um vizinho que se equilibrava nas patas de trás.

Parece ser da natureza do lugar-comum o desgaste, mesmo quando criado expressamente pelo próprio autor. Em breve, o seu destinatário se dará conta da repetição, que lhe soa, já não a criação recente, mas a pura incapacidade (67):

E só não exclamou "o vinho está tirado, há que bebê-lo", porque eu já gastei a expressão umas linhas acima. ${ }^{26}$

Com o estilo colaboram algumas figuras de estética literária a que $\mathrm{M}$. Carvalho não se furta, ciente do efeito da tradição na expressividade. A metáfora surge, no catálogo, referida como recurso de excelência ${ }^{27}$. Em primeiro lugar, com a sua formulação própria - um "como" a anunciá-la

26 Vide 66.

27 Trata-se, de facto, de uma figura de estilo muito antiga, que Aristóteles, Poética 1457 b 6 define como "a transferência de uma palavra que pertence a outra coisa" (tradução portuguesa de Valente, A. M. (2004), Aristóteles. Poética. Lisboa, Gulbenkian), ou, mais adiante (1457b 13), "aplicar a uma coisa o nome que é de outra”. Já o autor da Poética $1458^{a}$ 20, considera também a metáfora como uma defesa contra a banalidade da linguagem e uma protecção contra o que é simplesmente corrente. Mas alguma parcimónia no seu uso (1458b 13) protege o discurso do ridículo. De entre os ornamentos de estilo, a metáfora é, em particular, "sinal de talento, porque construir bem uma metáfora é o mesmo que per- 
-, abunda nos textos que visam um leitor alargado, pouco exigente, habituado a uma literatura fácil (50). De facto, esta noção de que a metáfora é frequente, disseminada por todos os tipos de linguagem, de certa forma superficial, instrumento de floreado retórico pondera entre muitos estudiosos que dela se ocuparam ${ }^{28}$ :

E foi como se (este "como" não introduz metáforas, por ora, que as reservo para mais tarde ${ }^{29}$, talvez dedicando-lhes meio capítulo ou um inteiro, para conferir um toque de literaridade petite-bourgeoise, muito vendável, a este texto ...)

Dessas metáforas protocolares, a memória arquivou bons exemplos (103):

... contra um carro que lá vinha rápido, não apenas como o pensamento, à maneira do de Cardoso Pires ...

Com o tempo, a metáfora vai-se tornando um pouco saturante, no seu convencionalismo formal (88):

Indiferente às recriminaçôes (esparsa e passageira numa chuva de penugens negras, e vá de metáfora .......

Por fim, acaba susceptível a diferentes paladares, ora mais urbana e subtil, logo mais rústica e pedestre (141):

Jogar em vários tabuleiros! É esta subtil alegoria, decerto inventada por quem não percebe nada de exercícios escaquísticos (...) que me

cepcionar as semelhanças" (1459ª 6-8). Sobre a metáfora, vide ainda Lausberg, H. (1963), Elementos de retórica literária. Trad. portuguesa, Lisboa, Gulbenkian: 161-162.

28 Vide Gomes da Torre, M. (1992), “Acerca da tradução da metáfora”. Linguas e Literaturas 9: 212. No desmembramento e catalogaçáo que se tem pretendido fazer da metáfora, em tipos representativos das suas várias expressóes, é interessante registar a sugestáo de Netwark, apud Gomes da Torre 1992: 213: "Distingo seis tipos de metáfora: morta, cliché, tradicional, adaptada e original”. A aproximaçáo com o cliché é importante no contexto que temos vindo a desenvolver.

29 É curiosa esta táctica do que chamaríamos a 'promessa falhada' do autor; muito comum desde tempos muito recuados nas narrativas de grandes dimensóes - caso de Heródoto, por exemplo -, sinal de distracção do autor ou de incompletude da obra, este tipo de compromisso pode tornar-se recurso literário de efeito sugestivo. 
ocorre agora, por me parecer menos rural que "comer a dois carrilhos", ou outra, semelhante ...

Da figura de estilo pontual, M. Carvalho expande-se para uma convenção mais ampla: aquela que se veio a designar, já em pleno Renascimento, por "utopia", mas que a Antiguidade, sem lhe dar nome, reproduzia já à saciedade. Estamos, assim, diante de um tópico de raízes fundas e convençōes fortes (152):

E Joel traçou a traços gerais, com gestos amplos, os recortes de uma sociedade outra, que eu não sei bem onde fica, mas deve ser à esquina do reino da Barataria com o Kingdom of Nowhere, frente aos domínios da Cocanha, com a ilha da Utopia à vista, rebrilhante dos ouricalcos da Atlântida. ${ }^{30}$

Foi sobretudo a comédia grega antiga o território que mais fôlego deu à célebre fantasia do 'sem lugar'. Capaz de subir às alturas do céu, de baixar ás sombras do Hades, à procura de um bem perdido ou de uma réstia de paz a opor à crise social, a comédia insistiu no modelo com estratégias que, em traços largos, M. Carvalho aqui ressuscita. Utopia é sempre uma alteridade, a busca de um outro lugar diferente daquele que se conhece, por vantagem ou defeito. Lugar esse de pura fantasia, o sem lugar, geograficamente identificado por topónimos que a imaginação ou a tradição mítica inspiram (Barataria, Cocanha, Utopia, Atlântida). Miragens de facilidade ou fortuna (Barataria, rebrilhante dos ouricalcos) ornamentam a utopia, construída em fronteiras difusas, mesmo assim aludidas com abundância de pormenores (uma esquina, frente, uma ilha, à vista) ${ }^{31}$. Nesse horizonte, Joel Strosse procu-

30 Um bom exemplo de estratégia semelhante à aqui usada pode ser a descrição que Caronte, o barqueiro do inferno, faz do itinerário infernal, em Aristófanes, Rãs 185-187: "Quem quer ir para o Eterno Repouso dos males e dos negócios? Quem quer ir para a planície do Esquecimento, para a Terra Onde o Diabo Perdeu a Cartola, para os Cerbérios, para o Raio que o Parta, ou para o Ténaro?” Aqui se misturam topónimos relacionados com a geografia mítica do Hades (o Letes, rio do Esquecimento, ou o Ténaro, um promontório da Lacónia, que marcava a entrada do inferno), gracejos sobre realidades tradicionais no mundo dos mortos (caso do cão Cérbero, o guardião da entrada do palácio de Plutão, que passa a dar nome a um clã ou tribo), e finalmente sobre expressôes que designam, na linguagem comum do grego antigo, fórmulas de não lugar ou maldição (o lugar onde se tosquia o burro, ou ir aos corvos).

31 Sobre a tradição antiga da utopia e algumas das suas mais famosas realizaçóes, vide Melero Bellido, A. (2001), "La utopia cómica o los límites de la democracia", Cuadernos de 
ra, como é de regra, um refúgio ideal, "uma nova sociedade em que ninguém tivesse necessidade de recorrer a paraísos artificiais, em ... em que ... em que", suspensão que abre espaço ao infinito da imaginação humana.

Em contraste com o colorido das figuras de estilo ou o convencional dos eternos episódios da ficção, pode considerar-se o despojamento inábil e elementar do uso da mais neutra das palavras, "coisa" (33):

Reparem bem: coisas - mais tarde, se tiver tempo, falarei sobre a legitimidade da utilizaçáo do substantivo coisa em literatura e jornalismo. Não foi o Bernardim a escrever: "ua cousa cuidava eu / causa de outras muitas cousas ...?".

E mesmo esta palavra, em toda a sua vulgaridade quase agressiva, representa um material informe; moldado por um verdadeiro artista das letras, ou por um descontraído jornalista, o resultado que se produz será indiscutivelmente diverso.

Sem ser decorativo, mas de enorme importância para o tom geral do texto, principalmente para a relação entre o narrador e as personagens, é o uso da pessoa verbal em português, ponto sensível em que a língua condiciona a convivência humana e se converte em elemento sociológico essencial (20):

O licenciado Joel Strosse dificilmente suportava que, fora de uma leve intimidade, um desconhecido o tratasse por você. Você é estrebaria, sete fardos por dia ...

A partir desta sensibilidade do seu protagonista, M. Carvalho enceta a discussão sobre a questão delicada das fórmulas de tratamento na Língua Portuguesa, levada ao exagero de responsável por "duelos e mortes". Como questão a que se quer dar antiguidade na experiência nacional, um recuo ao séc. XIX traz à memória um duelo ocorrido em pleno Chiado, o coração da Lisboa do tempo, causado pela sobranceria fidalga de alguém que brindou outro com um "Vossa Mercê". Transpor o diálogo para época recuada traz ao texto o tom do antigo e revela como, também neste particular, a língua evoluiu impiedosamente. Mas o que permanece é o peso da convenção social e o desentendimento do interlocutor, que se sente visado

Literatura Griega y Latina 3: 7-25; Silva, M. F. (2007), "A porta na comédia de Aristófanes: uma entrada para a utopia", in Ensaios sobre Aristófanes. Lisboa, Cotovia: 257-274; Silva, M. F. (2009), Utopias e distopias. Coimbra, Imprensa da Universidade. 
pela displicência da fórmula. Strosse, agora em pleno séc. xx, tempo que já não é de duelos, não tinha sequer fibra para se arriscar em golpes violentos; mas mais do que condiçóes para tais rasgos de ameaça,

não se encontrava bastantemente apetrechado de independência material e social para enfrentar o seu chefe directo.(20)

Estatuto económico e social, hierarquia, eis o que condiciona sem apelo as subtis nuances do modo de tratamento e incomoda o visado. Do seu interlocutor, o desconhecimento da fórmula correcta revela ignorância, ou pior, uma insolência primária e injustificada ("que ele não se encontrava ao corrente da pragmática do Português. Ou, dito por outras palavras, (...) que o outro era um casca-grossa um tanto ajavardado, simbólico de ruins tempos").

Mais hábil do que o "casca-grossa" director de serviço, a Eduarda Galvão, no assédio que fez do Jorge Matos, seu antigo professor de Francês, de quem deseja auxílio na traduçáo e aconchego num abraço, domina por completo as subtilezas do tratamento. Em escala ascendente, cumpre todas as etapas da abordagem (80):

Atentos como estais, já reparastes que Eduarda subrepticiamente já tinha abandonado no trato o "senhor doutor", passando a "doutor", abrindo a progressão para o "você", ou mesmo "o Jorge" e, sabe-se lá, se "tu". A isto se chama em linguagem popular, esperta para as estratégias, "lançar a escada".

Repetições, redundâncias, figuras de estilo, fórmulas de tratamento constituem todo um património, mais ou menos convencional, que se oferece ao potencial criativo, e crítico, do autor.

\section{A escrita teatral}

À meditação sobre a escrita do romance, M. Carvalho sobrepóe, por intermédio do seu Jorge Matos, professor do ensino secundário, sabedor em francês, "o autor secreto de um montáo de peças de teatro inéditas" (45), uma abordagem da escrita teatral. Não se trata apenas de sublinhar contrastes de género, implícitos neste jogo de texto e sub-texto; trata-se também de considerar o destino de dois géneros a que o universo cultu- 
ral português conferiu distinto aplauso, popular o romance, tantas vezes simplesmente inédito o teatro. É assim que a produção teatral se esgota em sólidas pilhas de papel sobre anónimos sofás, "três ou quatro palmos de verticalidade discutível estratificando catorze peças de teatro" (47).

O estranho divórcio entre a escrita e a cena tem na sua origem - ocorrência dificilmente explicável - o pouco apelo ou tradição de que o teatro goza entre nós. Como tantos outros autores dramáticos, Jorge Matos não era espectador do mesmo (48):

Não por insensibilidade, mas por um motivo absolutamente fútil e irrisório: achava as salas muito desconfortáveis e detestava as peças em que os actores se metiam com o público e não deixavam um sujeito estar sossegado a fruir o seu serão.

As razões são, de facto, "fúteis e irrisórias": a primeira, o desconforto das salas, que é também a inadequação ao espectáculo, a distância, a frieza, que o poder da cena não logra romper. As tentativas de aproximação que os actores ensaiam num esforço para, quebrada a ilusão cénica, envolverem o público - tradiçáo que mais uma vez ascende a pelo menos vinte e cinco séculos de produção teatral, com origem na antiga Grécia, extensão já, ela mesma, de velhas práticas populares - fracassam também; num outro momento e em diferente contexto sabem a artifício, a profissionalismo, não são genuínas, criando reservas, em vez de adesão, no espectador (48):

A repulsa tornou-se ferozmente enfática quando, certa noite, uma personagem saiu do estrado e lhe afagou a barba, enquanto ia declamando solenidades.

É gritante o desajuste entre o que se torna num gesto de intimidade gratuito se concomitante com palavras solenes, inacessíveis, distantes (num risco semelhante ao que o teatro grego correu, ao misturar efeitos trágicos com outros cómicos). Na sua natureza paradoxal, esta parece a combinação ocasional e impensada de tradiçóes conflituosas, a grandiosidade ficcional da cena e a proximidade popular com o auditório. Há, para esse conflito desagradável, que alertar os técnicos (48):

E esta nota fica como motivo de reflexão para encenadores e actores dados ao improviso, e às gestualidades expansionistas, os quais devem 
encarar com muita reserva esta tentaçáo de incomodar quem se disponibiliza nas plateias e tem direito à paz de alma, para não dizer ao conforto.

Não fica sem remoque, na recomendação, o espectador, do outro lado da "parede de vidro" que o separa da cena. Ao uso despropositado da interacção, ele responde com a passividade, refugiado numa frieza e num conforto inertes, o que o torna o espectador indesejável, incapaz de uma verdadeira apate ${ }^{32}$. Nessa falta de interpenetraçáo reside o fracasso do nosso teatro, que de 'observação' - presente na etimologia da palavra 'teatro', como sua marca genética - o reduz a um mutilador objecto de leitura. Epicentro de todo o processo, como espectador em fuga, leitor devoto e criador incansável de peças de teatro, Jorge Matos acumulava os traços essenciais do retrato (48):

Lia as peças, sofria-as, decorava monólogos, sonhava com espectáculos cívicos em que comungassem o mistério, o logos e a polis.

Ou seja, sonhava com um regresso às origens, em que o teatro era de facto um fenómeno aglutinador, de intervenção social, mobilizador dos cidadãos em torno de uma cultura, com uma missão didáctica a cumprir; numa palavra, com o verdadeiro theatron da polis grega de que o espectador solitário, despegado da cena, enfastiado pela mediocridade da proposta se tornou a completa negação.

Mas se crítico e avesso, como espectador, à opçáo decadente do moderno teatro português, o Jorge Matos não soube, como dramaturgo, livrar-se da onda avassaladora que fez dele mais um autor condenado ao pó das prateleiras, pertença do "quarto e do sofá". Os defeitos que o deixavam insensível como espectador contaminaram o seu próprio ensaio de composição. O diagnóstico do fracasso parece fácil de obter: perfeccionismo exagerado, com a consequente falta de autenticidade, dimensão excessiva, falta de operacionalidade cénica, eis o que o padrão corrente denuncia (49):

32 Apate, 'engano ou ilusão', era a palavra que a antiga crítica literária grega usou para a capacidade que uma peça tem de atingir e de influenciar o público. Usada por Górgias no Encómio de Helena 8 e no Fr. B 23 (Plutarco, Moralia 348c), é vulgar em Platão, mas estranhamente ausente da Poética. Contudo um conceito próximo parece aflorar em 1460a 13, $1461 b 11$. 
Aquelas peças que se iam acumulando, algumas bem volumosas, quais delas escritas alucinadamente em noite de insónia, quais delas ponderadas e acrescentadas e alteradas penosamente no decorrer dos anos, estavam ali ...

E pareciam incapazes de se arrancar da inércia e do anonimato, projecção da própria impotência do seu autor. Mas qual a razão de tamanha inoperância? Porquê uma desistência tâo precoce e conformada, que sempre lhes valeu o medo de subirem à cena, afinal o seu primeiro objectivo? "Timidez, medo do inêxito?" A verdade é que, na sua resignação, espelhavam o fosso que separa o gelo da teoria do calor envolvente da prática (49):

Enquanto as peças de teatro dormitassem naquele sofá, era a renovaçáo da dramaturgia portuguesa que estava em potência; uma vez que fossem devassadas, interpretadas, representadas e abominadas, representariam mais uma prova da nossa inépcia para a dramaturgia.

Em resumo, está dentro do espírito dramatúrgico português, no seu sentido mais genérico, a propensão para o demasiado intelectual, em prejuízo do verdadeiramente teatral; numa palavra, potenciais autores de peças para a prateleira esquecida das bibliotecas ou táo somente para o sofá doméstico de qualquer cidadão.

Mas olhemos com mais atenção - valendo-nos da indiscrição que o romance nos faculta desvendando-nos os segredos do Jorge Matos - para alguns dos traços concretos dessa produção de sabor bem português. Primeiro, os temas preferidos quais são? Os históricos compõem um sector bem conhecido. Das catorze que se empilhavam no sofá do Jorge Matos, duas eram históricas (47). E por históricas se pode entender como referentes a um passado distante. Nelas está implicada a necessidade de mergulhar numa outra realidade, de pesquisar detalhes do quotidiano oculto pelo tempo, de transplantar o destinatário, por força de vários estímulos, para o contexto de séculos que não o seu (87):

Ele sabia o bastante sobre ceitis, porque tivera de estudar numismática medieval para uma peça de teatro histórica sobre a questáo da Beltraneja e implicaçóes sociopolíticas correlativas.

Mas histórica é também a abordagem de acontecimentos mais próximos, que saltam das páginas dos jornais para a virtualidade da ficção (49): 
Preparava-se para (...) lançar o terceiro acto de uma teatrada sobre um médico bósnio que o seu próprio filho (de mãe sérvia) sequestra para tratar de um companheiro ferido, tencionando começar com "lembras-te, filho de quando os castanheiros estavam em flor e tu vinhas correndo, de calçóes, gritando ...” Tenso, tenso e comovente ...

À sugestáo discreta de um conflito conhecido da modernidade europeia mistura-se, em flagrante contraste, a reduçáo estreita de tensóes familiares em tempo de guerra. Nada a que uma humanização da tragédia antiga não nos tivesse habituado, já no séc. v a. C., sobretudo pela mão de Eurípides com os seus oikeia pragmata, 'assuntos domésticos' (Aristófanes, Rãs 959). Mas Jorge Matos não é, claro está, um Eurípides! O triângulo familiar, prometedor de um choque de geraçôes, de culturas ou de sentimentos desfecha num convencionalismo frustrante, expresso por memórias artificiais de um passado onde a pujança da natureza esbarra com os vulgares calçóes de um qualquer garoto em fuga. Tudo muito previsível, batido, mas sobretudo vazio de tensão e de talento ...

É ainda do quotidiano social, já não dos grandes conflitos históricos, mas das crises que delapidam a realidade colectiva, que surgem outras fontes de inspiração; talvez porque mal dimensionadas ou restritas na sua formulação, elas póem à prova a fraca imaginação de espíritos sem talento, incapazes de arrancar de uma lista de tópicos uma intriga profunda e coesa (112):

Surpreendido em casa, indefeso, a matraquear a segunda página, ainda de rubricas, de uma outra peça, versando sobre as condiçôes sociais da toxicodependência, Jorge lá abriu a porta ...

Por fim, num afunilar redutor e decadente da perspectiva criadora, vem o aproveitamento de desaguisados pessoais, de rixas domésticas, de divergências conjugais vividas ao telefone, a simples e mera convenção de uma retórica que dá pelo nome de "gritaria ex-conjugal" (197), como fonte de inspiração dramatúrgica:

E no meio de faíscas agressivas, queimadoras, que ressaltavam das recordaçóes, ia-se insinuando em Jorge a tentação de aproveitar o diálogo para a sua última peça de teatro, tal a complexidade da humanal natureza pensante ... 
Do tema se parte para um segundo requisito, o de encontrar para ele o agente mais apropriado, a personagem mais conveniente. E aí a dificuldade recrudesce, o sofrimento refina, num esforço do autor para conferir ao seu actor gestos e palavras adequados. Facilmente a escassez de talento se refugia no artificioso e teatral (53):

Jorge por essa altura sofria, concentrado sobre uma personagem que se interpunha entre dois grupos de guerrilheiros, bradando: "Parem, que razão têm para me matar a mim?", para apontar, depois, o dedo acusador à esquerda e à direita altas: "Que razão têm para se matar assim?” As palavras pareceram-lhe redundantes.

Principalmente os momentos chave, os que abrem ou fecham a acçáo e querem deixar lastro no espectador, são os que exorbitam em convencionalismos e tendem a um espalhafato vazio (74-75):

Mal acabara de atirar os restos de comida para o lixo e imaginava já a última frase da peça, com o pai bósnio a soluçar junto à campa do filho baleado, exclamando: "Nunca mais!" para fazer cair o pano, quando a campainha da porta retiniu ...

Com a instigação de um gesto rotineiro, tendo por Castália um balde do lixo, Jorge abstrai-se no que lhe parece um fim condigno, romântico, patético, expresso em palavras sem sentido, para uma peça também ela fracassada e tremendamente flácida. A que associou outras hipóteses, em dimensóes de mobilizaçáo diversas, ora focadas numa cena divorciada do seu público, logo num público separado da cena, ou, por fim, num modelo globalizante (75):

Talvez fosse melhor a sua personagem rematar com um grito: "O culpado sou eu!" Ou apontando para a plateia: "Os culpados sois vós"” $\mathrm{Ou}$, mesmo, num grande gesto circular: "Os culpados somos todos nós!”

Outras componentes, se não tão extremas, são mesmo assim cruciais. Da velha tradição provêm os longos monólogos, prova de fogo para qualquer actor, desafio à atenção do público - sobretudo o mais susceptível ao visual e avesso ao auditivo -, mas instrumento de expressão de sentimentalidades ou arma de reflexấo dos conceitos sustentadores da intriga, 
como o discurso político em tempo de guerra. Se mal sucedidos, são fonte garantida de um enorme aborrecimento (67):

E logo na manhã seguinte, quando ele pensava inserir na peça sobre a Croácia um atribulado monólogo de doze minutos, muito estruturado, proclamando a renúncia aos canhóes!...

Ou então as metáforas, um instrumento de linguagem mais difuso, remissão disseminada no texto, a apontar para um ponto de referência, no caso obediente ao próprio título (172):

... preferiu recorrer à metáfora do alpinista, que aliás era toda a simbólica da sua última peça de teatro, que se chamava, precisamente, $\mathrm{Na}$ Montanha.

Atenta aos modelos convencionais, conhecedora dos recursos consagrados, a medíocre dramaturgia portuguesa é o resultado de um transplante rotineiro, impessoal, esgotado de efeitos, incapaz de insuflar ânimo novo em fibras ressequidas pelo tempo e pelo uso.

\section{A escrita jornalística}

A experiência, como jornalista, da Eduarda Galvão é o ponto de partida para a caricatura bem sucedida de alguns aspectos da produçáo periodística, de jornais e revistas. Primeiro, os jornais comparecem em Era bom como expressão de uma sociedade de imprensa livre, os tais pasquins "desinibidos", que nem por isso souberam consolidar uma verdadeira informação, séria, consistente, fundamentada. Refugiam-se, isso sim, no pequeno escândalo, na inesgotável corrupção, nos meandros imperscrutáveis da justiça que, como é do domínio público, a nada conduzem (13). Depois de envolvidos em intermináveis e inúteis discussôes produzidas pela grande corrupção, remetem o assunto ao silêncio, já gulosos de novo escândalo promissor de vendas de sucesso. O que num momento alimentou pilhas de papel e rios de tinta remeteu-se, com o tempo, a um total olvido, pontualmente quebrado com "algum remoque raivoso numa coluna de jornal" (15). De registar é a popularidade fácil que adere ao chamamento de títulos vazios ou de fórmulas feitas nas letras gordas ou em grandes frases de fecho, como se neles submergisse a nulidade do conteúdo (18-19): 
... e ter escrito para um jornal popular um artigo célebre intitulado "A mão invisível actua com pés de lã”, finalizado com um bramido muito festejado pela originalidade: "Laissez faire! Laissez passer!"

Mais promissora ainda de paródia é a revista, que M. Carvalho hierarquiza, por países de origem e concomitantes preferências culturais, por públicos alvo, no que parecem os condicionalismos mais restritivos. Afinal não é a imprensa a educar a sociedade, mas esta a impor-lhe exigências, preferências controladas por uma autoridade última: audiências e proventos de vendas.

A imprensa francesa identifica-se pela revista politica, o artigo de fundo, a teoria revolucionária que defende (42):

Joel Strosse tinha agarrado numa revista francesa, Ça ira!, e procurava concentrar-se num artigo intitulado "La gauche post-moderne, une déconstruction en marche?"

Registemos, em primeiro lugar, a determinação do título encontrado para a revista, a apostar num paradigma de apelo revolucionário, Ça ira!, fácil, directo, dirigido a um público determinado. Intenção que o título atribuído ao artigo - La gauche post-moderne, une déconstruction en marche? - não apoia. $\mathrm{O}$ que o título geral tem de informativo e estimulante no seu tom exclamativo, tem o do artigo de ambíguo, de polémico, de possivelmente prolixo, avesso a qualquer objectividade ${ }^{33}$. A um leitor comum, um qualquer Joel Strosse, a sensaboria repisada do assunto, dos conceitos, da linguagem, não lhe permite ultrapassar o primeiro parágrafo, "com aquela chatíssima revista francesa na mão, sem andar nem desandar do sempre mesmo prolixo artigo" (43, 68). Independentemente do número, a Ça ira! prossegue invariavelmente na mesma opção, identificadora de uma imagem comercial (150):

Instalado no escritório, munido de tesoura, ele recortou um artigo da Ça ira!, cujo tema era "adaptação da esquerda consequente às vicissitudes do Mundo moderno".

Incentivada por tempos de revolução e mudança, a imprensa portuguesa, à sua medida, deu sinais de interesse equivalente. Aos acontecimentos

33 Sobre o efeito da linguagem jornalística na sociedade contemporânea - "o cliché é o grande veículo de transporte em comum do pensamento moderno, da comunicação medíocre" - vide Jourdan 1996: 51-52. 
próximos, não foi estranha a tendência para a imitação do que, fora do país, se ia produzindo. Em pasquins anónimos, de província, deu-se largas a um ataque político, de feição extremista e polémica, num estilo adiposo de imagens e metáforas (164), protegido pela couraça de um pseudónimo:

Esse gajo, que depois do 25 de Abril andou a escrever artigos reaccionaríssimos para o boletim paroquial de Fafe, em que chamava à revolução "o touro vermelho" e designava o Álvaro Cunhal por "o demónio branco das estepes?" Até tinha uma frase que ficou célebre: "esses senhores da esquerdaria precisam mas é dumas nalgadas nas abas da consciência" ...

O gajo usava um pseudónimo, O Vingador, ou coisa assim (cf. 176).

Referência da mesma imprensa francesa é o Paris Match (63), numa perspectiva que já não é a da polémica política mas a de uma informaçáo de grande espectro, a pender para o imediato e sensacional, atirado a uma jornalista inicianda como modelo a seguir. Na pele do leitor comum, a Eduarda Galvão desconhece o texto, para se deixar prender pelo acessório, "os bonecos" e os atractivos superficiais da grafia. Um scaphandreur a legendar uma fotografia, para que, no português, não encontrou versão - "escafandrista", "escafundista", "escrafandista" -, seduziu-a pelo exótico do $p h$. E lembrou ao autor a perda, etimológica e exótica, das aspiradas no Português:

Roubaram-nos o phósphoro, a pharmácia, o diáphano, o aphorismo ... Bem assim, o y e o th. Bonito que jazia o myrtho, dolente, ao pé de restos de colunas, em florestas sombrias, cheias de húmus e cogumelos, por onde esvoaçavam divindades, nada aparelhado com o mirto que se vende nas praças, sob gritarias, ao lado de rabanetes e raminhos de salsa ...

Milagre de uma simples aspiraçáo ou $y$ grego, capaz de transformar um mundo remoto, misterioso, divino até, na mais vulgar e rasteira contemporaneidade. Sem o saber, Eduarda 'comprou' esse fascínio de que a Paris Match continua a fazer um trunfo.

Por seu lado, a imprensa espanhola cristalizou nas revistas de VIPs "revistas pernósticas dos vizinhos ibéricos" -, focando-se na imagem de gente distinta, de nome sonante, sempre ocupada em lustrosas e inúteis reuniōes sociais (29): 
... folheando uma propalada revista espanhola, escrita em castelhano, que trata de condes, financeiros, toureiros e mafiosos e de cujo nome não quero recordar-me.

Atenção particular merece a "imprensa feminina", a atrair o empenho calculista dos editores, certos de uma venda segura. Estáo dela arredados os artigos de fundo, com missão social ou educativa, em favor de matérias superficiais, ligeiras, animadas de fotos. A Elle é, do modelo, um paradigma. Em atitude de relaxe e de inércia, em tempo de lazer, Cremilde não "lê", "folheia" a Elle, seduzida por uma informação de discutível utilidade ou pertinência (43-44), veiculada não por uma autoridade, mas por um "alguém" anónimo:

Vem aqui que as varizes não têm cura. A operaçáo pode aliviar um bocado, mas cura é que não há. É um médico que diz. Traz a fotografia e tudo.

Foi nestes sacrossantos modelos que a Eduarda encontrou inspiração para as versóes nacionais que ela mesma, num crescendo profissional, replicou. E M. Carvalho elabora o retrato irónico de uma jornalista criada nas redacçóes, nos modelos importados, penosamente destituída da mais elementar cultura e insensível à estética da língua. A sua primeira experiência na profissão foi na "Modelar (hábil contracção de Moda+Ode+Lar)", título por demais expressivo do fôlego temático e do público destinatário do projecto. Com o desmembramento de uma legenda artificiosa recorda-se o primeiro traço identificativo de uma revista, o título, e o potencial que lhe é próprio, de, em poucas palavras, estabelecer uma proposta, um estilo, um público, um mercado. Inspirado por temas da televisão generalista, o primeiro artigo que a Eduarda se propôs produzir foi sobre o naufrágio do Titanic, claramente arredado dos tópicos da Modelar, moda, ode, lar. Para jovens em busca de afirmação, o tema proposto parece reunir todas as credenciais mais promissoras (55):

É apaixonante, apelativo, dramático, há sobreviventes, implicaçôes religiosas, e, sobretudo, imenso material publicado que se pode plagiar à vontade.

Para além do sensacionalismo, sem compromissos ou riscos sociais porque remissivo para matéria antiga, o naufrágio do Titanic beneficiava ainda da falta de contra prova; e mais do que isso, era matéria requentada, onde 
toda a escassez de talento encontrava refúgio seguro. Ligeireza, ignorância e falta de imaginação, eis o que parece caracterizar o 'tipo' do profissional jornalístico. Não admira portanto as reservas da edição. Mas não se pense que pelas melhores razóes. Afinal o que levantou objecçôes foram "umas complicaçōes de ortografia", e principalmente o desajuste óbvio do assunto em revista feminina, como se o seu valor efectivo fosse critério arredado. A censura não deixava de ter algum fundamento, tidas em conta a frase de abertura, tâo pouco de moda, ode ou lar, tâo pouco de revistas femininas e finalmente tão própria de coisa nenhuma, simplesmente "redundante, burocrática, primária" (56): "Em primeiro lugar temos que considerar que ..." . Gerou-se a confusão na Modelar, entre a aquisiçáo novata, a experiência de trinta anos de jornalismo na censora - estudiosa atenta dos modelos consagrados no jornalismo para a mulher, a Crónica Feminina e a Maria -, e o chefe - e árbitro da contenda -, um antigo negociante de frutas que do assunto nada sabia. Mesmo assim, com um talento inato para a arbitragem de questóes difíceis, o chefe produziu a solução de compromisso: "As Mulheres e o Titanic" ou "O Titanic e as Mulheres" como título salvador, mantidos cortes e correcçóes. Solução salomónica para a boa ordem da editora, ainda que conflituosa para a pertinência do artigo: Titanic e as Mulheres num desencontro flagrante, num vazio irremediável, salvo apenas pela promessa de algum patético. Recordada do sucesso com a Modelar, uma futura mudança para a Reflex viria a abrir nova oportunidade ao naufrágio do Titanic. No que parece já uma sofisticação do usado material, a uma jornalista com algum traquejo a exigência pede outro contorno (171):

Tinha a propor-lhe um trabalho sobre o Titanic, nos aspectos sociais e culturais, bem entendido, trajos, ementas, luxos, etc. Já pensara num título: "O último baile a bordo ..."

Muito promissor agora, o eterno assunto moldava-se melhor à medida do mesmo público. Sem que 'mulheres' tivesse de figurar no título, como um destinatário confesso, a mençáo do baile, associada a trajos, ementas e luxos, fazia com que um naufrágio, assunto mais próprio para "uma revista de musculação" (56), se convertesse em festa de alta sociedade. E aí sim, a imaginação feminina encontraria condimentos da sua preferência.

À mesma galeria editorial da Modelar pertenciam outras pérolas, As Delícias de Satã, O Construtor Civil, Horoscopias, Poupar e Ganhar, Gatinhas em Brasa, títulos unidos pela ambiçáo modesta, pela inutilidade vulgar, mas divergentes no público alvo. $\mathrm{O}$ tom é agora outro, sexo, di- 
nheiro, negócios, a procurarem sensibilidades masculinas. Para satisfazer as necessidades editoriais da Modelar, à equipa de redactoras acresciam outras especialidades, "a colega que redigia os horóscopos e o correio sentimental" e o inevitável fotógrafo (56), para satisfazer o aparato visual que este tipo de literatura jornalística tende a incluir.

Hábil e dotada para a carreira que escolhera, vinda da boutique de um centro comercial com passagem pela caixa de um supermercado (54), Eduarda fez, na Modelar, uma progressão meteórica, que lhe valeu as coroas desejadas. $\mathrm{Na}$ hierarquia da imprensa jornalística, viu o seu nome registado no Expresso, escassos dois meses de tirocínio passados, ainda que com modéstia de espaço (57): "O seu nome veio citado no Expresso, numa pequena local intitulada "Como é isto possivel, meu Deus!". Sobre um título que afinal transparecia a ambiguidade de uma censura, reluzia o brilho de uma qualquer mençáo no Expresso. Logo na sua própria revista os sucessos e as promoçóes se somaram, com ganhos de espaço e diversidade de temas (57); "passou a fazer um novo correio sentimental, O cordão das Emoçóes, e a assinar uma rubrica, Vá descobrindo o seu corpo, ao mesmo tempo que os seus artigos de fundo se coadunavam também melhor com a escola a que a Modelar obedecia, ditada pelos triunfos irrecusáveis da Maria, "que são guia e farol da imprensa". A autora do naufrágio do Titanic, credora de uma oportunidade devida a um talento em potência, pisava terreno firme, consciente das regras precisas do seu contexto profissional.

Ao triângulo formado pelo criador, obra criada, destinatário, falta ainda a palavra ao último, e não despiciendo elemento; se falho de adesão, está posto em causa o equilíbrio gerador de sucesso. A voz do leitor chegou, no caso da Eduarda Galvão, por mão de uma leitora, cuja credencial suprema era a fidelidade à rubrica Cordão das Emoçóes (58). De sua autoria, enviou à Modelar um livro de sonetos, com o toque consentâneo à rubrica de que era leitora assídua, “'Olhando-te, meu amor, um acaso se anuncia”, e por aí fora com rima em ia”. Foi a oportunidade inesperada de a Eduarda se assumir como 'crítica literária', propriamente a coroação de uma carreira. Sobre a oferta redigiu uma nota de censura, pelo retrógrado do modelo poético, e remeteu a autora censurada para a leitura de "Alberto Hélder", o mais longe que podia ir a sua cultura de ouvido. Colhida na Universidade, não da vida, mas da noite - a dos bares e boîtes -, a sua cultura impôs-se a um público de ignorantes entusiastas, seduzidos pela cor gritante de um vocabulário intelectual, onde náo faltavam "blasé, interface, intertextualidade, frontispício, new age, paralaxe, 
pórtico" (58). Mas o certo é que, em homenagem à sua ousadia, se tornou objecto de ofertas constantes de outros títulos, e se pôde dar ao luxo de olhar por cima do ombro os colegas de ofício.

Ganho o sucesso e credenciais de experiência, a transferência para outra revista, a Reflex, uma inovação periodística "que já ia quase no número zero" (60), abriu-lhe as portas à intervenção numa outra rubrica, bem à medida da nova Eduarda, aquela por que era responsável o departamento de Sociedade \& Cultura. Foi diante de uma placa promissora - "Reflex, o Mundo num Relance" -, que nova porta se franqueou à sua ambição. Como tantas outras revistas da Modernidade, a Reflex iniciou-se com pompa e circunstância, "em cerimónia lustrosa e frequentadíssima” (63), que teve por cenário o Palácio de Queluz. Houve banda de música, fardas medievais, discursos, do accionista canadiano e do director indigitado português. $\mathrm{Na}$ linguagem estropiada do primeiro e firme do segundo, foi lançado um voto de sucesso e a profecia da inovação, a promessa de que se tratava de "uma pedrada no charco da informação em Portugal". Em redor, levantou-se o coro reprovador da concorrência, que funcionou sobretudo de publicidade bem vinda. Cumprido o lançamento, veio o plano, accionista e director unânimes na política redactorial a seguir (64):

E resolveram utilizar uma fórmula expedita, impregnada de ecletismo, na composiçáo da redacção: de um lado, uns veteranos empedernidos de andanças em jornais e em protestes cívicos, algo sabedores do prontuário ortográfico; do outro, uma caterva de moços, a que eles chamavam "a passarada", mais virados para as facilidades da vida moderna e da ortografia minimalista.

Diversidade de geraçóes, com a concomitante componente escolar e cultural diversa, sensibilidades distintas na escolha dos materiais e no estilo da redacção, garantiram variedade à informação e amplitude ao leitor visado. Bastou o número zero para testemunhar a pertinência da opção (64):

Ao lado do sisudo artigo de fundo, versando a premência da ética na vida política, aparecia a local brejeira muito "social" com especificações amaricadas e perfidiazinhas do género: "Ai, a Necas ia tão composta no baile dos Vanzeleres... Mas aquele cheiro de after-shave era de origem ou pegado?" 
Desta vez, não se trata de visar públicos femininos ou masculinos, mas um universo indiferenciado, onde a evolução do próprio modelo jornalístico fazia da Reflex um monumento ao anacronismo e à anarquia. Do texto político à crítica social mais brejeira e de mau tom, todos os gostos estavam contemplados, num português mais escorreito ou mais "minimalista".

$\mathrm{Na}$ corrida vertiginosa da inovação, também a Reflex, que vimos nascer com galas de novidade sobre a geração que a Modelar representava, se viu vencida por um outro marco de uma edição mais vanguardista. A queda chegou com a incapacidade de concorrer com a Uau!, uma revista nova vaga "que dedica, no máximo, três linhas a cada notícia, sete aos artigos temáticos e dez ao editorial" (212). Na anulação do interesse, pertinência ou simples configuração dos assuntos, o novo trunfo traduz-se em brevidade, o laconismo que uma geração aprendeu na linguagem dos mails ou das SMS. Com o fluir profissional da Eduarda Galvão, o leitor percorre também um processo evolutivo no critério de revista de grande divulgação. A tendência é para integrar, sob um mesmo título que se quer vistoso, uma produção mesclada, dirigida a um leitor indiferenciado, sem preocupaçóes de utilidade pública. A rendição às preferências do leitor medíocre converteu-se na principal motivação.

Antes de deixarmos a linguagem jornalística, demos ainda espaço a um breve comentário ao que nela são, na sua índole própria, matérias de excelência: a entrevista e a reportagem.

Para a entrevista, o primeiro grande desafio na passagem da Eduarda pelo Departamento Sociedade \& Cultura da Reflex, valeu o modelo celebrado do Paris Match (64-67). E desta vez a inspiraçáo não se ficou pela leitura, foi mais longe; utilizou a réplica, repetiu o padrão, "plagiou" o motivo. A aventura do escafandrista parisiense, o francês Bertrand l’Église, que deu notícia em Paris, foi repetida em Lisboa, em exclusivo para a Reflex. A origem da personagem era modesta, simplesmente a de um funcionário despedido da Renault, imagem de incapacidade e frustração. Que o náo desanimou, antes o incentivou ao golpe popular, a rondar o expediente barato. De um tiro de catapulta que o lançou num voo sobre Paris, ou da aventura de risco numa jaula de leóes do Zoo de Vincennes, o nosso homem acabou escafandrista no Sena, como iniciação à prometida travessia "de todos os rios das principais cidades da Europa". Tanto bastou para o celebrizar no país e no estrangeiro e para atrair a imprensa. Assim se cria o eco fácil da popularidade e do sucesso. Eis o momento para a Reflex, aproveitando o mote, candidatar o Tejo a um segundo momento de celebridade. 
Fotógrafos e operadores de câmara prepararam-se para dar ao episódio o brilho jornalístico merecido. Não sem que o escafandrista, minimamente informado da realidade portuguesa, náo tivesse pensado associar, à imagem, a palavra, e ao seu gesto o lustro das letras. Foi aí que se lembrou de fazer "publicar um álbum com o título Sobolos rios ..., assim mesmo, em português antigo, que dava mais mistério" (65). Junto à Torre de Belém, o cenário escolhido, dava-se uma lição de jornalismo frustrado. $\mathrm{O}$ assunto do mergulho, já de si modesto - sob as penas do sensacionalismo -, fracassava, desde logo pelo pressuposto errado da dimensão do rio, avaliado pela medida do país. Faltava vencer outra barreira, a da língua, que separava o entrevistado da jornalista e do leitor. "Ignorância" seria o título, para todo um episódio de nonsense, mobilizador de um público desqualificado.

Como recurso salvador, a Eduarda, destacada para o efeito, valeu-se do antigo professor de Francês. E teve de reconhecer, perante ele, humildemente, que idiotices do género são tarefas a que se sujeita "a pardalada", os tais jornalistas em início de carreira (72). O resultado esteve ao nível do motivo, o engenho não foi além de um consabido "Aimez-vous rester au Portugal?", a que a resposta "Mais bien sûr je resterais là toute ma vie dès que ...", de tão esperada, não levantaria dificuldades de compreensão $(73,86$, 89). À exuberância de qualquer aventura, a linguagem da entrevista acode com a versão estafada das perguntas e respostas convencionais, transmitida pela tradição profissional, de onde o verdadeiro saber e criatividade estáo ausentes. E prosseguiria com tolices sobre o gosto da aventura que ninguém "dotado de mediano bom senso se daria ao trabalho de ler" (86).

Apesar da mediocridade, a nova jornalista triunfou, exactamente por corresponder às exigências gerais, da produçáo e do consumidor. Coberta de êxitos, a Eduarda foi incumbida de uma outra entrevista, desta vez com responsabilidade: a de questionar Agustina Bessa Luís, nessa altura muito em voga (118). Como preparação, a jornalista ficou-se pelas primeiras páginas da Sibila, lidas já no comboio. E foi com preconceitos infundados na mente - "esperava encontrar uma senhora de meia-idade, de cabelo platinado, num apartamento de duas assoalhadas, rodeada de gatos, com begónias no peitoril das janelas e versos manuscritos emoldurados" - e ideias ligeiras sobre a produção da entrevista que afoitamente se lançou na aventura. A pergunta com que a abordou era de catálogo: "depois de A Sibila, tenciona regressar à escrita? E, se sim, porquê?" (144). E por aqui se ficou, recebendo da escritora uma informação paciente dos rudimentos da sua bibliografia. Foi de novo com a ajuda de Jorge, que do nada surgiu a entrevista escrita, sem a intervenção da interessada, num modelo falsificado 
sobre outras entrevistas com Agustina, testemunhadas por uma colecção de recortes cuidadosamente guardados (170-171). Só mesmo à altura da entrevista feita por um jovem jornalista a um outro escritor; num rasgo verdadeiramente trimalquiónico, em hora de má disposição, o entrevistado debitou, à ignorância do outro, uma mistura anacrónica de episódios e agentes da História (145). Informaçôes essas passadas escrupulosamente a escrito pelo jornalista, compuseram um artigo que fez desabar a Reflex, e a carreira de uma jovem promessa! Risco esse a que a Eduarda se não sujeitava, escudando-se na generosidade de um velho professor arrancado das memórias da juventude. A caricatura do modelo 'entrevista' observa as diversas etapas conducentes ao fracasso: a escolha leviana do motivo, a escassez de formação do jornalista, a pouca exigência do público, sobreviventes à luz de uma preferência pelo sensacionalismo gratuito.

À entrevista acrescente-se a reportagem. Em comum, ambas partilham o mesmo objectivo de facilidade, de exterior sonoro, e um critério ligeiro de selecção explicável por um paradigma canónico (99):

Se um cão morder um bispo, não há notícia, mas se for o bispo a morder o cão, já há.

No momento em que, o que náo passava de um lema teórico, se tornou realidade, o frenesi que se apoderou da redacção ilustrou os interesses vazios da notícia. Multiplicaram-se os depoimentos (100), um sargento da GNR de serviço debitou a fraseologia convencional na circunstância (109): "O caso ("a ocorrência") era da competência dos tribunais, mas não destituída de gravidade” e o dono do cão sustentou que “"ele há coisas nunca vistas" .... $\mathrm{Na}$ sua brevidade, as fórmulas servem para mostrar diferentes estilos, o da GNR e o do mero cidadáo provinciano, que um acontecimento inaudito, mas de alcance modesto, lança para a ribalta. Mais hábil do que os colegas de ofício, foi a Eduarda quem conseguiu o desejado depoimento da figura central, o próprio bispo; com o autoritarismo vulgar na profissão, investiu com a mais tonta das perguntas, ainda que à altura das circunstâncias (111); "Entấo a perna do câo, sabe a quê?" Ao que o bispo respondeu, rendido à sedução da popularidade, com pormenores biográficos, de um passado remoto, num contexto de província e de uma rotina secular (112). A inutilidade dos assuntos, em desequilíbrio com o empolamento da mensagem, as fórmulas feitas, a dimensão da imagem, a repetição insistente, são os sustentáculos de um jornalismo pobre, pouco profissional, socialmente inútil, mas à medida de um colectivo pouco exigente. 


\section{Outras linguagens}

Uma última referência é devida a 'outras linguagens' que perpassam o mosaico de estilos em Era bom. Comecemos por códigos pesados e formais, conectados com certas formas de cultura, elitistas e selectivas na sua índole, mas enfadonhas para o leitor comum. São deles exemplo, "um recital de poesia hexamétrica em baixo-latim" (13) com que uma Fundação de cultura brinda, por mecenato, uma plateia restrita. Com maior amplitude, uma tese académica alarga o modelo. Destinada sobretudo ao pó das prateleiras, depois de lida por um destinatário escasso - "ainda não foi publicada", 19 -, esta criação cultural pende para assuntos circunscritos, minúsculos e por demais aprofundados, a ponto de caírem na insignificância - "As Disposições das Alminhas nas Encruzilhadas do Alto da Beira" como tema de Antropologia Analítica -, no âmbito de saberes a que o homem comum reage com assombro. Mas, subjacente à excepcionalidade do tema, está um estilo medíocre, um português paradoxalmente impreciso e falho de rigor - "... há-de interessar pouco que um licenciado escreva perjorativo em vez de pejorativo, árbito em lugar de árbitro, ou orquesta por orquestra”. E, no entanto, a mediocridade deste tipo de produtos é sancionada por júris internacionais, numa manifesta indiferença que parece não ter fronteiras, pela má qualidade. Estranhamente, o nível da linguagem dos trabalhos académicos parece pautar-se por uma ignorância palmar e por uma completa e tolerada falta da rigor.

Se sairmos do território estreito da cultura académica para o campo sem limites da sociedade comum, dois padróes merecem comentário; o da linguagem burocrática e o da publicidade; em campos muito distintos, ambas construíram o seu próprio protocolo.

A burocracia vive de fórmulas, de clichés repetitivos, de que a imaginação está arredada e onde a criatividade é proibida. Ao funcionário inconformado com o espartilho da profissão não está permitido mais do que 'traduzir' fórmula por fórmula, num empenho insano, mas votado ao fracasso, de criar estilo; e, por estranho paradoxo, Vaz Alves, na pele do burocrata por excelência, assumiu consigo o compromisso de náo repetir vocabulário de ofício para ofício, armado de um dicionário de sinónimos (24). Ao serviço de uma Fundação, que entendia como versão de uma empresa, redimiu-se de clichés vulgares e procurou criar os seus próprios (22):

Aos destinatários do giro da empresa preferia chamar "o cliente difuso", designação que lhe parecia preferível à de "cliente global", 
configurando os "alvos" da "oferta de produtos". Nessa conformidade (ele dizia "como tal"), o primeiro requisito que se exigia era que os colaboradores (eufemismo para "empregados") fossem capazes de "implementar" em primeiro lugar a eficácia, em segundo, a eficácia e em terceiro, a eficácia”.

Feita da força do nome e do seu atributo, a variação formular de uma empresa criou o seu padrão próprio para o triângulo fornecedor, produto $\mathrm{e}$ cliente, num leque estreito, convencional, a breve trecho desgastado, onde a imaginação escasseia como mola da tão propalada eficácia. Mesmo se limitada, a linguagem burocrática conhece nuances e campos semânticos. O burocrata, se transplantado de serviço dentro da mesma instituição, do andar administrativo para o da biblioteca, depara-se com a necessidade de mudar de estilo, e a prosa profissional regista a troca. Aí, a simples consulta de despachos em arquivo à espera de remessa confronta-o com uma realidade ainda mais formal e codificada (25):

Em resposta à prezada carta de $V^{a}$ Ex a datada de ... do corrente, cumpre-nos informar que o seu projecto denominado "Biblioteca Elementar Básica", se bem que interessante não consta actualmente das prioridades da Fundação.

Acusamos recebida a amável oferta de $\mathrm{V}^{\mathrm{a}} \mathrm{Ex}$ a que penhoradamente agradecemos, ou verificando com pesar que $\mathrm{V}^{\mathrm{a}} \mathrm{Ex}{ }^{\mathrm{a}}$ ainda náo devolveu ...

Do que, no piso da administração, parecia ainda revestido de "encanto e de império", não restava, na biblioteca, mais do que "o sombrio, descritivo e monótono" ofício. O nome e o qualificativo cediam espaço à concorrência do advérbio, "actualmente, penhoradamente, com pesar", todos eles confinados a um circuito fechado de propostas de projectos, ofertas e aquisiçôes. Aí o "cliente difuso ou global" cristaliza no tratamento de Va Ex a e o "colaborador ou empregado" ofusca-se no anonimato de um plural majestático, "cumpre-nos", "acusamos", "agradecemos".

Por flagrante contraste, a linguagem publicitária, solta de quaisquer limites que não sejam os da concretização de uma finalidade - vender -, usa da imaginação, da criação de clichés, que ela mesma, sem freio, altera e produz. Lacónica no estilo, a publicidade vive do som, do inconformismo das palavras, do artifício da rima, do tom proverbial, como incentivos à memorização involuntária. Assim, nas campanhas de produtos alimentí- 
cios, "Farofeiras no bolso / o melhor almoço" (47), "Fubá, o melhor que há!" (67); ou então o recurso ao irreal para promover o concreto, como por exemplo um automóvel (118): "Um automóvel como os outros? Não, este carro não consome combustivel. Consome fantasia, etc., atmosfera irreal, não sei quê, etc.". Ainda que oca de sentido, a publicidade vibra em sons, exclamaçôes, interrogaçóes retóricas, aproveitando as virtualidades da língua talvez tanto quanto o atractivo da imagem. A banalidade que a linguagem literária não tolera garante ao estilo mediático uma difusão inegável.

Tal como começamos, acabaremos com palavras de Zagajewski (2003, En la belleza ajena, trad. espanhola, Valência: 38), sobre a relação polémica que os vários níveis da criação literária ou linguística estabelecem entre si, e com outras criações artísticas:

O que mais ameaça os poetas não são as violentas arremetidas dos propagandistas puritanos, nem os ataques saídos da pena dos seus irmãos - romancistas (...). O mais perigoso é a indiferença, a ilimitada indiferença dos passageiros dos comboios suburbanos e dos fanáticos da televisão. O pior é quando ninguém escreve panfletos contra a poesia. 


\title{
$\mathrm{O}$ processo criativo em Era bom que trocássemos umas ideias sobre o assunto
}

\author{
Ana Paula Arnaut \\ Centro de Literatura Portuguesa/FLUC
}


(Página deixada propositadamente em branco) 
A Advertência a Era bom que trocássemos umas ideias sobre o assunto anuncia e garante que "Este livro contém particularidades irritantes para os mais acostumados. Ainda mais para os menos. Tem caricaturas. Humores. Derivaçóes. E alguns anacolutos", assim parecendo, desde o início, pretender desorientar o leitor, alertando-o para o facto de que a ficção, esta que se dá a ler, não é História mas invenção, ilusão criada (o próprio narrador afirma a determinado momento não ter conseguido inventar melhor ${ }^{1}$ ). Todavia, a verdade é que, apesar disso, se consegue um belíssimo e recognoscível retrato de tipos que povoaram (e que povoam) um espaço e um tempo de uma época.

Imitação imperfeita é certo, mas representação possível no âmbito da enciclopédia de quem se tem mostrado atento ao panorama social do Portugal pós-Revolução dos Cravos. Do que se trata, por conseguinte, não é tanto fazer doutrina e teorização de tom sério sobre um recente campo de experimentação e inovação literárias, em oposiçáo a tradicionais práticas de influência oitocentista. Trata-se, antes, de utilizar o paradigma metaficcional post-modernista para, sob uma meramente aparente ligeireza discursiva, posicionar ao nível de uma estrutura profunda os estiletes com que "leva a cabo",

uma série de ajustes de contas com o seu passado e presente de militante do PC, e ainda - o que foi muito notado - com o mundo do jornalismo contemporâneo, aqui caracterizado com toda a acidez que há um século Eça destilara a propósito dos Palma Cavalóes do tempo².

A competência semiótica exigida para a compreensão destes e de outros "ajustes de contas" traduz-se, entâo, na necessidade de descodificar a obra não apenas à luz das relaçóes paródicas que estabelece com outros textos, mas também à luz do forte impulso satírico e irónico, e por isso mais hilariantemente corrosivo, desse outro texto que é o mundo para que somos remetidos.

Entendendo por sátira a "critical representation, always comic and often caricatural, of "non-modelled reality", i.e. of real objects (their reality may

* Texto retirado e adaptado de Arnaut, 2002: 245-274.

1 Carvalho, ${ }^{5} 2003:$ 59. Afirmação feita a propósito do possível local onde Eduarda terá adquirido "um ror de palavras finas" como "Blasé, interface, intertextualidade, frontispício, new age, paralaxe, pórtico" (itálicos do autor).

2 Silvestre e Diogo, 1998: 1 (15 pp.). 
be mythical or hypothetical) which the receiver reconstructs as the referents of the message" 3 , parece-nos pertinente identificar três importantes núcleos de personagens-tipo. Núcleos a partir das quais se torna possível estabelecer laços com um colectivo de gentes cuja ascensão decorreu dos libertários tempos de Abril. Podemos até nem conhecer os rostos de cada uma delas, mas sabemos os tiques acumulados e cultivados e isso basta para que se despolete o processo mimético, o processo de uma representação, se não verdadeira, pelo menos verosímil (si non é vero é bene trovatto!).

Salvaguardando as devidas distâncias pictóricas e alegóricas, da mesma maneira que, em Era bom que trocássemos umas ideias sobre o assunto, Jorge Matos olha para a Caça ao Leão (de Delacroix) e se lembra da gravura "sobre a revolução de 1830, com a demoiselle aux grosses mamelles sobressaindo, branca, entre beligerantes irados, escopetas, cadáveres e desolaçóes" ${ }^{\text {", }}$ e que não havia podido comprar visto ter sido apreendida pela PIDE, também o leitor desta obra ao olhar, lendo, personagens como Rui Vaz Alves, Eduarda Galvão ou Joel Strosse Neves (e outras personagens colaterais, mas afins), activa certas estruturas cognitivas que lhe trazem à mente uma galeria de figuras bem interessantes.

Referimo-nos aos que, na linha do espírito jocoso sempre latente na obra, podemos designar, numa primeira categoria, de tipo do parolo empresário da cultura. Rui Alves, bem falante de vazio conteúdo (e cujo discurso por vezes se corrige ${ }^{5}$ ), é, pois, o tipo do homem pseudo-culto; do género dos que obtêm no estrangeiro a sua licenciatura, no caso sobre " "As Disposiçóes das Alminhas nas Encruzilhadas do Alto da Beira»", por incapacidade de o fazer num Portugal onde, provavelmente, se detectariam os erros de ortografia. No seu braço, o eventual bom gosto de um relógio

3 Ben-Porat, apud Hutcheon, 1985: 49.

4 Carvalho, ${ }^{5}$ 2003: 46.

5 São várias as oportunidades aproveitadas pelo narrador para correcção do discurso desta e de outras personagens: "Nessa conformidade (ele [Rui Alves] dizia "como tal») o primeiro requisito que se exigia era que os colaboradores (eufemismo para "empregados») fossem capazes de «implementar, em primeiro lugar a eficácia, em segundo a eficácia e em terceiro, a eficácia", "Era um mau prenúncio (pernúncio [Eduarda]). Haveria uma catástrofe, um dilúvio com chuva de enxofre e depois o mundo seria melhor", "AAinda bem que o encontro, porque era precisamente consigo ("com você" [Eduarda]) que eu queria falar", p.61; "Eu vinha pedir ao senhor doutor (sôtor [Eduarda]) um grande favor", "O sargento da GNR declarou, de bigodes ameaçadores, que o caso (a "ocorrência") era da competência dos tribunais", p.109; "Depois, respirou fundo, da fadiga, ajeitou o braço que trazia ao peito e pediu licença para dormir (ele [o bispo de Grudemil] dizia: "para se concentrar») um pedacinho" (Carvalho, ${ }^{5} 2003:$ 22, 38, 72, 111). 
Rolex é traído pela coexistência pacífica, mas promíscua, de "uma daquelas pulseiras com duas esferazitas de metal", supostamente capazes de afastar reumatismos, "dar energia e evitar doenças e não sei se maus-olhados", que há anos fizeram moda entre gente crédula e incauta.

Adjacente ao delinear deste retrato, completando-o extensionalmente e de um modo que permite, porventura arrevesadamente, uma mais lata imiscuição crítica no papel de algumas das nossas veras Instituiçôes, os dados facultados sobre a Fundação, de cuja administração é vogal, revelam (desde a prioridade dos subsídios a atribuir até às exemplares secretárias que ali labutam) a tacanhez e a falta de iniciativa no que diz respeito a aspectos culturais?

Num segundo grupo, salientemos o tipo da (pseudo) jornalista incompetente e arrivista, representante também, via revistas Modelar e Reflex, de um género de imprensa de influência estrangeira, de cujo nome o autor afirma não querer recordar-se mas que facilmente identificamos com as 'Holas' expostas nas bancas de jornais.

Os traços iniciais desta personagem, sobre a qual o narrador confessa não querer "entrar em muitos pormenores psicológicos, porque tenho pressa, e prometi náo aprofundar em excesso esta figura" (e de quem sente por vezes vontade de "dar cabo"), mesmo sendo facultados "a pinceladas rápidas, de zarcão, despachadamente”, permitem, contudo, e desde logo, induzir o perfil ridiculamente oportunista (que será progressivamente completado de modo sempre mais acintoso) dos muitos a quem vai dando jeito, ainda hoje, dedicar-se mais à cultura ${ }^{8}$.

Em comentário com o qual não concordamos inteiramente, Linda Santos Costa sustenta:

6 Carvalho, ${ }^{5} 2003$ : 18-22. Não esqueçamos a sua capacidade de criar frases originalíssimas (!) do tipo " "Laissez faire! Laissez passer»", em artigos célebres, género "A mão invisível actua com pés de lâ»”.

7 Os critérios que presidem à atribuição de subsídios estendem-se ironicamente pelo " "dignificante»" de "uma exposição de colchas bordadas à mão pela Marquesa de Valverde, um curso de ikebana, ou uma conferência sobre heráldica” (aduza-se, ainda, que a mediatização pode operar o milagre de arrumar os Marcos Paulos da época nesta mesma categoria), enquanto "um espectáculo da Cornucópia, um recital de versos de Alexandre O’Neill, ou um filme português (...) sofreriam a nota de «interessante mas não prioritário”; "Um livro de poesia de um jovem autor seria inexistente" (Carvalho, $\left.{ }^{5} 2003: 23-24\right)$. Sobre a questão do árduo trabalho das secretárias que fazem fichas "à mão, à razão de uma ou duas fichas por dia" porque, afinal, as "práticas Tarot e conversações" sobre a mesma matéria revestem-se de bem maior importância (!), ver ibid.: 138-139.

8 Ver ibid.: 61, 29, 58 e 104 para o desejo de dar cabo de Eduarda. 
Eduarda Galvão é a ocasiáo, que o autor se oferece, para exercitar o seu pendor moralista (todo o humorista esconde um moralista que se ignora) e ajustar contas com um mundo e valores que lhe são estranhos (no duplo sentido de desconhecidos e alheios). A sátira é violenta e conseguida, mas destoa do tom geral do livro. Dir-se-ia que Eduarda Galvão e Vera Quitério não pertencem, por razôes opostas, ao espírito que presidiu à criação do romance?.

Ao contrário do que afirma a autora, não julgamos que o tom de virulência utilizado destoa do que perpassa a globalidade do texto. A própria bonomia com que é tratada Vera Quitério, se é certo que se afasta desse tom satírico, revela-se, contudo, necessária como ilustraçáo complementar contrastiva e, por isso, susceptível de aumentar o grau da crítica exercida sobre a degenerescência de certos valores de esquerda, de certos valores de Abril em termos mais englobantes. Nestes se incluem os que satiriza a partir de Eduarda Galvão, o que nos leva a discordar, também, da alegação de que o ajuste de contas que faz a partir desta personagem diga respeito a um mundo que lhe é desconhecido e alheio.

Afinal de contas, o autor assistiu e viveu na leitura dos jornais ao aparecimento e ascensão das Eduardas Galvão de uma imprensa seduzida por bombásticas notícias do género "cão mordido por um bispo"; as mesmas Eduardas que não morrerão "tão cedo, nem no romance nem fora dele" 10 . As mesmas que, ainda, revelando-se incapazes de fazer entrevistas, na língua materna ou em outra (caso da entrevista ao escafandrista Bertrand L'Église), se arrogam o direito e a capacidade de vestir a pele do crítico literário que, em duvidosas e sempre caricatas secçôes de revistas recomendam a leitura de Alberto Helder (sic) e "outros poetas «modernos"”.

Este comentário-deslize, que ajuda o narrador a traçar o retrato robot da jornalista ignorante e oportunista, encontra-se perfeitamente sintonizado com as características que, posteriormente, ressaltarão também dos excertos irónico-jocosos em que se dá conta da entrevista à escritora Agustina Bessa Luís:

Foi a promissora Eduarda que mandaram ao Minho, entrevistar uma certa Agustina Bessa Luís, de quem na altura se falava muito. Ela leu um terço de $A$ Sibila no comboio e gostou muito do primeiro terço desse terço;

\footnotetext{
9 Costa, 1995: 10.

10 Carvalho, ${ }^{5}$ 2003: 212.
} 
Quando, já no comboio, Eduarda consultou os seus apontamentos, sentiu-se muito confundida. Náo conseguia reconstituir a maior parte das frases. Não ousara pedir autorizaçáo para usar o gravador e agora via-se com umas folhas garatujadas que the pareciam não corresponder exactamente ao que lá na revista esperavam de uma conversa com Agustina. E sobressaltou-se, porque se lembrou dum episódio ocorrido com um colega, recentemente despedido da Reflex, por causa de algumas imprecisóes mal compreendidas pela chefia ${ }^{11}$.

Este episódio é seguidamente relatado, de forma a ilustrar a extensão do problema da ignorância no terreno jornalístico. $\mathrm{O}$ entrevistado é, agora, um escritor de tipo abjeccionista que, entre outras coisas, conta ao jovem entrevistador ter sido "colega de curso de Gomes Eanes de Zurara, num colégio de Messejana, que costumavam ambos faltar às aulas para ir às bananas e aos abacates, numa quinta que era do pai do intendente Pina Manique (aquele dos automóveis...)"!.

A ironia virulenta que sempre acompanha a vertente satírica, e nunca isenta de interessantíssimas contaminaçóes culturalmente humorísticas, é exercida, ainda e sobretudo, a propósito da terceira categoria, a do tipo do cidadão pseudo-intelectual e pseudo-empenhado, aspirante ao que vulgarmente designamos por esquerda festiva, na pessoa de Joel Strosse Neves.

Em episódio que assume "repleto de expedientes literários", e por isso poupando "o leitor a mais um" (apesar de confessar que "Vinha a calhar agora um sonho, com multidóes, cânticos e bandeiras e umas irrupçóes disparatadas" de tonalidades surrealistas ${ }^{12}$ ), a personagem começa a ser desenhada nos acordes ideologicamente caricatos que se consubstanciarão no decorrer da narrativa.

11 Ibid.: 118 e 144-145, respectivamente; ver 58 para a menção a Alberto Helder; 65-66, 71-73, 85-88 para a incapacidade de entrevistar o escafandrista Bertrand L'Église e 145-146 para o episódio da entrevista com o escritor de tipo abjeccionista.

A propósito deste e de outros tipos criados, ver Cotrim 1996: 38-49. A propósito das Eduardas do tempo que corre, comenta Mário de Carvalho: "Substituiu-se a crítica pelo comentário jornalístico. Há, em dado momento, um retrocesso. Quem aparece a fazer crítica não tem a mesma espessura de conhecimento, de cultura, de capacidade de associação, de sensibilidade em relaçáo aos textos (...). Instalou-se muito desconhecimento da nossa literatura, às vezes até por falta de formação académica das pessoas que fazem esse trabalho" (ibid.: 46-47).

12 Carvalho, ${ }^{5}$ 2003: 33. 
O fascínio, há muito adormecido, pela envolvência misteriosa que, por alturas da ditadura salazarista, rodeava o grupo de esquerda a que pertencia Jorge Matos, e decorrente mais do desejo de sair do medíocre anonimato em que vivia e entrar no "panteão dos heróis" do que de fortes e arreigadas convicçóes políticas ${ }^{13}$, é acordado em Joel Neves por mero acaso. A revelação acontece quando, em gesto classificado como "bastante inspirador", descobre na estante alguns dos livros, agora empoeirados, que, para impressionar, comprara em tempos de juventude universitária.

No presente, como no passado, fica todavia claro que o hábito não faz o monge. O desajuste que Joel ilustra, entre o que se quer parecer e o que efectivamente se é, traduz-se, embrionariamente, entre outros exemplos, na incapacidade para ler um Engels que se fecha sem cerimónia e se larga na alcatifa, ou para ler uma Ça ira! que, devidamente enrolada, termina a servir de interessante arma mortífera contra as moscas ${ }^{14}$.

É, contudo, a partir da sua decisão para ingressar nas fileiras do PCP que mais veementemente se processa o ajuste de contas do autor, quer em relação ao Partido quer no que respeita a extemporâneas tentativas de adesão da parte de certas pessoas. Essas em que a ausência de conviç̧óes político-ideológicas é resolvida por um desmesurado e anacrónico desejo de pertencer a um grupo que foi, outrora, protagonista de uma história empenhada. O mesmo grupo que hoje, o de agora e o do presente de enunciação, respeitante ao ano de 1994, parece querer ser frequentado, ad exemplum, por 'tipos' para quem ser de esquerda é uma moda marginal (de que fazem parte, entre outros sinais, a ostentação de certos livros ideologicamente conotados, a ida notada à festa do Avante ou a frequência de determinados locais) e, por conseguinte, susceptível de facultar, pela diferença, estatuto destacado no cenário social coetâneo.

13 Ibid.: 51-53. A mitificação de um futuro papel de relevo na actividade partidária encontra-se bem patente nos seguintes excertos: "a palavra "camarada» tomava cada vez mais para ele uma conotação ao mesmo tempo heróica e ternurenta. Ao passar em frente do Hotel Vitória imaginava o movimento lá dentro, tenso, transpirado com reuniôes, conversas políticas, leituras comentadas de Lénine, preparação de movimentos sociais, fraternidades de operários e intelectuais, invenção meticulosa e científica de palavras de ordem... (...). E via-se numa daquelas reuniōes, com o tecto abaixado pelo acúmulo algodoado dos fumos de cigarro, debruçado sobre um mapa de Lisboa, a conspirar. (...)" (139-140); "Ele iria contar tudo à classe operária. Iria explicar que espécie de sujeito era Rui Alves, iria denunciar os podres da Fundação, dissecar a sua natureza de classe, oferecer-se para escrever um artigo fulminador para o Avante!" (183).

14 Ibid.: 32, 42-43. 
O efeito de caricatura satírica que se obtém resulta, pois, por um lado, não só da exagerada vontade de militância de Joel Neves, mas também da sua crença na manutençáo de uma linha de sigilo e de uma linha de cunha recomendada ${ }^{15}$. Estas transformam o percurso de adesão ao Partido numa espécie de anacrónica e injustificável secreta odisseia repleta de humor, na medida em que, consabidamente, os tempos democráticos tornaram o Partido perfeitamente legal, legítimo e aberto a novos militantes. Por outro lado, resulta outrossim, e de forma igualmente interessante, de desenhos colaterais que a iniciativa da personagem faculta.

Referimo-nos ao facto de, a propósito, se fazer desfilar um leque de personagens-figuras, como Vitorino Nunes, Júlio Baptista, o balofo advogado Heitor do Carmo Velho, o professor de grego que convenciona chamar-se Reboredo, ou o próprio Jorge Matos. Figuras bem elucidativas, alvitramos, da degenerescência de valores, do desinteresse pela política na sua essência e do fosso entre os ideais de esquerda e a sua prática efectiva, num momento em que o real panorama político tem vindo, de facto, a ser marcado mais por guerrilhas inter e intra-partidos e por (hipócritas) desejos de ascensão pessoal e menos pelo zelo na defesa séria de sérios problemas.

As pressuposiçóes que anteriormente tecemos afiguram-se-nos passíveis de caucionação, por exemplo, pelo relato da reunião "subordinada ao tema "O Partido, as políticas de educação e o momento político"”. Reunião onde algumas das escassas, e aborrecidas, vinte pessoas aí presentes aproveitam o oportuno momento do discurso de Júlio Baptista para se esgueirarem, enquanto as restantes acatam, agradecidas e sorridentes, a não menos oportuna exclamação de "«já são oito horas!»", que dá por findo o pouco ou nada profícuo encontro. Arrumadas as pastas e recolhidos os papéis, anula-se definitivamente qualquer possibilidade de alcançar resultados efectivos quer no que respeita ao cerne da reuniáo quer no que concerne à possibilidade de o hesitante Vitorino Nunes, arrastado também para a 'secreta odisseia', comunicar o desejo de Joel Neves ${ }^{16}$.

$\mathrm{O}$ que assim sub-repticiamente ressalta deste episódio é um acérrimo ataque ao grupo militante para quem o Partido parece ter apenas uma

15 Entre o reconhecimento de Jorge Matos (ibid.: 44), que parece despoletar a decisão de aderir ao PCP (54), e o derradeiro encontro entre ambos no bar sugestivamente nomeado A OFICINA (202-210) ocorre uma série de diálogos cujo pendor caricatural é, por vezes, realçado por breves informações que, à laia de indicações cénicas, numa evidente contaminação pelo género dramático, se colocam entre parênteses $(69,78)$.

16 Ibid.: 126-128. 
função decorativa. Esta linha crítica estende-se, ainda, pela forma como se narra o jantar no Solar do Macedo, local de encontro marcado de personagens já nossas conhecidas e espaço que "Um cidadão desprevenido" facilmente classificaria de

tasca infecta. E teria razão. Essa era de resto a opinião geral dos frequentadores das quintas-feiras, a quem a sordidez e a pobreza do local agradavam sobremaneira. Eles estavam fartos de bifes, queriam era peixe frito; estavam fartos de Periquita, queriam era tintol, mesmo com um picozinho; estavam fartos de napas almofadadas, queriam era cadeiras de pau, ou bancos com um buraquinho redondo de enfiar o dedo ${ }^{17}$.

O repasto que periodicamente aqui decorre, e que vagamente traz à memória (numa relação inversa já que esse pretendia ser um esforço de vida social sofisticada) o célebre episódio do jantar do Hotel Central em $O s$ Maias, de Eça de Queirós, traduz-se numa sinuosa estratégia de crítica aos que deveriam defender os ideais da classe trabalhadora mas que, na prática, acabam por brincar ao proletariado uma vez por semana.

Mesmo aceitando, na sequência do que já havia advertido em Os Alferes, que estas histórias possam ser "inventadas de ponta a ponta" ${ }^{18}$, o certo é que o leitor coevo não pode deixar de considerar que elas contêm, não obstante, um mínimo de referências que as torna recognoscíveis e que, por isso, as faz parecer plausíveis e possíveis.

Não nos parece despiciendo acrescentar, pois, que na criação do efeito de um mundo possível na obra em apreço ganha papel de relevo, por exemplo, e para além dos traços histórico-geográficos em pano de fundo, o facto de uma figura do mundo real, Agustina Bessa Luís, ser chamada ao território da ficção onde interage com Eduarda Galvão, uma personagem do mundo de pape ${ }^{19}$. A criação possível é da inteira responsabilidade da entidade que rege o discurso ${ }^{20}$, que revela "an extreme self-consciousness

\footnotetext{
17 Ibid.: 120-121.

18 Carvalho, 1989 ("Nota do autor").

19 Carvalho, 1989: 143-144.

20 A propósito da cadeia de Pinheiro da Cruz, onde se encontra preso Cláudio Ribeiro Neves, e reafirmando abertamente as vantagens da focalização omnisciente, comenta, por exemplo, "Joel Strosse não conhece todo este percurso, aqui explicado pelo à-vontade do omnisciente narrador, o qual, se a cadeia de Pinheiro da Cruz não for exactamente assim, convida desde já os Serviços Prisionais a conformarem-se ao texto, ou pelo menos a absterem-se de polémicas incómodas e derivativas do que lhes interessa a eles e a mim”, ibid.: 35.
} 
about language, literary form and the act of writing fictions; a pervasive insecurity about the relationship of fiction to reality; a parodic, playful, excessive or deceptively naïve style of writing" ${ }^{21}$.

Marcas facilmente identificáveis na obra em apreço nos múltiplos momentos em que se materializam as "tentaçóes de criminalidade literária"22, passíveis de corroboração, por exemplo, no seguinte excerto:

Agora há uma passagem muito rápida em que se contam uns pormenores relevantes que me convém despachar antes de rematar a primeira parte do livro. Daqui a bocado preciso de dirigir uma pequena interpelação ao Joel Strosse, e, até lá, não convém que fique nada por elucidar. Se não fosse abusar, até usava alíneas e limitava-me a substantivos. Mas como costumo ficar incomodado das habilidades modernaças, armadas ao pingarelho, com que a minha concisão poderia confundir-se, forço-me, por disciplina, a debitar texto, embora escasso. Onde é que eu ia? ${ }^{23}$.

Não concordamos, por conseguinte, com a opiniáo expressa por Osvaldo Silvestre quando, ao assinalar o "ímpeto desconstrutivo" de Mário de Carvalho, considera curioso que este não o tenha conduzido "à prática da metaficção tão frequente nos nossos dias", reservando a referência a um "afloramento metaficcional" para o caso do epílogo de Casos do Beco das Sardinheiras, momento em que o autor é visitado pelas personagens criada $^{24}$. Em nossa opinião, este procedimento é, no entanto, apenas mais um modo, extremo sem dúvida, de chamar a atenção para a obra como construto ficcional.

Curiosamente, em Era bom que trocássemos umas ideias obre o assunto, onde bastas vezes indicia a sua posição e a sua função de autor totalitário na orquestração e na manipulação do discurso, esta forma extrema de metaficção é apenas exposta como ensaio não conseguido. Deslizando do seu "Olimpo" e instalando-se na "sala pelintra" de Joel Strosse afirma tentar chegar à fala com a personagem, "interpelá-lo e tratá-lo, por instantes fugazes, na segunda pessoa do singular"; apercebe-se, todavia, "de que é inútil querer chegar ao contacto de Joel Strosse" porque, numa inversão de

\footnotetext{
21 Waugh, 1988: 2.

22 Carvalho, ${ }^{5}$ 2003: 104.

23 Ibid.: 112 .

24 Ver Silvestre, 1998: 218.
} 
ontologias existenciais que, apesar disso, acabam por traçar a linha divisória entre realidade e ficção, "Joel existe, eu não"25.

Para além dos exemplos que temos vindo a registar, e de outros que posteriormente mencionaremos, o exercício metaficcional acontece, também, quando evidencia plena consciência da diferença entre o tempo do discurso e o tempo da história ("Por um instante fugaz - tanto que leva mais tempo a contar do que a acontecer - tentou recordar as suas aulas de judo, em adolescente, no Lisboa Ginásio"), ou quando elucida que um "como» que utiliza "não introduz metáforas, por ora, que as reservo para mais tarde, talvez dedicando-lhes meio capítulo ou um inteiro, para conferir um toque de literariedade petite-bourgeoise, muito vendável, a este texto...”.

A auto-reflexividade ocorre também quando, revelando que os pensamentos grafados não são seus, o narrador permite entrever a contaminação pessoal a que os sujeita: "Estes pensamentos não são meus que não quero ferir susceptibilidades de criadores de dobermans, mas eram mais ou menos - descontando a parte do Ray Bradbury - os de Joel Strosse."

Em outros momentos, confessa omitir uma conversa "completamente destituída de importância" entre Eduarda e Cremilde "a bem da economia da história" ou admite náo dizer tudo "sobre a mobília" da sala de Jorge Matos porque "ir mais longe era exagerar" 26.

As "particularidades irritantes para os mais acostumados", referidas na Advertência, são também patentes, e confirmadas, pela confissão de lhe apetecer "um derivativo de deixar assentar os nervos" 27.

Sendo pois verdade que a auto-reflexividade em Era bom que trocássemos umas ideias sobre o assunto se revela como empenho de base que acompanha a construção-caracterização satírica das personagens (e, pour cause, do enredo em geral), a que se alia a devida ironia e o consequente afastamento da instância reguladora do discurso, não é menos verdade que de todo este processo ressaltam relaçóes intertextualmente paródicas com certas tradições literárias do passado. A descodificação destas relaçôes não compete exclusivamente às capacidades hermenêuticas e enciclopédicas do leitor, já que, numa espécie de relaçáo edipiana morta à nascença e posta a descoberto, cabe também ao narrador, que manifestamente assume, expondo à flor da tessitura do seu discurso, a ausência das características do texto-estilo

\footnotetext{
25 Carvalho, ${ }^{5} 2003: 114$.

26 Ibid.: 27, 50, 34, 38 e 47, respectivamente.

27 Ibid.: 81 .
} 
parodiado. Este, contudo, acaba por ser incorporado, assim ilustrando essa já tantas vezes notada contradição do Post-Modernismo. Mesmo quando parece seguir-se essa tradição, o desnudamento metaficcional do processo obsta à consecução do pastiche, impondo, segundo cremos, o devido afastamento irónico.

É assim que, por exemplo, na apresentação de personagens como Rui Alves e Joel Neves, se convocam (antecedendo, acompanhando e muitas vezes prolongando a caracterização) processos e técnicas narrativas cuja aplicaçáo deve indubitavelmente ser lida como afastamento crítico, mais ou menos velado, de práticas literárias que já fizeram moda e cânone no século XIX:

Ora, no sexto andar do edifício aludido, num gabinete amplo e com decoração assim-assim, que seria ocioso especificar, fitam-se duas personagens: uma do lado do proprietário da secretária, a outra, do outro. O titular do gabinete e anfitriāo chama-se Rui Vaz Alves, é vogal da administração e dirige o "departamento de contacto» da casa; o outro chama-se Joel Strosse Neves, estancia habitualmente num dos pisos de baixo e tem, sobre o primeiro, a única vantagem de ser o protagonista desta história. Como, neste breve relance, os dois homens estão apenas a olhar um para o outro, e não adiantam nada, eu aproveito a ocasiáo para me prevalecer duma velha tradiçáo literária e apresentá-los ao leitor, com o acrescento dumas circunstâncias esclarecedoras ${ }^{28}$.

Antes, já o narrador confessara ter falhado a ocasião de "«fazer progredir o romance»”, na medida em que, por já ir na página dezasseis (por acaso é a página dezoito) se encontra em "atraso sobre o momento em que os teóricos da escrita criativa obrigam ao início da acção". Facto que o leva a ver-se "obrigado" a deixar consideraçóes que vinha tecendo "para passar de chofre ao movimento, ao enredo. Na página três já deveria haver alguém surpreendido, amado, ou morto".

Se no excerto que acima transcrevemos se faz uma paródia à convenção, se exorcizam os mandamentos do passado literário, e as regras de bem compor um romance, pela incorporaçáo distanciada e explícita de técnicas de apresentação de personagens, outros momentos há em que o exorcismo se exerce através de uma clara e franca rejeiçáo de outros preceitos, no caso os da minuciosa estética realista.

28 Carvalho, ${ }^{5}$ 2003: 18 (destacados nossos). 
Assim acontece quando, a propósito da sede da revista Modelar e, posteriormente, do ridículo episódio de caça às moscas no gabinete de Bernardo Veloso, na revista Reflex, comenta:

Como seria interessante aprofundar este pequeno microcosmos naquele andar do Forno do Tijolo, dividido por tabiques de pasta de madeira, onde incessantemente ronronava um fax quando os telefones o deixavam ouvir e as letras corriam céleres nas pantalhas dos monitores... Seria um tratado de vida. Porém, não é para isso que eu aqui estou. Interessa-me tão só a Eduarda Galvão;

A brincadeira prossegue até à hora do jantar, sobrando ainda algumas moscas para o dia seguinte. Um escritor estilista dedicaria umas boas três páginas a descrevê-la, com gestos, saltos, risinhos, urros e queda de objectos. Eu por aqui me fico. Não quero abusar das oportunidades. Basta-me perscrutar o olhar de Bernardo e anotar que ele se mostra sinceramente reconhecido para com $\mathrm{Eva}^{29}$.

A assunção do controlo narrativo que o narrador exerce permite-lhe, ainda, atestar a impossibilidade de continuar a tradiçáo de um certo Romantismo de tempos camilianos:

A segunda parte queria eu começá-la logo de rijo, e em festa. Tinha ensejado para este lugar uma vasta elipse, de proporçóes conformes aos estilos consabidos da Retórica e da Geometria. Mas, antes, arrebatou-me um escrúpulo cadastral de apontar, em sinopse, o que ocorreu no interim, com prejuízo da tal figura de estilo, que fica a dever à perfeição. Teria a vida facilitada se os acontecimentos houvessem evolucionado de molde a eu poder dizer como Camilo «decorreram dez meses sem sucesso digno de mençấo...», deixando o tempo, entretanto, a trabalhar para o romancista.

Mas o que aconteceu, aconteceu, e náo lhe falta a sua pertinência. Conta-se em poucas penadas ${ }^{30}$.

Apesar de todas as advertências para o estatuto ficcional do que conta, há, contudo, outros momentos em que o narrador afirma um enraizamento

\footnotetext{
29 Ibid.: 57 e 84, respectivamente (destacados nossos).

30 Ibid.: 117 (destacados nossos).
} 
no real. Depois de se ter preparado "para descrever melhor o gabinete de Bernardo", e quando "já ensaiava vários ângulos, com movimentos cinematográficos do olhar, a que não faltava um contra-picado, (...) alguém, truz, truz!, bateu à porta e (...) estragou os arranjos", acaba por observar que "A vida, não raro, ficciona, devaneia, absurdiza e eu hei-de conformar-me a ela, mais do que ao famoso pacto de verosimilhança outorgado com o leitor" 31 .

Numa abordagem passível de ser considerada demasiado redutora poder-se-ia encarar este tipo de auto-referencialidade, que pelas paródicas relações intertextuais remete para o mundo da própria literatura, como um atestado do pendor formalista das obras. No entanto, e de acordo com a linha de raciocínio que vimos seguindo, cremos que se deve proceder à derrogação de tal hipótese. Convocamos, a propósito, duas observaçóes dignas de nota.

Em primeiro lugar, nos casos em que a apropriaçáo textual se processa entre duas obras singulares (a. o Ulysses de Joyce e b. a Odisseia de Homero, para referir dois dos mais conhecidos exemplos), acreditamos na necessidade de ter em conta que, sendo certo verificar-se a remissão de um para outro texto, de a. para b., não é menos certo que, por sua vez, b. reenvia para a representação de um determinado cenário-mundo que, em diferido e salvaguardadas as devidas distâncias temporais e estético-ideológicas, se imita.

Parece acontecer, pois, um duplo enraizamento ontológico, no texto que se imita e, em segunda mão, no mundo que este representa, veículo eventual para o(s) 'passeio(s) inferencial(ais)', satírico(s) ou não, propugnado(s) por Umberto Eco ${ }^{32}$.

Em segundo lugar, no caso concreto de Era bom que trocássemos umas ideias sobre o assunto, a saída do espartilho formalista parece processar-se não só pela já mencionada possibilidade de identificarmos certas personagens com gente-tipos coetaneamente reais, mas também porque determinados segmentos do texto ecoam lascas de cenários e de tipos já patentes em outros textos, no caso os ecianos. Estes permitem reiterar, numa representação diferida que se projecta num futuro que é o presente em que vivemos (e, no caso, abrindo caminho para a sátira), a ligação a uma realidade extra-literária.

Esta, mais de um século decorrido, suscita, apesar de tudo, críticas afins: às limitaçóes de mentalidade e à diferença entre o que se é e o que se

\footnotetext{
31 Ibid.: 84 (destacados nossos).

32 Eco, 1979: 126-127.
} 
quer parecer e, principalmente, à sordidez e à pouca seriedade de ambientes jornalísticos, antros de venalidade e de incompetência.

A extrapolação crítica é permitida, como já referimos, quer pela caracterização de certas personagens quer pela descrição de determinados ambientes (muitas vezes complemento e/ou extensão de traços marcantes da gente que os povoa). Eduarda Galvão, por exemplo (e do mesmo modo os ambientes jornalísticos por onde se movimenta), é, sem dúvida, o exemplo flagrante do prolongamento possível do tipo do jornalista, oportunista e sem escrúpulos, de nítido recorte eciano.

A prosaica máxima que o narrador de Os Maias coloca na boca de Palma Cavalão ("O mal não foi grande, e sempre se fez alguma coisa pela porca da vida" ${ }^{33}$ ) é, em Eduarda, uma espécie de jeito especial que lhe permite alcançar com sucesso, e sem olhar a meios, os fins desejados. Tal acontece quando, ainda na Revista Modelar, "em apenas dois meses", consegue "quatro vitórias importantes para o ego": para além de ver o seu nome citado no Expresso, causa uma depressão na jornalista fumadora que assim se vê obrigada a meter baixa; seduz o fotógrafo numismata, "deixando que a pretendente o soubesse (...), mas escondendo o facto ao director"; e martiriza "uma jovem estagiária, licenciada em Química (...) e a quem começou por rosnar, à laia de recepção: «Química, hem? Ah, estas vocaçóes falhadas..." "34.

A hipocrisia da personagem é ainda bem patente nesse jocoso excerto onde se dá conta da sua mudança de atitude em relação a um rapaz que, inicialmente, lhe parece repugnante mas que, depois de o saber editor da Revista Reflex, começa a interessar-lhe:

A metamorfose de Eduarda foi tão rápida que eu suspeito de que andou por ali uma fada, que fez trabalhar a varinha competente nesse preciso momento, operando a metamorfose de Eduarda após ter operado a do batráquio. Não sei se o alvejado reparou na maravilha, mas Eduarda, que não tinha saúde para desistências, cogitou: "Tás aqui, 'tás no papo!»"

A falta de ética jornalística, numa completa ausência de regras deontológicas, é passível de ser ilustrada de modo mais consistente quando, impe-

\footnotetext{
33 Queirós, s./d.: 542.

34 Carvalho, ${ }^{5}$ 2003: 57.

35 Ibid.: 60 ..
} 
dida de ouvir as respostas dadas pelo escafandrista que pretendia tentar a travessia do Tejo (em virtude de deficiência na gravação, quase parecendo que "os elementos e o material japonês" se tinham conjurado contra ela ${ }^{36}$ ), a jornalista de Era bom que trocássemos umas ideias sobre o assunto não hesita em aceitar a sugestấo de Jorge Matos:

- Náo importa. Inventam-se aí umas coisas. Desde que sejam lisonjeiras para o homem, ele até fica feliz. Ora senta-te lá ao computador e escreve. Eu, depois, corrijo-te a ortografia.

E foi ditando perguntas e respostas $(. . .)^{37}$.

Episódio que, agora, traz à memória esse outro em que Agostinho Pinheiro, redactor da Voz do Distrito em O Crime do Padre Amaro, recorda a João Eduardo a recomendação que, na véspera, lhe havia sido feita pelo doutor Godinho, director do jornal: "Em tudo que cheirar a padre, para baixo! Havendo escândalo, conta-se! Não havendo, inventa-se!" 38 .

A distância que metaficcionalmente se instaura nos segmentos de Era bom que trocássemos umas ideias sobre o assuntos em que, de modo diverso, se convocam parcerias com autores do passado literário (pela negação, pela ausência inscrita ou pela apropriação paródica das características do modelo/estilo imitado), permite, por um lado, a instauração da mimese de processo $^{39}$. Por outro lado, em simultâneo, os laços intertextuais estabelecidos possibilitam a reflexáo sobre o facto de que, sendo outro o contexto sócio-cultural, são também outras as exigências e as modas dos ventos literários que percorrem o cenário coevo e que assolam os gostos do público leitor.

De acordo com Carlos Reis,

o que aqui se passa algo tem a ver com a narratologia (...) no sentido em que aquilo que este romance evidencia é a exaustão de um género (ou, se se quiser ser mais moderado, os riscos de exaustão que ele corre), por força de uma institucionalizaçáo que decorre também dos termos em que foi apropriado pela teoria literária e pelas instituiçóes (...) que o acolhem. Deste modo, como romancista, M.C. antecipa-

36 Ibid. 80.

37 Ibid. 86 (destacados nossos).

38 Queirós, 2000: 409 (destacados nossos).

39 Respeitante à exposição/desnudamento dos códigos e meandros que deverão nortear a aproximação ao texto (ver Hutcheon, 1984: 55). 
-se à pergunta que muitas vezes ouvimos em aulas e em sessóes de esclarecimento várias: "o autor saberia mesmo que estava a utilizar uma focalização?» A pergunta é idiota e M.C. responde a ela pelo seu reverso, ou seja, mostrando o seu absurdo, do ponto de vista da escrita em acção ${ }^{40}$.

40 Reis 1996: 23 (destacados do autor). 


\title{
Intertextualidade e Metaficção em Fantasia para dois Coronéis e uma Piscina, de Mário de Carvalho
}

\author{
Rosana Baptista dos Santos \\ Universidade Federal de Lavras
}


(Página deixada propositadamente em branco) 
Através da ironia ${ }^{1}$ e da paródia, ${ }^{2}$ o romance Fantasia para dois coronéis e uma piscina ${ }^{3}$ procura representar as particularidades (sobretudo as negativas) da sociedade portuguesa contemporânea. O termo "fantasia", que consta do título, refere-se aos vários eventos extraordinários que dominam a narrativa e instauram um ritmo próprio do sonho e da ilusão. Construído como um "mosaico de citaçôes", ${ }_{4}$ o romance procura estabelecer uma relação entre os textos clássicos greco-latinos, a tradição literária portuguesa e a narrativa contemporânea, por meio de referências diretas e indiretas a vários autores como Homero, Aristóteles, Petrônio, Camões dentre outros; e, também, a temas e estruturas próprias da tradição literária greco-latina, como o apelo à Musa, a estratégia da aparição inesperada de um deus ex machina, a sobreposição de diferentes narrativas, a demonstraçấo dos "bastidores" da criação artística e o diálogo com o leitor. Essa narrativa que acolhe diversos outros "géneros de escrita - novela, crónica, cinema e até poesia" ${ }^{5}$-, é classificada pelo autor de cronovelema, ${ }^{6}$ na medida em que "procurou ser um desconcertante festival de ilusionismo". O termo cronovelema é, também, um neologismo de inspiração clássica que exprime a idéia de uma "viagem literária pelo tempo". Tal sentido é evidenciado no episódio em que simultaneamente uma personagem percorre os campos portugueses à procura de um determinado tiroteio, enquanto o narrador, que se denomina autor, e o leitor, repetidamente convocado a também "viajar", "deslizam" para outro local a fim de observarem outro personagem.

* Agradeço à Capes (Coordenação de Aperfeiçoamento Pessoal de Nível Superior) pela concessão de uma bolsa de Doutorado Sanduíche para a realização da pesquisa sobre a obra de Mário de Carvalho, na Universidade de Coimbra, que resultou na publicação deste capítulo de livro.

1 Cf. o estudo de Hutcheon, L. (2000), Teoria e Politica da Ironia. Traduçâo de Julio Jeha. Belo Horizonte, Editora UFMG; Xavier, L. G. (2007), O discurso da ironia. Lisboa, Novo Imbondeiro.

2 Cf. definição de paródia em Sant’Anna, A. R. (1985), Parodia, paráfrase \& cia. 2. ed. São Paulo, Ática; Hutcheon, L. (1989), Uma teoria da paródia. Lisboa, Edições 70.

3 Carvalho, M. ('2004), Fantasia para dois coronéis e uma piscina. Lisboa, Caminho. Em 2004, este romance obteve o Prémio de Novelística do Pen Clube Português, patrocinado pelo Instituto Português do Livro e das Bibliotecas.

4 O termo é usado por J. Kristeva ao tratar da Intertextualidade. Cf. (1974ª), Introdução à semanálise. São Paulo, Perspectiva: 64.

5 Carvalho, M., (2003), "Mário de Carvalho: crónica do aturdimento”. JL-Jornal de Letras, Artes e Ideias 864, 12/11: 12. Entrevista de Maria João Martins. Vide também os vários versos e trechos de música inseridos no romance, 21, 48, 54, 131, 132, 218.

6 Vide Fantasia para dois coronéis e uma piscina, 34. 
Assim declara o narrador: “(... ) nós cada vez o ouvimos mais sumido, vamo-nos afastando, desliza Portugal (...) com vagar” (34). Pode-se depreender dessa passagem a noçáo de criaçáo literária como um afastamento do real, e de imaginação como elemento que propicia uma visão abrangente, englobadora das diversas realidades. Narrador e leitor cessam de ouvir os sons próximos, concretos e reais, para "voarem sobre Portugal". É a partir daí que, finalmente, dotados de todos os elementos que controlam, porque voam sobre eles, partem em uma espécie de "odisseia" da imaginação, num modelar Renault Quatro, o carro mais comum dos portugueses na década de sessenta. Neste sentido, o tema da "viagem" nesta obra literária é concebido numa dupla acepçáo: a primeira metafórica, como uma forma imagética de mencionar as coordenadas da criação; a segunda como suporte estruturante, intradiegético, do texto. De fato, é a estruturação da narrativa em vários patamares, o entrecruzamento destes planos narrativos e a simultaneidade dramática que permitem essa dinâmica cinematográfica, sempre guiada por "viajantes do vocabulário, da semântica e da real fantasia" (19).

Há preocupações com certos aspectos da criação literária que são, em Mário de Carvalho, centrais e aludidos com insistência. Quando o autor-narrador trata da composição narrativa, por exemplo, indica-nos o objetivo do romance, que "propóe-se a narrar" (34). Essa ação de narrar demandaria "o seu tempo e os seus tempos" (34), o que significa dizer que há um tempo específico para a concepção da obra de arte e os tempos da ação que compóem a narrativa, cuja multiplicidade vincula-se a própria estrutura do romance.7 Segundo D’Onofrio, o romance "é constituído por um complexo de valores temporais, em que se implicam o tempo do narrador, o tempo do relato e o tempo do leitor". ${ }^{8}$ Assim, um dos elementos fundamentais da narrativa é, sobretudo, a composição (e a manipulação) do tempo, um fator que permite um caráter demiúrgico assumido pelo autor. ${ }^{9}$ Entretanto, não se pode desprezar a importância do narrador como condutor da trama narrativa e, certamente, do tempo. Ilustra esta questão de forma modelar o romance Era bom que trocássemos umas ideias sobre o

7 Uma das características que distinguiria o romance do conto é a variedade do tempo. Cf. Moisés, M. ('1973), A criação literária: introdução à Problemática da Literatura. São Paulo, Melhoramentos: 195-226.

8 D’Onofrio, S. (1978), Poema e Narrativa: estruturas. São Paulo: Duas Cidades: 73.

9 Cf. Moisés 1973: 196. 
assunto, ${ }^{10}$ de Mário de Carvalho, no qual o autor-narrador coloca-se como um verdadeiro Criador, que se "beneficiando do tempo narrativo" (105), detém uma visão global sobre o tema, sempre "à mão do autor totalitário" (94). É por isso que declara: "Deslizo cá do meu Olimpo e instalo-me por ali, naquela sala pelintra, talvez junto ao canto superior esquerdo, encostado ao tecto, do lado da empena, que é sítio azado para tudo ver, pese embora a mancha da humildade" (114). Para se obter uma visão totalizadora da narrativa e manter um controle sobre os fatos narrados é imprescindível convocar um narrador heterodiegético, porque, como ele mesmo afirma, "um narrador omnisciente tem as suas vantagens. Se o narrador não fosse omnisciente náo saberia deste particular (...)" (35). Evidentemente, o tempo e o tipo de narrador escolhidos intervirăo no "pacto de verossimilhança" que deve haver entre o autor e o seu leitor. A literatura não tem, é óbvio, um compromisso com a verdade, no entanto os fatos narrados possuem uma equivalência de verdade, uma mimesis comprometida com a verossimilhança, ou com qualquer propriedade do "poder acontecer". ${ }^{11}$ Aqui ela é entendida pelo autor-narrador como um instrumento de controle da fantasia: "o que eu passo a contar agora é inacreditável. Prossigo a custo, após uma perplexa hesitação. A vida, não raro, ficciona, devaneia, absurdiza e eu hei-de conformar-me a ela, mais do que ao famoso pacto de verosimilhança outorgado com o leitor" (84). Certamente, essa é uma inversão irônica do entendimento sobre o processo de criação literária, na medida em que é a literatura que "representa" a vida; é ela que ficciona, devaneia e absurdiza.

Embora esse romance seja um texto contemporâneo, o processo de junção de elementos utilizados pelo autor não é novo, ao contrário, remonta a estratégias próprias e constantes na literatura grega; é particularmente sugestivo, pela própria reflexão que faz sobre esta estratégia, o romance de Luciano de Samósata e, numa vertente mais próxima de influência, a obra de Almeida Garrett. Em História Verdadeira, ${ }^{12}$ de Luciano, tal como ocorre em Fantasia para dois coronéis e uma piscina, percebemos uma voz narrativa

10 Carvalho, M. (52003), Era bom que trocássemos umas ideias sobre o assunto. Lisboa, Caminho. Embora este romance não faça parte do nosso corpus, pensamos ser importante ressaltar algumas questôes do âmbito da teoria literária, freqüentemente aludidas, nele, pelo autor. Sobre este assunto, vide supra

11 Cf. D’Onófrio 1978: 15. Para o autor, há dois tipos de verossimilhança: a interna e a externa. A primeira está relacionada à coerência dos elementos que estruturam a narrativa; a segunda diz respeito ao "bom senso e opinião comum". Se o texto não tiver uma verossimilhança externa, é porque ele está no campo do gênero fantástico.

12 Vide supra ... 
claramente metaficcional, que se intitula como autor e anuncia que seu texto nos seduzirá não somente porque o tema seja estranho, ou porque narrou mentiras diversas com ar de verossimilhança, mas sim por "à laia de paródia, cada passo da narrativa fazer alusão a certos poetas, prosadores e filósofos, que nos deixaram obras fantásticas e cheias de imaginação"13 (I. 2); afirma ainda que virou-se para a mentira, "mas uma mentira mais desculpável que a daqueles, porquanto numa coisa serei eu verdadeiro: ao confessar que minto" (I. 4). Aos vários autores que escreveram histórias fantásticas ou charlatanices, assegura que "serviu de guia e mestre (...) o Ulisses de Homero que impingiu aos Feaces narrativas de ventos enclausurados, de Ciclopes de um só olho, de homens que se alimentavam de homens, de animais bicéfalos e transformação dos seus companheiros em animais através de drogas" (I. 3). Nessa exortação inicial, o objetivo da viagem narrada é atribuído a vaidade humana, garante o autor: "eu, por vanglória, resolvi deixar à posteridade qualquer coisa do género, só para não ser o único a não beneficiar da faculdade de contar histórias fantásticas" (I. 4). A afirmativa garante ao leitor que o romance náo privilegia a verdade e sim o deleite, o entretenimento, embora faça consideraçóes filosóficas e estéticas. ${ }^{14}$

$\mathrm{Na}$ literatura de expressão portuguesa, dentre vários exemplos possíveis desse tipo de estratégia narrativa com a qual se pode relacionar o romance de Mário de Carvalho, destacamos a de Almeida Garrett, Viagens na minha Terra: ${ }^{15}$ o texto retoma as consideraçóes metaficcionais à maneira de Luciano, levando-as ao limite, e colocando em cena um autor-narrador irônico que, dialogando com o leitor, conduz a narrativa sempre expondo

13 Nickel, R. (1999), "Lucian's True Story: impressions of a fancy voyage”. Euphrosyne 27, 249/257: 250. Para o crítico, “é possível reconhecer os antecedentes literários mencionados por Luciano em alguns pontos. Todavia, há razóes para acreditar que Luciano não atribuía grande importância à possibilidade de identificação dos modelos literários de sua paródia pelos leitores".

14 Luciano mostra-se surpreso pelo fato de outros autores pensarem que suas "mentiras" não seriam notadas: "Em face de toda esta produção, não verberarei por aí além os seus autores, porquanto verificava que tal era entáo habitual, mesmo entre os que faziam profissão de filósofos. Uma coisa, no entanto, me espantava neles: o facto de cuidarem que as mentiras que escreviam passariam despercebidas". (I. 4)

15 Cf. Garrett, A. (1973), Viagens na minha Terra. Rio de Janeiro, Editora Três: 44. Neste romance, o narrador chega a dar uma receita de como facilmente se pode construir um romance: "Todo o drama e todo o romance precisa de: uma ou duas damas, um pai, dois ou três filhos, de dezenove a trinta anos, um criado velho, um monstro, encarregado de fazer as maldades, vários tratantes, e algumas pessoas capazes para intermédios". 
ao interlocutor as estruturas da criação literária e as várias relações textuais que o romance estabelece, ${ }^{16}$ ainda que não haja eventos fantásticos.

Assumindo uma composição semelhante a do texto de Luciano e de Garrett, a narrativa de Mário de Carvalho prioriza tanto o receptor quanto os elementos que compóem o romance, numa espécie de retomada das características da sátira menipéia que ambos os autores adotam. ${ }^{17}$ Dessa forma, o autor-narrador nos guia constantemente não só através de vários espaços portugueses, para o "bastidor da criação literária", mas também a outros textos a que recorre para compor sua narrativa. Os acontecimentos fantásticos (ou insólitos e sobrenaturais) que tomam a obra, ou a vida de Emanuel, convertem-se "em trampolim metafórico de uma crítica social". ${ }^{18}$

Já no início do romance, no episódio em que os dois coronéis discutem sobre uma ideal composição literária, há uma referência à questão da intertextualidade, quando um dos personagens pergunta ao outro de forma irônica: " - E as piscadelas de olho? Há gajos que se fartam de fazer citaçóes encapotadas só para ver se a malta dá por isso!” (16). Desprezando o fato de que todo o texto refere-se a outros textos, o coronel entende que os autores fazem citações apenas para testarem os leitores desavisados. Para o outro personagem, as referências são apenas labirintos, enigmas que se impóem ao leitor: "- Peneiras... Charadices..." (16). É evidente a ironia das afirmações, pois o romance a todo instante evoca direta ou indiretamente outros

16 Cf. uma análise mais detalhada desta questão em Pereira, E. (2003), "Viagens na minha terra: ciladas da representação". Revista do Centro de Estudos Portugueses 23 n. 32: 61-68.

17 Sobre a obra de Luciano, veja-se o estudo de Brandão, J. L. (2001), A poética do Hipocentauro: Literatura, sociedade e discurso ficcional em Luciano de Samósata. Belo Horizonte, Editora UFMG. Cf. também Bakthin, M. (1981), Problemas da poética de Dostoievski. Tradução de Paulo Bezerra. Rio de Janeiro, Ed. Forense-Universitária: 97-103. O autor elenca quatorze características da tradição da sátira menipéia, dentre as quais salientamos as seguintes: o aumento do peso específico do elemento cômico, embora esse peso seja flexível nas diversas obras; total liberdade de invenção temática e filosófica; a fantasia não serve à materialização da verdade, mas à busca, à provocação e principalmente à experimentação dessa verdade. Por isso os heróis sobem aos céus, erram por países fantásticos. O fantástico assume caráter de aventura. O conteúdo da menipéia é a aventura da idéia ou da verdade no mundo; combinação orgânica do fantástico livre e do simbolismo e, às vezes, do elemento místico-religioso com o naturalismo de submundo extremado e grosseiro (do nosso ponto de vista). As aventuras na terra ocorrem nas grandes estradas, nos bordéis, nos covis de ladrốes, nas tabernas, nas feiras, prisôes, orgias eróticas dos cultos secretos, etc. Aqui a idéia não teme o ambiente do submundo nem a lama da vida; uso do Fantástico experimental: observação feita de um ângulo de visão inusitado (do céu, por exemplo); a existência dos gêneros intercalados.

18 Schwartz, J. (1981), Murilo Rubião: A poética do Uroboro. São Paulo, Editora Ática: 77 
textos; entretanto, há aqui uma menção ao leitor que é digna de nota: é ele quem deverá articular as diversas citaçóes "encapotadas" que compóem o romance, determinando seus sentidos.

Das várias formas que o autor utiliza para referir outros textos, chamamos a atençáo para o recurso usado pelo tio de Emanuel, que se intromete no enredo para pedir ao narrador que proteja o sobrinho (93). Ele assume usar um expediente intertextual de forma explícita, cuja estratégia é a indicação dos mitos que retoma: "De cada vez, sou sempre forçado a calcar a estrada macerada de pedras da fábula. A figura de Sísifo também serve, mas eu nunca desafiei os deuses, nem cometi as tropelias do outro" (89). Dito de outra forma, o personagem utiliza a figura do mito, porém o adéqua a história, suprimindo elementos que pensa serem desnecessários.

É habitual no romance, também, a tática intertextual que explicita os textos literários a que se recorreu para compor determinada cena. Esse é o caso da citação direta de um episódio do Satyricon, de Petrónio. ${ }^{19}$ Vejamos:

O coronel nunca tinha lido Petrónio, porque o romano nunca se ocupou de coisas militares, e naquele instante em que contemplava a grandeza quase infinita de seus domínios náo podia saber que um tal Trimalquião já tinha procedido a um raciocínio aparentado, mas na horizontal, à uma, por se encontrar deitado, à outra, por considerar apenas o caminho terrestre entre Roma e África. (125).

A Cena Trimalchionis, protagonizada por Trimalquião, é um episódio central do romance de Petrônio, que evidencia os excessos de um "novo rico". Isto significa que os pensamentos do coronel o aproximam do personagem da Cena, já que pensava ser proprietário de um espaço que ia "até aos confins do Universo" (125), idéia que anteriormente passara pela cabeça de Trimalquião ${ }^{20}$. Ao enumerar aos convivas suas múltiplas riquezas, o anfitriâo da Cena admite ter o desejo de possuir terras suficientes para unir a Sicília à África:

19 Usamos a tradução de Bianchet, S. B. (2004), Petrônio. Satyricon. Edição bilíngüe. Belo Horizonte, Crisálida.

20 É interessante ressaltar o princípio da "cronologia relativa” que Mário de Carvalho considera um fator obrigatório na disciplina criativa: "A grande diferença é que, se tivesse calhado, o coronel poderia saber alguma coisa sobre Trimalquião, mas Trimalquião nunca poderia sequer imaginar o coronel ...” (125). 
Graças aos Deuses, eu não compro nada, mas tudo isso que agora dá água na boca de vocês vem de uma propriedade minha que eu ainda não conheci. Dizem que é vizinha à de Tarracina e à de Tarento. Agora eu quero unir a Sicília a minhas pequenas propriedades, para que, quando eu tiver vontade de ir à África, navegue pelos limites de minha propriedade. $(48,2-3)$.

Para além do diálogo intertextual, as demonstraçóes excessivas de posses e de poder dos personagens, sobretudo de Trimalquiáo, indicam uma certa falta de refinamento e os exageros de um 'novo rico', que se deslumbra com a posição financeira agora assumida.

No romance Era bom que trocássemos umas ideias sobre o assunto, o narrador, do mesmo modo, indica como podem ocorrer as relaçóes entre os textos. Por meio de um personagem que se encontra com o tio, um professor de grego, o autor demonstra outras formas de intertextualidade: é que o jovem, mesmo não tendo lido as obras, as menciona por meio da leitura de enciclopédias, dicionários ou revistas.

O fulano é engenheiro de sistemas, mas, este, garanto que nunca leu um único romance na vida! Tinha decorado aquelas frases de qualquer álbum, ou enciclopédia, e estava ali, no Gambrinus, a debitá-las, em voz de papo, para toda a gente ouvir. E eu, que li tudo, e reli, calado que nem um rato. (...) Se lhe tivesse dado para o Tucídides, que eu tenho anotado parágrafo a parágrafo, o resultado era o mesmo: ele a brilhar, e eu a engolir em seco. (156)

O que se pode depreender do episódio é que, na verdade, há dois tipos de atitude na aquisição de fontes, que Mário de Carvalho distingue com argúcia: uma precisa, resultante de uma leitura séria, aprofundada, específica (ler, sublinhar, anotar), e outra superficial, de acaso, que permite "fazer figura", mas não tem solidez (157). Importa-nos esta questão, pois, como Jenny, ${ }^{21}$ entendemos que a intertextualidade tem implicações com o "funcionamento" da literatura, ou seja, de forma direta ou indireta um

21 Jenny, L. (1979), "A estratégia da forma”. Poétique. Revista de teoria e análise literárias. Traduçấo de Clara C. Rocha. Coimbra: Almedina, 05/49: 7. 
texto sempre se relaciona com outro texto através da paródia, da imitação, da alusão, da citação ou mesmo da crítica. ${ }^{22}$ Explica-nos Otte ${ }^{23}$ que:

O fragmento em si, implantado com uma aparente arbitrariedade no novo con/texto, o interrompe, provocando um "choque" de distanciamento devido à sua singularidade. No entanto, é o próprio estranhamento que impele o leitor quanto o historiador à procura do parentesco escondido na 'bagagem' do fragmento, ou seja, à descoberta da verdadeira proximidade. (OTTE 1996: 218)

Embora algumas citaçóes do romance ou referências a outros textos possam parecer inseridas de forma aleatória, a verdade é que provocam um estranhamento inicial no leitor, e é esse mesmo estranhamento (e reconhecimento) que proporciona pistas para a compreensão das relaçôes entre os textos e, é claro, da própria obra. Todas estas estratégias de intertextualidade que mencionamos são manipuladas por Mário de Carvalho em Fantasia para dois coronéis e uma piscina. Assim, fazemos nossa a definição de romance grego de Brandáo para nomear o romance de Mário de Carvalho: "o romance é escrita desatada e enciclopédia de gêneros". ${ }^{24}$

\section{Os distintos componentes de uma obra literária}

Em relação às reflexóes metaficcionais ${ }^{25}$ que perpassam todo o romance Fantasia para dois coronéis e uma piscina, chamamos a atenção para a primeira discussão, com caráter introdutório, sobre literatura, que vem à tona através dos coronéis Bernardes e Lencastre, num debate sobre a estrutura do romance que a esposa de Bernardes lia: O Apicultor e o Bidão de Mel. Passemos às consideraçóes literárias que fazem os personagens. Para o Coronel Bernardes, aquela narrativa era:

22 Cf. a crítica que o autor faz a obra de Paulo Coelho, 66.

23 Otte, G. (1996), "Rememoração e citação em Walter Benjamin”. Revista de Estudos de Literatura 4. Belo Horizonte, Centro de Estudos Literários (CEL), Faculdade de Letras da UFMG, 211/223: 218.

24 Brandão 2005: 216. Grifo do autor.

25 Para uma análise da metalinguagem, veja-se o texto de Perrone-Moisés, L. (1979), "A intertextualidade crítica". Poétique. Revista de teoria e análise literárias. Tradução de Clara C. Rocha. Coimbra, Almedina: 209-230. 
(...) perdas de tempo, deambulaçôes, opinióes, descrições, filosofias, desarrumação... um bocejo, pá. Eu cá para mim, um livro deve apressar-se para o evento, começar logo a meio da coisa e eliminar os desvios e as imaginações que só servem para encher. Um homem com pescoço de cavalo, por exemplo (...) (15-16)

Retomando as consideraçôes da Arte Poética de Horácio ${ }^{26}$ quase na íntegra, o personagem, em tom irônico, critica exatamente as características do texto do qual faz parte, que é composto justamente por desvios, deambulaçôes, descriçôes, desarrumação e opiniōes diversas. Por meio da descrição de um ser híbrido, Horácio (1-37) defende a idéia de que a verossimilhança deve ser buscada tanto pelo pintor quanto pelo poeta. Por isso, recrimina aqueles que náo atendem ao princípio da unidade e da simplicidade do poema (23), comparando as digressóes em um texto a um "remendo purpúreo" costurado a um pano diferente, que formará um todo sem harmonia. Embora os personagens do romance defendam uma estratégia narrativa que se apresse para o evento, para a ação, esta tática não será seguida pelo autor do romance do qual os coronéis são protagonistas; ao contrário, o texto caracteriza-se pela falta de coesão e de simplicidade.

Seguindo a mesma linha de preferência do amigo, o coronel Lencastre também recorre a uma teorização antiga, agora a da Poética de Aristóteles, para definir o que seria uma estrutura narrativa adequada. Apontando para os componentes do texto literário (como a ação, os personagens, os pensamentos, o ritmo $)^{27}$ e sua hierarquia, assim se manifesta o personagem:

26 Cf. Horácio, Arte Poética 1-37: "Se um pintor quisesse juntar a uma cabeça humana pescoço de cavalo e a membros de animais de toda a ordem aplicar plumas variegadas, de forma que terminasse em torpe e negro peixe a mulher de bela face, conteríeis vós o riso, ó meus amigos, se a ver tal espetáculo vos levassem? (...) Geralmente a princípios solenes e onde se prometem grandes coisas, para obter mais efeito, qualquer remendo purpúreo se lhes cose (...) Em suma: faz tudo o que quiseres, contando que o faças com simplicidade e unidade".

27 Sobre a definiçẫo de tragédia, das partes e dos elementos essenciais, Aristóteles afirma que o elemento mais importante da tragédia é "a trama dos fatos (...) Sem ação não poderia haver tragédia", Poética 1450 a 16-23. A imitação de uma ação se "executa mediante personagens e que diversamente se apresentam (...)", 1450 a 35. Já o pensamento “é aquilo em que a pessoa demonstra que algo é ou não é, ou enuncia uma sentença geral”, 1450 b 4. A elocução é definida como "o enunciado dos pensamentos por meio das palavras", 1450 b 12, 1456 a, 1456 b e 1457 b. A "toada” ou melopéia é considerada pelo autor como “o principal ornamento", 1450 b 15. Em relação ao "espetáculo cénico, decerto é o mais emocionante, mas também o menos artístico e menos próprio da poesia. (...) a realização 
(...) o mais importante é o entrecho, a acção. Depois vêm as personagens e respectivo desenho moral. A seguir, o pensamento, os conceitos. Mas também a maneira como está escrito, o português, se é bom ou mau. Há ainda a toada, o ritmo, que é importante. Finalmente, o modo como os acontecimentos são postos diante dos nossos olhos, a ... como hei-de dizer? A espectacularidade da coisa (...). (16)

Essas consideraçóes do personagem (estipuladas através de uma ordem de prioridades) fazem parte de uma espécie de jogo irônico realizado pelo autor ao longo do texto, pois o coronel não lia um romance há trinta anos (16), nem seria versado em teoria literária; logo náo estaria apto a tratar do assunto. Praticamente todas as características assinaladas e elogiadas pelos personagens serão contrariadas pelo autor ao longo da narrativa. De acordo com Compagnon, "a atitude dos literatos diante da teoria lembra a doutrina da dupla vertente na teologia católica. Para seus adeptos, a teoria é ao mesmo tempo objeto de fé e uma apostasia: crê-se nela, mas não inteiramente". ${ }^{28}$ Essa parece ser a postura do autor de Fantasia para dois coronéis e uma piscina.

\section{2. $\mathrm{O}$ enredo}

Ao tratar do enredo, o Coronel Bernardes defende a exclusão do acessório, dos desvios e da imaginação (15), em nome de um fio narrativo claro e coeso: "Deve dizer-se logo o que tem de ser dito, e pôr os pormenores de lado, não achas?" (16), pergunta ao amigo. Deste modo, defende um texto que narre os fatos considerados prioritários, omitindo os elementos

de um bom espetáculo mais depende do cenógrafo que do poeta”, 1450 b 16. Sobre as relaçóes entre os fatos no enredo afirma o seguinte: "Homero, assim como se distingue em tudo o mais, também parece ter visto bem, fosse por arte ou por engenho natural, pois, ao compor a Odisseia, não poetou todos os sucessos da vida de Ulisses (...) mas compôs em torno de uma ação una a Odisseia, _ una, no sentido que damos a esta palavra, e de modo semelhante a Ilíada. (...) Por conseguinte, tal como é necessário que nas demais artes miméticas una seja a imitação, quando o seja de um objeto uno, assim também o mito, porque é imitação de açóes, deve imitar as que sejam unas e completas, e todos os acontecimentos se devem suceder em conexão tal que, uma vez suprimido ou deslocado um deles, também se confunda ou mude a ordem do todo. Pois não faz parte de um todo, o que, quer seja quer não seja, não altera esse todo", 1451 a 22,1451 a 29.

28 Cf. Compagnon, A. (2001) O demônio da teoria: Literatura e sendo comum. Belo Horizonte, Editora UFMG: 258. 
indesejáveis (os desvios e a imaginação). Também o narrador de Era bom que trocássemos umas idéias sobre o assunto ilustra o que seria "o indesejável acessório" em uma narrativa, ou seja, o que não está intimamente relacionado ao enredo: "(...) mas, francamente, acho que estas personagens não merecem que se faça o jeito e o leitor há-se ser poupado àquilo de que não precisa, porque, tal como eu, se está nas tintas para as emblemáticas comerciais" (82). Para Lencastre, é necessária uma coesão entre os elementos do texto, de forma que ao se retirar algum componente, o conjunto não resista: “- Pois para mim, os factos devem estar numa tal relaçáo que, suprimido ou deslocado um deles, também o conjunto se transforme ou confunda. $\mathrm{O}$ que se pode acrescentar ou tirar sem conseqüências, não faz parte do todo" (16), ou ainda, em decorrência "de linear e límpida causalidade" provêm resultados de "carácter imediato e muito prático" (43). No elogio da unidade de ação e da supressão dos desvios, evoca-se a máxima latina in medias res ("no meio dos acontecimentos"), utilizada por Horácio em sua Arte Poética (148), como a estratégia adequada para iniciar uma narrativa. Esta deve assumir como ponto de partida um momento adiantado do desenvolvimento da ação, e não os fatos iniciais do enredo. Por meio da analepse, os eventos excluídos do princípio da ação serão recuperados numa fase posterior do romance. ${ }^{29}$ No caso da epopéia grega, a primeira a utilizar esta tática na literatura ocidental, embora a disposição dos fatos não obedeça a uma ordem linear, o enredo não perde em verossimilhança; ao contrário, este recurso cria uma dinâmica narrativa extremamente ágil, tanto que a analepse (ou o flash-back) é hoje amplamente explorada pelo cinema como uma tática que permite uma agilidade maior a narrativa fílmica. Este recurso é valorizado tanto no em Fantasia para dois coronéis e uma piscina, quanto em Era bom que trocássemos umas idéias sobre o assunto. No primeiro romance, a ação inicia já com os coronéis morando no campo e em torno da piscina (12-16); os fatos anteriores só serão retomados posteriormente; no entanto, a cena inicial dos coronéis discutindo sobre literatura será recuperada quase na íntegra ao final do romance (207). Em Era bom, o autor-narrador defende abertamente a narrativa que inicia in medias res e o flash-back ao afirmar que: "Os cineastas - deslembrados de Homero ou Camóes - estão candidamente convencidos de que foi o cinema que inventou a analepse, a que chamam flash-back. E até há alguns que manifestam animadversão contra

29 Cf. Il. 1.9 sqq. e Od. 1.11 sqq. Camôes, em Os Lusíadas, segue o modelo épico tradicional, começando a narrativa sobre a viagem de Vasco da Gama in medias res. Cf. 1. 19 sqq. "Já no largo Oceano navegavam, As inquietas ondas apartando (...)". 
os flash-backs (...) E vem a tal analepse para contar o que se passou momentos antes (...)" (21). Seguindo esta estratégia, o cronovelema é estruturado como uma espécie de "filme em forma de romance, em que a narrativa é apresentada numa sucessão de planos, sugerindo-se a movimentação de câmara, como se os vários espaços, tempos e personagens que desfilam nesta Fantasia estivessem a ser projectados num ecrã". ${ }^{30}$

Para eliminarem-se desvios e deambulações desnecessárias, a tragédia conta com um componente importante, o Prólogo. De acordo com Aristóteles (Poética 1452b 18), "Prólogo é uma parte completa da tragédia, que precede a entrada do côro", e que executa um papel coordenador, que antecipa e ordena a narrativa. Este tipo de introdução, que também antecede alguns episódios de Fantasia para dois coronéis e uma piscina, que aqui se faz ouvir pela voz do narrador, e não dos atores como ocorre na tragédia, é utilizado pelo autor (na esteira dos escritores clássicos) para se dirigir aos leitores a fim de ironizar algumas situaçóes, pedir benevolência ao "experiente leitor", ou fazer consideraçóes sobre a composição do próprio romance. ${ }^{31}$ Dessa forma, o "prólogo" desta Fantasia nem sempre cumpre a função de antecipar os eventos do enredo, como afirma o próprio narrador: "Algo ficámos já a saber do que importa, mas náo tudo" (34); essa falta de visão geral sobre a ação, muito explorada na tragédia grega do séc. v. a. C. como um fator de suspense, contraria o ensinamento aristotélico, na medida em que estimula as digressóes do narrador. Temendo que a previsibilidade das ações do enredo (ditadas por um 'Prólogo') tornasse os leitores "desatentos”, já que as conheceriam previamente, o autor-narrador lança mão do elemento surpresa, que pode advir de uma quebra na esperada coesão da estrutura da narrativa. Essa tática náo corresponde aos ensinamentos de Aristóteles, embora fosse comum no teatro grego.

O procedimento de anular a ilusão cênica é retomado neste romance em vários pontos da narrativa, mas uma das passagens mais sugestivas é a que transcrevemos abaixo, quando o narrador discute com o leitor sua estratégia narrativa:

Tentaçáo enorme, ó experiente leitor, de parar aqui e mudar de foco. Fazer actuar o efeito de deferimento. Emanuel estarrecido, sem pinga de sangue, por onde andarão os cães horrendos? E mudar de capítulo,

30 Mendes, A. M. G. (2005), "Trimalquião, os coronéis e a piscina: retrato impiedoso de um país em crise". Ágora. Estudos Clássicos em Debate. Aveiro 7, 129/150: 229-130.

31 Às vezes, a chave para a antecipação dos fatos é um breve: "Pois assim se resume" (36). 
passar para São Jorge do Alardo, ou Lisboa, e o leitor ansioso, a procurar nas páginas mais adiante, a querer saber se Emanuel foi estraçalhado pelos cães, ou se lhe apareceu, pendurada ao alto, aquela figura divina e providencial que costuma desviar-lhe os caminhos. Mas eu não sou um escriba manipulador, especioso em ganchos, chif-hangings e outros artifícios para prender a atenção do narratário. Vozes se levantarão contra os meus processos tão cristalinos de limpidez e boa intenção. Eu sou franco, náo há arcas encouradas, digo logo tudo. (60-61)

A ironia da afirmativa reside no contraste entre as características defendidas pelo narrador e como de fato ele conduz a narrativa. Na verdade, ele é realmente um manipulador nada cristalino e muito mal intencionado, que renuncia a todas as convençóes para compor um texto que, para além das açóes, centra-se em sua própria constituição fragmentada. Essas intromissóes do narrador no enredo e as conversas com o leitor e com os personagens nos remetem às teorizaçóes de Adorno (1983) sobre a posiçáo do narrador no romance contemporâneo. Segundo o teórico, o narrador investe contra um componente essencial "na sua relação com o leitor: a distância estética. Esta era inamovível no romance tradicional. Agora ela varia como as posiçóes da câmara no cinema: ora o leitor é deixado de fora, ora guiado (...) até o palco, para trás dos bastidores, para a casa das máquinas". ${ }^{32}$

Com um "Posso?"33 (80), um outro personagem, tio de Emanuel, interrompe a história sobre os coronéis, pois, segundo ele, essa era uma ótima ocasiáo para entrar na narrativa e deixar uma mensagem para o parente, um andarilho difícil de ser encontrado (80). Havia pensado em colocar um anúncio no jornal, assegura, mas esta era uma alternativa cara e da qual não se podia ter garantias de sucesso. Este é um exemplo dessa mesma quebra de ilusão, que parece ser do gosto de uma certa narrativa contemporânea: "De resto, esta é uma narrativa contemporânea - acho eu - que desconfia dos acasos e das causalidades manipuladas...” (82). Através da afirmativa podemos inferir que no romance contemporâneo não há coincidências; os

32 Adorno, T. W. ( $\left.{ }^{2} 1983\right)$, "Posição do narrador no romance contemporâneo". In: Benjamin, Honkheimer, Adorno, Habermas. Tradução de José L. Grünnewald et al. São Paulo, Abril Cultural, 269/273: 272.

33 Esta é uma estratégia próxima da chamada 'quebra da ilusão cênica' - ou seja, de fazer saltar uma personagem da cena, ou retirá-la da intriga, e pô-la a dialogar diretamente com o público - que é muito vulgar na comédia grega. Cf. e.g. Aristófanes, Acarnenses 628 sq., Nuvens 535, 1115 sq., 1121, Paz 629, Aves 1101, 1114. 
eventos não são dispostos gratuitamente no texto, ao contrário, correspondem a um tipo de construção textual que se volta sobre si mesma.

Por meio desses diálogos com o narratário, da intercalação de narrativas variadas e do diálogo irônico com o leitor, o narrador destrói a tranqüilidade contemplativa do leitor diante do que lê, como se pode perceber através do seguinte comentário do autor-narrador: "Um dia, leitor, hei-de contar as ânsias e os tormentos com que se vai martelando esta artesania da escrita, em que ainda sobrevive a mão do caldeireiro ou, talvez do fazedor de autômatos (...)" (216). O que esse autor-narrador faz é desnudar aos olhos do leitor a forma como se constrói um texto ficcional, que é realizado sempre por meio de uma labuta constante, não necessariamente bem paga (216).

\section{A composição do personagem}

Um enredo coeso e regular exige do autor uma cuidadosa criação dos personagens e de seus respectivos desenhos morais, pois eles são portadores das idéias que sustentam a narrativa. Aristóteles (Poética 1448b 4) foi o primeiro a teorizar sobre o personagem ao assegurar que "imitar é congênito ao homem (...) e os homens se comprazem no imitado". Tanto nos textos narrativos quanto nos teatrais, o personagem é o componente essencial através do qual o enredo se desenvolve, ou seja, "as personagens constituem os suportes vivos da ação e os veículos das idéias que povoam uma narrativa”. ${ }^{34}$ Não raro alguns personagens, por causa de suas características ideológicas, morais ou mesmo físicas, podem ser considerados como modelo de determinados comportamentos. Assim, a criação do personagem no romance pode ocorrer pela generalização dos traços, como a que acontece com Emanuel Elói: "É daquelas figuras que inspira simpatia e confiança a um primeiro olhar, mesmo de longe" (14). Ou mesmo pode haver um desmontar de uma identidade pessoal para se obter um modelo; este é o caso da descrição do Coronel Bernardes, que é, afinal, um exemplo da classe a que pertence: "Como é sabido, os militares oficiais superiores são, entre os cidadãos que compóem uma vasta classe média, os mais ampla e diversificadamente relacionados." (64). A construção da piscina é o meio pelo qual a articulação entre as diferentes personagens ocorrerá, pois, através dela, "havia uma universal vontade de ajudar", "reatou-se a cadeia de solidariedade, numa teia de malhas estreitas que cobria e apertava Portugal

34 D’Onofrio 1978: 62. 
de sul a norte"35 (65). É importante mencionar a identificação dos tipos humanos dispostos a auxiliar o coronel na empreitada: "Há uma multidão de capitáes, majores, brigadeiros, engenheiros, médicos, professores, que estão ávidos por ajudar" (64). É como se fosse o país inteiro a se movimentar para executar essa tarefa, já que a piscina tem a mesma forma de Portugal. É neste contexto que um importante personagem, Emanuel, surgirá: ele é "vedor de águas", um técnico que o major Linhares Beira indica para trabalhar para o coronel Bernardes (66).

É pelo nome 'falante' que inicialmente se define esse personagem. O próprio Emanuel explica a escolha de seu nome:

- O meu pai quis dar-me um nome benigno e abençoado e fez uma lista de que constavam os seguintes: 'Eloim, Adonai, Sadai, Soter, Emanuel, Sabahot, Tetragrammaron, Alpha e Omega, Principium et Finis, Hagios, Ischiros, Otheos, Athanatos, Agla, Jehova, Homonsion, Ya, Iesus Christós, Messias, Elva, Elrei...' Mas o empregado do Registro civil só aceitou Emanuel. (67)

No Evangelho de Mateus, o nome Emanuel é mencionado para designar o filho de Deus que nasceria: "Tudo isto aconteceu para que se cumprisse o que foi dito da parte do Senhor, pelo profeta, que diz: Eis que a virgem conceberá e dará à luz um filho, e chamá-lo-ão pelo nome de Emanuel, que traduzido é: Deus conosco". ${ }^{36} \mathrm{O}$ retrato que se pinta de Emanuel relaciona-se, certamente, a algumas características do próprio Cristo, que o ideário cristáo consagrou como o dom da caridade, a bondade e a quem atribuiu o

35 No romance Era bom que trocássemos umas idéias sobre o assunto, o autor tece diversas consideraçóes sobre os personagens. As relaçôes entre os personagens são explicadas pelo narrador: "Eduarda tem um destino a cumprir e eu arranjarei maneira de a integrar na história" (59). Por isso, o narrador articula as histórias dos personagens: "E assim se estabeleceu o contacto entre Eduarda Galvão e Jorge Carreira Matos, aprestando-se uma ligação nesta história que já nela tardava" (67); e constrói o retrato psicológico dos mesmos, embora afirme não querer entrar em detalhes: "Eu não queria entrar muito em pormenores psicológicos, porque tenho pressa, e prometi não aprofundar em excesso esta figura, mas talvez não seja despiciendo sublinhar aquilo que já está percebido" (61). Em relação às atitudes das personagens, afirma que é necessário que haja alguma sobriedade em sua descrição para que não seja muito extensa: "um escritor estilista dedicaria umas boas três páginas a descrevê-la, com gestos, saltos, risinhos, urros e queda de unidades" (85).

36 Biblia Sagrada, Mateus. 1, 22. Cf. também Isaías. 7,14: "Portanto, o mesmo Senhor vos dará um sinal: eis que uma virgem conceberá, e dará à luz um filho, e será o seu nome Emanuel". 
hábito de andar pelas cidades pregando seus ensinamentos e curando doentes: "percorria Jesus toda a Galiléia, ensinando nas suas sinagogas (...)". ${ }^{77}$ Emanuel também é descrito como um "moço jeitoso que anda sempre bem disposto. Ele é andarilho, gosta de bem fazer, meteu-se pelo país numa carrinha Renault Quatro" (81); durante as viagens, sempre se preocupava com os outros, como quando pára a viagem para ajudar o Apicultor de mel (14); ou quando cura um marinheiro do navio Telos que sofria de escorbuto (116). Não é por acaso que o caráter e as atitudes do personagem estão em consonância com o próprio nome: "chama-se Emanuel Elói, ${ }^{38}$ é uma bondade de moço, trotamundos, e tem algum jeito e muita paciência para os seus conterrâneos" (14); afinal, estas sáo as atitudes esperadas de um "Deus conosco". Agindo de forma abnegada para com o próximo, Emanuel demonstra um certo desapego pelos bens materiais, que se traduz em seu próprio aspecto físico (14). O personagem parece seguir os ensinamentos de Cristo, para que não se ajunte "tesouros na terra, onde a traça e a ferrugem tudo consomem, e onde os ladróes minam e roubam", ${ }^{39}$ pois o único bem material que tem é seu velho Renault Quatro, com o qual viaja tanto por Portugal quanto por lugares fantásticos. Os termos usados para qualificá-lo (como bondade, paciência, benignidade, piedade) estão no mesmo campo de significado com o qual se qualificava Cristo, tanto que Maria das Dores sentia que havia algo diferente no rapaz: "Haver mais bonitos moços, há, mas este tem o seu quê, palavra de honra" (70). Neste sentido, o autor atentou para os ensinamentos aristotélicos, segundo os quais deve haver uma certa coerência na composição dos personagens; assim, o caráter, as idéias e as atitudes do jovem estão de acordo com sua aparência física, como fica evidente na seguinte descrição: "alto, desengonçado, com um cabelo espigado, às farripas, e uma cara agaitada, de traquinice benigna, não ficava mal na paisagem" (66). Talvez seja por causa destas características que Emanuel fosse "um eleito muito especial do destino e favorito de uma caterva de deuses que seria fastidioso enumerar" (45).

Como recurso metaficcional, o autor-narrador convoca Maria das Dores e Maria José, as esposas dos coronéis, para uma conversa "em cena" (175-187) sobre os papéis desempenhados por estas mulheres, numa espécie de apreciação crítica sobre a estrutura e agentes da ficção contemporânea.

\footnotetext{
37 Mateus. 4, 23. Veja-se, também, as andanças de Jesus no Evangelho de São Marcos.

38 Marcos. 15, 34: “(...) Jesus exclamou com grande voz dizendo: Eloí, Elóí (...) que traduzido é: Deus meu, Deus meu (...)”

39 Mateus. 6, 19.
} 
É principalmente através deste diálogo que passamos a conhecer alguns pormenores das personagens.

A esposa de Lencastre não possui um papel relevante no enredo, embora se relacione com os outros personagens da intriga; à Maria José Lencastre, o autor-narrador dispensa, mesmo assim, alguma atenção, chamando-a para uma conversa. A intenção do autor é que a personagem não ficasse "tão apagada nesta história" (176); por isso dá-lhe oportunidade para que faça os comentários que achar importantes. Diante da negativa da figura em continuar o diálogo, o narrador a adverte: "não vai depois recriminar-me por lhe ter dado pouca atenção? Veja lá...” (178); esta é certamente uma inversão irônica de papéis, pois quem determina o que acontece no romance é o autor. Porém, de acordo com Lopes, "mesmo quando o autor se arroga o papel do ditador, se a obra existe (sic.) ela resiste a essa arrogância". ${ }^{40}$

$\mathrm{O}$ autor estabelece um claro contraste entre as duas mulheres. Em relação aos nomes, à Maria José é dado o nome completo, com vários sobrenomes "Campos de Sousa e Lencastre" (176); "Adoptou o nome do marido, não foi? Na altura não era obrigatório" (176). Através do nome, percebe-se que é uma mulher secundarizada e dependente do marido. Já Maria das Dores é o contrário: não diz o nome completo ao narrador, não usa sobrenomes do marido, o que lhe reforça o individualismo e autoconfiança (182). Maria José, como figura secundária e apagada que é, tem uma atitude tímida: procura não responder às perguntas que lhe faz o autor, tenta sair de cena, fala laconicamente sobre si mesma, mas alarga-se na descrição da suas relaçóes com as outras personagens, o que é a própria justificação de uma personagem secundária (175-178). Maria das Dores, ao contrário, como personagem de relevo, centra seu discurso sobre sua própria figura, justificando sua atuação e detendo-se em seus traços principais: o discurso e o adultério (182-187). De forma diferente da vizinha, Maria José nunca freqüentou um colégio como o de Odivelas (176), mas um liceu normal; formou-se no tempo certo, deu aulas, seguiu o marido, namorou às escondidas, ou seja, há uma diluição de traços e a construção de uma figura vulgar (completamente ao contrário da Maria das Dores, a começar pelos estudos no colégio de Odivelas). O contraste explícito entre as duas personagens é sublinhado por Maria José no texto que prepara o diálogo que vem a seguir entre o autor e a segunda mulher: “(...) somos de geraçóes diferentes, ela é mais nova, mais... desinibida. Usa uma linguagem que não liga muito com o meu estilo. É mandona, menina rica, está toda envaidecida por estar a fazer a tese" (177).

40 Lopes, S. R. (2003), A defesa do Atrito. Viseu, Edições Vendaval: 31-32. 
O tom da conversa com Maria das Dores é outro: a personagem, dotada de um caráter dominador e auto-suficiente, garante que náo deve nada ao narrador e pede para terminar a conversa, ao que ele responde:

Com certeza, por quem é. Até não é impossível que aconteça outra coisa. Imagine que eu a suprimo de todo desta história. Posso sempre voltar ao princípio e prescindir da Maria das Dores. Faço o Bernardes viúvo, ou celibatário, caso-o com outra, amigo-o com uma desconhecida... e duvido muito que outro autor se interesse por ela. (183)

Com esta clara alusão ao poder que detém o autor de compor, transformar, misturar, suprimir algum elemento ou personagem de seu texto, o narrador ressalta uma importante questáo para os estudos literários: a estrutura textual. Ao ser questionada pelo narrador sobre o porquê de sua "convocaçáo", a personagem, em tom de desprezo, responde que são "efeitozinhos estilosos. Farófias" (186). A respeito deste episódio, em que se discute abertamente a construçáo do texto, ressaltamos a afirmativa de Hutcheon ${ }^{41}$ de que a necessidade do romance moderno em pensar sua própria constituição evidencia o interesse de parodiar, que é essencial no gênero narrativo desde sua origem, o que demonstra tanto uma pretensão de produzir ficções quanto de admitir seu caráter fictício. ${ }^{42}$

Retornemos a atençáo para o desenho das personagens femininas no romance português que nos ocupa. Defendendo o texto que privilegie uma ação una, despida de digressóes inúteis, Lencastre ressalta a necessidade de se criar uma personagem dotada de harmonia de traços. A referência a esta característica é extremamente contraditória, pois Maria das Dores, esposa do coronel Maciel Bernardes e uma das personagens principais, representa a transgressão desta desejável harmonia: embora seja uma mulher erudita, possui uma linguagem que não se adequa ao resto do retrato; "falava (...) destemperadamente, não dissimulava, nem se esforçava por isso" (30). Apesar desta linguagem vulgar, era formada em História da Arte, e no momento elaborava uma tese de mestrado intitulada $O$ traje feminino entre os povos originários da Lusitânia Tarrogonense, que seria apresentada na Universidade de Évora (32). Além disso, havia estudado no respeitável Colégio de Odivelas, "lia livros, sabia descascar e comer pêssegos, não

41 Hutcheon, L. (1977), "Modes et formes du narcisisme littéraire”. Poétique 29: 90-106.

42 Esta mesma estratégia de colocar em cena uma crítica literária é um elemento marcante no teatro grego, na tragédia e, ainda de forma mais explícita, na comédia. 
usava talher nos aspargos e, no entanto, exprimia-se destarte. O coronel já desistira de lhe explicar que não ficava bem dizer 'não me fodam' às mulheres dos outros oficiais, a meio dum jogo de canastra" (29); assim, o desenho social de Maria das Dores é incompatível com seus outros predicados. Por isso seu nome muda também, e o marido passa a tratá-la, ironicamente, por $A$ Baronesa (23). $\mathrm{O}$ apodo, na verdade, não era elogioso, ao contrário, fora-lhe dado após a descoberta de uma traição ao marido, que agora a chamava por um apelido "carregado de um veneno esverdeado, fétido, capaz de fulminar à distância" (31). Pode ser sugestivo, entre as figuras femininas do teatro antigo com as quais podemos relacionar a Baronesa, destacar a de Fedra, personagem do Hipólito, ${ }^{43}$ de Eurípides, por causa da ousadia das figuras que transgridem o código moral da sociedade em que vivem e, também, pelo próprio discurso que ambas proferem em defesa de seus atos. Inquirida pelo narrador sobre sua maneira de falar, a própria personagem do romance tem a possibilidade de justificar seus atos, embora ironize a situação ao afirmar que não deve satisfaçóes ao autor (183), por uma estratégia semelhante, ao colocar em cena uma dupla de personagens que, além de agir com total liberdade, analisam seus próprios atos e motivaçóes. A voz da interlocutora de Fedra, a Ama, é substituída pela voz do autor-narrador que indaga Maria das Dores sobre o motivo do adultério que comete. Tanto a rhesis de Fedra como a de Maria das Dores têm como cerne o tema do adultério e a condição feminina. $\mathrm{O}$ que difere nos seus discursos é que Fedra procura se manter afastada desta "tentação vulgar na mulher" 44 , pois "como mulher, sabia-o bem, era para todos objeto de ódio" (405-407); Maria das Dores, igualmente, critica o que pensa ser uma posição machista do autor, e por extensão do mundo em que vive: "É evidente que sempre me tratou às três pancadas. Os machos absorvem toda a sua atenção. Você não percebe peva de mulheres nem quer perceber" ${ }^{\prime 35}$ (186). A personagem explica sua "tendência" ao adultério como uma "vontade de enredo, vontade de mistério, vontade de variar, vontade de encher o paiol" (185). Ou seja, a Baronesa não traía o marido porque se apaixonava por outros homens, mas simplesmente pelo gosto de colecionar, porque era "aditiva", afirma (185), o que demonstra um total desprezo pelo moralismo (e machismo) da sociedade a que pertence (185).

43 Utilizamos a tradução de Oliveira, B. S. (1997), Eurípides. Hipólito. Brasília, Editora UNB.

44 Silva 2005: 182.

45 Cf. a questão da dimensão dada à personagem em Ar. Rãs v. 1059-1062. 
Por meio de um discurso argumentativo, tal qual o dos retores clássicos e da própria Fedra, a personagem relativiza a ética habitual até o ponto em que o respeito aos sentimentos do marido passa a náo ter nenhuma importância. Neste sentido, seu comportamento imoral é coerente com a linguagem "desbragada" que utilizava, ou mais precisamente, a palavra (logos) coincide com a açáo (pragma); embora seu impulso natural (physis) não esteja de acordo com a convenção social (nomos) da sociedade em que vive. ${ }^{46}$ No que diz respeito à proporção palavra-ação, há que ter cuidado com a "teatralidade" de uma personagem: "Essas coisas, num texto, não se dizem. Mostram-se" (186-187), garante o narrador.

É importante mencionar também o tio de Emanuel, que conviveu com o Nelson Lencastre desde pequeno: ele é um personagem secundário que pede licença ao autor-narrador para entrar em cena. Seu nome não é mencionado, porque segundo ele: "o meu nome náo interessa. Sou o tio dos bigodes torcidos e do casaco de tweed, e infelizmente as minhas qualidades são habitualmente apreciadas de modo assaz superficial" (82). Parece haver a tipificaçáo de um modelo de personagem - "o tio" -, com a sua caracterização, sobretudo, exterior. Embora sua dimensão seja mais apagada que a de outros personagens, ele contribui para a definição das outras figuras mais relevantes, como por exemplo, a de Emanuel. Sobre esse personagem, que é tratado como um 'mensageiro', há aspectos a valorizar: até que ponto, por exemplo, o mensageiro é apenas uma testemunha do que relata, ou um interveniente ativo; ou que relação tem com a figura sobre a qual se pronuncia. Quando menciona Nelson, o 'tio' demonstra que teve um contato direto com o personagem, pelas referências à infância dos dois: "brinquei com o Nelson em miúdo"; "acho que sei mais dele (...)"; "ainda me recordo" (80); "nós brincávamos"; "me feri ... borbotei ... sobrevivi"; "impressionava-me" (81). Em contraste com o que sabe sobre o Nelson, do sobrinho o 'tio' pouco sabe: "não sei o número do telemóvel" (81); "não tenho forma de o contactar" (81-82); "já pensei em pôr um anúncio no jornal” (82). Parece claro que o contacto com os dois se fez em tempos diferentes e em circunstâncias distintas.

46 Aos comentários intradiegéticos, feitos pelas personagens, o autor associa a voz dos críticos externos, aqueles que para a dissonância da personagem encontram sutis razóes psicológicas; faz-se também uma curiosa conexão com estratégias cinematográficas, numa confluência de processos entre as diversas formas de mimesis (o que Aristóteles também sugere na Poética). 
É também do "mensageiro" a estratégia de abrir a narrativa imediata a outros tempos e a outros contextos (80), intervindo em momentos em que não há ação. Interessa-nos, pois, o tipo de discurso que profere e o estilo que usa, com mençóes explícitas a termos da linguagem retórica. Segundo Perelman, o objetivo da argumentação não é provar uma verdade ou chegar a uma conclusão e, sim, conseguir a adesão do interlocutor; ${ }^{47}$ é exatamente a adesão do sobrinho à sua tese que visa o discurso do tio de Emanuel. $\mathrm{Na}$ primeira referência que o personagem faz sobre a linguagem retórica que utiliza, chama a atenção para "o árduo e consabido exercício da memória" (85). Explica-nos Lausberg, que a elaboração do discurso argumentativo pressupóe cinco fases: inventio, dispositio, elocutio, memoria e pronuntiatio. ${ }^{48}$ Ainda segundo o mesmo autor, a inventio não é o próprio processo de criação, mas "como encontrar um meio da recordação: os pensamentos (...) já existem, no subconsciente do orador (...) e só precisam ser despertados por uma hábil técnica mnemónica (...)" ${ }^{49}$ A memoria consistiria da memorização do discurso, enquanto que a pronuntiatio é a própria "pronunciação de um discurso e dos gestos concomitantes". ${ }^{50} \mathrm{O}$ discurso do tio de Emanuel é extremamente misógino, afirma o narrador, e advoga a favor da "tese acerca das mulheres desencontradas" (88). Pode-se dizer que a estruturação de seu discurso argumentativo é contraditória, denuncia o narrador: primeiro, o personagem defende a "ênfase no discurso ao sobrinho", ou a memorização do mesmo (88); depois, "a premência do conteúdo dele" (88), já que o personagem garante que se pronuncia "pelos conteúdos" (87). Entretanto, seu desenho pouco nítido ou a estruturação de seu discurso de forma contraditória náo chegam a ser um problema no romance, pois o personagem é um ser de "papel", cujas posiçôes e atitudes podem se transformar a todo o momento justamente por seu caráter ficcional: aliás, ele só tem relevância na narrativa pelos discursos que profere.

Chamar à cena um personagem para discutir seu papel ou inserir um personagem que contesta o discurso dos outros é uma estratégia para mos-

47 Cf. Perelman, C. O. (1993), O Império Retórico: Retórica e Argumentação. Tradução de Fernando Trindade e Rui Alexandre Grácio. Porto, Edições Asa: 29.

48 Lausberg, H. ( $\left.{ }^{4} 1967\right)$, Elementos de Retórica Literária. Tradução e prefácio de R. M. Rosado Fernandes. Lisboa, Fundação Calouste Gulbenkian: 91. 49

49 Ibidem 1967: 91. 40. A dispositio é a "escolha e ordenação favoráveis ao partido, as quais, no discurso concreto se fazem dos pensamentos, das formulaçôes lingüísticas e das formas artísticas" (95. 46). Já a elocutio é “a expressão linguística dos pensamentos encontrados pela inventio" (115. 91).

50 Lausberg 1967: 93. 45. 
trar os artifícios ficcionais ao leitor; ao agir assim, essa literatura narcisista exige deste a mesma capacidade imaginativa utilizada no ato da criação; por isso o narrador chama o leitor de "experiente" (60): só um narratário atento e experimentado pode compreender melhor estes mecanismos da ficçáo moderna. O questionamento do narrador dá-nos conta deste dispositivo: "porque é que a vida não explica a si própria, como os romances?" (155). Este tema do "destinatário experiente" era muito comum na comédia grega. Aristófanes, por exemplo, mantém este tipo de diálogo com o público a propósito da competência criativa. Impulsionado pelo caráter competitivo das representaçóes teatrais, o poeta precisava agradar tanto ao público que o ouvia, quanto os juízes que julgariam a peça. ${ }^{51}$ Para tanto, eram comuns na parábase os apelos, elogios ou censuras dirigidos aos ouvintes, os louvores ao público ou ao próprio texto e mesmo a promessa de benefícios aos juízes. ${ }^{52}$ Assim, "por trás de toda esta variedade de reacçóes e atitudes está um único e primordial interesse: que o público acolha com benevolência o poeta e não se mostre parco em aplausos". ${ }^{33}$

Concluindo, importa ressaltar, a respeito das relaçóes entre os textos e as discussōes metaficcionais, a clara noção que tem o narrador sobre a constituição do romance, ou sobre como um texto é sempre contaminado por outro texto, da mesma forma que as palavras são contaminadas por outras. Podemos afirmar, entâo, que uma das questóes centrais tratadas pelo autor sobre a criaçáo literária é a impossibilidade de se conceber uma narrativa contemporânea totalmente autônoma, sem relação com a literatura (e a cultura) erigida ao longo da história da humanidade. Mesmo sendo autônomo e criativo, um texto moderno não pode (e não quer) negar sua relação com a tradição literária já existente.

51 Silva, M. F. S. (1987), Critica do teatro na Comédia Antiga. Coimbra, Fundação Calouste Gulbenkian: 24.

52 Dentre vários exemplos destes subterfúgios, cf. o elogio ao público "com bom gosto" em Aristófanes, Nuvens 521, 527; promessas de regalias aos juízes e de castigo se o prêmio não fosse concedido, Nuvens 1115-1121, Aves 1101-1114; auto-elogio, Acarnenses 628 sqq., Paz 734 sqq.

53 Silva 1987: 27. 


\title{
Trimalquiáo, os coronéis e a piscina: retrato impiedoso de um país em crise
}

\author{
António Manuel Gonçalves Mendes \\ Universidade de Aveiro
}


(Página deixada propositadamente em branco) 
Com a publicação, em Novembro de 2003, do romance Fantasia para dois coronéis e uma piscina ${ }^{1}$, que tem merecido o melhor acolhimento por parte da crítica e do público ${ }^{2}$, Mário de Carvalho dá continuidade a "um opus dos mais consistentes da contemporaneidade" ${ }^{3}$, recuperando alguns tópicos e técnicas já revelados em obras anteriores, mas conferindo-lhe novidade, a começar pela designaçáo deste seu romance como um "cronovelema" (34), que o autor define como "uma narrativa que participa de vários géneros de escrita - novela, crónica, cinema e até poesia" ${ }^{\text {". Para }}$ além disso, este livro apresenta-se como um filme em forma de romance, em que a narrativa é apresentada numa sucessão de planos, sugerindo-se a movimentação de câmara, como se os vários espaços, tempos e personagens que desfilam nesta Fantasia estivessem a ser projectados num ecrã. Neste sentido, a escolha do título é tudo menos ingénua: por um lado, o romance vai sendo construído à imagem das composiçóes ou improvisos, mais ou menos livres de regras, a partir de um tema e suas variações, havendo várias referências musicais" à "simpática e deslumbrante Soraia Marina", ao "Rio Moldávia” de Smetana, entre outras; por outro lado, o vocábulo 'fantasia' remete, etimologicamente ${ }^{6}$, para a "aparição de coisas extraordinárias, que causam ilusão", anunciando o desenlace deste romance-filme, em que intervêm divindades, responsáveis pelo happy ending da história.

Num romance que se quer do século $\mathrm{xxI}^{7}$, o autor continua a dar asas à imaginação e criatividade, a lembrar um outro romance - $O$ Livro

* Este artigo corresponde, no essencial, ao publicado na revista Ágora. Estudos Clássicos em Debate (Aveiro, Universidade de Aveiro, 2005), dirigida por João Manuel Nunes Torrão.

1 Carvalho (Lisboa 2003). Todas as citaçôes serão feitas a partir desta edição.

2 Em Outubro de 2004, Mário de Carvalho obteve, com este romance, o Prémio de Novelística do Pen Clube Português, patrocinado pelo Instituto Português do Livro e das Bibliotecas.

3 Silvestre 1998: 213.

4 "Mário de Carvalho: crónica do aturdimento": JL - Jornal de Letras, Artes e Ideias 864, 12/11/2003, 12. Entrevista de Maria João Martins.

5 Morais e Silva 1953: s.u. 'fantasia'.

6 Machado 1995: s.u. 'fantasia'.

7 "É altura de começarmos a pensar no romance do século Xxi. E, como já não tenho a veleidade de matá-lo, acho que podemos prosseguir este caminho, no qual novas formas se ligam, se aglutinam e contribuem para dar objectos completamente diferentes. A verdade é que estamos impregnados de imagens, do cinema aos computadores e aos bonecos da Marvel”, afirma o autor. "Que raio de país é este?”: Visão 561, 04/10/2003, 174-178. Entrevista de Sara Belo Luís. 
Grande de Tebas, Navio e Mariana -: rompe com diversas convençóes literárias, recriando fábulas, personagens e ambientes; recorre a múltiplos estilos narrativos, que faz situar em diferentes tempos históricos e em outras esferas, e a peculiares relaçóes paródicas e intertextuais, que se manifestam nas citaçóes e nas frases recorrentes, e serve-se da inter-venção irónica de um narrador de feição camiliana ${ }^{8}$, com o objectivo de traçar um retrato impiedoso de um país em crise política, económica e social. A função do escritor, um pouco à imagem do teatro vicentino, é divertir o leitor, através da ironia subtil, e denunciar a vulgaridade e o prosaísmo do tempo desencantado em que vivemos, procurando "endireitar o mundo"?.

Como instrumentos poderosos que proporcionam histórias divertidas e que podem desencadear o riso, Mário de Carvalho lança mão de dois recursos: a já referida ironia e a paródia. Termo de difícil definição, a 'paródia'10 tem sido alvo de inúmeras abordagens e tentativas de descrição. Definido por Linda Hutcheon como "inversão irónica", "repetição com distância crítica que marca a diferença em vez de semelhança" ", ou "irónica "transcontextualização" e inversão, repetição com diferença"12, a paródia não é uma categoria única na literatura que se convencionou chamar de pós-moderna, pois é localizável em muitos textos das literaturas grega e latina ou na literatura trovadoresca, tendo chegado até nós através da literatura moderna ${ }^{13}$. Na prática, isto significa que o conceito de paródia tem sofrido alteraçóes ao longo do tempo. Entendida no âmbito literário, a paródia é vista por L. Hutcheon, que segue Genette, "como uma relação formal ou estrutural entre dois textos"14, o que, para muitos estudiosos, equivale a dizer que se está no domínio da intertextualidade. No entanto,

8 Melanda 2001: 38. Dissertação de Mestrado em Estudos Portugueses, apresentada à Universidade de Aveiro. Exemplar em CDRom.

9 Mário de Carvalho: "Pátria Lusitana - O retrato, a ironia e o desencanto": Os Meus Livros 19, 02/03/2004, 43. Entrevista de Cândido Oliveira Martins.

10 Vide Ferreira 2003: 279-300, onde o autor apresenta um erudito artigo sobre as várias definiçốes e teorias em torno deste conceito. Consulte-se também a introdução a este volume da autoria de Miguel Mora (2003) 7-13, onde, de forma simples e clara, se define o que é a 'sátira', a 'paródia' e a 'caricatura'. Veja-se, ainda, Ferreira 1999: 113-137 e 2000.

11 Hutcheon 1989: 17.

12 Hutcheon 1989: 48.

13 Melanda 2001: 90-91.

14 Hutcheon 1989: 34. 
na transcontextualização "está implícita uma distanciação crítica entre o texto em fundo a ser parodiado e a nova obra que incorpora, distância geralmente assinalada pela ironia” ${ }^{15}$. Ora, isso implica falar do cómico, do humor que a paródia sempre deve incluir. Hutcheon, na linha de Martin $\mathrm{Kuester}^{16}$, refere que à paródia não tem de obrigatoriamente corresponder o cómico. No entanto, como refere P.S. Ferreira, "ainda que, enquanto termo técnico musical, a paródia tivesse um ethos sério, a verdade é que, na acepção da paródia literária, o termo aparece quase sempre associado ao cómico"17. Focando o nosso olhar no autor que está na base deste estudo, concluímos que a paródia, em Mário de Carvalho, não abdica da distanciação irónica permitida pelo riso ${ }^{18}$. Como o próprio escritor refere, "o humorismo é a forma mais, não sei se diga mais eficaz, mas é com certeza a mais próxima de exprimir o desencanto"19. Assim, a única saída possível perante a sensação geral de desencanto é a ironia, a única forma possível de seriedade ${ }^{20}$.

Nas páginas que se seguem, procuraremos vislumbrar em que medida a referência a outros textos e autores pode ser veículo de humor, procurando identificar as suas implicaçóes, sob o ponto de vista ideológico, para o entendimento da obra.

\section{Em busca da autenticidade perdida}

O romance é uma singular viagem por um país tagarela, falador, que ninguém consegue calar (ao telemóvel, nas esquinas, nos jornais, nas televisôes), mergulhado numa profunda crise social e económica, e que se refugia, com frequência, em assuntos menores, em busca de uma autoestima colectiva. O falatório é geral, de norte a sul, atingindo todas as classes e profissões e "é causa de inúmeros despautérios, frouxas produtividades e

15 Hutcheon 1989: 48.

16 We should note again that the fact that there is a semantic element accompanying the structural changes does not imply that these changes have to be in the direction of humorous or comic effect. Kuester 1992: 7.

17 Ferrreira 2003: 296.

18 Cf. Melanda 2001: 90, nota 51.

19 Cotrim 1996: 45.

20 Hutcheon 1988: 39: "In fact irony may be the only way we can be serious today". 
más-criaçōes" (11). Para esta verborreia colectiva muito têm contribuído os telemóveis, para muitos, a melhor invenção dos últimos tempos!

O país não tem nada a dizer, a ensinar, a comunicar. O país quer é aturdir-se. E a tagarelice é o meio de aturdimento mais à mão (11).

É neste contexto que surgem dois coronéis que resolvem, por diferentes razóes, deixar Lisboa e fixar-se no Alentejo. Um chama-se Bernardes e dorme com uma metralhadora $U z i$ debaixo da almofada; o outro tem por nome Lencastre, nasceu em Goa e tem um filho, o Nelson, que gosta de pintar todas as paredes brancas com tags e grafitis. Ambos são casados. Maria das Dores é a mulher de Bernardes, é de famílias ricas, teve uma educaçáo selecta que não "jogava" nada bem com a linguagem vernácula que utilizava, estando a preparar uma tese de mestrado na Universidade de Évora, intitulada "O traje feminino entre os Povos originários da Lusitânia Tarragonense”. Maria José é a esposa de Lencastre, gosta de agricultura e de decoração. O coronel Bernardes, na sequência de um mau jeito nas costas, lembrou-se de construir uma piscina. Lencastre, para fugir ao filho, decidiu viver perto de Bernardes. Para além de serem militares, o que os une verdadeiramente é o ódio ao país tagarela.

Para a construção da piscina é preciso haver água. Emanuel Elói é um jovem vedor, racional, bondoso e mestre de xadrez, contratado por Bernardes para desencantar lençóis freáticos no seu monte, junto de Serpa. Emanuel, por sua vez, tem um tio virtual que aparece sem avisar, a despropósito, e que tenta corromper o narrador, para que este náo maltrate o sobrinho durante o romance.

O coronel Bernardes, como referimos, decidiu rumar ao Alentejo "numa atitude de protesto" (25) em relação aos vizinhos do prédio, que decidiram pôr em causa a sua administração do "condomínio da Rua de Santo Estêvão à Lapa" (28). Dores incentivou-o a abandonar o cargo, antes de ser demitido. Juntou-se assim o útil ao agradável:

Ala para o Alentejo, para os grandes espaços, o apartamento de Lisboa ficava para as excepçóes. Antes a rústica simplicidade que o contacto com a melíflua e falsa gente que não prestava preito à competência de mando de um cidadáo que passara a vida a dar provas (31). 
Há, neste exílio ${ }^{21}$ do coronel, perante o vexame de quem sente a sua autoridade posta em causa, o desejo de voltar para uma autenticidade perdida, de contactar com a Natureza:

Mal se haviam instalado, o coronel Bernardes começou por entoar loas a tudo o que descortinava ao redor, o humilde alecrim, a melancolia dos rebanhos, a vida simples e filósofa dos pastores, os ritmos retardados das horas, a fauna, que bom, a flora, que bonita, os nativos, que gente (32).

Este topos da procura do campo como resultado do cansaço da cidade tem tanto de contemporâneo como de antigo. Lembremos o Rato do Campo da famosa fábula de Horácio ${ }^{22}$, que só aprecia os bens que possui quando experimenta a sua ausência. Portanto, só a partir da cidade se pode desejar o campo. Já na cultura helenística, este sentimento aparecia de modo intenso: o melhor exemplo talvez seja a poesia bucólica que teve como impulsionador Teócrito, um grego que tinha nascido numa megalópole, Siracusa. Nos seus Idílios mostra-se o gosto pelos ambientes e personagens rústicas, ao mesmo tempo que se procede à exaltação da paisagem.

Virgílio, numa temática estritamente pastoril, compôs as Bucólicas, onde se contempla a paisagem campestre, a silua, com uma nostalgia e devoção mais intensas. Um exemplo evidente desse desejo do campo e da repulsa da cidade está nas palavras de Córidon ${ }^{23}$ :

21 Usamos o termo 'exílio' por sugestão do próprio narrador, que antes referira: "Agora importa reflectir a relaçâo historicamente comprovada entre o vexame e o exílio. Nâo faltam os casos em que um elevado conceito de honra ou dignidade leva a recusar a sombra, em vida, e os ossos em morte, às pátrias. A escala deste coronel era, convenhamos, mais modesta. Não chegava à dimensão de toda a Pátria” (31). Os coronéis Bernardes e Lencastre procuram o campo não tanto pelo otium mas para, à volta da piscina, comentarem os problemas do país com "uma visão distanciada e lúcida" ("Mário de Carvalho - Crónica do aturdimento”: $J L, 12 / 11 / 2003,11)$. Dá-se, assim, “a substituição do otium pelo exílio, ou seja, da estabilidade emotiva e da serenidade arcádica pela problematizaçáo e pela angustiante sensação de queda", como refere Cardoso Bernardes 1988: 20, nota 2 .

22 Horácio, Sátira 2, 6. Veja-se a este propósito o artigo de Cristóbal (1992) 131-143.

23 Virgílio, Bucólicas 2, 61-62. A tradução é de Mendes 1997: 194-5. 
... Pallas, quas condidit arces

ipsa colat; nobis placeant ante omnia siluae.

... More a própria Palas nas cidadelas que

fundou; a nós agradem-nos os bosques, acima de tudo.

A própria filosofia antiga enaltecia a qualidade de vida no campo. Os estóicos defendiam uma existência natural e selvagem e repudiavam todo o artifício da civilização. Para os discípulos de Epicuro, o campo era o local ideal de vida para o sábio. E uns e outros louvavam as vantagens de uma vida retirada.

Em suma, a literatura, espelho de mitos e realidades, sempre testemunhou esse desejo humano pela Natureza. Hoje, ao mesmo tempo que o homem pensa na natureza como cenário de liberdade, teme pela sua destruição e inquieta-se com a preservação do meio ambiente. Por isso, ao decidir construir uma piscina no monte alentejano, o coronel Bernardes atenta contra esse locus amoenus, impondo àquele espaço natural, algo de extremamente artificial:

Lá em baixo, na paisagem, incrustada na duríssima permanência das coisas, onde só mandam altos castelos, menires e cromeleques, destoa azulínea, e sobressalta, com a transparência, a piscina, modernaça e tratada a poder de fluidos caros e especiosos (19).

Apesar disso, o narrador alega o seguinte em defesa dos coronéis:

... é justo arguir que eles náo guardam arames entre as ramagens das árvores, não deixam sacos de adubo ao vento, não abandonam velhas máquinas e engrenagens na charneca, náo largam entulhos nas carreteiras, não matam abetardas e outras aves protegidas, não envenenam faunas predadoras, não cortam chaparros para lenha, não plantam eucaliptos e mimosas, não ateiam queimadas em Agosto, não atiram para o cháo cascas de melancia, não se esquivam aos impostos, não intrujam nos negócios e, de uma forma geral, separam os lixos, isolam as pilhas, ensacam o conjunto e, com regularidade, acabam por deixar tudo no contentor camarário mais próximo... (20).

É óbvia a simpatia do narrador para com os coronéis. Ao contrário da maioria dos seus concidadãos, eles náo atentam contra a Natureza nem contra o meio ambiente, cumprem os seus deveres de cidadania e não prejudicam os semelhantes. 


\section{O paradigma do novo-rico}

Construir uma piscina, porém, implica ter posses. No caso de Bernardes a sua construção começou por ser uma necessidade. É certo que sempre poderia deslocar-se à piscina de Serpa, como lhe sugeriu a Dores (64). No entanto, o Coronel, tal como os senhores da Roma Imperial, que possuíam, nas suas uillae, balneários privativos, rende-se à evidência de que a "hidroterapia é que está a dar" - como leu no subtítulo de um jornal -, mas nada de se deslocar a Serpa: a piscina "queria-se era ali, em pleno campo, privativa, ao dispor, alumiada e amornada pelo valente sol alentejano...” (64). E dá-se início à construção. A cratera estava já aberta e foi alvo de uma visita nocturna, por parte do coronel. Por momentos, sentiu-se um latifundiário, dono de um bom pedaço de terra, se escavasse sempre até ao centro da terra. Ao olhar para o céu negro "confrontou-se com a ideia de que também era proprietário de todo o espaço sobrejacente até Plutão, até aos confins do Universo" (125).

O coronel nunca tinha lido Petrónio, porque o romano nunca se ocupou de coisas militares, e naquele instante em que contemplava a grandeza quase infinita dos seus domínios não podia saber que um tal Trimalquião já tinha procedido a um raciocínio aparentado, mas na horizontal, à uma, por se encontrar deitado, à outra, por considerar apenas o caminho terrestre entre Roma e África" (125).

O passo do Satyricon a que se alude é conhecido (37.8):

Ipse Trimalchio fundos habet, qua milui uolant, nummorum nummos. Argentum in ostiarii illius cella plus iacet, quam quisquam in fortunis habet.

Quanto a Trimalquião, tem propriedades por onde os milhafres podem espraiar o voo, rios e rios de dinheiro. Há mais prata pelo chão do quarto do seu porteiro que muita boa gente tem no seu património. ${ }^{24}$

Trimalquião é o protagonista de um episódio famoso e único: a Cena Trimalchionis. É um liberto cuja riqueza é imensa e, ao longo da cena, há muitos pormenores que nos dáo conta dessa realidade. Este fragmento faz parte do retrato feito por Hérmeros, o qual denota uma certa admiração

24 Seguimos a tradução de Leão (1998) 100. 
pelo sucesso conseguido pelo novo-rico, em boa parte devido ao dinheiro que a sua capacidade empreendedora realizara e que podemos ler nas suas próprias palavras:

Quicquid tangebam, crescebat tanquam fauus (76.8)

Coisa em que eu pusesse as mãos, medrava que nem favo de mel $^{25}$

A referência ao voo dos milhafres é proverbial. O milhafre, voando alto no céu e com uma vista penetrante, é observado pelos augúrios nas evoluçôes significativas, e normalmente ligado a Apolo como símbolo de clarividência ${ }^{26}$. Neste sentido, apesar dos pensamentos de Bernardes aparentarem tiques de novo-rico ${ }^{27}$, à maneira de Trimalquiáo, eles denotam antes de mais a clarividência de alguém que sendo militar na reforma, se sente investido de autoridade para poder comentar, na companhia de Lencastre, as venturas e desventuras das personagens da actualidade, seus vícios e atitudes, muitas delas merecedoras de reprovação. A piscina é um local agradável e simbólico, à volta do qual se fazem essas conversas. É como se ela deixasse de servir para as funções que lhe estão destinadas e passasse a ser apenas o pretexto para o encontro e conversa dos coronéis. A piscina, até pelo formato rectangular, simboliza Portugal, a um tempo local e assunto de conversa.

Nunca aqueles dois deram um mergulho camarada na piscina. Uma única vez tinha ela sido usada pelo coronel Bernardes e por Maria das Dores. Fora no dia da inauguração, com Felismina a presenciar, sem ter muito a certeza de que estava de acordo com aquilo (149).

Embora a gozar de boas reformas e com uma vida confortável, os coronéis mais do que corresponder ao paradigma do novo-rico, têm a função de apreciar as atitudes de personagens como Januário. Oriundo "duma daquelas terras do Norte com o nome acabado em 'elo', ou 'oso', ou 'ais'”, (188), Januário, o pai de Sandra, encarna aqui o verdadeiro paradigma do

25 Leão 1998: 103.

26 Chevalier, e Gheerbrant 1994. Tradução portuguesa de Cristina Rodriguez e Artur Guerra, s.u. 'milhafre'.

27 Convém lembrar que o coronel Bernardes é um antigo capitão de Abril, militante de esquerda durante o PREC, que acabou por casar com a filha de um latifundiário e ter uma vida confortável, passada entre o condomínio fechado de Lisboa e a piscina no Alentejo. 
novo-rico. Tendo feito uma comissão em África, enriqueceu à custa de negócios pouco claros, entre os quais a exploração de imigrantes ilegais. Revela, por isso, alguns dos traços distintivos que caracterizam o novo-rico: a ostentação das riquezas (o automóvel Saab, uma vivenda que se destaca das outras); a gabarolice ("Diz que tem uma casa com quatro elevadores e uma arca frigorífica sempre a abarrotar de marisco", 189); a arrogância e a prepotência ("Aliás, comigo ninguém faz farinha, ouviu?", 58); a linguagem vulgar e grosseira, nomeadamente quando joga uma partida de xadrez com Emanuel ("Mas que merda é esta? Falamos chinês, ou o caraças?", 59); o excesso de comida e de bebida ("enchia de uísque um grande copo de conhaque e atirava-se a uma pratada de gambas", 57); e a parolice, na maneira como se veste ("blaser preto, com botóes redondos de lata dourada, calça amarelo-torrado, e camisa cor-de-rosa”, 52). Todos estes traços evidenciam o contraste entre a ostentaçáo de poder e a figura caricata da pessoa que a motiva ${ }^{28}$.

\section{A paródia da epopeia}

Para além da semelhança de pensamentos entre o Coronel e Trimalquião, outros paralelismos podem ser estabelecidos entre as duas histórias e respectivas personagens. Entre a época de Nero e a actualidade há um grande hiato temporal, mas a uni-las está uma profunda crise social, com as instituiçóes a perderem credibilidade e autoridade. Tal como no romance de Petrónio, em Fantasia para dois Coronéis e uma piscina, os heróis, ou anti-heróis, andam constantemente em busca de dinheiro e de aventuras de amor ${ }^{29}$. Façamos um breve elenco das personagens e comecemos pelas masculinas:

A personagem principal é um jovem alto, veste ganga azul, um pólo claro, cor de burro quando foge, e os cabelos, nem curtos nem compridos, foram desamigados de pente há muito tempo (14). "É daquelas figuras que inspira simpatia e confiança a um primeiro olhar, mesmo de longe. Chamase Emanuel Elói, é uma bondade de moço, trotamundos, e tem algum jeito e muita paciência para os seus conterrâneos" (14). O pai quis dar-lhe "um nome benigno e abençoado e fez uma lista de que constavam os seguintes: «Eloim, Adonai, Sadai, Soter, Emanuel, Sabahot, Tetragrammaron, Alpha

28 Vejam-se a este propósito os trabalhos de Leão 1996: 161-182; (1997) 147-167; e 2004: 191-208.

29 Cf. Medeiros 1997: 171. 
et Omega, Principium et Finis, Hagios, Ischiros, Otheos, Athanatos, Agla, Jehova, Homonsion, Ya, Iesus Christós, Messias, Elva, Elrei...» Mas o empregado do Registo Civil só aceitou Emanuel” (67). É também uma personagem da simpatia do narrador, um verdadeiro "deus connosco"30, que apesar de andar numa atitude constante de procura de realização, de felicidade, no seu Renault Quatro, trilhando os caminhos de norte a sul ${ }^{31}$, é o único que o faz de forma desinteressada, tendo atitudes de altruísmo como quando dá boleia ao apicultor Eleutério ${ }^{32}$. Este, por seu turno, pretende, com vinte litros de mel, realizar "a bela maquia de mil cento e noventa euros"(12), tendo destinado uma parte para comprar uma prenda para Irina, "porque as namoradas em pousio desertam" (12). Um pastor, sem nome, consegue uma indemnização de 100 euros de Bernardes ao simular um ferimento com molho de tomate na lã de um borrego (38-42). Nunes Norberto, o Nónó, está em Caxias, porque tirava músicas da net e "distribuía-as, a um preço simbólico" (50). Januário foi furriel, tem 50 anos, é presidente do clube de bola, vereador da câmara, sócio honorário dos bombeiros, tem uma padaria, uma fábrica de louças, três oficinas de automóveis, quatro lojas de electrodomésticos, duas casas de alterne, um bar e um bordel clandestino. Tem uma mansão com dois elevadores, como empregada uma imigrante russa, Natacha, que trabalhava num estabelecimento nocturno ${ }^{33}(52,188)$. O Tio do Emanuel, "monárquico,

30 Cf. Is 7,14: "Por isso, o mesmo Senhor por sua conta e risco, vos dará um sinal: olhai: A jovem está grávida e dará um filho, pôr-lhe-á o nome de Emanuel” (A citação da Bíblia é feita segundo a $8^{\circ}$ edição da Difusora Bíblica, editada em Lisboa, em 1978.

31 Como nos lembra Paula Melanda, "não é por acaso que a estrutura básica da acção nas diversas sequências narrativas de O Livro Grande de Tebas, Navio e Mariana e de outros livros de Mário de Carvalho, assenta em metáforas da progressão, tais como a viagem e a busca; encontros que tomam a forma de diálogos, de combates, de situaçóes de cerco e fuga..." (Cf. Martins (Lisboa 1983) 186-187). O Renault Quatro é o meio que permite a Emanuel Elói essa procura "que visa o encontro de uma pátria desimpedida, capaz de preencher o vazio deixado pela amputação que marcaria o pós-revolução; é em suma a demanda de uma pátria a que se possa chamar 'Pátria”" (Melanda 2001: 120-122).

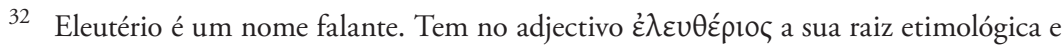
significa 'o que fala ou procede livremente; que tem sentimentos de um homem livre'. Remete-se, portanto, para a liberdade ( $\dot{\lambda} \varepsilon \cup \theta \varepsilon \rho i ́ \alpha)$ conseguida com o 25 de Abril, contudo, nem sempre exemplarmente vivida, simbolizada na cena em que Eleutério e Desidério, aquando das escavaçôes para a piscina, atentam contra o património arqueológico encontrado (ânforas e um mosaico), possuídos por um desejo (desiderium) desenfreado de enriquecer: "Estavam convencidos de que as ânforas poderiam estar cheias de moedas" (128).

33 Januário revela-se uma autêntica 'porta' (ianua) de entrada para a mão de obra estrangeira. O nome próprio é a transcrição do substantivo latino Ianuarius, que dá o nome ao mês da passagem de um ano a outro, 'Janeiro'. Etimologicamente liga-se a Ianus, 
extravagante, mulherengo" (66), é adepto da técnica da triangulação, isto é, $\mathrm{a}$ arte de bem se relacionar com quatro mulheres ao mesmo tempo. "A primeira, ad quem, não conta, porque é a que desfecha a situação. Não faz parte do triângulo: obriga ao triângulo" (167). Afonso Tovar, fuzileiro, envolveu-se com uma garota, a Filipa, empregada bancária. Primeiro foi viver com ela, depois "envolveu-se à porrada com um ex-namorado dela e foi parar ao banco do hospital, com vários pontos" (187).

Se os homens não são heróis, não se espere algo diferente das mulheres. Destaca-se, pela positiva, a esposa do coronel Lencastre, Maria José, "prendada moça, de linhagem militar" (72), tem atitudes carinhosas para com o marido e revela compreensáo para com a rebeldia do filho Nelson. Pela negativa, por uma ou outra razão, destacam-se as restantes: Maria das Dores, esposa de Bernardes, procura aventuras; sente-se fortemente atraída por Emanuel, desde que o vê pela primeira vez, a ponto de se meter na sua cama, no fim da história. Mantém uma relação com o Tio do Emanuel, sendo uma das mulheres da triangulação. Irina é a "conversada" (36) do apicultor, imigrante de leste, sente também ela forte atracçáo pela personagem principal: passam a noite juntos "na penzan Rosmaninio" (38). Natacha é uma emigrante russa, trabalhava num estabelecimento nocturno, agora é criada de servir em casa de Januário. Sandra tem um Smart, foge com Emanuel na noite em que este estivera a jogar uma partida de xadrez com o pai dela. Passam a noite juntos. Angelina, empregada do bar da estação de serviço, estava a namoriscar com o segurança, quando aparece Emanuel. Com a chegada da claque dos adeptos de futebol e iminente destruição da loja de conveniência, atrela-se a Emanuel, fazem amor no Renault Quatro e, no fim, cobra-lhe 50 euros. Tia Felismina, empregada doméstica do casal Bernardes, reclama o seu quinhão numa eventual partilha de moedas, que supostamente estariam nas ânforas, descobertas por Desidério e Eleutério. Filipa, empregada bancária, alimenta a paixão por Afonso Tovar.

Um olhar atento sobre algumas destas personagens permite-nos concluir que, tal como no Satyricon, há uma crise dos paradigmas tradicionais: os mais velhos, "em tempos de indefiniçáo, devem funcionar como guia e baluarte do bom gosto e de uma conduta apropriada"34. Isso, porém, não

'Jano', um dos mais antigos deuses do panteão romano, representado por dois rostos que se opóem. Atribuem-se ao seu reinado as características da Idade de Ouro: a honestidade dos homens, a abundância, a paz profunda, situadas nos antípodas das características reveladas por Januário. Consultem-se Grimal e F. Martin, s.u. 'janus'.

34 Leão $2004^{\mathrm{a}}$ : 233-234. 
acontece no romance: Maria das Dores, traindo o coronel, deseja o jovem Emanuel; o Tio deste dá instrução ao sobrinho no âmbito da triangulação; a Tia Felismina revela a mesma ambição pelo lucro fácil, como os jovens Eleutério e Desidério; o pastor, sem nome, simula um ferimento num animal para conseguir uma indemnização de 100 euros do coronel. Os mais velhos não são mais os heróis, nem os modelos para as geraçôes mais novas.

Estas personagens, espelho da vulgaridade que caracteriza o quotidiano, e os pormenores realistas com que nos são apresentadas mostram o prosaísmo do mundo desencantado em que vivem. $\mathrm{O}$ narrador, porém, à boa maneira clássica, invoca a sua musa inspiradora:

... gentil Polímnia, grácil musa que por mim zela, e que não rejeito invocar... (17)

Musa excelente e demais luzidas divindades... (20)

Nô mais, ficção, nô mais! Desce tu, Musa, a de sorriso loução... (227)

$\mathrm{O}$ assunto do romance não é, como já vimos, elevado, não canta os feitos sublimes de um herói ou heróis. A invocação da musa Polímnia ${ }^{35}$ só pode ter aqui um efeito paródico. Com efeito, o heroísmo, que é adequado na epopeia ${ }^{36}$, é posto a ridículo por uma narrativa que só para o parodiar o convoca. Podemos afirmar com Marie-Heléne Robilliard que "o autor, historiógrafo desenganado, escreve uma História que está nos antípodas da epopeia, opondo ao sentido da epopeia uma sensação de absurdo, à glorificação do heroísmo a sua paródia e ao fresco histórico a história de pessoas simples e anónimas" ${ }^{37}$.

Estas pessoas simples e anónimas, na era da comunicação, que utilizam o telemóvel descontroladamente, revelam, paradoxalmente, dificuldades em comunicar. E, como se sabe, incomunicabilidade gera desencontro. Ao nível das relaçóes familiares, o desencontro fica bem patente nas relaçóes entre pais e filhos, paradigma do tradicional conflito de geraçóes. Exemplo

35 Polímnia é uma das nove Musas, filhas de Zeus e de Mnemósine. Segundo a tradição, teria inventado a lira e descoberto a agricultura. Vide Grimal, s.u. 'Polímnia'.

36 Num outro passo, faz-se alusão a uma das epopeias clássicas: "Daí a umas horas, vinha perto a manhã, já toava a orla do céu a aurora de róseos dedos" (p.61). Cf. Odisseia 2.1 "Quando surgiu a que cedo desponta, a Aurora de róseos dedos..." Homero, Odisseia (Lisboa 2003), tradução de Frederico Lourenço.

37 Robilliard 2002: 96. 
disso é o relacionamento entre o coronel Lencastre e o seu filho Nelson: quando se encontram, desconversam (o que é já de si uma negação da conversa), mantêm falsos diálogos, para não dizer monólogos, como aquele em que Nelson, depois de ter falado sozinho, é agredido fisicamente pelo pai e expulso de casa (73-75). Algum tempo depois, as saudades levam Nelson a questionar-se: "Mas porque raio é que o velho não usa telemóvel?" (167).

A comunicação entre marido e esposa é outra dificuldade. Também a este nível há desencontros. $\mathrm{Na}$ obra, estão bem documentadas as relaçóes conflituais dos homens e das mulheres desta geração, tal o número de situaçôes de infidelidade e de traição descritas, que atingem todas as personagens, das mais às menos relevantes: Irina troca Eleutério por Emanuel; Angelina troca o segurança por Emanuel; Afonso Marinheiro troca a esposa Madalena por Filipa; Lopes Geraldo troca a mulher por outra; um alentejano, a fazer uma comissão em África, é informado da traição da mulher pelos seus familiares; e Dores acumula Bernardes com Emanuel e o Tio deste - "Gosto de coleccionar. Sou aditiva. E depois?" (185).

Este assunto alimenta as conversas dos coronéis. Eles sabem que tanto se pode ser vítima de traição como se sentir impelido para trair.

Em suma, um gajo, pá, tem de se rodear de todas as cautelas. «Se não fores casto, sê cauto ${ }^{38}$, como dizia o outro (193).

Bernardes era vítima de traição e ele sabia. O que ele não queria acreditar era que Dores o tentasse trair mais uma vez, na sua própria casa, com o hóspede Emanuel. $\mathrm{O}$ narrador anuncia o adensar trágico, fazendo ecoar Horácio ${ }^{39}$ :

38 Tosi (2000) 700, referencia esta máxima na sua correspondente latina Si non caste, saltim caute, dizendo que ela é de origem desconhecida. Para além da paronomásia caste / caute, importa salientar que castus tem, em latim, um significado mais amplo do que o nosso casto, pelo que, originariamente, a sentença não se restringiria apenas à prudência necessária com os amores furtivos. Os provérbios, os adágios, as máximas, enquanto fragmentos de narrativas ancestrais, são usadas pelos coronéis como síntese da sua experiência e apresentadas para proveito e exemplo (prodesse et delectare) dos leitores. Cf. Melanda 2001: 132-133.

39 Horácio, Ode 1.11.7-8: Dum loquimur, fugerit inuida aetas. Esta expressão da celebérrima ode do Venusino anuncia o sintagma já tantas vezes citado: Carpe diem. Nesta ode, o poeta começa por advertir Leucónoe ('espírito branco') a não sondar o futuro, pois "sofrer" o futuro é, antes de mais, estar presente para o viver (cf. Tony dos Santos Ferreira (1990), "Carpe diem - Breves pensamentos de um pensamento breve" Boletim de Estudos Clássicos 13: 154). Ironicamente, o coronel Bernardes, neste passo, é semelhante a Leucónoe, 
Mas as horas transcorrem, todas ferem, a última mata, e, enquanto falamos, eis que o invejoso tempo foge (216).

A responsabilidade dos desencontros entre homem e mulher é, inevitavelmente, das mulheres. É esta a posição misógina do Tio de Emanuel. As longas esperas a que ele tem estado sujeito, os "esforços, tédios, cansaços, desânimos e vexames" (89), que ele tem suportado em nome da sedução deixam-no amargurado. Enumera depois uma série de situaçóes, algumas das quais se encaixam nos caracteres femininos descritos por Semónides de Amorgos ${ }^{40}$, num fragmento ímpar da poesia arcaica grega, em que o poeta oferece uma reflexão sobre a natureza feminina. Estas queixas, porém, não devem levar o seu sobrinho à desistência:

Eu quando enumerei as dificuldades e complicaçôes que há no trato com as mulheres estava a preparar-te para a vida. Para não desistires à primeira e aguentares a pé firme. (...) Enunciei uma tipologia, aliás bastante incompleta. Admito - isto um tipo, após os gregos antigos, tem a obrigação de ser justo - que do lado delas existam tipologias equivalentes (160).

As razōes de queixa são antigas e, pelos vistos, são mútuas...

\section{Deus ex machina}

Neste ambiente "de desencanto, a marginalidade parece uma opçáo inevitável”»ł1. Nelson, Neusa e Tiago são, tal como Encólpio, Gíton, Ascilto, intelectuais vadios, uma espécie de hippies sempre disponíveis, que vivem de expedientes. É certo que os de Fantasia... não são tão perversos. Mas vivem no seu mundo, andam numa caravana, sem rumo, nem destino. Usam linguagem diferente, vestem-se e penteiam-se diferentemente, usam piercings, fumam droga, partilham a caravana, que tinha sido, inclusive, "comprada a meias" (162). Os temas de conversa, porém, fogem da vulgaridade: falam de artes, de cinema, "da amizade, lealdade e confiança entre

isto é, ingénuo, não na sua credulidade de conhecer o futuro, mas quanto à infidelidade tentada de Maria das Dores com o jovem vedor Emanuel.

$\begin{array}{ll}40 & \text { Brasete 2003: 39-56. } \\ 41 & \text { Medeiros 1997: } 172 .\end{array}$ 
as pessoas" (163). Deixam as suas marcas (tags) nos sinais de trânsito e nas paredes brancas, para afirmação da sua diferença. Sobrevivem de trabalhos manufacturados - uma "bandeira portuguesa feita de caricas", um "CristoRei de caracóis" - e de contribuiçóes generosas, que a mãe de Nelson lhe dá, sem Lencastre saber. À margem do viver social, protestam passivamente contra a sociedade do seu tempo, demarcando-se da procura desenfreada do lucro fácil. A rejeição de Tiago por tudo o que de mau esta sociedade representa está bem patente no seu grito:

Geraçôes caducas, os gajos já cá deixaram o que tinham a deixar e nunca mais se vão embora. (159)

O desencanto poderia ser resolvido se o homem reencontrasse o caminho do divino ${ }^{42}$. Há, na obra, apariçóes de deuses que deixam entrever uma réstia de esperança contra o pessimismo. Emanuel é bafejado por essa presença. A primeira aparição dá-se quando a personagem principal se desloca a uma estação de serviço para atestar o depósito do Renault Quatro:

Uma estação de serviço, a salvação. Sem antecedentes nem provocaçáo, ocorreu a Emanuel aquela imagem dos sonhos, de um deus dependurado de uma grua que lhe aparecia de súbito em frente, a vociferar (103).

Uma outra aparição é razão para Emanuel dar boleia a um desconhecido, que por acaso era o seu Tio:

Mas duas razóes levaram o jovem Emanuel a trilhar os calços. A primeira é que, ao passar pelo castelo do Alvito, hoje apousadado, tinha distinguido, nos adarves duma torre, uma figura, desta vez feminina, de capacete parecido com o dos bombeiros, uma coruja ao ombro, muito resplandescente, a ponto de sobrepujar os holofotes da Câmara e que parecia ter sido ali depositada, no momento, por uma grua da construção civil (156).

As apariçóes repetidas, ora de um deus, ora de uma deusa, numa clara paródia à intervenção do deus ex machina, conferem ao romance essa dimensão de sonho, fantasia e humor, principalmente, quando se 'transpor-

42 Medeiros 1997: 172. 
tam' da cena do teatro clássico do século v a.C. as maquinarias teatrais, que contribuíam para o aumento da espectacularidade dos processos cénicos,

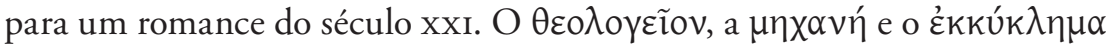
eram recursos cénicos utilizados pelo dramaturgo para as teofanias finais, isto é, para fazer aparecer um deus, em voo, no final da peça, com o intuito de repor a harmonia e a tranquilidade perdidas ${ }^{43}$.

Através da "figura que empunhava um arco de fantasia", o narrador, usando a auto-ironia, resgata o protagonista, Emanuel Elói, de uma situação desesperada: a fuga da casa do coronel Bernardes, depois de Dores, qual ninfomaníaca, ter solicitado os seus favores sexuais, exclusivamente para satisfação da sua libido (222). O 'Anjo da Guarda' de Emanuel não permitiu que ele perecesse na cena de perseguiçẫo final em que se dá o $h a-$ ppy ending: o coronel Bernardes, com a honra ofendida, varre tudo à volta com a metralhadora $U z i$, dando largas à sua autoridade; Emanuel é poupado; Nelson Lencastre, com a caravana, atraído pela luminosidade, aparece e reencontra-se com o pai "num amplo, pesado e terno abraço" (226).

Alargando o âmbito da interpretação, o aparecimento de um deus ex machina, numa scaena, onde tudo remete para a vulgaridade, justificase como sendo uma chamada de atenção ao homem, para a existência de outros valores. Emanuel é o único a quem os deuses aparecem, a ter atitudes de altruísmo para com os seus concidadãos, a revelar alguma indiferença pelos valores materiais, a usar a inteligência (e.g. jogo de xadrez).

$\mathrm{O}$ aparecimento de Atena ${ }^{44}$ sugere o uso da inteligência em detrimento da força, a defesa da civilização perante a barbárie. Atena usa a inteligência para os heróis ultrapassarem as piores dificuldades. Foi assim com Ulisses,

43 Deus ex machina é uma expressão latina, tradução da locução grega $\theta$ cò $\mu \eta \chi \propto \nu \tilde{\eta} \varsigma$, usada no âmbito teatral, nomeadamente por Eurípides (séc. v a.C), para designar o aparecimento de deuses e heróis suspensos num engenho ( $\mu \eta \chi \alpha \nu \eta ́)$, colocado à esquerda da cena, em plano elevado, com o intuito de resgatar prodigiosamente os protagonistas de alguma situação desesperada na parte final das peças de teatro. Para além da $\mu \eta \chi \alpha v \eta ́$, exis-

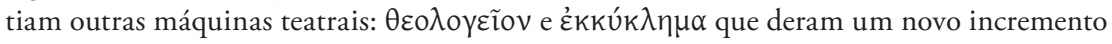
ao espectáculo teatral, aumentando a criatividade, a ponto de algumas peças de Eurípides, e.g. Andrómeda, Hércules Furioso (822 sqq., 872), Andrómaca 1226-1232), terem sido parodiadas por Aristófanes, por causa das suas novidades revolucionárias. O recurso à $\mu \eta \chi \propto v \eta ́$ e às teofanias finais nem sempre foi bem visto pelos antigos. Horácio, por exemplo, diz, a este propósito, nec deus intersit, nisi dignus uindice nodus / inciderit (De arte poetica, 191-2). Sobre a definição deste dispositivo e sua utilização consulte-se Silva 1987: 156-161 passim; Duncan 1935: 126-141; Schmidt 1963: 88-112; Dunn 1985: 111-167.

44 Sem nomear explicitamente a deusa Atena, o narrador fala apenas de "uma figura, desta vez feminina" e refere uma das suas insígnias: um "capacete parecido com o dos 
que regressa a casa depois da guerra de Tróia. Quanto a Emanuel "foi por a deusa ter indicado aquela estrada, de entre caminhos e direcçóes possíveis, que ele a escolheu" (156).

\section{5. "Falhou a Revolução?"}

Daqui decorre uma aposta na instrução e na cultura para fazer face a uma sociedade sem valores, rendida aos tiques do novo-riquismo, ao telelixo televisivo, à música pimba (que a cantora Soraia Marina tão bem personifica), que embrutece e que faz as delícias de um país inteiro, onde há bárbaras claques de futebol que destroem estaçôes de serviço.

É necessário mudar mentalidades, apostar na educação e no civismo. A voz da jovem Sandra reclama-o em tom de lamento: "Ainda há muita coisa a aperfeiçoar na nossa democracia" (50). É como se 30 anos depois do 25 de Abril chegássemos à conclusão de que muito falta fazer relativamente ao desenvolvimento, em áreas como a justiça, a educação, a ciência, a segurança social, a saúde... Neste sentido, como refere o historiador Luís Trindade, "a análise da actualidade portuguesa, hoje, constrói-se invariavelmente sobre uma comparaçáo com as expectativas da Revolução; no caso de Fantasia para dois coronéis e uma piscina é como se Mário de Carvalho chamasse a atenção para o falhanço do ideal de Abril" ${ }^{45}$, pelo menos no que à participação cívica diz respeito.

Mas falhou a revolução? "Não posso dizer-lhe isso porque me recordo de como era o país" ${ }^{\text {" }}$, contudo o isolamento proporcionado pela caravana atesta bem o descomprometimento político provocado pelo desencanto pós-revolucionário.

Cabe à literatura o papel de "organizar o mundo" e porventura "de conseguir o riso e a gargalhada", através da ironia e da paródia de textos de autores clássicos, gregos e latinos. "Nós, por vezes, pensamos que estas coisas dos Romanos não têm importância nenhuma e que são coisas antigas, velhas. Mas não. Nós estamos a falar em latim, estamos a falar uma língua latina, porque os romanos estiveram cá e deixaram-nos esta herança.

bombeiros", além de "uma coruja ao ombro, muito resplandecente" (156), o seu animal favorito. A lança e a égide eram as suas outras insígnias. Cf. Grimal, s.u. 'Atena' e 'Palas'.

45 Trindade 2004: 20-31.

46 Luís, Sara Belo, entrevista a Mário de Carvalho “Que raio de país é este?”:Visão 561, 04/10/2003: 174178. Entrevista de Sara Belo Luís. 
Os autores desse tempo ainda nos estáo a falar. Somos o mesmo homem. Não há grandes diferenças entre o homem daquele tempo e o homem de hoje. Por isso é que conseguimos ler as obras do passado e elas nos podem entusiasmar tanto" ${ }^{\prime \prime}$.

Tirar do passado o proveito e o exemplo, para evitar cometer os mesmos erros dos antepassados, parece ser a liçáo maior a tirar desta Fantasia. Afinal, voltando ao passado talvez se possa "interrogar as raízes de um presente em deriva de valores e certezas" ${ }^{\prime \prime 4}$. Hoje como ontem...

47 Mário de Carvalho, em entrevista a Ana Sousa Dias no programa "Por outro lado": A Dois 29/03/2004.

48 Júdice 1997: 97-98. 


\title{
A Paixão do Conde de Fróis: paródia e subversáo
}

\author{
Ana Paula Arnaut \\ Centro de Literatura Portuguesa / FLUC
}


(Página deixada propositadamente em branco) 
A Paixão do Conde de Fróis de Mário de Carvalho $\left(1986^{2}\right)$ consubstancia a ilustração perfeita de uma certa tendência post-modernista que parece considerar que "o trabalho de emendar é o único que nunca se acabará no mundo", até porque "o reino da terra é dos que têm o talento de pôr o não ao serviço do sim" ${ }^{3}$, mesmo que esse "não" surja apenas travestido de problematização mais do que de negação absoluta. A citação é de um outro escritor, José Saramago, mas não temos dúvidas em usá-la a propósito do romance de Mário de Carvalho. Este recupera o tempo perdido da História com a plena consciência de quem entra num jogo em que a ironia e a metaficção, bem como as emendas semânticas e formais e os acrescentos da lavra da sua imaginação, fazem implodir sentidos e factos tradicionalmente tidos por inatacáveis. Longe, portanto, de uma atitude discreta, respeitosa e (pedagogicamente) nostálgica, que consistiria em "reproduzir ponto por ponto os factos conhecidos", Mário de Carvalho entretece "dados históricos não mais que suficientes num tecido ficcional que se manterá predominante"4.

Neste romance, onde claramente se afirma a possibilidade de dispensar alguns elementos caracterizadores do passado ${ }^{5}$, as ilaçóes ideológico-subversivas são, por conseguinte, sobejamente interessantes, quer no que diz respeito à História religiosa quer no que se refere à História laica, as duas faces de uma mesma moeda que, afinal, se revelam indispensáveis para o conhecimento de uma época.

Considerado por Fernando Mendonça como "no fundo, uma história de padres[,] [p]ois, como o próprio A. diz (72), «padres é o que não falta na literatura portuguesa»" -se de acintoso e jocoso espírito crítico. Um espírito crítico que, pela leitura inversa e irónica das homologias traçadas, serve os propósitos de uma grotesca caricatura de uma parcela da sociedade de setecentos:

A Paixão do Conde de Fróis seria uma historieta sem consequências, se não fosse o minucioso e expectante desenvolvimento da acção. No percurso narrativo, vão-se construindo simbolicamente os aspectos que caracterizam a sociedade portuguesa, a do século XviII, que no fundo

\footnotetext{
1 Texto retirado e adaptado de Arnaut, 2002: 324-354.

2 Todas as citaçôes são feitas a partir da $3^{a}$ edição (1993).

3 Saramago, 1989: 14 e 330, respectivamente.

4 Saramago, 1990: 19.

5 Carvalho, 1993: 173.

6 Mendonça, 1997: 104.
} 
é a dos séculos subsequentes. A nobreza teimosa, surda aos apelos do povo, o povo que é o pau-mandado da nobreza e náo sabe porquê. $\mathrm{O}$ clero, que na sombra manipula a nobreza e o povo. Este é, de facto, o pano de fundo de $A$ Paixão do Conde de Fróis, a paixão de ser capaz de reconstruir uma fortaleza absolutamente inútil7.

Mas o título remete para mais do que essa paixão que torna a personagem capaz de reconstruir a fortaleza. De acordo com a linha subversiva de consecução do alternativo tratamento post-modernista da(s) História(s), julgamos que o que também se pretende é traçar um paralelo, dessacralizante e risível, com o solene sentido bíblico da paixão de Jesus Cristo, que desde a prisão no horto à expiração na cruz sofre inúmeros e indignos tormentos.

Do mesmo modo(!), também o nosso protagonista, no início apresentado como dado a estroinices de índole diversa (é precisamente por isso desterrado para S. Gens, onde deve assessorar o comandante da praça), sofre, progressivamente, uma semelhante via crucis de incompreensão, desencadeada pelo inexplicável e assombroso empenho com que pretende defender a praça que acaba por interinamente comandar.

Além disso, e agora no que respeita à incorporação irónica de referências intertextuais num discurso histórico consagrado e não sagrado, a personagem é também pomposamente (e premonitoriamente) descrita pelo parlamentário espanhol (esse que se desloca à praça de S. Gens para negociar a rendição dos sitiados) como misto de Calígula e de Heliogábalo ${ }^{8}$. Os epítetos nada abonatórios ridicularizam, pela desproporção da comparação, a figura deste conde que, pela sua obsessão e teimosia compulsiva, granjeia a antipatia do povo. $\mathrm{O}$ mesmo povo que, motivado pelo padre capelão, manhosamente frustra os intentos de manutenção do domínio de

\footnotetext{
7 Ibid.:.104.
}

8 Ver ibid.: 151. Calígula (n. 12 e assassinado a 41) inicia o seu reinado sob ventos auspiciosos mas, ao tomar conhecimento de que largos milhares de vítimas haviam sido sacrificadas aos deuses para que estes o livrassem da doença que sofria, torna-se delirante de sangue e de uma brutalidade que não mais o abandona. Heliogábalo (n. 204, m. 222), vítima também de assassinato, protagoniza um reinado de devassidão, infâmia e crueldade. Interessante e não menos premonitoriamente simbólico e irónico parece ser o facto de $S$. Gens ser o espaço escolhido para o desenrolar da acçáo, pois, de acordo com a hagiografia, este santo que dá origem ao topónimo foi um mártir romano. Em qualquer dos casos apontados ressalta a ideia náo apenas de morte violenta, mas de morte provocada por outrem - precisamente o que acontece ao conde de Fróis cuja morte decorre de ruidosa manobra da população, que prefere entregar-se aos sitiantes a continuar a sofrer as suas investidas. 
uma praça que, aqui, parece duplicar, com cores inversas mas não menos irónicas e caricatas, essa outra de facto protagonista de cerco e de conquista historicamente atestados e imputados ao marquês de Sarriá.

Referimo-nos ao episódio do cerco de Almeida, entre 7 e 25 de Agosto de 1762. Com efeito, a determinação obsessiva e doentia do marechal de campo Alexandre Palhares parece ter inspirado Mário de Carvalho na construção do seu protagonista. No entanto, se ambas a figuras se aproximam pela incompetência demonstrada (e pelo ridículo das situaçóes em que se envolvem), elas afastam-se na medida em que o primeiro contraria ordens superiores, acabando por optar pela capitulaçáo da praça, porque é movido por uma extremosa preocupaçáo em defender os interesses da populaçáo ameaçada pelos intensos bombardeamentos dos sitiantes.

Ora, em A Paixáo do Conde de Fróis, se é certo que o grotesco nobre é apresentado como tendo sofrido uma metamorfose comparada à de "S. Paulo a caminho de Damasco", a verdade é que esta comparação não pode senão ser lida à luz de um espírito contrário e, mais uma vez, dessacralizante. Não se trata, pois, de uma transformação conducente ao dealbar de uma mais humana e generosa personalidade, trata-se, sim, de uma intensificação de características que de um estroina civil fazem um compenetrado estroina militar, o qual, empenhado na criação de um mundo muito seu, não hesita em abater o tendeiro revoltoso que se preparava para, das muralhas, agitar o pano branco da rendiçáo:

O pano branco removeu-se junto à muralha, no meio do tropel. Oscilou, numa hesitaçáo breve. Logo o tendeiro o tomou, e com ele alçado, subiu a correr pela escada das muralhas, sem que alguém, nem os soldados de serviço lá em cima, lhe travasse o passo. Prosseguiu pelos adarves, aos saltos, com a bandeira bem alto. Depois parou, fazendo-a pendular largamente dum lado para o outro.

$\mathrm{O}$ tiro, seco, reboou, levantando um estralejar arrastado de pequenas ressonâncias pelas paredes além ${ }^{10}$.

A preocupação em atingir uma excessiva competência de estratega redunda, portanto, em derradeira instância, numa incompetência caricata que se traduz na impossibilidade de gerir diplomaticamente as relaçóes entre civis, padres incluídos, e militares.

\footnotetext{
9 Carvalho, 1993: 27.

10 Ver ibid.: 166-168.
} 
Se os conflitos que estabelece com a sociedade envolvente parecem fazer do protagonista um tipo de herói canónico, nomeadamente o do Romantismo de oitocentos, a verdade é que, mais uma vez, prevalece a subversão e a consequente dessolenização. Características que decorrem, agora, não apenas de uma englobante urdidura irónica ${ }^{11}$ (onde, como veremos, desempenham papel fundamental os comentários metaficcionais do narrador que do século xx revisita o passado), mas também do modo como grotescamente se delineiam os traços físicos da personagem em questão:

Sobre o baixo, escanzelado, com o ombro esquerdo ligeiramente descaído, em consequência duma justa de touros infeliz que lhe amassou costelas e retorceu a clavícula, parecia ligeiramente disforme, com os braços de comprimento desmesurado e pernas muito esguias, tortas e nodosas. O olhar era mortiço, cínzeo, parado, sonolento. A face comprimia-se abaixo das fontes, para recuperar espaço na zona da testa, larga e protuberante, a contrastar com o afunilamento do queixo. Não havia peruca que lhe servisse, antes se dispunham tortas e indiscretas logo ao primeiro uso, deixando entrever, por debaixo, os cabelos cortados cerce, finos e arruivados.

A boca traçava-lhe a cara, quase de extremo a extremo (...).

A voz saía-lhe roufenha, pesada, arrastada, quando não hesitante ${ }^{12}$.

O contraste dessacralizante, e que sempre redunda em sorriso irónico, entre a solenidade das referências intertextuais e o ridículo de uma situação que se insiste em levar demasiadamente a sério, seja pelo conde de Fróis seja pelo espanhol marquês de Alagon (igualmente casmurro nos seus desejos de vencer um cerco que, em última instância, se fica inadvertidamente a dever a um carvoeiro que se arroga o direito de tentar afugentar os espanhóis ao hiperbolizar as grandezas das defesas de S. Gens ${ }^{13}$ ), ocorre, ainda, em outra situação. Reportamo-nos ao episódio em que, a propósito da

11 Sobre a ironia nesta obra de Mário de Carvalho, bem como sobre as possíveis ilaçôes cómicas, ver Sequeira, 1996: 23-27 e 83-90.

12 Carvalho, 1993: 74-75.

13 Ver ibid.: 120 (ainda a propósito do episódio do carvoeiro, ver ibid.: 105). Depois do interrogatório em que a personagem declara a existência de "mais de vinte canhōes e quatro batalhóes, fora os homens da milícia, sob o comando do conde de Fróis, experimentado oficial das guerras de Mazagão e da Índia", o marquês de Alagon, "passou em torno um olhar triunfante sobre as faces perplexas e inquietadas do seu Estado-Maior", ao mesmo tempo que mentalmente reprovava os "senhores oficiais que queriam passar de largo..." 
preparação dos trabalhos deste cerco de uma praça que nem sequer "vinha no mapa", se estabelece a comparação entre Sarriá e o responsável por esse outro cerco de dimensóes escatológicas protagonizado pelo "imperador Tito em frente de Jerusalém"14.

$\mathrm{O}$ que assim se consegue, afinal, é a manutenção de mais uma das características do Post-Modernismo enquanto fenómeno por vezes contraditório, já que

usa e abusa, instala e depois subverte, os próprios conceitos que desafia - seja na arquitectura, na literatura, na pintura, na filosofia, na teoria estética, na psicanálise, na linguística ou na historiografia ${ }^{15}$.

É caso para perguntar, pois, "Que seria de nós se não fosse o deleatur"16?. Sem a sua carga simbólica, que aqui convocamos para legitimar a paródia à(s) $\mathrm{H}(\mathrm{h})$ istória(s) do cerco da praça de $\mathrm{S}$. Gens, que mantém a menção a outros referentes históricos (Pacto de Família, o contexto englobante de um cerco que decorre na Guerra dos Sete Anos, reinado de D. José, os nomes de Sarriá ou de Lippe-Schaunberg), não seria possível a plena aceitação da modelização pessoal que se inscreve no xadrez narrativo. Não seria também possível o acatamento da subversão da máscara séria da História levada a cabo neste romance cujas páginas, ainda que indirecta e enviesadamente, expóem e denunciam, auto-reflexivamente, o carácter viciado e selectivo do trabalho de pesquisa dos historiadores.

Ao evocar o episódio histórico também conhecido como «Guerra Fantástica», Mário de Carvalho joga e entretece os dados históricos com os resultantes da sua imaginaçáo de um modo mais discreto do que o que observamos em romances de outros autores, mas a verdade é que o resultado não se traduz numa revisitação do passado menos inocente ou mais nostálgico. Assim, apesar de na dedicatória de A Paixão do Conde de Fróis se aproveitar o ensejo para alvitrar a inserção do romance no campo da fantasia, ou apesar de, desde o início, ser possível detectar a presença de um tom irónico e jocoso, o leitor mais ingénuo (ou menos habituado às convençóes subversivas do Post-Modernismo) é certamente impelido a

pois, "já se via a chegar ao cerco de Bragança com a artilharia e tomadias de S. Gens, pondo em evidência a inépcia dos que, antes dele, haviam subestimado a praça”.

\footnotetext{
14 Ibid.:.174 (118 para a referência anterior).

15 Hutcheon, 1991: 19.

16 Saramago, 1989: 16.
} 
esquecer estes indícios e a aceitar o universo narrado como credível, porque conforme, neste primeiro andamento da narrativa, a um pacto de leitura canónico, já cultivado nos romances históricos de Alexandre Herculano, por exemplo. De facto, não apenas se não expóem ou debatem abertamente questôes colateralmente relacionadas com a reconstituição histórica e com a aberta problematização da História, como, além do mais, os exercícios metaficcionais ou auto-reflexivos apenas se fazem sentir de forma mais sistemática quando a engrenagem da $\mathrm{h}(\mathrm{H})$ istória vai já adiantada, sensivelmente a partir do primeiro terço da obra.

O desvendamento metaficcional de que a narrativa é manipulada pela entidade que do presente coevo preside ao discurso (disso se valendo para, numa íntima e tácita relação com o destinatário extra-literário atestar, apesar de tudo, a veracidade dos factos ${ }^{17}$ ) só ocorre claramente quando, a propósito da chegada de uma missiva trazida por um anspeçada do regimento de Miranda (e cujo conteúdo permanece desconhecido para o padre capeláo), se comenta sobre o privilégio de conhecimentos que autor e leitor virtualmente detêm ${ }^{18}$.

A partir deste momento sucedem-se e intensificam-se os comentários que, de forma mais ou menos explícita, anunciam uma orientação da leitura em estreita cumplicidade com o leitor, ao mesmo tempo que atestam a subjectividade da interpretação dos sujeitos/materiais históricos:

Era destarte, sem tirar nem pôr, que o conde interpretava aquela tineta do padre de o arredar da praça, e distrair dos seus deveres e compromissos. Interpretava bem, interpretava mal? O leitor o dirá. Mas convém ir-se lembrando de que o padre, ao invés de muito sacerdote caceteiro e brigão do seu tempo, o que mais prezava era o sossego e a pacificação;

17 Carvalho, 1993: 105 e 125, respectivamente: "Tanto traste foi enterrado debaixo da lareira, ou entalado nos interiores de granito, que ainda hoje os amadores de antiqualhas e bricabraques lucrariam com a pesquisa, nanja os de panelas de ouro, que não as havia”, "Habitualmente os leitores estarão afeiçoados a um certo dramatismo nestas mortes. Considera-se sempre que o passamento de alguém é um acto tão importante que há-de rodear-se e empavesar-se de trejeitos e ademanes rituais e anunciadores. Nos filmes de agora, por exemplo, como é que é? Os cavaleiros acusam o golpe, estorcem-se, levam a mão à ferida, balanceiam de frente para trás e de trás para a frente, dobram-se sobre a montaria, descaem a cabeça à altura do arção, e lá acabam por cair em grande espectacularidade. Na vida real, como esta que se conta é, não ocorrem assim as coisas" (destacados nossos).

18 "Mas já que o padre não soube [o que se dizia na carta], saibamo-lo nós que, autor e leitor, temos esse privilégio", ibid.: 58. 
Qualquer apreciaçáo sobre um homem, desde que se não seja deus - é o caso do autor que suspeita de que, neste particular, também tem a cumplicidade do leitor -, vem sempre frouxa, contingente e incompleta. Serve para se ir vivendo. No caso dos autores, para se ir escrevendo;

Eu agora simplifiquei. Os projectos do padre não eram assim tão pensados;

Importa agora dizer como era este padre? Penso que náo, que vai ele muito aviado com o feitio que lhe foi conferido e não carece de mais acrescentos. Padres é o que náo falta na literatura portuguesa. Sáo mesmo de longe muito mais abundantes que os condes, de modo que posso considerar a imaginaçáo do leitor suficientemente habilitada a compor este sacerdote, no físico e demais atributos aparentes. Basta que era cinquentáo, baixo e largo./E, retomando o fio - que a interrupção aproveitou um instante em que o étimo e a declinação de nudiustertius foram ali esmiuçadas -, ouve-se o padre perguntar — Então, senhor conde, e como vai isto de guerra? (... $)^{19}$.

Estes comentários (que enviesadamente contaminam a linearidade e a veracidade dos factos históricos expostos) começam a obrigar, por conseguinte, a uma reapreciação do já lido. Em consequência, eles instauram, também, uma mais premente necessidade de pesquisa paralela em relatos oficialmente acreditados a fim de confirmar as suspeitas tardiamente instauradas de que, afinal, A Paixão do Conde de Fróis não é uma mera revisitação do passado histórico.

Pelo contrário, o romance assume-se como uma recriação subjectiva de onde, por um lado, se não ausentam possíveis teias ontológicas ao real do que foi e do que aconteceu, e em que, por outro lado, é legítimo ler a ideologia de um autor/narrador subtilmente empenhado não na construção de um suplemento da historiografia oficial (como o faria Walter Scott ou, posteriormente, os seguidores de uma linha tradicional ${ }^{20}$ ), mas na utilização lúdico-irónica do material histórico.

Desta utilização não se encontra isenta, convém sublinhar, uma linha de acintosa crítica, já inicialmente indiciada a partir da citação de Fernando

19 Ibid:.72, 73, 76 e 80 (destacados nosso).

20 Ver Wesseling, 1991: 42. 
Mendonça, a um certo conjunto de padres que desde tempos imemoriais percorrem a literatura portuguesa.

Para além dos notórios traços caricaturais respeitantes à personalidade do mal amado capelão da família Fróis, vítima primacial dos acintes do narrador que, desse modo, relega para segundo plano o 'pobre' vigário de S. Gens, é de toda a utilidade apontar a influência e a importância desta personagem no desenrolar último dos acontecimentos que culminam na morte do conde.

É como se, obliquamente, se atestasse o exercício extensional de uma manipulaçáo provinda da entidade religiosa, que, sempre mais preocupada em fazer valer pessoais desígnios e uns tantos privados confortos, náo olha a meios para conseguir os seus fins, mesmo que tal implique, numa exortação muito pouco ortodoxamente católica, pedir auxílio ao diabo, caso este esteja disponível ${ }^{21}$ !

Se em algumas das apreciaçóes feitas é visível o prolongamento do paradigma metaficcional a que vínhamos aludindo ${ }^{22}$, a verdade é que ele se estende, ainda, numa aliança aparentada com técnicas cinematográficas, à movimentação protagonizada pelo narrador para melhor observar e reger os acontecimentos:

Deixemos estas entretengas mornas de tiro demonstrativo, e deixemos o padre - ala que se faz tarde! - a caminho de casa, e apreciemos melhor como tudo se passou à janela e perto do conde, que é o sítio de melhor vista;

Prossigam eles as congeminações e os inventários, sisudamente, que o tempo nos dá para irmos ao arraial espanhol, ver como se dispóem as coisas. (...) Vista de perto ["Toda aquela gente"], com olhos do autor (que os tem de gato, assim lhe fosse também o fôlego...), na noite negra, a azáfama lembra o remexer de uma colónia larvar;

21 Carvalho, 1993: 54. Registemos ainda a emblemática súmula que o narrador faz desta personagem: "A paciência grande é a dos Beneditinos ou a dos santos. Ele não era nem uma coisa nem outra (...)" (65).

22 A propósito da possibilidade de comparação entre o capelão e o espanhol cónego adunco (ibid.: 115-117), por exemplo, o narrador/autor arroga-se o direito de peremptoriamente afirmar o definitivo afastamento do segundo da história que conta. 
Tudo visto, volte-se às muralhas e, dentro delas, à torre de menagem onde o conde conferencia com os seus oficiais e o prior vai dormitando, à espera $(\ldots)^{23}$.

O que assim se póe em relevo é um claro e assumido domínio sobre a matéria contada ${ }^{24}$, velada por vontade própria ${ }^{25}$ ou por respeito a uma verdade que sempre se contraria e ficcionaliza ${ }^{26}$ porque, afinal, não há que respeitar uma representação realista do mundo histórico. Como depreendemos de confissão ostensiva e impertinentemente tecida a propósito de certa táctica militar, não existe, inclusivamente, qualquer pudor em assumir a ignorância e/ou o desconhecimento de coisas sobre as quais sabe tanto como de grego ${ }^{27}$.

Apesar de frequentemente se chamar a atenção para a delimitação de fronteiras entre História e ficção (quer pelos registos metaficcionais, manifestos ou dissimulados quer por outras estratégias discursivas, entre as quais contamos a ironia e a manipulaçáo dos registos de linguagem), o certo é que esta diferenciação acaba por se diluir, até porque o narrador, ou o autor, pontualmente evidencia o respeito pela verdade histórica, como sucede no seguinte exemplo:

23 Ibid.:167, 174 e 176 (destacados nossos).

24 "Enquanto aguardava os outros, garatujou uma lista de assuntos numa ardósia, que a ocasião requeria poupança de papel e nem em tudo, por mais prudente, o conde se havia sabido prevenir, como melhor veremos mais adiante"; "A ordem, numa longa fieira, desde o pormenor miúdo às questôes decisivas, era longa, enfadonha, e se o leitor a náo dispensar, dispenso-a eu. Basta referir que os três homens andaram às voltas com o incêndio na casa do feno, procurando remédio para o sustento do gado, e chegaram prestes à conclusão de que havia pouco fornecimento de madeiras e carvốes para o lume (...)”, ibid: 172 e 173, respectivamente (destacados nossos).

25 "Grande confissão [a do "senhor conde"] havia de ser, tomando em linha de conta os acontecimentos últimos. Respeitemos-lhe o sigilo", "Num ressalto, meio ocultada por entulhos, escoras, e por uma parede nova de reforço, furava a velha porta gótica, chamada da traiçáo, como em outras praças, por razóes semânticas que náo cabe aqui referir”, ibid.: 180 e 196 respectivamente (destacados nossos).

26 "Por pudor, omitam-se as alusões, nem todas verdadeiras, com que o capitão de cavalaria foi brindado, e cheguemo-nos mais ao final da conversa, de novo derivada para a apreciação das circunstâncias do cerco (...), ibid.: 191.

27 "Era própria e adequada esta táctica militar? Não mo perguntem a mim que me limito a contar a história e sei tanto de assédios militares como de grego. Era assim que eles procediam. Se bem, se mal, julgue-o o leitor, ou, se não quiser julgá-lo, suspenda o juízo, como o outro... Dessarte me avenho eu...", ibid.: 185. 
Seria talvez a altura de o autor, que nunca no decorrer da narraçáo deixou de mostrar alguma admiraçáo pelo conde e governador de $S$. Gens, lhe pôr na boca ou no pensamento uma tirada dramática, de burilado recorte, dando conta do agastamento com a traição que assim era perpetrada. Mas a história tem os seus pruridos de verdade que se sobrepóem às parcialidades do autor e este vê-se constrangido a relatar o que ao conde calhou dizer, e não o que ele gostaria que o conde dissesse ${ }^{28}$.

Em suma, talvez para a História, e para as histórias da História, valha apenas a justíssima asserção de que "a verdade não pode ser mais do que uma cara sobreposta às infinitas máscaras variantes" 29 . Estas concretizam-se, em derradeira instância, não só na consecução do que John Woods designa por modalidades mistas de existência ${ }^{30}$, isto é, na convivência no universo narrado de personagens, acontecimentos e lugares aceites como históricos, com personagens, acontecimentos e espaços ficcionais, mas também no facto de em cada uma destas categorias poderem, eventualmente, coexistir as duas linhas de força: a histórica e a ficcional. "En ce sens", como diz Ricoeur, "la fiction emprunterait autant à l'histoire que l'histoire emprunte à la fiction" 31 .

\footnotetext{
28 Ibid.: 199-200 (destacados nossos).

29 Saramago, 1989: 26.

30 Woods, 1974: 41-42.

31 Ricoeur 1983: 154.
} 


\section{"Como dizia o outro": a presença dos Clássicos em Mário de Carvalho}

Virgínia Soares Pereira

Universidade do Minho 
(Página deixada propositadamente em branco) 
Um dos sinais da vitalidade dos textos clássicos consiste no facto de continuarem a exercer um grande fascínio junto dos autores contemporâneos, que se tornam, por sua vez, seus leitores e deles nos dáo novas visôes e interessantes intuiçôes. ${ }^{1}$ A leitura dos clássicos é, sem dúvida, a mais autêntica forma de conhecer a Antiguidade grega e latina. Todavia, num tempo em que o conhecimento das línguas nas quais se plasmaram os textos fundacionais da nossa tradição literária ocidental se vai tornando cada vez mais raro, voltar aos Clássicos implica estar aberto a múltiplas e diversas formas de revisitação, como sejam a tradução, a citação, a alusão, a reescrita, a recriação ficcional, a encenação teatral, adaptaçôes cinematográficas ou a divulgação em banda desenhada.

Por outro lado, o homem do nosso tempo já não está interessado em fixar o olhar no passado mais ou menos distante. Prefere, olhando para o passado com os olhos fixos no presente, iluminar ambos os tempos, o antigo e o moderno, em simultâneo e como que num jogo de espelhos recíprocos. Neste movimento, a atitude pode ser de aceitação (e até veneração) dos clássicos, ou de desapreço e rejeição. Deixou-se de falar em tradição e em "legado", conceitos que implicavam um passar do antigo ao moderno em sequência unívoca e cronológica, e passou-se a encarar a recepção dos clássicos como um caminho de dois sentidos que projectam a sua luz um sobre o outro, mutuamente, revisitando textos antigos e perscrutando neles aspectos que ainda náo tinham sido considerados, ou por terem sido marginalizados ou esquecidos, ou mesmo por não terem sido compreendidos. ${ }^{2}$

De todas estas formas de acesso aos Clássicos, aquela que tem colhido maior atenção por parte do público é a do romance histórico. Este género de texto tem a seu favor, para o leitor moderno comum, o apresentar uma visão particularmente atraente da Antiguidade Clássica, pois o que caracteriza e verdadeiramente importa no romance histórico não é tanto a exactidão dos dados, mas sim a pretensão de recriar uma "atmosfera histórica", em geral muito mais animada e colorida do que aquela que os dados secos da historiografia costumam dar.

1 Veja-se García Jurado (1999: 77) que considera a literatura latina uma literatura para ser lida e náo apenas para ser estudada por um pequeno grupo de especialistas. Sobre esta nova forma de transmissão e apropriação dos Clássicos, veja-se Salvatore Settis (2006), autor de uma das mais fascinantes reflexôes sobra a importância do Clássico, não como herança morta, mas como poderoso estímulo para nos compreendermos a nós próprios e ao Outro.

2 Cfr. Martin Winkler, em recensão ao livro de Lorna Hardwick, 2003: 4: “(...) the twoway relationship between the source text or culture and the new work and receiving culture". 
No presente artigo, veremos como Mário de Carvalho, um dos mais profícuos e premiados escritores contemporâneos, além de "compulsivo" leitor dos Clássicos, recria situaçóes e ambientes que nos transportam para o mundo Antigo - mítico, histórico e literário -, quer como forma de sublinhar a ironia subjacente a dada situação, quer no intuito de conferir à narrativa um pano de fundo rico de sugestôes. Particularmente representativas desta postura são duas obras que, quando surgiram, logo adquiriram assinalado êxito, a saber: o conto Quatrocentos mil sestércios, editado em 1991, que ganhou o prémio da Associação Portuguesa de Escritores, na modalidade, e o romance Um deus passeando pela brisa da tarde, igualmente galardoado com o Grande Prémio do Romance 1995, da APE. No primeiro, a acção decorre ficcionalmente em Salácia, num tempo posterior aos "tempos saudosos dos Flávios", como diz o próprio narrador (33), que coincide com a personagem principal; no segundo, estamos perante um romance histórico, que tem como palco dos acontecimentos a cidade (ficcional) de Tarcisis, no tempo do imperador-filósofo Marco Aurélio (121-180 d.C.). Movendo-se em tempos romanos, náo é de estranhar que o mundo romano esteja sempre diante de nós, quer mediante citaçóes mais ou menos evidentes, quer através de citaçôes encapotadas, isto é, de alusóes que, sem que o leitor comum disso se dê conta, remetem para obras clássicas de grande prestígio. Escritor cultíssimo, Mário de Carvalho evidencia um prazer especial em disfarçar as contínuas referências aos Clássicos. ${ }^{3}$ Ele mesmo o deixa entrever, ironicamente, em dado passo de Fantasia para dois coronéis e uma piscina, quando dois coronéis aposentados emitem opinióes sobre o romance literário (2004: 16):

— E as piscadelas de olho? Há gajos que se fartam de fazer citaçóes encapotadas só para ver se a malta dá por isso!

- Peneiras... Charadices...

Em rigor, este passo ilustra uma tendência muito própria de $\mathrm{MC}$, a saber, uma manifesta autoironia, se tivermos presente que a obra em questáo está recheada de alusóes e "piscadelas de olho". ${ }^{4}$

O conto Quatrocentos mil sestércios gira em tomo dos trabalhos por que passou a personagem principal, um jovem romano que se viu incumbido,

3 Uma entrevista de Carla Ferreira a MC, de 2003, tem o sugestivo título de "Mário de Carvalho. A arte de bem iludir o leitor".

4 Veja-se comentário a esta obra em Mendes 2005:129-150. 
inesperadamente, da responsabilidade de proceder à cobrança de uma dívida de quatrocentos mil sestércios. Estava em causa uma pequena fortuna, saliente-se, dado que este era o montante requerido para um romano ascender censitariamente à classe dos equites. Marco - assim se chama a personagem principal, que no nome evidencia já a sua condição de romano - é encarregado pelo pai de recuperar a mencionada dívida de quatrocentos mil sestércios. Ao cabo de peripécias sem conta, de venturas e desventuras, de muita sorte e ainda de mais astúcia, o jovem Marco - um rapaz dado a uma vida de estúrdia, à maneira do jovem plautino, e com pouca experiência das dificuldades do dia-a-dia - consegue desembaraçar-se da incumbência com êxito redobrado.

O conto situa-se em tempos romanos, como foi dito. A fim de recriar esses tempos, o narrador homodiegético compraz-se em utilizar um vocabulário do mais puro sabor latino e uma forma de expressão incomum nos nossos dias e que nem todo o leitor reconhecerá - estabelecendo-se assim uma espécie de cumplicidade entre o emissor e um receptor especial, como um piscar de olhos do autor ao leitor versado em matéria clássica. Tal atitude pressupóe um "código cultural comum entre produtor e receptor do texto", nas palavras de Maria de Fátima Marinho (1996:264).5

Para o efeito, $\mathrm{MC}$ recorre à simples transcrição para português de termos latinos próprios de determinados contextos, quando não recorre mesmo a latinismos, embora sem «avisar» que de latinismos se trata. Como disse o próprio autor, "importou do latim". Se vocábulos ou expressóes como 'átrio', 'triclínio', 'implúvio', 'paterfamílias', 'manes', 'chegar a penates', 'manumissão' são já banais e têm cabida em qualquer dicionário de língua portuguesa, outros constituem uma verdadeira surpresa. Estáo neste caso vocábulos como 'tablínio' (por 'tablino'?) para escritório, tonsor (para barbeiro), garum' (molho feito com tripas de peixe, indispensável em qualquer receita culinária romana), 'sidónios' (para fenícios ou árabes), optio (para designar um militar subordinado ao centurião), pilum (para dardo), 'cáliga' (para sandália), 'biga' (para carroça, ou carro de duas rodas), ou ainda as iniciais I. O. M. (Ioui Optimo Maximo, isto é, "A Júpiter muito bom e muito grande"), que requerem um leitor medianamente culto e conhecedor dos usos e costumes de gregos e romanos e da sua cultura. Além disso, reabilitam-se certos topónimos clássicos, aportuguesando-os. Assim,

5 Para a noção de paródia, congenial à narrativa pós-moderna, que requer não apenas a intenção do autor, mas também o reconhecimento do leitor, "sem os quais não haverá efeito paródico", veja-se Marinho (1996: 264). 
o Mediterrâneo passou de Mare Nostrum a Marenostro, Lisboa é Olisipo, Alcácer do Sal é Salácia, o Sado é Calipo, a península de Tróia (ou Setúbal) é Cetóbriga, Santiago do Cacém é Miróbriga.

Exemplos como estes ocorrem com frequência ao longo do conto. Limitam-se contudo a termos e expressóes bem conhecidos da tradição greco-latina. Diferente é o caso do trecho seguinte, que é uma espécie de "concentrado" paródico de sugestôes literárias associadas ao mundo clássico. Neste trecho, a seguir transcrito, o narrador (o próprio Marco), na pele do típico adulescens plautino irresponsável, ${ }^{6}$ dirige-se aos leitores e comenta como, durante um banquete, ele e os seus companheiros de estúrdia se entregavam a jogar aos dados (o que era proibido pela lei e pelos bons costumes do mos maiorum):

Meus amigos, para quê contar-vos o que já adivinhastes, vós, que não tendes o espírito toldado pelos passes de Baco e que, tranquilos, me ledes à sombra de uma faia, enquanto ao longe o pegureiro vigia ternamente o seu rebanho e uma brisa suave e perfumada varre as vossas terras úberes? Assim devera eu estar, em comunhão com os simples deuses agrários, cultivando-me e cultivando a minha mediania dourada, sob o pipilar dos pássaros, em vez de, repoltreado num triclínio escuro, passado de bêbedo, a balbuciar incoerências, a rir de facécias patetas, a apostar desvairadamente e a esquecer-me dos quatrocentos mil sestércios que lá jaziam, indefesos, em dois sacos de couro, sob o meu catre desalinhado.?

Sob esta tirada paródica, quantos hipotextos! Para além do topos do multa paucis, isto é, do topos que consiste em abreviar o que se tem para contar, aqui estão glosados o topos horaciano da aurea mediocritas, e o indissociável cultivo do espírito, bem como a descrição de uma paisagem bucólica em tons virgilianos, a ilustrar perfeitamente um outro topos, o do locus amoenus. A Bucólica I de Virgílio ali está, claramente, naquele "à sombra de uma faia", e é possível senti-la ainda naquela "brisa suave e perfumada" e nas "terras úberes" e no "pipilar dos pássaros"? A fim

6 Para um amplo comentário a esta faceta, vd. Rosana dos Santos (2009:225-229).

7 Num outro passo, descrevendo as arremetidas de uma ursa ferida (a terrível ursa Tribunda), o narrador diz: "Horrivel de ver, como dizia o outro" (68), evocando assim o horribile uisu de Virgílio. Ou ainda (30), numa alusão ao horaciano est modus in rebus: “( ... ) e, de resto, pensando melhor, como dizia o outro, em todas as coisas há uma medida”. 
de apreciar os mais diversos ingredientes da saborosa prosa de MC, o leitor tem de estar habilitado a reconhecer sob uma frase táo simples como "Nada mais delicioso que a vida do lavrador" (35) o epodo horaciano conhecido como Beatus ille, ou uma alusão ao final de um sentido poema de Catulo na exclamação do jovem Marco (41): "Coitado de mim, pobre Marco, esmagado na berma da estrada, na flor da idade...".

A somar a alusóes deste teor, pontuam o conto muitas outras sugestôes de índole mítico-literária, como sejam a comparação dos trabalhos de Marco com os trabalhos de Hércules, a alusão à viagem de Eneias saído de Tróia em busca de uma terra, e a referência à estratégia do fio de Ariadne (aqui transformado em uma fiada de moedas ao longo do caminho) para derrubar o Minotauro (isto é, a ursa Tribunda)! Pouco antes (p. 68), a ursa Tribunda era comparada, com vantagem, ao cão que guardava a entrada dos infernos:

E ali estava eu, desamparado, afundado na terra, a olhar para os sacos de sestércios, agora guardados por uma sentinela mais temível que o câo de sete cabeças que defende os infernos. ${ }^{10}$

Sugestóes e referências deste teor, propositadamente utilizadas em homologias desproporcionadas, têm o claro propósito de sublinhar o caráter herói-cómico das atribulaçóes do jovem Marco, que partiu em busca de um "tesouro" (leia-se: os quatrocentos mil sestércios) e regressará, ao cabo de muitos trabalhos - quase sempre resolvidos por outros, postos ao seu dispor pela sorte e pelos seus ardis -, com uma fortuna de mais de um milhão de sestércios.

8 Cfr. os versos finais do poema 11 de Catulo, que soam como uma espécie de despedida do seu amor por Lésbia: "que [ela] não espere mais, como anteriormente, o meu amor, I que morreu por culpa sua, como a flor da margem extrema do prado, / ao ser tocada pelo arado que passa..."

9 Neste passo, é o próprio narrador que póe a nu o texto subjacente, dizendo (71): "Devo confessar que, por entre os sobressaltos do susto, perdurou muito o orgulho deste meu expediente, nova versão altamente valorizada e adaptada com subtileza, da lenda do fio de Ariadne. E o furor daquela ursa bem valia o do Minotauro..." Observe-se, uma vez mais, o espírito paródico do passo. Para mais pormenores, veja-se Pereira (2002).

10 Note-se que o jovem, na tendência para o exagero que o caracteriza, transforma o cão trifauce, Cérbero, num cão misto de hidra de sete cabeças. Será Argus, o cão de guarda da casa, que acordará Marco para a dura realidade: o desaparecimento dos sacos. A respeito destas e de outras alusões à literatura e cultura clássicas, vd. o documentado estudo de Rosana dos Santos (2009: 202-242). 
Os comentários tecidos a respeito do conto Quatrocentos mil sestércios podem alargar-se a outras obras de Mário de Carvalho. Dificilmente haverá uma que náo brinde o leitor com fiapos ou fragmentos do mundo greco-romano, como acontece nos Contos da sétima esfera e em Era bom que trocássemos umas ideias sobre o assunto, ou ainda na peça de teatro Se perguntarem por mim não estou, obras nas quais as referências à antiguidade clássica se apresentam, como já é habitual em MC, mescladas de paródia ou ironia. ${ }^{11}$

Um dos Contos da sétima esfera, de 1981, intitulado justamente "Almocreves, publicanos, ricos-homens e ciganos" - em que há um misto inextricável de tempos e de épocas, sugeridos no próprio título ${ }^{12}$-, relata o que se passou com um publicano, cujas aventuras, juntamente com o ataque de tropas comandadas por um optio, envolvem o destino de uma ânfora que continha moedas de ouro. A acção decorre em Salácia (mas no final, nos tempos já modernos, o local da acção vem a ser Alcácer do Sal), o publicano desloca-se em liteira e passa junto ao quarto miliário, e a coorte que o protege é constituída por beduínos que usam o pilum como se fosse um cajado. ${ }^{13}$

Também no romance Era bom que trocássemos umas ideias sobre o assunto, de 1995, ocorrem algumas referências à Antiguidade, embora se possa dizer que, no geral, não passam de reminiscências avulsas que qualquer pessoa medianamente conhecedora dos grandes vultos da Antiguidade reconhece sem dificuldade. Assim acontece quando o narrador lembra Cipiáo e a forma como reagiu à sua "pátria ingrata», exilando-se volunta-

11 No caso da peça de teatro, que anda em torno do pânico causado por um pretenso tigre que se teria alojado no interior de um prédio na capital, uma das personagens, de nome Fernando, é professor de grego antigo e lamenta-se que já ninguém se interesse por tais matérias (vd. Pimentel, 2001: 183-185).

12 Esta forma de justaposição e sobreposição de épocas diferentes, que reaparece em várias obras de Mário de Carvalho, é um dos sinais do romance histórico pós-moderno e foi designada de "história paratáctica", por Amy Jeanne Elias, na sua análise de alguns romances históricos contemporâneos, conforme refere Maria de Fátima Marinho (1996: 265-267).

13 Para lá do seu interesse intrínseco, uma das curiosidades deste conto é que ele constitui, sem dúvida, uma espécie de esboço ou ensaio para a trama de Quatrocentos mil sestércios. Além disso, nesse conto marca presença a distracção da musa Clio, que, dormitando, baralhou os fios do tecido da história, tal como acontecerá com A Inaudita Guerra na Avenida Gago Coutinho, de 1983. Parece que MC gosta de retomar e recriar temas por ele mesmo anteriormente tratados. Note-se, por exemplo, que este último conto, comentando o castigo aplicado a Clio (ver-se privada de ambrósia por quatrocentos anos), termina deixando a suspeita de que outros possam vir a fazer o mesmo (35): “ o que, convenhamos, não é seguramente castigo dissuasor de novas distracçôes". 
riamente. $\mathrm{O}$ interesse da alusão é que ela serve para comparar a situação de Rui Vaz Alves, que reprovou em várias universidades portuguesas e só na Suíça conseguiu fazer o curso, com a de Cipiáo. Ora o desfasamento entre comparante e comparado é ironicamente abissal, como é evidente. Daí a ironia do comentário do narrador (19):

Zangado com a Pátria não lhe ocorreu o desprezo de Cipiáo que não consentia que a Ingrata tivesse os seus ossos, antes a ameaça de que Ela o havia de aturar, em carne e osso, quer o quisesse ou não.

Em Fantasia para dois coronéis e uma piscina, vindo a lume em 2003, abundam as alusóes proverbiais e as já referidas "citaçóes encapotadas". Citem-se, por exemplo, trechos da conversa dos coronéis sobre o romance:

"Eu, cá para mim, um livro deve apressar-se para o evento, começar logo a meio da coisa e eliminar os desvios e as imaginaçôes que só servem para encher. Um homem com pescoço de cavalo, por exemplo. Sonhos de doente, estás tu a ver? - Ai o gajo meteu um homem com pescoço de cavalo? - Não exageremos. Isto era eu a pensar...” (15). ${ }^{14}$

Ou:

"Em suma, um gajo, pá, tem de se rodear de todas as cautelas. 'Se não fores casto, sê cauto', como dizia o outro.” (193).

Ou também:

"Mas as horas transcorrem, todas ferem, a última mata, e, enquanto falamos, eis que o invejoso tempo foge (...). (216). ${ }^{15}$

Pode afirmar-se que não há obra de $\mathrm{MC}$ que não se faça eco das "reminiscências" que lhe ficaram das aulas de Latim e de Português e das imensas

14 São aqui notórios alguns ecos da famosa "Arte Poética" de Horácio, nomeadamente do começo, que fala do pescoço de cavalo, e do preceito que manda começar o poema épico in medias res.

15 Veja-se comentário a estas duas últimas citações em Mendes (2005: 143-144). A última citação reúne uma inscrição gravada num relógio de sol, que assinalava o passar das horas, e um hemistíquio de uma conhecida ode horaciana $(O d .1 .11)$. 
leituras que fez. Sáo, de um modo geral, referências esparsas e ocasionais, semelhantes a veios de um riacho que aqui e ali vão assomando à tona. Bem diferente é o que se passa com o romance Um deus passeando pela brisa da tarde, dado à estampa em 1994, assente num registo de grande densidade cultural, claramente perceptível já no belíssimo parágrafo inicial. ${ }^{16}$

A acção do romance decorre no tempo do imperador filósofo Marco Aurélio - mas termina quando já Cómodo reinava -, na segunda metade do século II d.C., quando as fronteiras do Império começavam a ser ameaçadas por bárbaros vindos do norte de África. Por essa mesma altura uma forma nova de vida espiritual, religiosa e moral, consubstanciada numa nova seita religiosa que se identificava com o sinal do peixe (em grego, IX $\Theta \mathrm{YO}$, iniciais de "Jesus Cristo, Filho de Deus, Salvador"), ia corroendo os alicerces imperiais e romanos. É neste "duplo pano de fundo - romano e cristão que se enquadra a ficção romanesca (Piwnik 2004: 139). Dividido entre o seu dever de cidadáo romano e a atracção do amor por uma jovem romana cristã, o duúnviro Lucius Valerius Quintius - a personagem principal -, que presidia ao município de Tarcisis, assiste, impotente, ao desmoronar de velhas certezas e convicçóes, incapaz de compreender que chegara ao seu termo um ciclo da sua vida individual e da vida colectiva da cidade, da Hispânia e até do Império. ${ }^{17}$ Mais tarde, já exilado na sua uilla, depois de ter renunciado ao cargo, o ex-duúnviro, ao ver um escravozito a traçar na areia os contornos de um peixe, ficou furioso e, como confessa, apagou o desenho com o pé. E o próprio comenta, no momento de evocar esta cena (19):

Acto inútil. Não se apagam as realidades destruindo-lhes os símbolos.

A realidade tem, afinal, muitos rostos. Com o seu gesto inútil, o romano revelou a sua incapacidade em compreender a profundidade da crise e em perceber que os tempos tinham mudado irremediavelmente. É profundamente significativo que o romance retome o tema no final, desta forma:

16 Sobre este romance e o seu brilhante começo, veja-se: Seixo (1995: 24-25) e Silvestre (1998: 220-222). Segundo este crítico, a abertura deste romance faz-se "em plena exploraçáo da retórica do incipit: com aquele que é o começo mais fulgurante, ou mais fulgurantemente literário da nossa narrativa contemporânea" (221). Vejam-se ainda as observaçóes pertinentes feitas a este começo, e ao romance, em Mendes [1999]: 348-349.

17 No que respeita a esta vertente do romance, que fala do colapso de todas as certezas e do mito da Roma aeterna, leia-se a análise elaborada por Natália Constâncio (2007: 59-77). 
Inquietou-me, é verdade, o pequeno escravo que desenhava um peixe, na areia, outro dia. Hoje sinto-me tranquilo. Afinal, o rapaz não sabia que sinal era aquele. Nunca ouviu, nem ouvirá, decerto, mencionar o deus que passeava no jardim, pela brisa da tarde.

E com estas palavras do narrador, de uma profunda ironia amarga, termina surpreendentemente o romance e a reflexão de $\mathrm{MC}$ sobre o passado. Ou sobre o presente? Que pretende MC com este final? É possível que uma tal ironia seja mesmo reflexo da perplexidade que, a respeito do descalabro que atingiu o poderoso império romano, o próprio Mário de Carvalho afirma sentir, em entrevista à revista Ler, n. 34 (Primavera 1996:46):

Quando escrevo um livro sobre a Lusitânia Romana - Um deus passeando ... -, deve ser claro para o leitor que estou a pensar nos dias de hoje, sem com isso procurar fazer um paralelismo estrito, que as situações não são comparáveis. Essa inquietação minha está lá. Alguma coisa na queda do Império Romano me incomoda. Porque eu percebo mal. Sei que há bibliotecas sobre o assunto, mas não percebo muito bem.

Eis aqui, claramente enunciado, um dos objetivos que presidem ao romance histórico contemporâneo: reavaliar o presente através do passado. ${ }^{18}$ Osvaldo Silvestre (1998:219) observou-o muito bem na fina análise que fez a esta obra (e à obra) de Mário de Carvalho:

Como sucede com a ficção científica, também neste caso o romance histórico é, e aliás sempre foi, uma forma de abordar questóes de hoje: e nada como reflectir sobre o mais bárbaro dos séculos (o nosso) a partir de situaçôes históricas em que os bárbaros se encontram às portas da Cidade (quando não a governam, por desencontradas razóes de hereditariedade ou conspiração política).

Mas este romance não é histórico, adverte o autor logo de início. Não será "histórico" no estrito sentido da palavra, pois Tarcisis, a cidade lusitana onde se desenrolam os principais acontecimentos, na verdade nunca existiu;

18 É, segundo M. F. Marinho (1996:258), um "novo modo de encarar o material histórico e de o transformar em discurso literário que o aproxima daquilo que Linda Hutcheon chama de metaficção historiográfica pós-moderna”. 
mas a presença constante de um conjunto de referentes e indícios epocais convidam-nos a considerar que o quadro foi ficcionado como se fosse real. As alusôes a eventos ou figuras datáveis remetem para um tempo da acção situável no ano de 175 d. C., o ano da conspiração de Avídio Cássio, no tempo do imperador Marco Aurélio. Esta data é apresentada ao leitor, a abrir o capítulo II, da seguinte forma:

Aos 213 anos da era de Augusto, 928 da fundação da Urbe, sob o império de Marco Aurélio Antonino, [...].

Uma tal forma de datação não é hoje facilmente inteligível, mas, sendo o narrador um romano, de que outro modo poderia ele datar os acontecimentos? Com semelhante preocupação de rigor - ou antes, de verosimilhança -, o autor bem pode afiançar que o romance não é histórico; a verdade é que fez tudo o que era devido a um romance de cariz histórico, investigando a fundo a época em que situou o romance. O próprio Mário de Carvalho afirmou, na já referida entrevista à Ler (1996:48):

Para Um deus passeando ..., eu li tudo o que tinha à mão sobre aquela época. Muitos dos pequenos episódios que aparecem no livro são tirados de livros clássicos. [...] Tive também a preocupação de usar o vocabulário adequado, às vezes com a necessidade de importar palavras directamente do latim. Estou a lembrar-me da palavra "pormério", que é o espaço sagrado em volta da Cidade, que separa as últimas casa das muralhas. Não há palavra portuguesa para isso. E há a palavra «janitor», o homem que guarda as portas. Preferi não usar o "guarda-portáo» e importei do latim, porque quis utilizar o vocabulário preciso. [...] Praticamente todas as palavras e frases desse livro foram passadas por uma peneira. ou para serem rejeitadas, ou para serem alteradas, ou para serem assumidas.

Ou, como disse o autor em entrevista a Carla Ferreira (2003:47), que lhe perguntava como se documentou para escrever o romance:

Derrubei uma biblioteca. Li tudo o que tinha à mão sobre esse período da história romana.

Estas observaçóes poderiam ser ilustradas com uma longuíssima lista de achados línguísticos propostos pelo autor. Se se pretendesse fazer um 
catálogo dos termos "importados do latim", isto é, dos termos latinos aportuguesados, que ocorrem em Um deus passeando pela brisa da tarde, esse elenco não teria fim. Refiram-se apenas alguns, relativos à vida quotidiana, que já encontrámos em Quatrocentos mil sestércios: villa (assim mesmo, em latim), vílico, lucerna, lares (deuses), larário, cubiculo (quarto), ancila (escrava), jovens togados e pretexta, cúria, toga cândida (a toga branqueada do candidato às magistraturas), espórtula, ostiário (porteiro), agro (campo), ópido (cidade fortificada), ditador (na acepção de magistrado único), lictores, vélites (soldado armado à ligeira), impedimenta (bagagem militar), e ainda reciário, mirmilão, auriga, cavalos funales (cavalos de tiro), spina, lanista (mestre de gladiadores), todos eles termos da linguagem técnica dos jogos circenses. Luísa Costa Gomes fala de uma reconstituição histórica que «é tão meticulosa que, em sítios, chega a ser especiosa» e fala igualmente de "verosimilhança linguística», afirmando que ela "é de tal ordem que nunca paramos para nos perguntar se aquela palavra existiria no século III (sic)». ${ }^{19}$ Essa verosimilhança ou plausibilidade reflecte-se também numa fraseologia que dá tom romano ao texto. Assim: "Marco Aurélio viveu" (p. 13), forma romana de dizer que Marco Aurélio já tinha morrido; ou: "restabeleceu-se a ordem do Senado e do Povo Romano" (17), numa evocação do Senatus Populusque Romanus, designação do estado romano vulgarizado na conhecida sigla S.P.Q.R.

Bem mais significativo é o exemplo que se segue. Logo na magistral abertura do romance, o narrador surge a evocar o exemplo de alguém que noutros tempos passou por idêntica situação:

Também a mim, como ao Orador, amarga o ócio, quando o negócio foi proibido.

Trata-se de uma alusão clara a Cícero - político e orador eminente -, que várias vezes teve de se afastar do negotium, isto é, da vida pública da política, e se viu forçado, a contragosto, a retirar-se para as suas villae e a dedicar-se à vida de otium, o otium com dignitate, que nele consistia em

19 Cit. de http://www.livarcoiris.pt/biena1198/Bibliografia/paginas/m_carvalho. html.p.4. Os exemplos aduzidos ilustram bem duas qualidades notáveis da escrita de MC, "um saboroso domínio da língua" e uma "natural inventiva vocabular", conforme escreveu J. Colaço (1995 s.u.). 
dedicar-se à reflexão filosófica, às letras e à escrita. ${ }^{20}$ Assim o ex-duúnviro Lúcio, afastado da política e retirado na sua villa, justifica a sua situação presente, pois, tal como o Orador, também ele se vai dedicar ao otium da escrita, registando para a posteridade o que se passou nos tempos do seu duunvirato.

A par de processos deste teor, MC sustentou a verosimilhança dos diálogos e da linguagem socorrendo-se de textos clássicos, que tão bem conhecia. Como ele mesmo assevera, em entrevista a Rosana dos Santos (2009: 264): "As falas de Marco Aurélio, em Um deus passeando pela brisa da tarde, são praticamente todas dos Pensamentos para mim próprio, de acordo com a edição portuguesa, da editorial Estampa.”

Compreendem-se, pois, as palavras proferidas pelo autor na cerimónia com que a APE galardoou o romance Um deus passeando pela brisa da tarde: na hora de receber o prémio, Mário de Carvalho evocou as longas horas de luta com as palavras, a pesar umas e outras, e chegou mesmo a afirmar - "num arroubo de irónica acribia filológica" (comenta Osvaldo Silvestre, no artigo já referido) - que "o ideal seria ter escrito o livro em latim. Mas desconfio de que o meu editor náo seria muito receptivo a essa proposta".

Nem o editor nem o leitor, evidentemente...

E com esta "boutade", ou piada, voltamos a uma das impossibilidades do romance pós-moderno e do romance de Mário de Carvalho. Ela exprimirá o mal-estar de quem sabe que a reconstituição do passado é na realidade impossível e que, desejando a todo o custo náo ficar muito distante dela, tentou sistematicamente criar um clima de verosimilhança e evitar anacronismos e impropriedades nos registos histórico e línguístico. Desta forma, Mário de Carvalho, aquele de quem se disse que é "um leitor voraz, o que faz dele um escritor culto, perfil não táo frequente como isso na nossa literatura", ${ }^{21}$ conseguiu, com a sua grande bagagem clássica, prender o leitor, que aceitou o desafio de se deixar transportar a outros tempos, mantendo embora o pé no presente, e vendo nesse passado, como $\mathrm{MC}$, sinais do futuro.

20 Sobre os conceitos de otium e negotium e a sua relevância moral e política no seio da sociedade romana, e em particular em Cícero, veja-se Pereira (1984: 379-388).

21 Silvestre 1998: 224. 


\section{Cultura Clássica em Um deus passeando pela brisa da tarde de Mário de Carvalho}

António Manuel Gonçalves Mendes

Universidade de Aveiro 
(Página deixada propositadamente em branco) 
Forçado ao exílio pela cidade que havia servido com extrema dedicação, Lúcio Valério Quíncio vive agora um amargo ócio longe dos afazeres da governação. Nesta como em outras situaçóes da vida, este é o preço a pagar pela incompreensão e pela inveja.

Protagonista do romance Um Deus Passeando pela Brisa da Tarde ${ }^{1}$, Lúcio foi duúnviro por duas vezes numa cidade do sul da Hispânia, na região da Lusitânia, de nome Tarcisis, nos tempos do Imperador Marco Aurélio (121-180 d.C.). Este morrera entretanto, e, no capítulo I, aparece-nos um Lúcio profundamente desencantado, remetendo-nos para aquilo que "se adivinha ser um começo «in ultimas res» da matéria que vai seguir-se" 2 e que acontece, pelo menos em parte, no Império do seu filho Cómodo (161-192 d.C.).

O romance desenvolve-se sobre dois alicerces fundamentais: por um lado, a figura mítica do imperador-filósofo, Marco Aurélio, intimamente ligada à figura de Lúcio; por outro, a expansáo do cristianismo por todas as regióes do Império, de que Tarcisis não é excepção. A ligação entre estes dois pontos é feita através do desenvolvimento da história de amor entre Lúcio, magistrado do Império, e Iunia Cantaber, uma patrícia convertida ao cristianismo.

É, curiosamente, essa paixão de Lúcio por Iunia - um, representante da romanidade, outro, pertencente a uma "seita" atentatória desses valores, crente no Deus único - é essa paixão, dizia que o lança para fora da cidade, para a sua antiga uilla que havia sido destruída e maculada por hordas de bárbaros esfomeados.

Personagem-narrador, Lúcio, na sua primeira aparição no início do romance, sofre pelo desterro, pelo sentimento de inutilidade em que se vê, obviado, apenas, pela leitura, pelo consolo dos clássicos:

Brilha o céu, tarda a noite, o tempo é lerdo, a vida baça, o gesto flácido. Debaixo de sombras irisadas, leio e releio os meus livros, passeio, rememoro, devaneio, pasmo, bocejo dormito, deixo-me envelhecer. Não consigo comprazer-me desta mediocridade dourada, pese o convite e o consolo do poeta que a acolheu. Também a mim, como ao Orador, amarga o ócio, quando o negócio foi proibido.

* Este artigo corresponde, no essencial, ao publicado nas Actas do III Colóquio Clássico, realizado na Universidade de Aveiro, nos dias 22 e 23 de Abril de 1999, sob a coordenação de João Manuel Nunes Torrão.

${ }^{1}$ Carvalho ${ }^{4} 1996$. Todas as citações serão feitas a partir desta edição.

2 Seixo 1995. 
Os dias arrastam-se, Marco Aurélio viveu, Cómodo impera, passei o que passei, peno longe, como ser feliz? (13).

Lúcio vive numa aparente quietação, que não é mais do que o otium clássico, propiciador da Humanitas. Proibido de exercer o negotium, aproveita, pelo menos, para possibilitar ao espírito a disponibilidade para se entregar à reflexão, à meditação ${ }^{3}$, bem de acordo com o princípio horaciano da aurea mediocritas ${ }^{4}$. No princípio do romance, porém, a um fim de tarde agradável corresponde um narrador envelhecido, marcado pela monotonia, procurando, de novo, ser feliz.

\section{Do estoicismo de Lúcio}

Há, portanto, um firme propósito de recuperar um estado de espírito de tranquilidade interior, de moderação e do completo domínio de si próprio, de acordo com os preceitos do estoicismo. Lúcio confessa, aliás, a sua simpatia por esta corrente filosófica, quando, no capítulo XVIII, perante o facto de ter de julgar o grupo de cristáos, onde pontifica Iunia, sua apaixonada, e depois de equacionar o suicídio, declara:

Iria eu atraiçoar derradeiramente o lema de Epicteto que sempre quisera - com tanto insucesso - adoptar como norma de vida: «tem-te! Aguenta!» (287).

Nesta fórmula - sustine et abstine - que Aulo Gélio 5 atribui a Epicteto, resume-se a doutrina moral dos Estóicos.

Por outras palavras, o ideal do sábio estóico consiste em ter completo domínio de si, ser autosuficiente (autárcheia); atingir um estado de imperturbabilidade, a apátheia ('apatia'), que é condiçâo indispensável para lograr a serenidade da alma e a liberdade, características do sábio e base da sua felicidade; e evitar a dor, a ataraxía, conceito no qual se consubstancia

3 Cf. Buescu 1979: 42.

4 Horácio, Carmina 2.10.5-8: Auream quisquis mediocritatem/ diligit, tutus caret obsoleti/sordibus tecti, caret inuidendal sobrius aula.

5 Aulo Gélio, Noct. Att. 17.19.6: «Itaque, inquit, si quis haec duo uerba cordi habeat eaque sibi imperando atque obseruando curet, is erit pleraque inpeccabilis uitamque uiuet tranquillissimam». Verba duo haec dicebat: $\alpha$ vé $\chi \omega$ et $\alpha \dot{\pi} \chi \varepsilon_{\chi} \omega$. 
a essência da felicidade e que consiste em manter-se impassível perante os sofrimentos físicos e morais, as enfermidades, a morte, os bens da fortuna, as opinióes dos homens... Estas são as bases da vida virtuosa e feliz. A este propósito diz Marco Aurélio nas Meditaçôes ${ }^{6}$ :

Hás-de ser como uma rocha contra a qual nada podem as ondas todas do mar. Ela está firme e o mar acalma-se em volta dela.

Como exemplo desta corrente filosófica, Marco Aurélio está presente em vários momentos da obra. É o Imperador, o Príncipe e também filósofo, modelo a seguir por todos os magistrados. É o que diz Lúcio ao seu centuriáo Aulo:

Este é o divino Marco Aurélio Antonino, meu e teu senhor. Imaginas o Imperador a perseguir os que lhe atiram epigramas, os que intrigam no palácio, ou os que discordam dele? Marco Aurélio é um filósofo e vive rodeado de filósofos, quando as circunstâncias o não forçam a vestir o elmo e a couraça. O seu procedimento e a sua figura devem iluminar os actos de todos os magistrados do Império, porque são a imagem da moderação e da justiça (100-101).

Dez anos antes de ser duúnviro, Lúcio Valério, ainda jovem, integrou uma delegaçáo de Tarcisis a Roma, a fim de agradecer ao Imperador um donativo de um milhão de sestércios gastos no restauro do forum, das termas e dos templos. Essa estadia coincidiu com o terceiro aniversário do jovem príncipe Lúcio Antonino Cómodo. Enquanto aguardavam ser recebidos pelo Imperador, puderam assistir aos jogos celebrados no Circo Máximo. Lúcio, completamente avesso a estes divertimentos, não apostou nas corridas, notando que o Imperador também não era grande amante destas competiçôes, pois não lhes dispensava muita atenção. A delegação foi, entretanto, recebida e, cumpridas as formalidades protocolares, Marco Aurélio chamou Lúcio pelos seus tria nomina. Disse-lhe que não o vira apostar, deduzindo que ele não gostava daqueles espectáculos, mas fez-lhe uma advertência em tom de conselho que, se viesse a ser seguida por Lúcio, evitaria dissabores no exercício das suas funçóes:

As coisas são como são, Lúcio Quíncio. Suporta-as e abstém-te da indignação. Não se pode impor a cada cidadão um filósofo e seguir-

6 Marco Aurélio, Meditaçōes 4.49. 
-lhe todos os passos. E, sendo, pelo que sei, um jovem promissor na tua cidade, nunca demonstres, por actos ou omissôes, que estás longe do sentir do povo. Poderias romper um equilíbrio fixado na ordem natural das coisas em que as tuas convicçóes interviriam como um mero capricho pessoal, alheio e perturbador (187).

E, um pouco mais adiante, deu-lhe mais um conselho:

Um outro dever do homem público é saber tudo o que se passa à sua volta. Não te esqueças (187).

Lúcio ou não compreendeu ou não quis desviar-se do curso harmonioso de uma vida que se manteve igual a si mesma (recta ratio), não pondo, por isso, em prática os conselhos do Príncipe. Não abdicou de viver segundo a sua natureza, de acordo com a sua opção filosófica, ainda que no exercício da magistratura, deixando para segundo plano o sentir do povo.

Daí a incompreensão, o distanciamento, e até a desilusão que a personalidade de Marco Aurélio provocou na personagem, quando o tribuno Marco Agneio Scauro, chefe das três coortes da VII Legiáo Gémina, estacionada perto das muralhas de Tarcisis, lhe mandou cópia de um édito do Imperador, que obrigava a perseguir todos os cristáos, por os considerar inimigos naturais do império:

Na minha frente, o busto de Marco Aurélio Antonino quase sorria, de olhos levantados ao alto. Pedra, gelado mármore, a contemplar a posteridade, desatento de mim e das minhas súplicas. Como podia um homem táo clemente, tấo ciente da relatividade das coisas e das opinióes, publicar normas assim inflexíveis e arbitrárias? Por que perseguir os cristáos, mais que os mitraicos, os de Cibele, os de Ísis, os de Sóstrato, os Judeus? (...) Por que havia um soberano que eu respeitava e venerava de querer fazer mal a Iunia Cantaber?

Apeteceu-me apostrofar as imagens do Imperador. Voltá-las contra a parede. Retirá-las do meu larário (285).

E, no fim do romance, é indiferente à morte do Imperador:

Desapareceu, por fim, Marco Aurélio Antonino e eu não verti uma lágrima (319). 
Lúcio é fiel aos ideais estóicos, quando, por ocasiāo do seu aniversário, Airhan lhe dá a notícia de que os Mouros passaram o Estreito. Pensativo por uns instantes, resolve dar uma volta por Tarcisis para ver se tudo está bem. Tem uma primeira sensação de estranheza, face à sua cidade, ocupado que andava com o exercício da magistratura:

Cidade afinal estranha, aquela. $\mathrm{Na}$ verdade eu, que todos os dias atravessava Tarcisis e decidia sobre os destinos de Tarcisis, acabava por descobrir que não conhecia a minha cidade... (61).

Mais tarde, quando o senador Calpúrnio lhe chama a atençáo para o seu descuido em relação ao povo, não lhe oferecendo jogos, recorda e nota as palavras coincidentes com os conselhos recebidos dez anos antes, da boca do Imperador:

O que me inquietava, no meu regresso, era perceber que no fundo, os conselhos do senador hispânico Énio Calpúrnio coincidiam, bem vistas as coisas, quase ponto por ponto, com as observações do filósofo Marco Aurélio, dez anos antes...(196).

Como alguém que cai na realidade, que pretende confirmar as acusaçóes de que andava, de facto, alheado do eleitorado, chega a casa nessa noite e pergunta à esposa quem tinha ganho as corridas no Circo Máximo de Roma e o nome do auriga da moda. Mara a tudo responde e a pergunta admirada impóe-se:

- Como sabes, Mara?

- Toda a gente sabe, Lúcio (200).

Mara vai ainda mais longe, ao relatar ao marido que Cornélio Lúculo, um poetastro que tinha sido encontrado morto há algum tempo, enviava poemas a Galla, mulher do centurião, às escondidas, pedindo-lhe encontros. Lúcio, estupefacto, questiona-se sobre se Aulo saberia. Ao que ela responde:

Em Tarcisis toda a gente sabe sempre tudo. Excepto tu, Lúcio Valério...(268).

Um outro aspecto, em que podemos analisar o posicionamento filosófico de Lúcio prende-se com uma ida às termas. Não que precisasse de fazer 
tratamentos, mas táo só para falar com Calpúrnio acerca da necessidade de demolição da casa de Pôncio Módio.

Calpúrnio justifica a sua presença ali, pelas propriedades medicinais das águas:

Hás-de estranhar, ver-me nas termas públicas... O meu médico entende que estas águas são melhores para o sangue. Desde que evite o frigidário, claro...(84).

De facto, deve-se à chegada a Roma de médicos gregos, com uma medicina baseada em métodos científicos, uma utilizaçáo séria e racional das águas. Para a difusão da moda das águas, contribuiu também o influxo do helenismo que havia divulgado na Cidade, juntamente com um ideal de vida muito mais luxuoso que o tradicional, os benefícios para a saúde das curas termais.

É precisamente na época em que se situa o nosso romance, Época imperial que a hidroterapia atinge o seu maior esplendor, ao ser praticada tanto por indivíduos sáos como por doentes. O elevado número dos balnea por todos os pontos do Império Romano demonstra bem como a hidroterapia alcançara uma verdadeira função social: todos frequentavam as termas, fosse qual fosse a época do ano ${ }^{8}$.

Disso nos dá conta o narrador que, antes de entrar nas termas, prevê o ambiente que o espera:

Sabia que ia encontrar nos banhos uma leviandade alegre e despreocupada que fazia contraste com os árduos trabalhos que agora se iniciavam. Era capaz de apostar que a maioria dos da minha cúria, tấo ocupados, achacados e indisponíveis quando se tratava da coisa pública, se encontravam a tagarelar à borda das piscinas (82).

Com esta nota de ironia, Lúcio denuncia a irresponsabilidade de todos os seus colegas, face aos perigos de um iminente ataque dos bárbaros. Por outro lado, remete para o ambiente de certa promiscuidade nos banhos:

7 Sobre as termas, e para informações mais detalhadas, vide Guillén 1977: 329-339; Carcopino 1993: 320-330.

8 Usamos, com a devida vénia, ideias de Carlos Alberto Louro Fonseca, expressas em aulas de seminário e facultadas em apontamentos manuscritos. 
Havia quem, possuindo balneário, nunca aquecesse as fornalhas do hipocausto e preferisse a promiscuidade das termas públicas, ou por uma questáo de avareza ou por apego à convivência (82).

Ecos destas palavras são-nos dados por Marcial que descreve Baias, a mais famosa estância termal da Antiguidade, como sendo o "litoral dou-

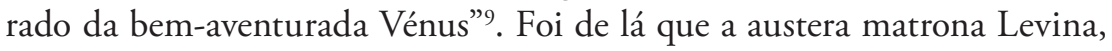
anteriormente uma Penélope, regressara a casa uma Helena, ao abandonar o marido para seguir um jovem por quem se apaixonara ${ }^{10}$. Assim, a vida descuidada e mundana que aí se levava, se, por um lado, tinha um efeito físico e psicológico benéfico sobre aqueles que lá estanciavam, por outro, criava atitudes de rejeição nas pessoas com uma conduta moral mais preconceituosa.

Séneca, filósofo estóico, aconselhava a desviar os próprios passos de um tal lugar, em que a moral corria sérios perigos ${ }^{11}$. Quando descreve ao pormenor o ruído de umas termas vizinhas, o filósofo prefere ignorá-lo, como se fosse algo pouco importante:

Mas, por Hércules, eu não quero saber mais deste frémito do que das ondas ou de uma queda de água... ${ }^{12}$

Desta forma, compreendemos melhor o pouco à-vontade e até a celeridade de Lúcio Quíncio ao entrar nos banhos públicos de Tarcisis:

Não deixei que me vestissem, passei pelo caldário, entre sombras que se moviam preguiçosamente e entrei, de toga, no tepidário, àquela hora apinhado de gente (82).

Queremos, assim, sublinhar o espírito determinado de Lúcio na defesa da sua cidade, contra os inimigos exteriores, não conseguindo, porém,

9 Marcial, Epigramas 11.80.1-2: Litus beatae Veneris aureum Baias / Baias superbae blanda dona Naturae.

10 Marcial, Epigramas 1. 62. 5-6: incidit in flammas: iunenemque secuta relicto / coniuge Penelope uenit, abit Helene.

11 Séneca, Cartas, 5.51.3: Itaque de secessu cogitans numquam Canopum eliget, quamuis neminem Canopus esse frugi uetet, ne Baias quidem: deuersorium uitiorum esse coeperunt. Tradução de Segurado e Campos (1991).

12 Séneca, Cartas a Lucílio, 6.56. 3. Tradução de Rocha Pereira 1994: 228. Vide também Segurado e Campos 1991: 191. 
livrar-se dos inimigos internos, unidos em torno do liberto e candidato a edil, Rufo Glicínio Cardílio. Por outras razões, esses são os mesmos inimigos dos cristáos, onde se destaca Iunia, que como já referi, exerce, desde a primeira hora um profundo fascínio em Lúcio.

\section{Da simbologia dos peixes e das rosas}

Por razões óbvias, o peixe é um elemento presente, desde o princípio até ao fim da história. Sendo os cristãos o grupo catalisador da acção, é lógico que o peixe, um dos símbolos do cristianismo, esteja presente como marca distintiva e de afirmação desse mesmo grupo. A explicação, pelo menos em parte, dessa simbologia é fornecida por Iunia, numa conversa com Lúcio:

- (...) E esse peixe que vocês por aí pintam, o que é?

- Ichtús!

— Eu sei, também falo grego.

- Didacticamente, com uma paciência afectada, explicou-me, a partir das iniciais do vocábulo, que se tratava de um anagrama para Jesus Cristo Filho do Deus Salvador (137).

A palavra grega ixĐúc ('peixe’) foi, portanto, tomada pelos cristãos como um ideograma em que cada uma das cinco letras era vista como a

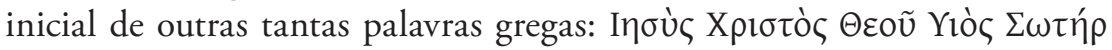
('Jesus Cristo, filho de Deus, Salvador'). Daí as numerosas representaçôes simbólicas do peixe nos antigos monumentos cristãos, nomeadamente funerários ${ }^{13}$. Daí também, e agora já no plano da história, as múltiplas pinturas de peixes, que progressivamente aparecem pelas ruas de Tarcisis:

À minha passagem, notei, em várias paredes, grafitos que representavam um peixe e concluí que a seita adoradora de peixes estava a expandir-se na cidade (109).

Essas pinturas vão aparecer em cima do material de campanha eleitoral do candidato a edil, provocando desde logo uma fractura entre o poder político e o novo grupo religioso, para além de queixas formais ao duúnviro:

13 Chevalier, G.1994: 515-516. 
Um tal Dafino (...) explicou prolixamente que vinham em protesto pedir a minha intervençáo que. Alguém tinha desenhado um peixe sobre os grafitos eleitorais de Rufo Cardílio, o, sobre ser uma afronta ao próprio, assinalava ainda desrespeito ímpio pelas leis e pelos costumes de Roma e da cidade (109-110).

A partir daqui, a fractura acentua-se, a ponto de Lúcio receber uma mensagem anónima com um peixe recortado em couro, que denunciava rituais obscenos, praticados em casa do seu amigo Máximo Sálvio Cantaber. Deste modo, o peixe está lançado no caminho do magistrado: primeiro, porque lhe compete fazer algo para impedir a expansão dessa seita; depois, porque, ao fazer algo, vai ter que se confrontar com Iunia, cabeça do grupo.

A este propósito há um episódio, bastante elucidativo: um dia, Lúcio recebe em sua casa um lúcio (lucius), isto é, um peixe enorme, acompanhado de um saco de favas. Este presente 'envenenado' tinha sido deixado por alguém à entrada da porta. Lúcio não consegue disfarçar alguma apreensão:

Por mais que eu quisesse esquecer-me, ou deixar os cristáos para depois, havia sempre alguém que mos vinha lembrar. Desta vez, através de um simbolismo especioso: um peixe portador do meu nome, devastador e canibal, que engole tudo o que é vivo em volta e que uma vez à solta, é a ruína das lagoas e dos viveiros. E aquele sinal funério das favas...(120-121).

Este sinal premonitório de morte - as favas são símbolo dos mortos e ao mesmo tempo da sua prosperidade ${ }^{14}$ - anuncia desgraça, tragédia. Primeiramente sobre a família de Iunia, depois, pelo menos em parte, sobre Lúcio, que se sente cada vez mais fascinado pela patrícia convertida ao cristianismo, a ponto de, certa vez, ao presidir ao tribunal, dar por si a desenhar um peixe nas tábuas de cera...(140).

Lúcio não pensa converter-se ao cristianismo. Está, antes, rendido a Iunia. Há muito tempo. Quando resolve ir à casa de Máximo falar sobre a denúncia de rituais obscenos, que anonimamente recebeu, dá-se o primeiro encontro entre eles. Não falam, apenas se olham. Lúcio não fica indiferente:

Nessa altura, uma mulher de túnica azul-clara, pregueada à grega, voltou-se na minha direcção. Não sei que impulso foi aquele, se pro-

14 Chevalier, Gheerbrant 1994: 317. 
vocado por uma espontânea impaciência, se por qualquer ruído que, sem querer tivesse produzido. Ao movimento, o sol, passando-lhe nos olhos, de um verde muito esbatido, quase os iluminou num relance brevíssimo. Ela fitou-me por um instante e eu desviei o olhar. (...) Os olhos, quase transparentes àquela luz, dilataram-se, súbitos, e seguiram os meus (128).

A cor dos olhos de Iunia não é inocente. $\mathrm{O}$ verde remete para o reino vegetal, para a natureza, para o despertar da vida, daí a autenticidade com que se apresenta. Para além disso, o verde entra com o vermelho num jogo simbólico de alternâncias. A rosa floresce entre folhas verdes. E é precisamente uma rosa que Clélia, a irmã mais nova de Iunia, deixa dependurada num ramo alto, sob o qual Lúcio e seu pai conversam.

A rosa que ela tinha colocado na árvore caíra sobre o banco de mármore, como um borrão vermelho brilhante, a desfeitar a lisura monótona da pedra...(134).

Aquela rosa, símbolo da atracção por Iunia, eis que se transforma em borrão. Tal como a relaçáo entre os dois, pelo menos a médio prazo.

$\mathrm{Na}$ cidade, a oposição ao grupo de cristãos é cada vez maior. No forum, mais um ajuntamento em torno de Rufo, que arengava, denunciando a pérfida seita, ao mesmo tempo que alguém agitava um cartaz de madeira representando um peixe a debater-se, trespassado por um tridente (157).

Entretanto, mataram os cães a Máximo e Lúcio vê-se compelido a falar com Iunia. Nesse encontro, de novo em casa dela, o magistrado encontra-a no jardim, onde roseiras caóticas que misturam pétalas murchas com pétalas vivas trepavam pelas colunas...(159).

Esta ideia de caos, que é referido numa dimensão exterior, é o reflexo do interior de Lúcio. Contra os seus princípios filosóficos, ele sente-se perturbado pela paixáo:

Logo que vi Iunia, senti estranhamente um baque, uma espécie de sobressalto como se o peito se me contraísse, e esqueci tudo o resto, mesmo a culpa que me moía por ter abandonado as minhas obrigaçóes para comparecer em frente dela (159-160).

É Iunia, apesar do acolhimento frio, que inicia a conversa, desviando-a, no dizer do narrador, para banalidades irritantes: 
Como as rosas tinham crescido em táo pouco tempo, como as noites eram frias em Tarcisis... (160).

Sem querer, Iunia sintetiza a situação: a atracção cresceu em pouco tempo, mas o clima, a conjuntura, constituíam um obstáculo ao seu desenvolvimento. Estes sinais, como que a antecipar o futuro, vêm a confirmar-se.

Quanto às paixões, mais vale não só dominá-las e submetê-las à razão, como até extirpá-las, preconiza o racionalismo moral do estoicismo.

Assim, bem perto do desenlace da intriga, quando Lúcio se viu obrigado a julgar o grupo dos cristãos, eis que o vemos, na véspera do julgamento, em actividades caseiras de relaxe:

Durante quase todo o dia dediquei-me a não fazer nada ou a actividades absolutamente fúteis, como as de transferir peixinhos dourados, raros, do tanque do peristilo para o implúvio ou podar as roseiras do jardim. Nestas tarefas, Mara ajudou-me, com uma alegria fantasiada, por de mais excessiva...(296).

Embora referidas como actividades absolutamente fúteis, estas actividades tinham de ser feitas. Transferir peixinhos e podar rosas são acçōes que carregam uma profunda marca simbólica: como que antecipando o julgamento, os peixinhos, isto é, os cristãos, ou reafirmam a fé e são enviados para Roma para serem condenados à morte (é o que acontece a Iunia), ou a renegam e têm de fazer uma libação à estátua de Júpiter (é o que acontece a todos os outros, Mílquion incluído). $\mathrm{O}$ podar as rosas, na companhia da sua esposa, simboliza a determinação de Lúcio em respeitar a instituição do casamento, em preservar o afecto, o amor em relação a Mara, libertando-o de tudo aquilo que era inútil, que o desfeitava. Só assim ele podia alcançar a imperturbabilidade (apátheia), condição indispensável para atingir a serenidade e ser feliz.

Mara, companheira fiel e cúmplice desta determinação, está alegre. E, para finalizar este dia vivido a dois, escolhe a leitura para antes do adormecer: um trecho do Satyricon ${ }^{15}$ :

15 Petrónio, Satyricon 3.10.: ... sic eloquentiae magistri tamquam piscator, qui nisi eam imposuerit hamis escam quam scierit appetituros esse pisciculos, sine spe praedae moratur in scopulo. (Seguimos a lição de Ernout $\left({ }^{11} 1993\right)$ para o texto latino e usamos a tradução portuguesa de Leão: 2005). 
O mesmo se passa com o mestre de eloquência: se não seguir o exemplo do pescador que coloca na ponta do anzol a isca que sabe que vai atrair os peixitos, lá fica especado no seu rochedo, sem esperança de pescaria.

Bem a propósito este conselho para o duúnviro que, no dia seguinte, qual pescador, vai usar o engodo que sabe ser apreciado pelos ouvintes, ou seja, vai, por fim, satisfazer a vontade dos seus detractores políticos, personificados em Rufo Cardílio, julgando os cristáos. Vai, finalmente, julgar Iunia, que há muito o reclamava, como, aliás se pode comprovar pelas palavras do narrador: ... quando pronunciei a condenação de Iunia à morte (...) olhou para mim, com uma expressão de felicidade triunfal. Nunca lhe tinha visto tanta alegria no rosto (313). Lúcio, por seu turno, liberta-se, finalmente, de uma perturbadora paixão.

É a hora das despedidas. Iunia parte para Roma, Scauro parte com a VII Legião Gémina, Lúcio é aconselhado a partir, pois a sua permanência no duunvirato era malvista por muita gente (316).

E sempre com a mesma determinação, procurando alcançar alguma serenidade perdida, Lúcio resigna ao seu cargo, com a plena sensação do dever cumprido. Preferiu não se despedir de Iunia. Os seus concidadáos preferiram também náo se despedir dele. E lá regressa ao campo, para reconstruir a uilla paterna, reconstruindo uma nova vida. Quanto aos cristãos são fumos fátuos de um lume de palha (319), embora o tenha inquietado, numa das suas deambulaçóes pelo campo, um pequeno escravo que desenhava um peixe na areia.

Pisoteei meticulosamente o desenho com as minhas botinas cardadas...(...). Acto inútil. Não se apagam as realidades destruindo-lhes os símbolos (19).

Neste regresso às origens, longe das intrigas políticas, Lúcio reafirma a fidelidade aos valores da romanidade:

Deixem-me cultivar esta despreocupaçáo, a ilusão de que o mundo seguirá para sempre imperturbado e imperturbável...(...). Sou um senhor da terra, sou um romano, leio, cultivo-me, marco os tempos com o meu porte, (...) o meu trajo togado. Dignidade. Gravidade. Romanidade. Humanidade (16). 
Eis a profissão de fé: imperturbabilidade (apátheia), dignitas, grauitas, Humanitas.

"Como é próprio do Humanismo, o romance postula a perenidade dos valores e sobretudo das inquietaçôes (éticas ou metafísicas) e a contemporaneidade dos Antigos ${ }^{16}$. E, ainda que o autor, numa nota paratextual, avise que este não é um romance histórico ${ }^{17}$, talvez isso seja um apelo a abordarmos, a partir do romance, questôes da actualidade: "e nada - conclui Osvaldo Silvestre - como reflectir sobre o mais bárbaro dos séculos (o nosso) a partir de situaçóes históricas em que bárbaros se encontram às portas da Cidade (quando não a governam, por desencontradas razóes de hereditariedade ou conspiração política)"18.

Em finais do século xx, em que não faltam Rufos Cardílios passeando-se em resplandecentes togas cândidas, ter valores e ser-lhes fiel é uma aprendizagem (ou reaprendizagem) que podemos fazer com os Clássicos. Eis a resposta para quem se continua a perguntar: 'E para que servem, hoje, os Clássicos?’

16 Silvestre 1998: 223

17 Carvalho 1996: 11. Esta nota, em jeito de advertência, aparece antes do capítulo I: «Este não é um romance histórico. Tarcisis, ou, mais propriamente, o município de Fortunata Ara Iulia Tarcisis, nunca existiu». A propósito do conceito de História e suas implicaçóes na obra de Mário de Carvalho, veja-se o artigo de Marinho 1996: 257-267.

18 Silvestre 1998: 219. 
(Página deixada propositadamente em branco) 


\title{
O lado errado do Marenostro: o elemento mouro como símbolo de alteridade e barbárie em \\ Um deus passeando pela brisa da tarde
}

\author{
Carla Carvalho Alves \\ Pesquisadora de pós-doutorado da USP \\ Bolsista da FAPESP
}


(Página deixada propositadamente em branco) 
O título desse artigo provém de um diálogo contido na obra de Mário de Carvalho, Um deus passeando pela brisa da tarde, no qual se discute a invasáo dos mouros a uma província da Lusitânia. Um dos personagens, ao refletir sobre a origem desses invasores, faz a seguinte colocação: "Tudo a mesma gente: púnicos, mouros... Farinha do mesmo saco. O lado errado do Marenostro." (Carvalho, 1997: 23).

O referido romance de Mário de Carvalho foi publicado pela primeira vez em 1994, sendo contemplado, no ano seguinte, com o Grande Prêmio da Associação Portuguesa de Escritores. Observa-se nessa obra a abordagem histórica, concernente ao II século da Era Cristá, em uma província da Lusitânia, de nome Tarcisis. O caráter histórico da narrativa, entretanto, fica comprometido desde o início do texto, quando se lê uma advertência sobre a inexistência histórica de Tarcisis e a consequente inadequação de Um deus passeando pela brisa da tarde à categoria de romance histórico.

O contexto inicial da obra de Carvalho retrata a condição de desterrado em que se encontrava o duúnviro, Lúcio, no momento em que decide escrever um livro sobre os acontecimentos ocorridos durante sua segunda magistratura. O elemento motivador para essa iniciativa, também aí contemplado, origina-se da visita de Proserpino, outro magistrado de Tarcisis, à villa na qual se refugiaram Lúcio e sua esposa Mara. A presença do antigo colega desperta no anfitrião lembranças de acontecimentos dolorosos, por ele vivenciados. Mesmo que Proserpino, em atitude inesperada, não tivesse mencionado nenhum fato pretérito que pudesse causar constrangimentos, sua simples presença parece ter significado para Lúcio uma referência metonímica representativa de todo o seu passado. A emergência incômoda de recordaçóes ainda pouco remotas para o protagonista ocasiona, dessa forma, a necessidade de sua reconstituição memorial, através da escrita, como se observa nas seguintes palavras de Lúcio: "Pode ser que, escrevendo, se me apazigue o espírito, com manifesta utilidade para mim." (Carvalho, 1997: 26)

Situaçóes relativas aos âmbitos público e privado, vivenciadas por Lúcio, confluiráo ocasionando o já mencionado desterro final do personagem. Os principais problemas políticos enfrentados por ele referem-se à presença de uma nova seita religiosa em Tarcisis - o cristianismo - e à possibilidade de um ataque mouro à cidade. Paralelamente a estas questóes de ordem pública, Lúcio expóe-se a um conflito pessoal ainda mais intenso: a atração inevitável sentida por Iunia Cantaber, representante fervorosa do cristianismo, religião ainda incipiente na Lusitânia, causadora de escândalo e revolta aos cidadãos de sua cidade. 
Acompanha-se, então, ao longo da narrativa, o encaminhar-se do protagonista para um completo isolamento em relação ao povo de Tarcisis, assim como aos outros magistrados e, até mesmo, ao poder supremo de Roma, representado por Marco Aurélio Antonino. Também contribuem para o insucesso de Lúcio seus valores e gostos pessoais, bastante afinados com a cultura literária grega e latina, e totalmente dissonantes em relação aos jogos e espetáculos violentos que entretinham a plebe.

Quando, finalmente, ocorre o cerco dos mouros à Tarcisis, a imagem pública de Lúcio já está bastante desgastada, e quem se configura como o grande herói da situação, salvando inclusive a vida do duúnviro, é seu inimigo Rufo Cardílio. Com a partida dos chamados povos bárbaros, retomam-se as atividades rotineiras da cidade, reorganizando-se um evento que havia sido suspenso devido à situação de instabilidade enfrentada: o julgamento dos cristáos. As conjunturas fazem com que o protagonista seja obrigado a proceder ao julgamento dos religiosos, e a declarar a pena máxima a Iunia Cantaber, o que provavelmente resultaria em sua morte. Segue-se, ainda, o último e fatal abalo à vida pública de Lúcio: a condenação ao exílio.

É a partir dessa ambientação tão singular, e já em si mesma conflituosa, que Lúcio Valério Quíncio, exilado em uma propriedade rural, elabora sua narrativa memorial. Através de sua história, ele vai trançando uma rede de questóes políticas, religiosas e éticas, seguindo sempre uma lógica opositora entre a aparente sensaçáo coletiva de segurança e estabilidade, gerada pela crença em um Império indestrutível, e os reais conflitos e angústias individuais daqueles que, devido às suas insatisfaçóes pessoais, desafiam o que ele chama de "esta mediocridade dourada" (Carvalho, 1997: 13). Os eventos, assim dispostos, pretendem apenas reapresentar a sequência cronológica da narrativa de Um deus passeando pela brisa da tarde, realçando algumas questôes factuais que se articulam, ocasionando o desafortunado destino cumprido por Lúcio Quíncio. A sutil complexidade do romance constitui-se, entretanto, nos interstícios dos fatos aí retratados.

O próprio período histórico abordado, segundo século da Era Cristã, apresenta, a partir de uma perspectiva arguta, presente à elaboração narrativa, uma amostragem interessante de padróes políticos, religiosos, filosóficos e sociais. A imbricação entre paganismo greco-romano, cristianismo, tragicidade e estoicismo, coloca em pauta complexas dicotomias como: indivíduo e coletividade, o homem e a ordem, nómos (lei) e physis (natureza), civilização e barbárie. Embora em todas essas relaçóes possamos perceber afinidades com o tema aqui abordado, interessa-nos, mais especificamente, o último 
par, aparentemente antitético, mas a respeito do qual tentaremos ressaltar a existência de uma relação associativa e inclusiva. Ou seja, o que normalmente é entendido como uma bipolaridade, civilização e barbárie, parece apresentar-se, a partir da presença do elemento mouro em Um deus passeando pela brisa da tarde, como uma situação de interdependência: a barbárie como estrutura intrínseca e necessária ao processo civilizatório romano.

Acompanha-se, no enunciado do romance como um todo, a generalização no tratamento do outro, ou daqueles que não pertencem ao Império Romano: os chamados povos bárbaros. Essa redução da diversidade de alteridades a uma denominação única - bárbaros - pode ser identificada com aquela concepção, proveniente da antiguidade grega, que considerava bárbaros os povos que não falassem grego. Apreende-se, então, ao longo da narrativa que, para os habitantes da Lusitânia, a atribuição da barbárie aos invasores mouros origina-se dos parâmetros civilizacionais atribuídos à romanidade, os quais reduzem a diversidade dos povos não romanos a uma massa uniforme, considerada apenas pela sua diferença em relaçáo ao Império.

Coloca-se, de fato, no romance de Mário de Carvalho uma contraposição entre os mouros invasores e os lusitanos romanos, na qual se expressa uma concepção bastante cristalizada daqueles povos, revelada, de modo mais contundente, através da expressão, anteriormente mencionada: "O lado errado do Marenostro." (Carvalho, 1997: 23). Mas, esse tipo de generalização, feita por um dos personagens, Proserpino, e representativa, também, do pensamento geral dos cidadãos de Tarcisis, mostra-se frágil e imprecisa quando comparada a algumas reflexóes elaboradas pelo protagonista, Lúcio Valério Quíncio, ao contemplar a descrição do ataque mouro à regiáo da Lusitânia.

Se podemos, pois, acompanhar, ao longo do romance, uma interessante discussão relativa à identificação do mouro como bárbaro, devido à divergência entre sua (falta de) cultura e a cultura romana, da qual faz parte o narrador, há, ainda, outra questão, menos explícita, que acaba, também, sendo sugerida no enunciado da obra: a similaridade existente entre as práticas romanas e os rituais bárbaros. Em diversos momentos, a trama conduz a reflexóes sobre uma "cultura bárbara" amplamente difundida e aceita no Império Romano, em suas arenas de gladiadores, no sacrifício dos condenados jogados aos cáes, enfim, nos espetáculos sangrentos que entretinham o povo.

Mas, para além da barbárie associada ao invasor mouro, apresentado como uma alteridade inapreensível e, ainda, daquele contexto, vinculado às 
práticas violentas exercidas no interior do Império Romano, emerge, também, do discurso de Lúcio, outra expressão referente ao âmbito da barbárie. Identificamos, pois, como uma inusitada "invasão bárbara", o sentimento passional de Lúcio por Iunia Cantaber, sendo esta expressão ainda mais devastadora, pois chega a alcançar e desestruturar, até mesmo, as defesas pessoais do protagonista, entâo sustentadas pela racionalidade e moderação estóicas e pelo sentido de civilidade romana.

Apresentaremos, a seguir, mais detalhadamente, cada uma das três referidas elaboraçôes acerca da temática da barbárie, motivadas pela presença moura no discurso memorial de Lúcio Valério Quíncio.

\section{1 - O mouro como representação da alteridade}

O capítulo IX da obra de Mário de Carvalho inicia-se de forma um tanto abrupta com a seguinte frase: "É isto um mouro?" (Carvalho, 1997: 141). A inversão do sentido natural da frase, com o deslocamento do verbo para o seu início, a utilizaçáo do pronome isto, determinando a reificação do mouro, e, ainda, o tom interrogativo da sentença remetem, sem dúvida, ao título da obra de Primo Levi, É isto um homem?. A narrativa de Levi contempla, entretanto, a experiência, em campos de concentraçáo, vivida pelo autor, um judeu italiano, durante a Segunda Guerra mundial. Mas, há um ponto bem evidente, entre outras questôes mais sutis, que discutiremos adiante, que parece indicar, de fato, a relação entre as obras. Como se pode acompanhar abaixo, a seguinte citação apresenta uma colocação bastante cruel sobre o chamado prisioneiro "muçulmano":

No Campo, porém, acontece o contrário. Aqui a luta pela sobrevivência é sem remissão, porque cada qual está só, desesperadamente, cruelmente só. Se um Null Achtzehn vacila, não encontrará quem lhe dê ajuda, e sim quem o derrube de uma vez, porque ninguém tem interesse em que um "muçulmano" a mais se arraste a cada dia até o trabalho; (Levi, 1988: 89)

Em nota de rodapé, o autor explica que o termo alemão muselmann, cujo significado é muçulmano, era usado pelos veteranos do campo de concentração para designar os prisioneiros mais fracos. A partir daí, muitas outras vezes, o narrador utiliza esse mesmo vocábulo para se referir aos presos destituídos de qualquer proteção e ineptos para a sobrevivência no 
Campo. É nesse contexto que percebemos a interseção mais óbvia entre a narrativa de Primo Levi e o romance de Mário de Carvalho. Se na obra de Levi, o termo "muçulmano", totalmente desvinculado de seu significado dicionarizado, referente aos seguidores de Maomé, funciona como designação pejorativa daqueles que ocupavam os lugares mais baixos na peculiar hierarquia de Auschwitz, em Um deus passeando pela brisa da tarde, como já foi comentado, parece decorrer de uma postura arbitrária a identificação dos mouros como bárbaros. Como dissemos, no período histórico aí retratado, não existia ainda a religião muçulmana, e o cristianismo era apenas incipiente, mas, mesmo assim, sem a usual justificativa religiosa, o elemento mouro é eleito representante da alteridade bárbara, que ameaça a estabilidade da Lusitânia romana.

É claro que, diferentemente do completo deslocamento significativo do termo "muçulmano", em É isto um homem?, no romance de Mário de Carvalho, a denominação de mouros, dada aos invasores, está atrelada, de fato, à origem étnica desses povos. O que tentamos ressaltar, no entanto, é que em ambos os casos a contemplaçáo do mouro e do muçulmano decorre de uma escolha deliberada desses elementos como representativos de uma alteridade impessoal, objetivada, reificada.

$\mathrm{Na}$ narrativa de Um deus passeando pela brisa da tarde, os invasores poderiam ser quaisquer outros estrangeiros, como os púnicos, também referenciados na obra, mas é apenas o elemento mouro, possivelmente devido ao seu papel significativo, no posterior desenrolar histórico da cultura portuguesa, que assume esse lugar. Já o texto de Levi reflete a realidade do campo de extermínio nazista, onde um linguajar próprio é constituído, juntamente com um conjunto de padróes sociais específicos desse microcosmo. E, embora a narrativa não apresente explicaçóes relativas a essa inusitada denominação, que identifica os judeus com terminologia designativa de seus inimigos históricos, essa atitude expressa, sem dúvida, uma preconceituosa ironia, pois são justamente os prisioneiros, em situação mais precária, que são designados, como "muçulmanos".

O seguinte excerto apresenta, de maneira impressionante, o esvaziamento de qualquer vestígio de humanidade nos chamados "muçulmanos":

A sua vida é curta, mas seu número é imenso; são eles, os "muçulmanos", os submersos, são eles a força do Campo: a multidão anônima, continuamente renovada e sempre igual, dos não-homens que marcham e se esforçam em silêncio; já se apagou neles a centelha divina, já estão tão vazios, que nem podem realmente sofrer. Hesita-se em 
chamá-los vivos; hesita-se em chamar "morte” à sua morte, que eles já nem temem, porque estão esgotados demais para poder compreendê-la. (Levi, 1988: 91)

Aqui, o narrador que vivencia e também observa atentamente a barbárie imposta no Campo de Concentração, elabora, entáo, o que nos parece ser a consequência mais brutal da situação: a formação de uma "multidão de náo-homens", que sequer pode sofrer, pois esse sentimento implica um traço da interioridade humana que eles já não possuem. Uma diversificada gama de violência, determinante da exaustão física, emocional e psicológica, justificaria, nesse relato, a alienação e desumanização de toda essa coletividade "muçulmana".

Prosseguindo, então, a analogia, anteriormente sugerida, entre os "muçulmanos" de Auschwitz e os mouros invasores da Lusitânia, estabeleceremos um paralelo, entre a citação acima, referente à multidão desumanizada descrita por Levi, e os seguintes trechos do romance de Mário de Carvalho:

Nada que se parecesse com uma ordem de batalha ou uma legiáo em marcha. Aparentavam antes uma revoada de insectos, amolecida pelo calor, perdidas as asas, dispersando-se cautelosamente na altura em que se lhes arrasa o ninho. Arrastavam-se indivíduos e grupos dispersos, uns carregando fardos, outros eriçados de armas rudimentares, outros trazendo o seu jumento, alguns a cavalo, a grande maioria a pé, pouquíssimos de carro. Não havia ali vanguarda nem retaguarda, nem vélites nem impedimenta. Era uma massa, dispersa, à toa, pela charneca fora. E mostravam-se tấo escuros e pobres os seus trajos que pareciam nascidos da terra e comungar da mesma constituição dos matos e tojos secos que pisavam. (Carvalho, 1997: 221)

Este excerto é parte do relato feito por Lúcio, quando vê, pela primeira vez, os mouros aproximando-se das muralhas da cidade. Nota-se que a pobreza e desorganizaçáo dos invasores, comparativamente às legiôes romanas, foi o que mais lhe chamou a atenção, comparando-os, por isso, a um agrupamento de insetos ou a uma massa disforme constituída por elementos telúricos. De forma análoga, o informante Airhan parece visualizar os mouros de um modo táo generalizante e superficial que, em sua descrição sobre esses povos, chega a compará-los às nuvens de gafanhotos: 
[...] Airhan comparava-os às nuvens de gafanhotos que em anos de praga fazem o mesmo percurso por sobre as ondas, revoada após revoada. E assim como esses animais depredam e deixam rasos de verdura os campos, assim estes invasores vinham para talar, por círculos mais e mais vastos, as fazendas e as vidas em redor. $\mathrm{E}$ as suas mandíbulas eram rudes armas de pedra e osso e o sinal da sua passagem a devastação dos fogos. (Carvalho, 1997: 55)

Nas duas citaçóes acima, a desumanização do mouro constitui-se através dos discursos de Lúcio e Airhan, ao valerem-se de analogias feitas aos insetos para descreverem esse povo. Já o seguinte fragmento, apresenta não mais o discurso, mas a própria ação de tratar o cadáver de um mouro como uma carcaça de animal, utilizada como objeto de exposição. Conforme descrito abaixo, os chamados rústicos, que seriam os cidadáos que habitavam os arredores de Tarcisis, mantinham o corpo do mouro coberto e só o mostravam àqueles que pagassem:

Os rústicos arrastavam os restos do mouro para que todos soubessem a notícia e os felicitassem e remunerassem condignamente pelo feito. Tencionavam continuar a exibi-lo, por todas as povoaçóes em redor, arrecadando como recompensa o dinheiro que a generosidade dos cidadãos quisesse despender. Como costumam fazer com as carcaças dos lobos ou dos ursos [...] (Carvalho, 1997: 143)

A animalização e coisificação dos mouros, presentes nas citaçóes acima, equiparam-se, de fato, à desumanização dos "muçulmanos" denunciada na obra de Primo Levi. Há, no entanto, um ponto fundamental que constitui uma inversão entre as duas constituiçóes narrativas. O relato memorial composto por Lúcio apresenta a visão de um cidadão romano, que tem como parâmetros apenas os referenciais desse Império, como as legióes romanas, por ele citadas. A desumanização dos mouros, nesse caso, é apresentada pelo discurso parcial do narrador que os percebe, principalmente, através da sua diferença em relação a um modelo muito específico de civilização. Já no caso da obra de Levi, o narrador é também um prisioneiro do Campo de Concentração e por isso a sua percepção desse outro, reificado, não se constitui por nenhum tipo de distanciamento cultural, mas justamente pela assustadora e terrível proximidade entre eles. E esse triz que separa o humano do que já não pode mais ser considerado um homem é que motiva grande parte das reflexóes apresentadas no texto. 
A possibilidade de se encontrar uma marca de humanidade, de dignidade ou de civilização é perseguida obsessivamente ao longo da narrativa. Mas, no contexto final da obra, apresenta-se a confissáo da experiência de completa animalização, vivenciada no Campo de Extermínio, desfazendo-se, assim, aquele tênue limite que separava a civilização da barbárie:

Jazíamos num mundo de mortos e de fantasmas. O último vestígio de civilização desaparecera ao redor e dentro de nós. A obra de embrutecimento empreendida pelos alemáes triunfantes tinha sido levada ao seu término pelos alemáes derrotados. É um homem quem mata, é um homem quem comete ou suporta injustiças; não é um homem que, perdida já toda reserva, compartilha a cama com um cadáver. Quem esperou que seu vizinho acabasse de morrer para tirar-lhe um pedaço de pão, está mais longe (embora sem culpa) do modelo do homem pensante do que o pigmeu mais primitivo ou o sádico mais atroz. Uma parte de nossa existência está na alma de quem se aproxima de nós; por isso, não é humana a experiência de quem viveu dias nos quais o homem foi apenas uma coisa ante os olhos de outro homem. (Levi, 1988: 173)

Nesta impressionante elaboraçáo, relativa ao reconhecimento da condição primitiva, bárbara e animalesca a que chegaram os prisioneiros, constitui-se uma conclusão ainda mais surpreendente, que pode ser melhor apreendida na junção dos seguintes fragmentos: "É um homem quem mata, é um homem quem comete ou suporta injustiças" e "[...] não é humana a experiência de quem viveu dias nos quais o homem foi apenas uma coisa ante os olhos de outro homem." (Levi, 1988: 173). Ou seja, a completa obra de barbarização humana, não se consuma nos atos de extrema violência sofridos ou praticados, mas na reificação do homem pelo homem. A incapacidade de reconhecimento da dimensão humana do outro é o que confere ao homem a verdadeira condição bárbara.

Esse pronunciamento assemelha-se com uma concepção de barbárie processada por Francis Wolff. Para superar a falaciosa definição maniqueísta de civilização e barbárie e a improdutiva relativização desses termos, Wolf elabora a seguinte proposição:

Chamaremos de bárbara toda cultura que náo disponha, em seu próprio cerne, de estruturas que lhe permitam admitir, assimilar ou 
reconhecer outra cultura - ou seja, a simples possibilidade de outra forma de humanidade. (Wolff, 2004: 41)

Assim, das elaboraçóes de Primo Levi e Wolf, aqui expostas, concluímos que a barbárie poderia se configurar pela incapacidade de reconhecimento e aceitação da alteridade. Mas, a apreciação de Lúcio e de seus concidadãos, concernente aos mouros, revela, exatamente, a impossibilidade de uma mínima compreensão de sua humanidade. E, se por um lado, a expectativa de uma elaboração, relativa à interação entre alteridades culturais, ou a própria terminologia aí empregada, parece totalmente anacrônica para o contexto histórico contemplado no romance de Mário de Carvalho, por outro, a forma como a narrativa de Levi é aludida parece provocar, de forma bem consciente, esse tipo de reflexão. E, realmente, os fatos referentes à presença dos mouros em Tarcisis são ínfimos, o que ganha destaque no texto é, justamente, a percepção dos cidadãos em relação aos invasores.

Ocorre que, embora a abordagem temporal de Um deus passeando pela brisa da tarde apresente uma rigorosa reconstituição histórica, fiel aos ideários da época, permite, entretanto, que uma precisa articulação dos fatos históricos resulte em estruturas, bastante originais, capazes de alcançar diretamente o período de enunciação do romance: final do século xx. Dessa forma, sem quebrar as expectativas internas de verossimilhança, o texto de Mário de Carvalho consegue comunicar-se com a nossa atualidade propondo, de forma sutil, reflexóes bastante perspicazes sobre assuntos complexos, como a questáo da alteridade.

É interessante pensar que o referido romance de Mário de Carvalho, publicado em 1994, e cujo tempo ficcional corresponde ao II século da Era Cristã, eleja, como parte de sua temática, a presença dos mouros na regiáo da Lusitânia. A peculiaridade da questão assenta-se sobre o fato de que nesse período, evidentemente, não existia, ainda, a religião muçulmana e, portanto, o conflito entre lusitanos e mouros não tinha o peso da motivação religiosa. E se, conforme apresentamos acima, há uma equalização desdenhosa dos estrangeiros, considerados como bárbaros, são apenas os mouros, aqueles que, de fato, são retratados na obra. Ou seja, se "o lado errado do Marenostro" é sempre o outro, o mouro poderia ser um representante dessa alteridade no imaginário português. Assim, poderíamos entrever, nessa obra de Mário de Carvalho, a sugestão de uma prevalência moura na cultura portuguesa que, para além dos fatos históricos e religiosos, alcançaria uma dimensão simbólica propícia para se designar o outro - bárbaro, invasor, exótico, diferente. 


\section{2 - A barbárie intrínseca à civilização romana}

Conforme colocado anteriormente, a presença do elemento mouro em Um deus passeando pela brisa da tarde possibilita outras reflexóes, também profícuas, sobre a questáo da barbárie. Nesse tópico, trataremos do assunto, partindo da seguinte situação: ao mesmo tempo em que a narrativa apresenta o cerco dos bárbaros mouros a uma província da Lusitânia sob o domínio romano, no ir século da Era Cristã, o narrador sugere a presença da barbárie no âmago, mesmo, desta sociedade. Decorre daí uma relativização do conceito de bárbaro como aquele que vem de fora: a barbárie, associada ao gosto pela violência, é reconhecida nas práticas cotidianas dos cidadáos romanos. Atentamos para a inusitada configuraçáo estabelecida na obra de Mário de Carvalho, que torna patente a disposição de representaçóes bárbaras no âmago de um Império que, ironicamente, se vangloriava por seu alto grau de civilidade.

Lúcio, ao insinuar, em sua narrativa, a presença da barbárie localizada no interior da civilização romana, não o faz seguindo o viés da alteridade, como foi discutido no tópico anterior, mas considerando, especificamente, as práticas violentas exibidas de forma espetacular para um público completamente embevecido. A seguir apresentamos um fragmento do texto memorial de Lúcio Quíncio, no qual se pode acompanhar a descrição das práticas selvagens ocorridas nas arenas de gladiadores:

O gladiador musculado que entrava de braços levantados, entre clamores, saía daí a minutos arrastado pelos pés, depois de o crânio lhe ter sido rebentado com um malho pelos oficiais da arena, travestidos de Caronte. Dentro em breve, nesta ou noutra hora, o mesmo aconteceria ao que o tinha derrubado. "Dá-lhe", "degola", berravam os lorários saltitando em volta dos combatentes de chicote em riste. Hiante, a populaça acompanhava em coro: “Derruba", "fere!". (Carvalho, 1997: 178-179)

O discurso de Lúcio, longe de reproduzir o tom de exortação manifestado pelos outros cidadáos romanos que assistiam ao evento, parece conter um vislumbre de assombro e indignação ante a violência dos acontecimentos por ele presenciados e narrados. De fato, se observarmos uma colocação anterior do protagonista, referente ao mesmo evento, percebemos uma atitude crítica bem sutil, revelada em uma interessante formulação, que sobrepóe o sentido de barbárie, simbolizado pelo sangue derramado nestes eventos violentos, à civilidade romana, presentificada pelos perfumes: 
Não sei se era impressão minha: parecia-me que, ao fim de algum tempo, o cheiro húmido, salgado, do sangue sobrelevava o odor dos perfumes preciosos que impregnavam a bancada em que nos sentávamos. (Carvalho, 1997: 177)

E, finalmente, no diálogo entre Lúcio e o imperador Marco Aurélio Antonino, o protagonista confessa a sua repugnância e incompreensão frente à carnificina praticada nas arenas. Mas, o imperador, admitindo que isso possa ser, de fato, considerado uma prática sacrificial humana, ressalta que, ainda assim, justifica-se como algo necessário para acalmar a ira do povo. O seguinte excerto apresenta o pronunciamento de Marco Aurélio dirigido a Lúcio, no qual fica evidente a defesa de uma "espetacularização da barbárie" para que se possa controlar a violência inerente à própria condição humana:

Olha que é falso que nós, Romanos, tenhamos acabado com os sacrifícios humanos. Apenas alteramos os procedimentos. O que proibimos aos povos submetidos são as suas formalidades peculiares de matar. E consideramo-los romanizados e felizes quando adotam os nossos ritos, que são estes. [...] Sabes? A sede de sangue é táo grande que, não podendo saciá-la nos anfiteatros, iriam saciá-la nas ruas. Se eu proibisse os espetáculos, voltaríamos talvez às guerras civis e às proscriçôes. Surgiriam outros césares. Devo correr esse risco? (Carvalho, 1997:186)

Assim, as camadas populares de Tarcisis ou de Roma, a quem Lúcio se refere, com desprezo, como turba ou populacha, são sustentadas pela prática do "panis et circenses", com ênfase à necessidade dos espetáculos violentos. Resulta, dessa conjuntura, uma forma de alienação popular astuciosamente aproveitada e promovida pelos governantes romanos. O tribuno Marco Agneio Scauro, representante do poder romano em Tarcisis, compartilha da visão da espetacularização da violência até mesmo nos procedimentos jurídicos, como o julgamento de Arsenna, um salteador capturado em Tarcisis, e dos seguidores fanáticos da nova religião, os cristãos. Em uma discussão com o duúnviro, na qual este recusa-se a aceitar a correspondência entre um julgamento e um espetáculo, Marco Scauro rebate:

Não achas? Não vai o povo assistir? Não se fazem apostas? Não há claques e entusiasmos? Não se comenta no fórum? Não é o assunto dominante de todas as especulaçóes? Não pode preceder um segundo 
acto, que é o dos suplícios e execuçóes? Náo exulta a plebe, de modo a ficar contente e grata? (Carvalho, 1997: 274)

A coerência dos argumentos de Scauro reflete, de fato, a estrutura alienante que predominava em todas as instâncias do Império. Verificamos, entáo, que as relaçóes entre barbárie e civilização, nesse contexto, alcançam uma configuração bastante complexa. A barbárie, associada ao sentido de violência, é compreendida como uma necessidade inerente à condição humana. Mas, para impedir que atos de selvageria comprometam as estruturas civilizacionais romanas, são promovidos espetáculos brutais, nos quais sacrifícios humanos são praticados, em um contexto esportivo de lutas e jogos. Dessa forma, a ferocidade dos cidadáos fica circunscrita aos circos e arenas de gladiadores.

Além do espaço específico, onde se promove uma barbárie controlada, várias manifestaçôes que pareçam comprometer os estatutos civilizacionais romanos - como o cristianismo, os mouros ou os bandidos - são juridicamente avaliadas, com todo o rigor das leis, para, então, serem eliminadas em sacrifícios festivos, também previstos nesses julgamentos. E, ordenando esse esquema de controle de criminalidade, através da prática circunscrita da violência, estão os governantes romanos, que, em posição bastante distanciada dos cidadãos comuns, não se comprazem desses espetáculos populares.

Assim, é o povo, de fato, que, alienado de sua capacidade de pensar, fazer escolhas, se revoltar, sendo, de certa forma, desumanizado, reproduz em sua relação com o outro, não-romano - o gladiador, o cristáo, o mouro - uma prática de reificação. É do interior dessa massa homogênea, cuja civilidade é extraída de práticas bárbaras, que se constitui a perspectiva desumanizada do outro e a incapacidade de reconhecimento e aceitação da alteridade.

E, nesse contexto, as tấo conhecidas palavras de Walter Benjamin tornam-se absolutamente precisas: "Nunca houve um monumento da cultura que não fosse também um monumento da barbárie." (Benjamin, 1985: 225). Nessa obra da literatura portuguesa contemporânea, pode-se confirmar a máxima elaborada pelo filósofo alemão, que destitui a convencional dicotomia "civilização e barbárie" e reconhece a presença da barbárie como estrutura intrínseca ao processo civilizatório. A aparente oposição entre a civilizaçáo romana e os invasores bárbaros é redimensionada, em Um deus passeando pela brisa da tarde, por uma estruturação narrativa, que evidencia, através da presença dos mouros, as práticas violentas e intolerantes necessárias para se obter o precário efeito de civilidade. 


\section{3 - Iunia Cantaber: a paixão traduzida como barbárie}

Já no início da narrativa, quando Lúcio encontra-se exilado e reflete sobre os problemas enfrentados, que teriam determinado sua condiçấo de desterrado, ele faz a seguinte colocação: "Ainda hoje olho com desconfiança quem venha do lado do Oceano. Mas será das praias que acorrem todos os perigos?" (Carvalho, 1997: 18). O perigo advindo do oceano são os mouros, mas uma condição fundamental para que Lúcio Valério perca sua posição de duúnviro e seja exilado de Tarcisis é o sentimento passional sentido por Iunia Cantaber, pois é isso o que compromete todas as decisóes públicas tomadas por ele. Assim, esse outro perigo insinuado na reflexão do protagonista-narrador seria, certamente, uma alusão à Iunia. Desde o princípio do romance define-se, dessa forma, um paralelismo entre a configuração ameaçadora dos mouros e aquela representada por Iunia Cantaber.

Tal perspectiva é reforçada também, em determinado ponto da narrativa, no qual a própria Iunia explicita sua identificação com os mouros. Isso ocorre no capítulo IX do romance, quando Lúcio surpreende Iunia Cantaber na intenção de enterrar um mouro, que seria apenas jogado em um lixo, e ela justifica sua atitude dizendo: "Este homem era meu irmão" (Carvalho, 1997: 147). A colocação de Iunia refere-se ao sentido cristão de irmandade entre os homens, mas funciona, ainda, como mais um indício da contiguidade entre o ataque dos mouros à Tarcisis e o sentimento avassalador que Iunia provoca em Lúcio Quíncio.

A angústia de Lúcio em relação à Iunia Cantaber é, de fato, bastante semelhante àquela experimentada quando ocorre a invasão dos mouros, e assenta-se, em ambos os casos, na incompreensão referente aos fatos inusitados e incontroláveis. Conforme apresentado no seguinte excerto, Lúcio Quíncio desenvolve um questionamento táo obsessivo quanto ineficaz acerca das motivaçóes dos mouros para agirem de forma, para ele, totalmente incoerente. Observa-se, ainda, em seu discurso, a crença um tanto pretensiosa de que o entendimento racional de tal situação poderia levá-lo ao seu controle e solução. Mas, utilizando os parâmetros civilizacionais romanos para refletir sobre a ação dos chamados bárbaros, Lúcio só pode perceber a desordem e incoerência da invasão moura:

Mas que deu àquela gente bisonha, mesquinha e bruta, para deixar, ululante, os seus desertos, [...] e vir desabar sobre a Lusitânia em correrias de sangue, talando fazendas, casas e gentes? Que ímpeto foi aquele que algum deus obscuro e ressaibado thes comunicou e que 
não perdoava madeira nem pedra, culpado nem inocente, livre nem escravo, e que trazia o único escopo de destruir e volver em deserto as cidades e os agros talentosamente erguidos por geraçóes que falam latim, cultuam os deuses e praticam o direito? Um exército conquistador pilha por turnos, poupa os vencidos, reconstrói as cidades, cobra o tributo, restabelece a ordem. [...] Mas, quando passa uma horda, deixa na terra a marca da pura irracionalidade, o restabelecimento do caos original [...] Por quê? Em nome de quê? Se tal eu soubesse, seria o mais sábio dos homens e poderia aconselhá-los com proveito. O por quê daquela ânsia dementada de destruir deve ser, de todos o mistério mais bem guardado. Não quis a divindade revelar-mo, apenas que lhe sofresse as conseqüências. (Carvalho, 1997: 16-17)

E, a persistente situaçáo de incômodo causada pelo sentimento inexplicável nutrido por Iunia causa, no protagonista, sensaçóes semelhantes a essas. A impossibilidade de comunicação com esse outro estranho, incompreensível, impenetrável, representado por Iunia Cantaber, revela-se, repetidamente, no discurso angustiado de Lúcio Quíncio, como se pode verificar nas seguintes colocaçôes: "Mas Iunia era um templo sem portas. Eu não conseguia descobrir nenhum acesso." (Carvalho, 1997: 163). Ou, um pouco adiante, em um trecho no qual se coloca o esvaziamento da própria humanidade de Iunia:

Impunha-se-me como que um obsidiante desafio de conseguir chegar a Iunia, à verdadeira Iunia, à humanidade de Iunia, por detrás daquele enleio espesso de frases e atitudes. [...] Ambos estávamos iludidos sobre a vulnerabilidade do outro. Ela, porque náo era pela sua piedade insólita que me tocava. Eu, porque sondava atrás das defesas de Iunia, onde, se calhar, não existia mais nada [...] (Carvalho, 1997: 166)

A incomunicabilidade entre Lúcio e Iunia parece mesmo estabelecer um distanciamento tão absoluto entre eles, quanto aquele apresentado pelo protagonista em relação aos mouros, como se pode depreender do seguinte fragmento:

E à alma de Iunia, seria possível aceder? Obter um sinal qualquer mesmo mínimo que significasse: olho-te, vejo-te, reconheço-te, compreendo-te? Eu não exigia mais que um momento em que as nossas palavras, em 
vez de se entrechocarem e enovelarem em linhas dispersas, eriçadas de asperezas, conseguissem convergir [...] (Carvalho, 1997: 170)

A aproximação entre o imperador-filósofo Marco Aurélio Antonino e Lúcio Quíncio, reveladora de uma perspectiva estóica, também presente no discurso do personagem-narrador, parece ser desconstituída à medida em que ele se deixa dominar pela intensa e inexplicável atração exercida por Iunia Cantaber. Os preceitos estoicistas ${ }^{1}$ de controle sobre as paixóes e de retidáo cívica e moral tornam-se incongruentes em relação às suas atitudes, pautadas, então, pelo desejo de se aproximar de Iunia e no intento de protegê-la da ira popular. O mundo civilizado, estóico e comedido de Lúcio é então invadido por um sentimento estranho, passional e excessivo.

Parece haver uma sobreposição de pontos de vista presentes ao texto de Lúcio, os quais refletem, às vezes de forma indissociável, o momento de rememoração dos fatos e o tempo pretérito em que eles foram vivenciados. Se algumas questôes relativas a sua atuação política e ao convívio com os outros magistrados puderam ser revistas de forma mais comedida e lógica, ao recordar os sentimentos experimentados por Iunia, entretanto, nota-se que a perspectiva do narrador permanece inalterada, imune a qualquer reflexão ordenadora. Além de não conseguir nomear, claramente, as sensaçóes arrebatadoras que lhe causara Iunia Cantaber, Lúcio apresenta, em sua elaboração memorial, uma atitude, ainda, perplexa e desconcertada.

Embora menos óbvio que os dois primeiros exemplos de barbárie, concernentes ao estrangeiro invasor e à violência romana, apontados anteriormente, a forma como Lúcio é afetado por Iunia e, ainda, a sua incompreensão frente a esse sentimento fazem com que o narrador a conceba como um elemento estranho, representativo de grande ameaça aos valores que lhe pareciam mais consistentes.

1 Lúcio, sendo contemporâneo de Marco Aurélio, pertenceria, cronologicamente, ao terceiro período do estoicismo romano, chamado estoicismo imperial ou novo estoicismo, representado, também, por Sêneca e Epicteto, entre outros. O item cinco, do livro V dos Pensamentos de Marco Aurélio, proporciona, de forma simplificada, uma noção geral dos aconselhamentos morais e regras de conduta representativos deste período da filosofia estóica: Faz-te a elas entáo, pois que dependem absolutamente de ti: sinceridade, gravidade, poder de agüentar, continência, aceitação do destino, moderação dos desejos, benevolência, liberdade, simplicidade, seriedade nos propósitos, grandeza de alma. (Marco Aurélio, 1971: 51) 
A contiguidade entre a maneira como o narrador autodiegético descreve sua interação com Iunia Cantaber e a barbárie em um contexto lato, advindo principalmente do sentido de alteridade estranha e ameaçadora, parece ter sido viabilizada, exatamente, pelas referências ao invasor mouro, contidas no discurso memorial de Lúcio. O modo como são pensados os mouros ou, mais precisamente, a dificuldade de apreensão desses povos, identificados como bárbaros, parece ter contaminado a estruturação narrativa e a percepção geral de Lúcio sobre toda a realidade a sua volta. Assim, de forma inconsciente, o narrador aparenta mimetizar, em suas preleçóes sobre Iunia Cantaber, as mesmas estruturas utilizadas para elaborar a relação de adversidade e alteridade referente aos mouros. 


\title{
Fabulário: (Re)Contando Mitos
}

\author{
Rosana Baptista dos Santos \\ Universidade Federal de Lavras
}


(Página deixada propositadamente em branco) 
Fabulário $^{1}$, de Mário de Carvalho, é uma coletânea de breves contos ${ }^{2}$ que, em oposição aos de A inaudita Guerra da Avenida Gago Coutinho, caracteriza-se mais amplamente pela forma dialogada. A estrutura e o conteúdo dos textos, relacionados ao próprio título da edição que encerra uma potencialidade ficcional, indicam uma composição literária fantástica $\mathrm{e}$, às vezes, non sense. Duas temáticas são recorrentes nos contos: a viagem a lugares diversos e exóticos e o encontro com civilizaçóes ou sujeitos 'diferentes' do que tradicionalmente se conhece, qualquer uma delas sugestivas de uma mesma necessidade de fuga do simples cotidiano. Além desses temas, outro procedimento de criação literária sistematicamente adotado pelo autor é o estabelecimento de um diálogo com a história e com textos clássicos greco-latinos. Em algumas obras, como Quatrocentos mil sestércios, por exemplo, Mário de Carvalho reproduz todo um contexto histórico, cultural e literário de uma Lusitânia romanizada. Entretanto, em outros textos, como Fabulário ou Fantasia para dois coronéis e uma piscina, os temas inspirados na tradição e literatura greco-latina aparecem 'aqui' e 'ali', de maneira fragmentária ou diluídas pela narrativa de uma forma indireta, ligados a assuntos ou questóes da sociedade e do homem moderno.

Agradeço à Capes (Coordenação de Aperfeiçoamento Pessoal de Nível Superior) pela concessão de uma bolsa de Doutorado Sanduíche para a realização da pesquisa sobre a obra de Mário de Carvalho, na Universidade de Coimbra, que resultou na publicação deste capítulo de livro.

1 A palavra 'fábula', do latim fabula (cf. gr. dóxa), acumulava já tradicionalmente os sentidos seguintes: a) no uso comum, "comentários, conversas"; estas são nuances abonadas, por exemplo, pela expressão conviviales fabulae - "conversas de mesa", ou pela interjeição fabulae!, "Tretas! Histórias! Disparates!; b) adquiriu então, numa adaptação específica à terminologia literária, o sentido de "narrativa sem base histórica, lenda, ficção" (cf. gr. mythos); c) "peça de teatro", dramatização de uma história; d) ou, por fim, "conto, fábula, apólogo", especificando um tipo de narrativa marcadamente moralista; Gaffiot, s.u. Etimologicamente liga-se a for, fari- "dizer", "narrar". Mais tarde suscita a formação do denominativo fabulor, fabulari, "narrar em forma dialogada". Com a mesma família semântica estáo relacionados, com sentido equivalente, os adjetivos fabulosus e fabularis. Cf. Ernout, A., Meillet, A. (1939), Dictionnaire Étymologique de la Langue Latine. Paris, Librairie C. Klincksieck, s.u. Vide ainda a definição de fábula em Reis, C. (1997), Fábula. In: Biblos- Enciclopédia Verbo das Literaturas de Lingua Portuguesa. Lisboa, São Paulo, Verbo: 462-463, 459: "Do ponto de vista formal, a fábula constitui normalmente um relato breve e concentrado numa acção simples, desembocando num desenlace de claro recorte moralizador (...) pode ser aproximada do conto, sobretudo daquele cuja inserção popular denota uma autoria indeterminada e uma transmissão oral". Todas estas especificidades de sentido estão, de fato, presentes na coletânea de Mário de Carvalho.

2 ( ${ }^{3}$ 1997), Lisboa, Caminho. 
Mas há, ao longo desses textos, referências a procedimentos, entes ou mitos que evidenciam, de modo concreto, o jogo intertextual com os modelos gregos e latinos. Assim, centraremos nossa análise na viagem (fantástica, simbólica) empreendida pelos personagens e na figura do 'outro', o interlocutor do viajante, retomados, muitas vezes, de forma irônica, ao apontar para a busca do indivíduo por um lugar ideal, por seu 'deus' ou sua identidade.

Proceder à análise da feição simbólica do tema 'viagem' em Mário de Carvalho conduz-nos a uma série de ponderaçóes sobre os componentes estéticos da narrativa fantástica, tanto a passada como a atual, sobretudo por estarmos diante de uma obra literária que estabelece um jogo intertextual com textos canônicos diversos, como veremos. O primeiro elemento que merece atenção é a figuração do protagonista, que propiciará pistas tanto sobre o aspecto simbólico da viagem, quanto de outros componentes do texto fantástico, como a composição do espaço, do tempo, do transporte e do objetivo que se espera alcançar.

De acordo com a perspectiva analítica que desenvolveremos sobre a viagem fantástica, iniciaremos pelas rubricas Exórdios, Países e Exemplos.

Como o próprio nome do capítulo indica, os temas tratados em Exórdios ${ }^{3}$ são o começo de uma urdidura narrativa que é ampliada nas rubricas seguintes. Sob a ótica dos gêneros, o exórdio possibilita uma projeção de informação, revelando "um determinado horizonte de expectativas pragmáticas que suportam a concretização de determinadas configuraçóes temáticas e semânticas ou ainda a sua derrogação total ou parcial". ${ }^{4}$ Dessa forma, os temas sobre o 'outro' como fuga de uma rotina, a busca de 'deus', a guerra e a configuração de terras diferentes, ou do impulso que mantém o homem vivo, aqui apenas sugeridos, são explorados de forma mais ampla nos textos seguintes.

Dos contos incluídos nos Exórdios, há dois que particularmente interessam ao tema que nos propomos desenvolver, a viagem extraordinária calcada nos modelos antigos $(13,19)$. Os personagens centrais não são nomeados, porque o que importa nessas narrativas é o caráter "moralizante"

3 Gaffiot, F., Dictionnarie Illustré Latin-Francais. Paris: Librairie Hachette, s.u. Exordium advém de exordiri "começar a tecer". Relacionado à língua significa "início de um discurso"; em sentido amplo - "começo, princípio, origem”. Na aplicação literária, aponta para a definição básica de uma trama, que depois se preenche, retoca e desenvolve.

4 Diogo, A. A. L. (1997), Exórdio. In: Biblos-Enciclopédia Verbo das Literaturas de Lingua Portuguesa. Lisboa, São Paulo, Verbo: 446-447, 446. 
da fábula associado à "busca" realizada pelo sujeito, anônimo e universal, e "o que" ele encontrará ao final da viagem. O primeiro texto, extremamente curto, funciona como uma espécie de preâmbulo a condensar, em traços abrangentes, o modelo em causa. Não há nele indicação do transporte utilizado, nem do tempo que se gastou na viagem; sabemos apenas que, movido pelo desejo, "um homem quis ir até ao fim do mundo e foi" (13). Primeiramente, há que se atentar para o personagem que se aventura numa busca do "fim do universo": identificado genericamente como "um homem", poderíamos afirmar que ele representa o Homem em sua busca incessante, quer seja através da literatura fantástica ou através da ciência, como da simples imaginaçáo, pelo conhecimento do que seria esse outro 'lugar', tão extremo e distante da realidade conhecida, e que seres possivelmente nele habitariam. Identificado, num anonimato global, esse sujeito, impóe-se de imediato outra questão: o que motiva a viagem. Nesse pequeno conto, o personagem "quer" ir ao fim do mundo, fator que o diferencia daqueles personagens dos primeiros contos que são lançados, sem consulta prévia, a uma aventura fantástica da qual náo querem participar. Acrescido à vontade, o simples registro de que ele 'foi', leva-nos a uma dúvida inevitável e para a qual não há uma resposta única: o protagonista foi realmente ou simplesmente viajou através da imaginação? Mas seja qual for o modo de concretização desse projeto humano, apesar de extremo, ele é mesmo assim acessível à determinação do Homem.

Executada a viagem, a paisagem do fim do mundo é revelada em termos vagos, mas expressivos daquilo que, sem se conhecer, se imagina grandioso, numa dimensão que se sente universal: "era uma grande falésia que dava para um abismo" (13). De novo a terminologia utilizada é extremamente ambígua, pois após as rochas altas (que em uma falésia comum dão para o mar) havia um abismo, palavra sinônima de voragem, precipício profundo ou em sentido figurado 'o que não é compreensível', 'o que é misterioso', ou ainda, simbolicamente, "aquilo que é sem fundo, o mundo das profundezas ou das alturas indefinidas". 5 Diante dessa visão de algo que o confunde e o desafia, uma dúvida assalta o homem: "Mas onde é que fica mesmo o fim do mundo? Aqui ou lá em baixo?" (13). De fato, o homem pergunta-se sobre o local em que ele mesmo está: início ou fim do mundo? $\mathrm{O}$ advérbio 'aqui' representa para o aventureiro o que é conhecido, o que é real, palpável, ao contrário de 'lá', que se afigura como incompreensível e que, por isso, pode gerar medo e desconfiança. Pensamos quase sempre

\footnotetext{
5 Chevalier, J., Gheerbrandt, A. (1982), Dicionário dos Simbolos. Paris, Teorema, s.u.
} 
que a posição de estar "aqui" ou de estar "lá" é uma disposição espacial antagônica simples, mas para o personagem essa relação produz mais dúvidas que certezas, porque ele encontra-se em um lugar fronteiriço. Esse entre-lugar produz no personagem a impressão de desorientação, ou distúrbio de direção, porque é, antes de tudo, um locus de deslocamento exploratório ininterrupto que oscila entre "o aqui e lá, de todos os lados, (...) para lá e para cá, para frente e para trás”. ${ }^{6}$

Também em busca de algo que lhe é caro, ou em fuga do que o martiriza, viaja o herói de um outro conto (19), por um meio que o narrador deixa oculto. Pela mão do acaso, ou de um impulso inconsciente, um velho mercenário chegou a uma cidade não nomeada, descrito como um homem "todo couraçado de armas". De início, o fato de o protagonista chegar coberto de armas provoca a impressão de que ele estaria em busca da guerra; mas o motivo da viagem torna-se claro: ao viajante agrada, pelo contrário, um sítio em que possa viver sem guerras, em paz; traduzindo em outras palavras, o mercenário procura despir uma identidade que o deprime tão somente pelo seu contrário. Assim, logo ao entrar, embora recebido de forma hospitaleira, foi detido pelos vereadores que o advertiram da proibição de andar armado na cidade. O homem pergunta o porquê dessa imposição para vir a saber que a cidade é da paz. Feliz, o mercenário afirma: "Enfim, tenho o que quero. Vou trabalhar de ferreiro" (19). O mesmo material, o ferro, passa a acumular duas conotaçóes: a guerra, simbolizada pelas armas, e a paz, expressa no exercício de uma profissão artesanal; ou seja, o homem quis mudar de vida sem perder a própria natureza. No entanto, quando tenta tirar as partes da armadura e deixar o escudo, "deu por que estavam embutidos na carne, como crostas, debaixo das quais havia um pulsar de carne viva" (19). Quando o viu, um vereador disse: "esse levou a guerra táo a sério que já nem sabe querer a paz" (19). Tema, de resto, sempre atual sobre que o narrador leva-nos a refletir: as guerras que perduram sem que se saiba realmente o porquê, ou melhor, que a história da Humanidade é a crônica de uma sucessão de guerras.

O personagem, ao aventurar-se em busca da paz, fez uma tentativa frustrada, porque a guerra havia tomado toda sua essência humana. A ima-

6 Cf. Bhabha, H. K. (1998), O local da cultura. Belo Horizonte, Editora UFMG: 19. Tomamos de empréstimo as reflexóes de Bhabha sobre os Locais da Cultura: a cultura se localiza no "entre-lugar'. A epígrafe de seu livro é elucidativa a este respeito. "Uma fronteira não é o ponto onde algo termina, mas, como os gregos reconheceram, a fronteira é o ponto a partir do qual algo começa a se fazer presente". 
gem do homem couraçado demonstra uma espécie de metamorfose pela qual passou o protagonista, pois havia se transformado, sem retorno, em uma 'máquina bélica'. Este é precisamente o mesmo rumo de pensamento da comédia Aves, de Aristófanes. Alguém parte à procura de um outro mundo, que não sabe qual é nem onde fica, porque o seu lhe desagrada (curiosamente, porque quer também trocar a guerra pela paz). Encontra-o no mundo ideal das aves onde não há dinheiro, nem tribunais, nem tudo aquilo de que fugia. Mas o herói ateniense também não é capaz de querer a paz e acaba contaminando 'a cidade das aves' com os males que não conseguia afastar, a tal ponto deles estava contaminado. Mário de Carvalho não vai tão longe, preserva a identidade pacífica dessa outra cidade, pela simples expulsão de quem nela não tem lugar.

Os dois personagens anônimos e solitários, destes contos de Exórdios, através de uma viagem, aproximam-se do que procuram, de forma que esse novo conhecimento ou lugar especial se constitui como um auto-aprendizado: no primeiro caso, o homem defronta-se com os limites da realidade que pretende ultrapassar, na busca de outra 'verdade' que tem a dimensão do universal; no segundo, o personagem inicia um processo que o leva ao conhecimento de si mesmo, e esse conhecimento pode pôr abaixo suas ilusōes de ultrapassar a sua própria condição. Aqui não há uma salvação do sujeito, e sim a constataçáo de que, respondidas as interrogaçóes ou buscas que o mantinham vivo, permaneceu como no estágio anterior. Falta realizar um movimento de 'ascensão' que de fato o liberte e o redima da mediocridade humana.

A rubrica Paises contém um grupo de seis textos, que, como o próprio nome indica, contam histórias de povos e países criados pela imaginação do autor e que, apesar de serem criaçôes ficcionais, relacionam-se a alguns aspectos históricos e a alguns temas literários específicos.

Em dois contos $(23,26)$, os povos são conduzidos pelo rei por uma longa viagem ou travessia. Assim o tema do escapismo parte do individual para o coletivo, numa flutuação a que a tradição grega tinha dado execução. O primeiro rei era movido simplesmente pelo tédio que o tomava; por isso ordenou uma mobilização geral para invadir a Índia, terra longínqua e desconhecida, mas promissora (23). À frente do exército, obteve muitas conquistas em longos anos de guerra, conseguindo inclusive tomar a Índia, uma espécie de nova Tróia. "Mas quando o rei quis regressar, com o seu exército, já ninguém se lembrava onde ficava o seu país. Tinham-no perdido" (23). Embora não possamos identificar integralmente as relaçóes intertextuais que o texto estabelece, parece haver "ecos" da Odisseia no 
conto: como na épica grega, o rei, após anos de ausência e guerra, apesar da glória alcançada através da empreitada, quer retornar ao seu país assim como Ulisses, mas isso é impossível, tornando o rei e seus companheiros solitários, ou melhor, estrangeiros e apátridas.

Invertendo os passos épicos, o conto não nomeia o povo ou o rei, não comenta as etapas da viagem, não insere deuses que agem a favor ou contra o herói, não comenta a recepção dos estrangeiros na Índia; enfatiza apenas o desejo do retorno, depois das glórias da conquista, a um lugar e a uma vida normal, mesmo se entediante ou rotineira. Além desse desejo de retorno, assemelham-se os textos pelo fato de o rei ter-se perdido como Ulisses esteve. Mas a Ítaca que se tornou, para o seu senhor, o desafio de uma nova aventura, a do reencontro consigo mesmo, parece vedada a um novo viajante, para quem a falta de regresso ecoa como uma condenação.

O conto pode ser entendido, ainda, como uma representaçáo da expansão marítima portuguesa, especialmente a empreendida por Vasco da Gama em direção à Índia e, assim, relaciona-se com Os Lusíadas, de Camóes, a voz de uma 'odisséia' lusitana. Embora o país invasor não seja identificado, sua ligação simbólica com Portugal parece evidente, na medida em que a narrativa demonstra passos parecidos com os da expedição portuguesa: enquanto a viagem avança e as terras são conquistadas, vão-se perdendo homens, ou porque morreram durante a viagem ou porque resolveram permanecer nos sítios em que aportaram. A expressão que fecha o texto "Tinham-no perdido" pode indicar também a perda do poderio português após as expansóes marítimas, ou que os esforços para gerir ou manter as colônias tivessem impedido os governantes de pensarem em seu próprio país, o que o fez, metaforicamente, cair no esquecimento. O que parece claro é a alusão a um Portugal que após a saga marítima não voltou, de fato, a ser o mesmo, tal como previra o Velho do Restelo, em $O s$ Lusiadas (cf. 4. 94-104).

O rei do conto seguinte tinha, para sua viagem, uma outra ambição: levava seu povo faminto e desesperado para "uma ilha fértil e verdejante que conhecia" (26). Não propriamente para escapar ao tédio, mas às dificuldades e à mediocridade, o soberano procurava soluçóes, sonhara com um troféu que esperava conquistar à distância. Tal como ocorre em algumas passagens da Odisseia, a imagem da ilha paradisíaca apresenta-se como um refúgio ideal e capaz de salvar um povo (ou um herói) da morte,

7 Camões, L. (1979), Os Lusiadas. Prefácio de Hernâni Cidade. São Paulo, Abril Cultural. 
oferecendo-lhe uma etapa de delícias e refrigério. De forma diversa dos outros contos que analisamos, o narrador informa o percurso que irá ser feito e 'como' iráo fazê-lo. Para alcançar o destino, "havia que atravessar a pé enxuto uma língua de areia de muitas milhas, aproveitando a maré baixa" (26) e o percurso devia ser feito em apenas uma hora, tempo que o refluxo da água permitia. Mesmo tendo que atravessar o mar para alcançar o destino, a escolha do meio de transporte é diferente das outras formas habituais que se utilizam, como um navio, uma jangada, a nado, levado pelas ondas: para atravessar o mar, teriam que caminhar. Há nesse desafio a sensação de um confronto, despojado de meios, em que o homem se depara, de mãos vazias, com a grandeza do seu sonho.

$\mathrm{O}$ conto possivelmente remete à passagem bíblica em que Moisés leva o povo do Egito para a terra prometida. Diante do mar Vermelho, o profeta toca com o cajado as ondas que se abrem para o povo passar, mas fecha a seguir, fazendo com que os perseguidores morram afogados. ${ }^{8}$ No conto de Países, o inimigo náo é um exército e sim a fome que fez com que o povo se demorasse recolhendo os mariscos. Assim como Ulisses e Moisés, o rei brigou e exortou o povo para que se mantivesse no caminho, mas de nada adiantou, porque os companheiros não largavam os mariscos, que comiam ali mesmo, crus. Logo veio a maré e "os quinhentos e setenta e sete membros daquela caravana, que formavam todo o povo, pereceram afogados" (26).

O rei age como um herói a quem foi confiada a salvaçáo de todo um povo, seus companheiros de viagem, e como ocorre com Ulisses, a responsabilidade pela morte dos companheiros não é sua, mas da imprudência dos outros. De resto, o tema da fome que levou os companheiros de Ulisses à desobediência ao seu comandante e à morte recorda o episódio da ilha de Hipérion (Od. 12. 340-425). O fato é que o rei conseguiu chegar "sozinho à ilha e aí ficou rei sem povo" (26). O isolamento para que caminha confirma a posição inicial dessa análise sobre a solidão do aventureiro. Solidão que exprime, antes de mais, a própria qualidade de ser herói, de possuir a grandeza para enfrentar dificuldades, de não se deixar vencer por carências e limitaçōes de natureza humana, em nome de um ideal superior. Esse é o segredo de glória que se consagra na solidão de um herói bem sucedido: a arte de conquistar a excelência e o preço a pagar.

Sugestivo é também, no seu simbolismo lacônico e baseado numa expressiva simetria de palavras, o conto (25) em que um homem veio do

8 Almeida, J. F. (1997), Bíblia Sagrada. Rio de Janeiro, Fecomex (Ed. Revisada e corrigida). Ex., 14.21-30. 
país hiperbóreo e disse: "Tivesse eu uma alavanca e levantava o mundo!" Veio outro e diz: "Tivesse eu um mundo e levantava alavancas." E "aqui começou a mais áspera desde sempre guerra religiosa”. Não se pode deixar de mencionar que a expressão utilizada pelo protagonista é uma repetição da famosa frase de Arquimedes dirigida ao rei Hierão: "Dê-me um ponto de apoio e moverei a Terra." (Dij87, p. 15). ${ }^{9}$ Tal frase foi proferida pelo matemático grego quando conseguiu desempenhar uma difícil empreitada solicitada pelo rei Hierão: jogar ao mar uma pesada embarcação deslocando-a só com uma combinação de polias e alavancas. ${ }^{10}$

Outra questão para a qual se deve atentar é que o país de onde vieram parece indicar um lugar isento de todo mal, arredado da civilizaçáo, 'branco' no seu desenho. O 'país dos hiperbóreos' contém, em Mário de Carvalho, o duplo sentido clássico, sacro e geográfico. $\mathrm{O}$ nome advém de uma possível localizaçấo, "para além dos lugares de onde procedia o vento Bóreas ou do Norte", ${ }^{11}$ ou seja, para além das fronteiras do mundo conhecido, 'branco' também em termos civilizacionais.

Heródoto referiu-se a esse povo, embora não admitisse sua existência. Sobre eles, afirma o autor de Halicarnasso que, “(...) nem os Citas nem nenhum dos outros povos que habitam na zona dão a mais pequena informação, a não ser os Issédones. Mas, julgo eu, nem mesmo estes têm nada a dizer, senáo também os Citas o diriam, do mesmo modo que falam de homens com um só olho" (4. 32) ${ }^{12}$. Se para o historiador a inexistência desse povo é evidente, na literatura grega são abundantes as referências a esse país como um lugar destinado aos bem aventurados. A propósito das referências aos Hiperbóreos na literatura, o próprio Heródoto dá-nos pistas dos autores em que ocorrem: "é Hesíodo quem fala dos Hiperbóreos, como também Homero nos Epígonos, se é realmente Homero autor dessa epopéia” (4. 32). $\mathrm{Na}$ concepçáo sacra veiculada pela literatura, o país dos Hiperbóreos é um

9 Dijksterhuis, E. J. (1987), Archimedes. Princeton University Press, Princeton. Translated by C. Dikshoorn. Apud Assis, A. K. T. (2008), Arquimedes, o centro de gravidade e a lei da alavanca. Montreal, Canadá: Apeiron Montral: 16.

10 Assis 2008: 16.

11 Errandonea, I. (1954), Diccionario del mundo clásico. Barcelona, Editorial Labor, s.u.

12 Segundo Heródoto (4. 33), o povo que mais se refere aos Hiperbóreos são os Délios, que afirmavam serem os Hiperbóreos quem enviava à Cítia ofertas sacras embrulhadas em palha de trigo. "A partir da Cítia, cada povo as recebia dos seus vizinhos e as fazia circular rumo a ocidente, tão longe quanto a costa adriática (...)". Tradução de Silva, M. F., Guerreiro, C. A. (2000), Heródoto, Histórias. IV. Lisboa, Ediçóes 70. 
local destinado aos eleitos, de onde o homem sai 'branco', como de uma espécie de ato criador. Píndaro (Pítica 10. 29-46) descreve-os como um país idealizado e maravilhoso relacionado a Apolo, para o qual não há caminho nem de barco nem a pé. Para os Gregos, os homens escolhidos pelos deuses iam para os Hiperbóreos gozar uma felicidade só possível no além, longe das doenças e livres da velhice. ${ }^{13}$

Prevalece, nesse conto, a idéia de que estes homens saíram desse (não) lugar "brancos", isentos de uma contaminação sociocultural (ou técnica). Uma leitura possível para o conto seria a de que com uma ferramenta mecânica, a alavanca, aqui emblema da técnica, o homem julga-se capaz de levantar o mundo, de dominá-lo até ao infinito. Mas se em vez da técnica, pensa o segundo personagem, possuísse o infinito (o espírito), teria o poder absoluto sobre todas as alavancas; ou seja, não é o homem que depende da técnica para atingir o infinito; é o próprio talento humano que deve conduzir e dominar a técnica. Sob esta ótica, há um detalhe importante além da pura simetria das palavras: ao cruzar o singular e o plural de alavanca, insinua-se a idéia de que o espírito é capaz de multiplicar a técnica e de fato dominar a descoberta e a capacidade mecânica. A guerra religiosa "mais áspera desde sempre" (25), iniciada após esse ambíguo diálogo, poderá estar relacionada com a maneira como cada um concebe a realidade que o cerca: as civilizações, ao longo da história da humanidade, distanciam-se exatamente porque algumas privilegiam a técnica e outras valorizam o espírito e, na maioria das vezes, são incapazes de aceitar as diferenças.

Do capítulo Exemplos, destaca-se ainda a viagem de "Luizardo, o auto-emparedador loucamente aventureiro" (57). A escolha vocabular para o nome do personagem, Luizardo (que sugere Felizardo, o que é feliz porque encontra a 'luz'), e para o nome da cidade em que mora, Sylampus, caracteriza o protagonista como alguém iluminado ou destinado à luz.

Cabe salientar a relevante oposição entre physis e nomos que aparentemente envolve o personagem. Segundo Kerferd, "o termo physis é traduzido por natureza", "natureza do homem" e nomos seria a 'lei', a 'convençáo'

13 Para uma discussão sobre concepçôes de felicidade após a morte, veja-se Rocha Pereira, M. H. (1955), Concep̧̧óes Helénicas de felicidade no além: de Homero a Platão. Coimbra, Marânus.

14 Vide Kerferd, G. B. (2003), O movimento sofista. Tradução de Margarida Oliva. São Paulo, Ediçóes Loyola: 189. Era também utilizado para designar "a totalidade da realidade", mas, em todos os casos, "o termo envolvia, pelo menos por implicação, um contraste entre as características apropriadas a uma coisa como tal, que ela possuía por direito, ou por sua própria vontade, por um lado, e características adquiridas ou impostas". 
ou o 'costume'. ${ }^{15}$ Como lei, nomos significa "norma legalmente prescrita, e (...) como convenção, é norma prescrita por convenção".

Já no início do conto percebe-se a contradição irônica com que o narrador define o personagem do dia-a-dia; ele é um auto-emparedador, ${ }^{16} \mathrm{o}$ que significa que "empareda", "confina" a si mesmo; e é loucamente aventureiro, algo paradoxal para quem quer apenas fazer paredes, sugestáo de alguém cuja physis (natureza) lhe aconselha ir além e procurar a luz, mas cujo nomos (norma) o prende entre paredes. ${ }^{17}$ Mas Luizardo não entendia que para exercer essa profissão tinha que ser um "homem sedentário ou bem medido nos passos a dar" (57), imposição de um nomos, uma regra social de vida, que difere da natureza. O problema é que nasceu em Sylampus, local em que não havia pedras, nem argila, nem cal, e todas as casas construídas eram de palha. E "um auto-emparedador, por mais imaginoso que seja não pode exercer-se numa terra de edifícios de palha" (57). Entáo, um dia, o rapaz pegou um mapa e de olhos fechados apontou para o acaso. Havia apontado para o país Hiperbóreo, para onde "se apressou a navegar na próxima carreira” (57). O fato de Luizardo navegar até lá teria um sentido figurado, já que como mostramos anteriormente, não há caminhos que levem a esse lugar. Novamente o país dos Hiperbóreos aparece em Fabulário, náo como ponto de partida, mas como destino do personagem, que apesar de ser descrito na literatura como um lugar especial, destinado a poucos, que podem usufruir de uma vida feliz e agradável, ${ }^{18}$ simboliza a morte (simbólica e real) para o personagem. Para decepção de Luizardo, nesse país não havia casas de tijolos ou pedras, e sim de blocos de gelo. Decidiu emparedar com gelo, cortando-o com uma faca. "Morreu congelado, já com dois palmos de parede prontos" (57). Ao que parece, o conto

15 Ibidem 2003: 191. De acordo com o autor, nomos e os termos "cognatos, em grego, são sempre prescritivos e normativos, nunca meramente descritivos - eles dão algum tipo de direção ou ordem que afeta o comportamento e as atividades de pessoas e coisas".

16 Cf. Arnaut, A. P. (2001), "Donas e donzelas n’a Demanda do Santo Graal", Santa Barbara Portuguese Studes. Califórnia, n. 5, 29-71. Na Demanda do Santo Graal, há personagens femininas chamadas emparedadas, que se recolhiam voluntariamente em uma estreita cela (para expiar culpas ou obter recompensas pela inocência castigada), cuja porta era fechada com cal. Esse caminho só era aberto para levar a mulher morta à sepultura. Eram as emparedadas confessoras ou conselheiras espirituais dos cavaleiros que buscavam o Santo Graal.

17 Para uma análise mais ampla dos termos, cf. Guthrie, W. K. C. (1976), Les Sophistes. Paris, Payot.

18 Rocha Pereira 1955: 38. 
valoriza a idéia de inadequação de sua physis às normas sociais, porque de fato sua natureza não mudou até a morte.

Em Fabulário, o retrato do protagonista e o objetivo da viagem, agora desenvolvido com o desenho do 'outro', não possuem uma feição única. Envolta pela fantasia, a função da aventura é a de propiciar ao personagem (e ao próprio Homem) uma reflexão sobre o papel que desempenha no universo que o circunda; o tema 'viagem' amplia-se, como potencialidade de encontro do sujeito consigo mesmo ou com o que lhe é estranho.

O herói pode partir sozinho em busca de suas aspiraçóes (14, 15, 16, 17); mas na maioria das vezes, sobretudo naqueles contos sob a rubrica Deambulaçóes de Cat' e Gat', é comum em cena um par viajante, o que possibilita a interlocução de idéias e as divagaçóes muito freqüentes sobre a nova ordem que encontram. Esta é uma técnica já presente em Aves, de Aristófanes, com Pistetero e Evélpides. Porém, ao contrário do que ocorre na comédia grega, ${ }^{19}$ em que um dos elementos do par contribui para a caracterização do outro ou tem um poder de comando superior, a função do companheiro em Fabulário é a de possibilitar uma discussão sobre uma ordem social diversa ou um evento ocorrido; esta reflexão encerra sempre uma "moralidade", ou teorizaçáo sobre as linhas de força de uma cultura. Os componentes do par viajante quase sempre têm, neste caso, uma posição de igualdade um em relação ao outro e nenhum possui uma autoridade ou uma "verdade" absoluta sobre determinado assunto.

As curtas narrativas sobre o motivo do 'outro' e da 'viagem' não se detêm em descriçóes pormenorizadas do trajeto percorrido ou dos traços psicológicos dos personagens, mas nem por isso prescindem da ponderação sobre a cultura, a sociedade e a vicissitude humana. Das variadas motivaçóes que levam os personagens a saírem de sua rotina, salientamos a busca voluntária de uma solução ou objetivo $(16,17)$, ou mesmo uma fuga desse sujeito (18), por um espaço ou nomos no qual sua alteridade seja aceita ou onde o encontro com seus semelhantes seja possível. Assim, essa viagem que o personagem realiza por vontade própria, às vezes é determinante para que escape da morte ou de um destino que lhe desagrada, pois ele sofre uma rejeição por parte da sociedade (18). Pode ser também objetivo da jornada a simples deambulaçáo sem destino, ao acaso, na qual os personagens não possuem um propósito previamente definido, pois o que lhes guia é a curiosidade de conhecer culturas e locais diferentes, como o fazem Cat' e Gat'; este é precisamente o mesmo motivo que conduz o

\footnotetext{
19 Cf. Aves 3 sqq.
} 
narrador de A História Verídica de Luciano de Samósata. Entretanto, esse passeio voluntário e sem destino, fadado sempre a um inevitável encontro com diferentes sociedades e culturas ímpares, em algumas ocasióes, conduz os aventureiros casualmente a destinos imprevistos, por uma ação da natureza, como um naufrágio (77), por exemplo, ou simplesmente porque se perderam no caminho (81).

Obviamente, que o acaso ou a vontade de ir além podem determinar os meios pelos quais se fará o percurso. Quase sempre precedidos de expressóes imprecisas de tempo como "Certa vez" (73) e "Era uma vez" (67), que introduzem igualmente as fábulas ou os contos de fadas, o itinerário e as distâncias percorridas manifestam uma constante indefiniçáo; assim as fórmulas estilísticas com que são expressos primam pela imprecisão e laconismo, na medida em que uma viagem fantástica ou simbólica não carece necessariamente de medidas concretas, como as estabelecidas por Luciano $^{20}$. Da mesma forma que ocorre em Aves, a distância é apenas sugerida nos contos como um "andar à deriva" (Aves 3-4), pois é natural que se (in)defina a extensão percorrida pelo herói com um simples "andou de terra em terra" (17), "fugiram (...) e instalaram-se" (18), "cortar caminho (...) num bote" (77), "calcorrearam montes e vales" (85) ou "iam andando, andando" (89), ${ }^{21}$ como uma forma de diluição de espaço e tempo, que permita uma identificação entre o mundo da fantasia e o mundo atual, sempre objeto de apreciação por parte do autor.

Percorrida a distância que separa o viajante de seu objetivo, avaliemos as primeiras impressóes sentidas e a paisagem (ou cultura) a que tem acesso no mundo diferente com que se depara. Nessas narrativas fantásticas, o personagem, às vezes, não se surpreende com o que encontra, porque é justamente o extraordinário que procura, como um país em que todos possuam quatro braços (17), por exemplo; o que não impede uma decepção ao se encontrar a terra para a qual quis viajar, porque apesar de realmente existir tal lugar, paradoxalmente, ele não atende as expectativas do personagem (17). Por outro lado, o efeito causado pela imagem da terra estranha e dos costumes que nela se praticam pode provocar uma surpresa aos visitantes que lá chegam por acaso, como ocorre com o encontro dos heróis com o excesso de estátuas que representavam gente humilde na ilha de Fezro (77); um simples enfado (e falta de compreensão) ante a monotonia e a pobreza deprimente de uma aldeia em que uma família constrói uma estrada sobre

\footnotetext{
20 Cf. História Verdadeira I.10.

21 Cf. a similaridade da situação em Aves 1-4.
} 
um pântano (85); ou, então, o receio e a inquietude sentidos frente a uma paisagem desconhecida e aparentemente ameaçadora (89).

Entretanto, a viagem não é o único meio pelo qual se pode ter acesso ao horizonte ou retrato do 'outro': em alguns contos (cf. 14, 15, 67), a alteridade é desenhada e acentuada através de uma aproximação paradoxal, no mesmo espaço, ou anacrônica, entre um ser aparentemente comum frente a outro diferente de seu interlocutor. A descoberta de um mundo antes inacessível e estranho por vezes é desencadeada após uma dissolução de fronteiras (real ou simbólica) que antes escondia ou impossibilitava-lhe o acesso. As fissuras, inesperadamente abertas na rotina do sujeito, ou em uma hermética muralha que o bloqueia, podem ser um canal que possibilita a uma sociedade um contato não com um mundo fantástico, mas sim com a physis a que de fato pertence e da qual havia se afastado em função de um "automatismo técnico" (27). Por outro lado, através da tradição antagônica entre luz e treva como emblema de conhecimento/falta de conhecimento, o encontro com a luz por parte de um sujeito pode ser a condiçáo essencial para que se tenha acesso a um mundo novo ou para que uma nova ordem social e cultural seja descoberta (28).

Através de uma posição diametralmente oposta do conflito existente entre Gregos e Bárbaros que ocorreu na tradição clássica, o tema geral desses contos é o encontro pacífico, ainda que não isento de incompreensão, de sujeitos que se interrogam em vários tons sobre um modelo mais satisfatório de sociedade, sobre o papel do coletivo, sobre o que é o conhecimento e a realidade, e, principalmente, sobre a identidade ou alteridade. Sem que Mário de Carvalho exclua os elementos com que a tradição desenhava essa hostilidade latente entre diferentes comunidades, como em obediência a um passado literário e cultural, o desfecho é, porém, o inverso da convencional tensão. Essa idéia de uma convivência pacífica entre aqueles que chegam e o 'outro' da fantasia exprime-se, primeiramente, pela forma como os viajantes são recebidos e ajudados quando estáo em perigo, obtendo uma boa acolhida $(77,81)$ na terra a que chegam, bem como pela alegria demonstrada pelos xenoi com a chegada dos visitantes (89). Assim, a caverna situada "a meio dum campo de pedras soltas, grandes, irregulares, rugosas, ameaçadoras" (89), por exemplo, de forma inversa de $O$ Ciclope e Ifigênia entre os Tauros, em que o cenário contribui para a caracterização de um ambiente hostil, não apresenta qualquer risco. A paisagem aparentemente perigosa do conto $A$ Luz é desmentida quando Cat' e Gat' entram na caverna e são bem recebidos pelos moradores (89), que respeitam a vida e a integridade física do hóspede. $\mathrm{O}$ fato de os visitados não possuírem um plano urbanístico 
e de morarem em uma caverna como Polifemo (Eurípides, Ciclope 115) indica uma espécie de primitivismo e isolamento, mas não um perigo aos visitantes. Estilisticamente, a manifestação de respeito pelo hóspede revela-se também pela liberdade e tranqüilidade com que o viajante percorre a regiáo desconhecida ou se dirige aos moradores do lugar com perguntas que visam a permuta de conhecimento e o cruzamento de informaçóes sobre os nomoi diferentes $(77,86,89-89,105)$. Logo, há uma aceitação da diferença que se demonstra através de expressóes repetidas como "ouviram polidamente" (78) ou "não ficaram surpreendidos" (90).

Embora os textos sejam marcados por reflexóes profundas, estas são feitas com um tom irônico (e às vezes cômico), diferentes do que ocorre na tragédia. Nem todos os elementos de que se servem os autores clássicos para definir o 'outro' estão presentes nos textos de Mário de Carvalho que analisamos, como a língua, por exemplo, um fator básico onde a idéia da diferença, traduzida na dicotomia Grego/Bárbaro, teve, como vimos, a sua origem.

Discorrer sobre o retrato físico do personagem em Fabulário implica relacionar o sujeito do mundo ficcional com o 'outro' grotesco e o insólito. Diferentemente do que ocorre nas narrativas de Heródoto ${ }^{22}$ e na tragédia esquiliana Persas ${ }^{23}$ - em que o retrato do 'outro' é mostrado não só através da descrição física, mas, sobretudo, pelo tipo de vestimenta ou adorno utilizado, ou por pormenores de etiqueta, como fatores que distinguem diferentes núcleos culturais, em si mesmos coesos -, em Mário de Carvalho esse sujeito pode não ser o 'outro' em relação a uma comunidade padrão harmônica, e sim um sujeito de exceçáo dentro da comunidade a que pertence. Nesse sentido, o 'outro' é visto de forma individualizada e, principalmente, simbólica de uma insatisfação ou de uma desadaptação do sujeito da diferença ao próprio nomos, expressa como uma reação profunda, natural e física. Dessa forma, o movimento de diferença, no plano coletivo, projeta-se de dentro para fora e não o contrário.

Entretanto, a construção ficcional desse ser diferente é estabelecida a partir de critérios do nosso próprio mundo, como o faz Luciano em História Verdadeira. Os seres monstruosos e estranhos que construiu deformam sempre um pormenor ou aspecto de seu ambiente ou cultura; as mulheres-videiras, por exemplo, embora fisionomicamente híbridas, são

22 Cf. Heródoto 1. 215 (sobre a descrição dos Masságetas) e 3.17 (sobre a descrição física dos Etíopes).

23 Cf. 81-182. 
compostas de elementos que Luciano conhecia, como uma parte do corpo feminino e a videira ( $H V$ I.8), apenas combinados de forma estranha. Também representativos desse tipo de construçáo fantasiosa, que tem como base um elemento tradicional deformado através de uma imitação cômica, são os componentes do fantástico exército lunar de Endímion, como as Hortaliças-Voadoras ou os Lançadores-de-Bagos-de-Milho (I. 13). Nessa mesma perspectiva de criação, Mário de Carvalho constrói a diferença de seus personagens acrescentando ou diminuindo membros ao modelo humano conhecido, simbolizando uma capacidade de fazer ou de agir mais poderosa do que a comum à espera de encontrar realizaçáo. Segundo Melero Bellido, nossa mente, diante de situaçóes novas, só se guia através da utilização da analogia com o que é previamente conhecido. A maneira de associar o ignorado e "o exótico mediante o mais conhecido ou cotidiano, segue alguns códigos que têm a ver com a tradução, com o que poderíamos chamar de uma gramática do fantástico, incluindo nessa categoria o exótico, o imaginário e o utópico". ${ }^{24}$

É este o teor do conto do homem que tinha duas pernas, mas que usava apenas uma para economizar energia (14); do cauteleiro que só tinha um braço e por isso se acautelava dos males sofridos pelos que tinham dois (15); do conto do menino que nasceu com quatro braços, em que todos reconheciam potenciais inauditos, ou que lhes permitiam, com exclusividade, obter tarefas particularmente exigentes (16-17); e do conto do gigante ${ }^{25}$ que imobiliza um braço, porque tinha demasiada força e fartura (67-69). Em todas as comunidades em que esses sujeitos vivem, reconhece-se seu potencial de energia superior; mas há uma incomunicabilidade e uma incompreensão perante a diferença, que se exprimem por perguntas surpreendidas, como a que faz o vizinho do homem que usava só uma perna: "assim não se cansa mais?" O homem responde: "Não posso" (14), porque seu objetivo é poupar e não gastar mais energia cansando-se, mas o diálogo traduz uma impossibilidade de compreensão da diferença. Essa é uma tensão também

24 Melero Bellido, A. (2004), "La lengua de la utopia”. In: López Eire, A., Guerrera, A. R. (Eds.). Registros Lingüisticos en las lenguas clásicas. Salamanca, Ediciones Universidad Salamanca: 150 .

25 O desenho do 'outro' como um monstro mítico ganha expressão nesse conto com um gigante "que vivia num altíssimo palácio, a meio da pradaria em que os ventos pararam" (67). Se na Odisseia e no drama satírico, o gigante Polifemo representa uma ameaça para quem aporta em sua ilha, em Mário de Carvalho, o gigante não representa um perigo para aqueles que o conheciam. Na verdade, o gigante é diferente de Polifemo (Cf. Eurípides, Ciclope 121, 123-124), pois, além de conhecer o vinho, cultivava hortas, vinhas e pomares. 
presente em relação ao cauteleiro que, diante de uma epidemia na cidade que provocava dor e inchaço nas "mãos dextras das pessoas" (15), ria muito, dizendo: "só eu não sinto nada" (15). Ironicamente sua mulher afirma que está isento da dor porque não possui "mão direita" (15), observação onde se patenteia a constante disparidade de leitura perante o estranho: "Sua parva... não entende nada" (15); de fato lhe faltava uma mão, mas a esposa não compreendia que ele tinha "potencialmente" as duas. Também surpresa, a mãe do garoto que nasceu com quatro braços, e que, por isso, se vê compelido a emigrar, pergunta-lhe para onde vai; quando o moço responde que vai para um país em que todos tenham quatro braços, a mãe contraria-lhe o projeto com a observaçáo de que "não há nenhum país desses" (16), o que demonstra uma incapacidade de imaginar a existência de algo tão diferente de seu próprio mundo.

Assim, as reaçóes das pessoas associadas a essas perguntas denunciam, no fundo, um tipo de riso trocista (ou de pura ignorância) e uma censura ao sujeito diferente, que expressam não uma aversão a esse 'outro', mas a incapacidade de lidar e compreender o que é diferente. A par do conhecido papel libertário, benéfico do riso, não se deve esquecer de seu papel coercivo, conservador e cruel sobre aquele que é seu objeto, ${ }^{26}$ pois, segundo Bergson, "o riso não pode ser absolutamente justo (...) Sua função é intimidar humilhando. Não conseguiria isso se para esse fim a natureza não tivesse deixado nos melhores homens um fundinho de maldade, ou pelo menos de malícia”. ${ }^{27}$ É com esse riso debochado, mas que expressa de fato uma falta de compreensão, que a prima do moço com quatro braços afirma que ele "na cama, hmmmmm, deve ser uma maravilha" (16). ${ }^{28} \mathrm{O}$ louvor da diferença de que é alvo o personagem por parte da família (16) assinala, através do elogio invejoso, o absurdo de sua diferença, que produz no 'ou-

26 Cf. Bergson, H. (2001), O riso: ensaio sobre a significação da comicidade. Tradução de Ivone C. Benedetti. São Paulo, Martins Fontes: 147.

27 Bergson 2001: 147.

28 Esse riso provocado pela ignorância teve expressão também na República, porque segundo Platão, no mito da caverna, aquele que havia visto o mundo exterior, em sua volta, para a caverna seria motivo de riso, porque estragara a visão com o sol, e que a tentativa de ascensão era inútil. Livro VII, 517 a e 518 a-b. Utilizamos a tradução de Rocha Pereira, M. H. $\left({ }^{10} 2007\right)$, Platão. República. Lisboa, Fundaçâo Calouste Gulbenkian. É importante ressaltar igualmente a idéia, comum em Heródoto, do significado do riso como exteriorização da ignorância; cf. 7. 103, 105. Xerxes ri quando Demarato afirma que somente mil homens lutariam contra o poderoso exército asiático. Tradução de Trejo, A. R. (1976), Heródoto. Histórias. Tomo III. México, Universidad Nacional Autónoma de México. 
tro' uma dificuldade extrema de lidar com sua alteridade frente à sociedade em que vive, o que o torna um ser solitário $(16,17,67)$.

Como os aventureiros de Aves, Pistetero e Evélpides, que partiram em busca de um mundo ideal, o moço e o homem que tinham quatro braços partiram em uma busca por seus iguais, à procura de um país em que todos tivessem também quatro braços $(16,17)$, ao encontro de um nomos compatível com sua natureza distinta, que os livrasse da solidão provocada pela diferença. É também por causa do isolamento que o gigante ensaia uma convivência com outros seres, mas a todos, numa manifestação de incapacidade visceral de convivência, perdeu por pura distração. Conclui, pois, que não serve para companhias (68), na medida em que sua tentativa de socialização (mesmo através da multiplicação de si mesmo em espelhos) fracassou (67); daí resulta uma espécie de incapacidade de viver em sociedade, que se exprime no ato de matar ou esmagar por instinto, involuntariamente, as companhias. Não podemos deixar de referir, que o exagero do tamanho do gigante é um elemento configurador do fantástico. Para Schwartz, a hipérbole (a do tipo que exagera por aumento) exprime na obra "como figura-chave que desvenda os mecanismos fantásticos da narrativa". ${ }^{29}$ De forma diversa dos outros que procuravam seus semelhantes, o gigante determinou que daí por diante viveria só. A busca pelo mundo ideal demonstra ao personagem de quatro braços (17) a exploração ou humilhação da diversidade; por onde passava, encontrou outras criaturas como ele diferentes que eram obrigadas a trabalhar em enormes torres, outras que eram mostradas em feiras e circos (17). Mas esse homem não quer se enquadrar ou submeter à norma comum, imposta por outro, e sim encontrar seu lugar no mundo, que na narrativa fantástica existe, mas não possibilita ao personagem viver sua diferença. A expressão que finaliza o pequeno texto do homem de quatro braços, "É expressamente proibido ter quatro braços" (17), encerra uma "moralidade", muito própria da fábula e que pode ser aplicada a todos os contos analisados acima: no mundo em que vivemos não há lugar para a diferença nem para se olhar para o 'outro'. Assim, o apelo dirigido ao gigante por um jovem é respondido involuntariamente com uma negativa, porque suas mãos estavam atadas para ajudar alguém (68), como uma espécie de metáfora para o sentido social e os valores da humanidade atual. Apesar de ter bons sentimentos e se preocupar com o jovem, o individualismo do gigante (e que cerca toda a sociedade atual como uma certa imposiçáo do

${ }^{29}$ Schwartz, J. (1981), Murilo Rubião: A poética do Uroboro. São Paulo, Editora Ática: 70-71. 
próprio sistema em que vivemos) impede que ele faça algo em função do próximo (69).

Logo, através do elemento fantástico, os contos retomam uma temática freqüente em Mário de Carvalho: a reflexão sobre a condição humana, sobre o sujeito "emparedado", completamente sem saída para seus conflitos com o nomos a que pertence, enfim sobre o absurdo de estar-no mundo. O homem que vive em sociedade está sempre usando "máscaras sociais" para ser aceito pelos pares, e, em função disso, o direito à alteridade vai desaparecendo. Pode-se dizer, então, que há uma crítica nesses contos à uniformização ou homogeneização humana, política, estética e cultural que ocorre nas sociedades modernas, que massificam, destroem ou rejeitam as idiossincrasias. A incomunicabilidade e a solidão dos personagens, "como conseqüências inevitáveis da existência humana, decorrentes de sua presença no mundo, são os elementos que acompanham, sem exceção, as personagens do universo" 30 ficcional de Mário de Carvalho.

Alia-se à temática da aparência do 'outro' e do conhecimento a importância da análise sobre a inversão da hierarquia social, dos valores e do sentido de areté, tema dos contos Outros tempos, outros ventos (77-79) e A tribo (81-83), de Fabulário. A imagem inicial do primeiro conto (77) é precisamente a mesma em que Ulisses, náufrago, é recebido cordialmente na corte dos Feaces (Od. 5. 450-494, 6 passim), numa retomada dos passos clássicos da narrativa de viagem. Entretanto, apesar de a hierarquia social se exprimir em Fezro por um meio convencional, que é a construção de estátuas e legendas, os valores para consegui-las são tradicionalmente contrários dos que conhecemos. Ali, as estátuas representavam somente gente humilde, cujas legendas eternizavam: "Fulano, varredor; Beltrano, coveiro; Cicrano, guarda-nocturno" (77), prática que surpreende a dupla hospedada na ilha. Os termos equivalentes aos que a épica homérica ${ }^{31}$ consagrou para a concretização dos valores elevados, como "ilustres", "os melhores", "imortalizados", "prestígio" e "fama" (77), constituem epítetos opostos à mediocridade, ${ }^{32}$ mas que aqui são dados aos anônimos. A areté para esse

30 Schwartz 1981: 82 refere-se à obra de Murilo Rubião, mas pensamos que a questão da incomunicabilidade e da solidão aplica-se, igualmente, à obra de Mário de Carvalho.

31 Alguns termos homéricos de valores guerreiros são: áristoi ("os melhores"), aristeía ("bravura"), timé ("honra"), areté ("excelência"), kléos ("glória, fama”). Veja-se Rocha Pereira, M. H. ( $\left.{ }^{10} 2006\right)$, História da Cultura Clássica, I, Lisboa, Fundação Calouste Gulbenkian: 122-143.

32 Essa espécie de endeusamento da mediocridade é representada também no romance Fantasia para dois coronéis e uma piscina, 106-108, no qual a divinização do futebol exprime a metamorfose de seus adeptos em bestas que destroem tudo que encontram pela frente. 
povo é entendida como o que é ordinário, insignificante, porque "as personagens ilustres não precisam de ser imortalizadas", afirma um vereador da ilha (77). O sistema de seleção de governadores da comunidade obedecia à mesma lógica: eram selecionados os cidadãos dispersos em meio da massa dos votados, o mais insignificante era o escolhido (78). Perguntado sobre o sistema pelos hóspedes, um homem explica que não é melhor nem pior que as outras cidades, mas ali se evitava o elitismo (78). Assim se relativizam os diferentes valores, que, mesmo se lidos inversamente, não são em si mais do que símbolo de estranheza, porque na realidade nada parecem mudar na vida concreta dos homens.

A tribo (81-83) aborda também a constituição da areté, da hierarquia social em tempo de guerra, vista como um terreno de aristeía ou de demarcação de valores. Em vez das profissóes em tempo de paz, do conto anterior, aqui é o comportamento em combate que define as hierarquias e os méritos. A tribo guerreira Bantshwanas, que deu abrigo a Cat' e Gat' quando estes estavam perdidos na savana, em conselho, discutia sobre um novo ataque de inimigos brancos; assim se estabelecem os termos com que a noção de areté da tribo se expressa pelo confronto dos valores desse povo com o dos brancos invasores. Enquanto os Bantshwanas, na guerra contra os inimigos, adquiriram fama pelos "feitos", "admiração" e "respeito" entre os povos do mundo (81), os brancos ganharam-na pela "perfídia", pela "traição", ${ }^{33}$ pela "superioridade das armas". Se no conto Outros tempos, outros ventos, as categorias sociais são estipuladas pela profissão medíocre, "o coveiro", "o varredor", "o barbeiro" (77), em $A$ tribo são dadas pelos clās, "da hiena", "do leopardo" e "do leão", que designam respectivamente esperteza, agilidade, coragem e força (82). De forma similar à tradição épica, segue-se uma descrição dos traços convencionais da areté de um guerreiro, em que os termos da aristeía são "o grito", "os pés velozes", a salvação do companheiro de armas ou o retirar do seu cadáver, e o saque das armas inimigas. O homem que detém todos esses traços de excelência, na épica homérica, é considerado o melhor por seus companheiros. Esses mesmos

33 O dolo e a perfídia como instrumentos para se ganhar uma guerra (ou uma batalha pessoal) é tema recorrente em Heródoto e na literatura grega em geral. O mais célebre exemplo é o estratagema do cavalo de madeira que fez ruir Tróia. De forma parecida, o reino da rainha masságeta Tómiris foi alvo de um expediente, primeiro quando Ciro pede-a em casamento com o intuito de tomar seu reino (Heródoto 1.205), depois quando usa o vinho e um banquete para neutralizar a força do inimigo (1.207). No plano pessoal, as tragédias Helena e Ifigênia entre os Tauros de Eurípides são um exemplo de como o ludíbrio pode vencer soberanos poderosos sem o uso de força. Vide supra 49-50. 
traços da aristeía sáo retomados no conto $A$ tribo (82): o grito guerreiro que amedronta o inimigo (Il. 5. 302, 591, 863); o retirar do guerreiro ferido ou morto do campo de batalha (Il. 5.296-301, 24. 469-691); a força e a coragem dos combatentes para obter fama gloriosa (Il. 5.01-03, 470); a ligeireza dos pés (82) (Il. 5.885, 16.5); o retirar as armas do oponente (Il. 5.435). Tais qualidades são recomendadas a Aquiles por seu pai: "que primasse pela valentia e fosse superior aos outros todos, para que não desonrasse a linhagem paterna" (Il. 6.208-209). O argumento de Aquiles, por seu lado, acrescenta-lhes a necessidade do herói épico de manter-se imortalizado através de seus feitos guerreiros. A interferência divina nos resultados da guerra entre os brancos e os negros, a "malquerença dos deuses" (82), da mesma forma é um motivo constante na Ilíada (15. 4 passim), agora retomado para a definição da aristeía de um povo.

Portanto, em ambos os contos, ressalta-se o valor da areté e da hierarquia social, mas em Ferzo temos um retrato do mundo ao avesso, em que contrapóe-se uma sociedade civilizada, urbanizada, paralela com a nossa, apenas com os valores ao contrário. Até mesmo as eleiçóes têm a estrutura do nosso mundo, porém com uma leitura inversa. Entretanto, a oposição extrema dos dois povos é uma falácia, porque há apenas uma relatividade de nomos, que, na concepçáo de seus habitantes, apresenta defeitos e vantagens. É o que Gat' pensa da organização daquela cidade (79): com a simbologia da troca dos remos de bordo para bordo, insinua que tudo é igual. Esse parece ser o retrato de nossa própria civilização, em que se imortalizam a banalidade e o ordinário. Porém, essa inversão de princípios (ou a vida em negativo) nada pode resolver, porque ela também tenderá para a mediocridade humana e civilizacional.

A mesma relatividade de nomos e de areté ocorre no conto $A$ tribo: ingenuamente decidem enviar um grande guerreiro para ter com os brancos, assim estes não iriam querer mais guerrear (83). Todavia, o chefe branco afirma que: "Temos de correr com aqueles ranhosos dos pretos para o deserto, que estão a ocupar muito espaço" (83). Na verdade, os Bantshwanas ignoravam que seus feitos ilustres, sua honra e seu nomos não tinham o menor valor para o arrogante exército dos brancos. Logo, o sentido de areté dessa tribo assenta na superioridade física, no respeito pelo adversário, na agilidade e na capacidade de mutaçáo e de resistência, e o do exército branco na quantidade de armas, de cavalos ou homens de um exército, em uma total falta de simetria em relação ao nomos e ao modo de guerrear dos Bantshwanas. Heródoto usa exatamente os mesmos critérios para distinguir os povos civilizados dos selvagens: os Persas impóem-se pelo número, 
pela variedade de batalhóes (1. 103, 3.25, 4.83), enquanto os "bons selvagens" (Masságetas, Etíopes e Citas) pela superioridade física (3.17-18, 21), resistência $(4.126,131)$, finura (1. 206). Os contos traduzem duas leituras contraditórias, que servem à verdade que cada um queira ver: essa é a "moralidade" que se quer transmitir, a noção de que a verdade é relativa.

Em conclusão, entendemos que esses textos discutem, de forma simbólica, o "estar no mundo" de personagens que representam o Homem "cercado" por um universo opressivamente restrito, que por isso mesmo são guiados a uma "re-velaçáo" ou a um "des-velamento" 34 de sua própria condição. Assim, o jogo entre luz/trevas, conhecimento/ignorância, riqueza/ pobreza, homem comum/poeta-profeta, mundo interior/ mundo exterior são constantes na narrativa, que se orienta sempre para a demonstração de que não há uma verdade ou um conhecimento único, além de exprimir uma clara insatisfação com a moderna civilização ocidental dentro de cuja cultura são pensados. A análise geral da temática da viagem e do 'outro' em Fabulário demonstrou, através da fantasia (e do fantástico), ${ }^{35}$ da relativização e da "moralidade" própria da fábula, um panorama da própria crise civilizacional a que estamos submetidos, porque "a ficção, entendida como um discurso de alteridade, justamente por isso se presta à crítica aos mais diversos aspectos da cultura e da sociedade; portanto, falar de ficção supóe sempre falar de sociedade e cultura (...)"36.

34 Empregamos os termos usados por Fialho, M. C. (1992), Luz e trevas no teatro de Sófocles. Coimbra, Instituto Nacional de Investigação Científica: 72.

35 Cf. a definição dos termos que adotamos na Introdução.

36 Brandão, J. L. (2001), A poética do Hipocentauro. Belo Horizonte, Ed. UFMG: 27. 
(Página deixada propositadamente em branco) 


\title{
Neoars Moriendi: Mário de Carvalho e a nova arte de morrer
}

\author{
Tereza Virgínia Ribeiro
}

Universidade Federal de Minas Gerais 


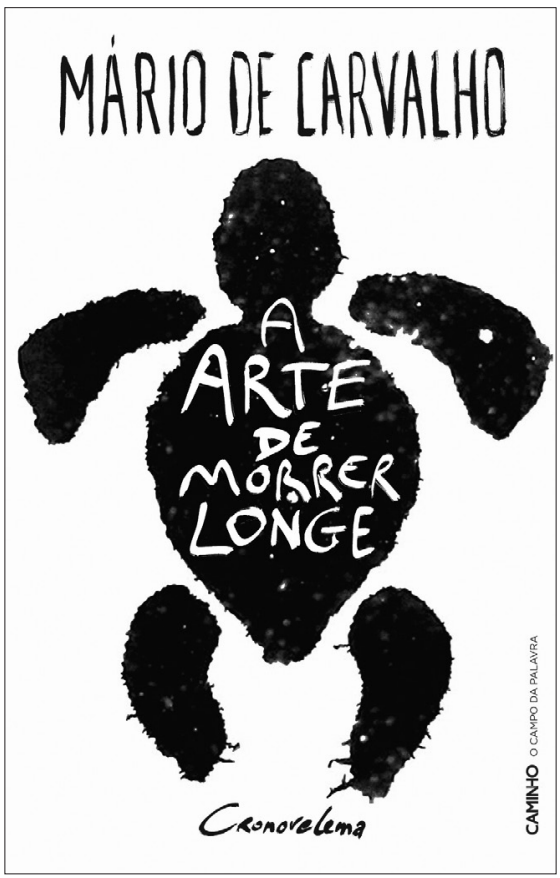


$A$ arte de morrer longe (2010), de Mário de Carvalho, é mote para começar o nosso assunto. Começar, está dito, porque será difícil esgotar as possibilidades e, prometendo tal coisa, corremos o risco de morrer na praia, como se diz no Brasil. Usaremos, como estratégia de abordagem, a manipulação da obra pelo seu veículo físico, o livro materialmente falando. Trata-se de um volume de corpo pequeno, despretensioso, mas já na $2^{\mathrm{a}}$ edição (reimpressão) e com a tiragem de 3 mil exemplares. São 128 páginas, capa branco envelhecido. A ilustração da silhueta de uma tartaruga, em negro e com manchas verde-escuras, ocupa toda a capa; o nome do autor, em caixa alta, tem destaque; o título, na posição central, que, com alguma liberdade na analogia, poderíamos considerar a carapaça do réptil, está grafado também em letras maíusculas, porém, diferentemente do nome do autor, a fonte tipográfica escolhida simula uma escrita em manuscrito (o que, para o leitor, sugere, de alguma forma, o pessoal, o particular, o quase intransferível, o segredado, como que a dizer: "Da arte de morrer longe cada um terá a sua...”). Na lateral consta o nome da editora em fonte comercial.

Abaixo, novamente em imitação de manuscrito, contudo agora mais pessoal ainda, porque em cursivo minúsculo, lemos o termo indicador de um gênero literário heteróclito e inaudito, o "cronovelema", composto que nos parece mostrar a intençáo de gerar e marcar uma narrativa que foge a quaisquer tentativas de enquadramento e que se recusa a encaixar em posiçóes canônicas quer seja a do romance, da crônica, da novela, do conto ou, quiçá, do poema. ${ }^{1}$ Em entrevista a Luísa Costa Gomes, ${ }^{2}$

1 Respondendo a Rui Lagartinho, o escritor será breve, limitando-se a dizer que o cronovelema "é uma súmula onde se misturam a ideia de crónica jornalística actual mas também a velha crónica do género 'Os feitos que neste reino foram...' de Fernão Lopes, o cronista de Lisboa. Mas também a novela, o conto, o poema, o cinema." (http://timeout. sapo.pt/news.asp?id_news=5371, em 27 de abril de 2010). No entanto, a objetividade não nos deve enganar. Há muito na elaboração dessa categoria, que por enquanto é de inteira responsabilidade de um só autor, Mário de Carvalho. Digamos que o poema não se vislumbra só nos momentos líricos dedicados à cidade, mas na forma de expressão. Cf. 105 (grifo nosso): Eis a bela Avenida de Roma, nem grande nem pequena, nem larga nem estreita, epítome da mesura e da moderação, nos volumes, nas linhas, na dimensão, na cor. Eis os vastos passeios reticulados de pedrinhas de lioz, a dar brilho às fachadas, com os golpes de sol, ou a reflecti-las, em fluorescências multicores, quando escorridas de chuva. Eis a elegância das cores esbatidas, sossegados verdes e rosas-pastel, os prédios discretamente comedidos, num alinhamento de harmonias burguesas, distintas, reservadas, boas marcas, bons colégios, talvez mais reputados que bons, negócios turvos, recato de vida, golas altas, casacos de tweed, bombazinas caras, livros em francês.

2 In http://www.homemmag.pt/pt/index.php/arte-e-literatura/arquivo-arte-literatura/87-luisa-costa-gomes-entrevista-mario-de-carvalho Criado em 25 julho 2012 19:16. 
Mário de Carvalho, esclarece sobre a ligação deste novo conceito com a velha e conhecida "crônica" e sustenta que, tal qual Gomes sugere, a categoria recém-fundada parece visar à "recuperação de géneros e subgéneros que não foram dominantes na literatura naturalista.", Mário de Carvalho afirma que

[o] cronovelema tem que ver com esse espírito de apreciação daquilo que está à volta, de captaçáo do nosso tempo e gente; mas tem que ver com outra coisa, do ponto de vista técnico, tem a ver com a libertação de uma série de proibiçóes. Lembro-me ainda do tempo do neo-realismo em que havia imposiçóes sobre o escritor, os próprios meios onde ia buscar a matéria-prima, as situaçóes, as personagens... (...) se apontava sempre um futuro de transformação social. Mais tarde veio uma nova malha de imposiçôes - e de proibiçôes, também. Foi a altura do nouveau roman. (...) Eram proibidas categorias da narrativa como as personagens, a acção, os conflitos, alterou-se completamente a noçáo do espaço e do tempo narrativos e as categorias que o romance tinha construído até aí desapareceram.

(...) É sempre importante que haja alguém que alarga os limites deste continente.

(...) a aceitação do desaparecimento da história, a dissolução da personagem, a multiplicaçáo sinfónica das vozes, e mais tarde com o estruturalismo, a da existência autónoma da escrita - a tal aventura da escrita em vez da escrita da aventura, como dizia alguém, náo me recordo quem - foram marcantes nos anos sessenta do século passado. E essa "arte poética" ia-se-nos inculcando.

(...) Mas Os Contos da Sétima Esfera, tal como os seus Contos de Sobressalto, como outras coisas que apareceram por essa altura, representaram um respirar fundo, uma forma de libertação destas superstiçôes, dessa normatividade, dessa espécie de deontologia do que se pode e não se pode fazer. Voltou-se às personagens, voltou-se a contar as histórias, e reintroduziu-se uma temática abandonada e rejeitada anos antes, que era precisamente a temática do insólito, do mágico, do maravilhoso...

(...) $\mathrm{O}$ cronovelema não rejeita nada e não se sujeita a imposições. $\mathrm{Ou}$ seja...

(...) Faz exactamente o que lhe apetece.

(...) E não tem de se submeter a carimbos nem a rótulos. E decide convocar a crónica - pode ser a velha tradição da crónica, como as do 
Fernão Lopes - mas pode também ser esta magnífica crónica do Eça de Queirós e pode ainda ser a crónica jornalística

(...) Tenho três cronovelemas, o primeiro é o Era Bom que Trocássemos umas Ideias sobre o Assunto, o segundo é a Fantasia para Dois Coronéis e uma Piscina e o terceiro é este e todos eles têm este viso irónico e zombeteiro. Vem da sua componente de crónica.

Ser um gênero tão indeciso - ou aberto - seria o bastante para nos convencer a lê-lo, pois que nos instiga e provoca o despertar de um antigo e pueril interesse pela novidade que se propóe ao pé da capa. Esta moção impulsionada comprova-se do mesmo modo na segunda epígrafe, colocada na folha de rosto da obra, retirada do romance cômico Three Men on the Brummel do quadrinista Jerome K., a saber, " 'What we want', said Harris, 'is a change"." Se queremos uma mudança, o cronovelema parece vir para responder a este anseio.

Todavia, em si, o termo "cronovelema" se liga igualmente, ou pelo menos por analogia sonora, com a palavra "problema", além de estruturar todo o conteúdo da narrativa em torno da tribulação de possuir uma tartaruga indesejada. Problema é também a questão de sua categoria literária, que se deixa atrair pela ruptura com o cânone para adentrar caminhos indisciplinados. Vejamos em que ponto podemos classificá-lo como um cronoproblema. O composto sugere, pelo antepositivo "crono", uma associação (por afinidade etimológica de origem clássica) imediata com a crônica, narrativa curta que relata uma história de nossos dias. No caso, acompanhamos o acontecimento nada épico da separação de um casal, que de resto não é exclusivo de nossos dias. Se privilegiarmos o radical crono-, expressão de tempo presente no lexema crônica, parece-nos que haveríamos de cortar - tal qual um Procusto - boa parte da história. Indecisos e constrangidos pelo enredo, estaríamos propensos a classificar a obra como um romance, mesmo que aparentemente não haja, no referido neologismo, a presença morfológica do gênero romance. Aqui cumpre recorrer à cautela: pois não poderia, acaso, essa presença ser marcada pelo vocábulo inglês "novel”? Ou devemos entender a referência direta ao significado em português da palavra "novela"? Especulações à parte, porém, como em um romance, a narrativa de $A$ arte de morrer longe se compóe de elementos heterogêneos e descontínuos em organicidade, com princípio, meio e fim que nos levam a um todo homogêneo (Lukács, 2000: 85-96).

O problema da classificação parece ridículo quando observamos que, se a obra for encaixada no que chamamos "romance", se-lo-á pelo avesso 
- um romance que se nega como romance - um "pós-alguma-coisa", "pós-crescimento", "pós-casamento", "pós-agregamento", "pós-euforia”. Não se nega que o autor reserva para a voz do narrador procedimentos romanescos (ele abre sua obra; constrói seu discurso de modo assumidamente intertextual; convoca e aproxima leitores e autores, referências e saberes; assume o metadiscurso em crescente autorreflexividade), mas não se nega também que a extensão de mundo das personagens recaiu sobre o curto espaço de tempo da vida de um casal suburbano em rixa e tédio amoroso no ápice do rompimento travado pelo desvencilhamento de uma tartaruga. Em contraponto, há uma breve incursão - breve como a das novelas televisivas - a episódios curtíssimos da vida da mãe (sem nome) de Arnaldo, de Gervásio Neves Escarrapacha ${ }^{3}$, de Carlinda, Coriolano etc. e acrescente-se aos microepisódios as chamadas típicas de radionovelas:

Iria a máe de Arnaldo sair vencida deste transe? Como encontrar o agente da polícia tão severa e competentemente justiçado? Como dizer ao homem que ela não pretendia tanta justiça? Como descarregar o sentimento de culpa que lhe esmagava o coração e toldava o entendimento? Eis as dúvidas cruéis e lacerantes que então a atormentavam.

Ironicamente até poderíamos alocar a narrativa composta num lugar de "vizinhança", em compartimentos contíguos, "parede-meia", como se diz no Brasil, que dividiriam a "novel" e a novela. Como crônica, a narrativa desdenha dos fatos pontuais da história contemporânea da cidade de Lisboa, a antiga Olissipo que é descrita com uma aura de especificidade ilusória quase beirando a um poema. A novela que se apresenta em $A$ arte de morrer longe inclui a influência de várias outras, inclusive das telenovelas (Carvalho, 2010: 47, 70, 98, 99...) que deveriam, pelo menos na opiniáo do autor, flertar, propositalmente, com esse novo gênero por ele estabelecido.

Assistiam a uma daquelas intermináveis peças narrativas que as televisões exibem por volta da hora do jantar e que dão o nome de telenovelas, folhetins televisivos que parecem destinados de propósito e muito sabiamente às pessoas que deixam divagar o espírito para

3 Dada a erudição do escritor lisboeta, não podemos deixar de aludir à utilidade de considerar com atenção a onomástica cuidadosa. Apesar de este não ser o foco deste trabalho, salientamos o significado do nome "Escarrapacha", derivado do verbo homônimo o qual designa uma postura corporal humana que reproduz a forma de uma tartaruga. 
longe do clarão em que os olhos estáo postos, como acontece aos casais desavindos. As situações e as próprias falas são habilidosamente repetidas, de maneira que, por mais distraído que se esteja, há grande improbabilidade de se perder o fio da história. Diferentemente seria se as televisōes, num rasgo inovador, se dedicassem aos cronovelemas, invenção de certo escritor que amanhã nomearei. (Carvalho, 2010: 99)

Três elementos no trecho nos atraem: a possibilidade aventada de mudança de telenovela e crononovelema, a leve e tênue associaçáo com a Alegoria da Caverna que o filósofo antigo propóe na República (o tema permeia, verdadeiramente, toda a obra de Mário de Carvalho. Nas páginas seguintes faremos alusão a algumas passagens. Contudo, não nos debruçaremos sobre o tópico que, a nosso ver, é matéria para tese) e, finalmente, o uso fluido e nunca controlável do advérbio de tempo de maneira que ele possa permanecer sempre, eternamente, como um imutável "amanhã”. Mas o problema de classificação que realça o neologismo continua. Ao radical novel-vem atrelado o sufixo -ema que nos conduz - incertamente - a uma outra forma literária, o poema. O sufixo -ema, artifício para criar um pseudocientificismo literário, segundo Houaiss, é

"um dos sufixos mais privilegiados na terminologia científica contemporânea" (...) "ocorre, predominantemente, em grecismos, como diádéma, atos 'diadema', kinéma, atos 'movimento', phônéma, atos 'som da voz, palavra, discurso', poiéma, atos 'obra, invenção, poema', theôréma, atos 'espetáculo, objeto de estudo, teorema'. (...); com relação a este sufixo importa notar que tem aparecido em neologias científicas com o sentido de 'unidade mínima estrutural'."

De fato, temos na prosa que se apresenta uma unidade mínima estrutural que começa e termina pelo paradoxo da brandura que traz no âmago a violência. E assim se consolida "literária e cientificamente" o cronovelema, se é que o sufixo se presta a cientifizar o termo. Este novo gênero (ensaiado já por duas vezes) nasceu e permaneceu como categoria aberta, fabricada em amálgama, liga de muitos "radicais", vislumbrada no compósito e enigmático que o define. Encerrando este "bate-bola inicial" anuimos à opinião de José Cândido de Oliveira Martins (2011: 42) em relação ao vocábulo:

(...) presenciamos a configuração gradativa e metaficcional de um novo género ou conceçáo libertária e atualizada de narrativa, na pena 
de Mário de Carvalho. Por um lado, a escrita do autor recupera e celebra uma certa tradição ficcional (de Cervantes aos clássicos anglo-americanos como Lawrence Sterne ou Charles Dickens), apostada ela própria em reinventar, metanarrativamente, a arte da ficção, através de um novo realismo e até do grotesco quotidiano, mas também através de uma cultura do humor e da paródia, concebidos na sua função eminentemente crítica.

Admitamos, pois, novo estado poético para abrigar uma narrativa sobre a arte de morrer longe. Não cabe avançar muito, mas vale lembrar que se estabelece uma relação - provavelmente irônica, mas não necessariamente - com uma série de produçóes recorrentes na Idade Média e Renascimento: as ars moriendi, artes do bem morrer (e, quiçá, as de escrever, de amar e outras "malas artes"). Porém, não podendo nos aprofundar no aspecto acima, que se constitui mais um outro tema de teses que nos proporcioa este autor português, neste lugar de nossa análise, nos perguntamos apenas: onde fica "o longe"? A resposta nos faz cair na mesma armadilha do advérbio "amanhâ", referido linhas atrás. "Longe", no título, assim como está, é um nunca controlável, um sempre imutável "longe". Mas "[a]qui" (e observem bem a utilização do advérbio "aqui"), "aqui há que condescender com as convicçôes entranhadas, tolerar as daltonias íntimas, garantir a liberdade poética, libertas vatum." (Carvalho, 2003: 17). E, pensando em tópos, em lugares de enunciação, tomemos as palavras de abertura da narrativa. Elas são emblemáticas da escrita de Carvalho, que invariavelmente declara seu grande amor pela cidade de Lisboa e acaba por cair da paixão lírica ao tédio e ao cansaço contemporâneo. O lírico: "Na bela e nunca por demais celebrada cidade de Lisboa, urbe das urbes, afamado remanso de brandura, nimbado de zimbórios e palmeiras...”; observem, Lisboa é descrita bucólica e placidamente e, en passant, qual um nada a dizer é nomeada imperialmente "urbe das urbes". A estratégia nos leva a ver uma cidade antiga, latina e majestosa, com as altas cúpulas das igrejas, em seus picos, cercadas de luz celeste; a abóbada da romana Basílica da Estrela, de Santa Engrácia, sinais inequívocos do poder de um outrora, tudo definido como um "afamado remanso de brandura”. Há uma coincidência excludente neste quadro: poder e brandura que desaba no tédio nestes moldes: “ (...) a moda das tartarugas exóticas começou um dia a fatigar. Os animais foram crescendo desmedidamente, a termos de ocupar todo o espaço dos aquários domésticos, embatendo à toa nos vidros, com risco de os partir e de perturbar o sossego íntimo das famílias. (Carvalho, 2010: 11).”. 
Eis, no nosso entender, o tema de toda a narrativa, o sossego de um locus amoenus que será quebrado por bichos estranhos que o invadem para habitá-lo, multiplicam-se e vêm à tona. A continuidade do crescimento desses emparedados (em aquários, apartamentos ou casas de repouso na Lagoa Moura) vivos, em uma solidão enclausurada, é perturbadora. À ameaça silente e ininterrupta das tartarugas soma-se um acontecimento aterrador: o grande massacre dos patos pelos falcóes do aeroporto e confirma-se a epígrafe mencionada há pouco, que expressa a ânsia por mudanças. Talvez seja o que se dê com os protagonistas da história, Bárbara e Arnaldo, confinados a si mesmos numa espécie de autoenclausuramento quelonídeo, esbarrando em suas próprias paredes, por detrás dos vidros de restaurantes (Carvalho, 2010: 73). Os protagonistas (se-lo-ão mesmo?), como tartarugas, mostram-se como "anima[is] tácticos, traz[em] no sangue a capacidade de dissimulação, ainda que seja $[\mathrm{m}]$ pacato $[\mathrm{s}]$ de maneiras e pouco imaginoso[s]." (Carvalho, 2010: 32).

Comparar Arnaldo, Bárbara e todas as gentes às tartarugas não é de todo um despropósito. $\mathrm{O}$ narrador do cronovelema indica o paralelo "Arnaldo não percebeu bem se o desabafo tinha que ver com a rejeição da tartaruga, ou com aquele declive, lento e inexorável, do seu casamento, a perder para o fim (...). (Carvalho, 2010: 26)" - o autor parece confirmar essa noção na já citada entrevista a Luísa Costa Gomes. Para o autor, Arnaldo e Bárbara são

Dois perdedores. Náo têm perspectivas nenhumas, não têm aspiraçáo nenhuma e estáo num patamar diferente do dos pais, ali da Avenida de Roma, que tinham pelo menos aspiraçóes de cultura; não querem nada da vida, são pessoas baças e desinteressantes, embora não sejam maus tipos. ${ }^{4}$

o que, ao fim e ao cabo, resume a nossa atual condição humana. Ainda na mesma entrevista o escritor completa:

A Arte de Morrer Longe náo é sobre os grandes heróis do passado, nem sobre deuses mas... é sobre esta gente, que é pobre gente. Já estamos saturados de heróis no nosso tempo. Tivemo-los, e no que é que isso

4 In http://www.homemmag.pt/pt/index.php/arte-e-literatura/arquivo-arte-literatura/87-luisa-costa-gomes-entrevista-mario-de-carvalho Criado em 25 julho 2012 19:16 
deu? O que deu o sobre-humano? Desconfio cada vez mais dos heróis. Dos heróis e das construções que são feitas à sua volta...

Sem qualquer glamour, palavra que na obra virou nome de revista (Carvalho, 2010: 70), resta-nos a máxima final proferida por Bárbara: "Enfim, somos humanos, não?" (Carvalho, 2010: 124); sim, humanos, mas estamos como "uma massa flutuante" que "desliza para cima e para baixo, nas escadas rolantes" (Carvalho, 2010: 73)

E aí está como as circunstâncias da tartaruga reclusa, no seu exíguo compartimento, desimpedida de movimentar os membros, a cabeça, e de embater contra as paredes do aquário, evocam a condiçâo humana, livre de esbracejar dentro dos limites, mas apenas pressentindo, sem os compreender, e sem atingir as suas verdadeiras naturezas, as vozes, os rumores e os relampejos que há em volta. (Carvalho, 2010: 89)

O parágrafo é precioso: desconstrói e retoma, com outro formato, a alegoria da Caverna de Platáo. Aliás, este motivo, como afirmamos, retorna regular e diversamente no corpus carvalhiano, repete-se ora estendido, ora mais resumido. Em Era bom que trocássemos umas ideias sobre o assunto, uma caverna resguarda o professor de grego no $12^{\circ}$ andar de um prédio de apartamentos ao Lumiar, enquanto o Partido, mais uma caverna possível, mantém Joel Strosse como um cego maltrapilho no mundo "de fora" seco e sem alma (Carvalho, 2003: 150, 208). Gustavo, em $A$ sala magenta (Carvalho, 2008: 27), recluso, "encostou-se ao parapeito da janela e espreitou o soturno encastelar de massas negras da floresta, que pareciam aguardar o momento distraído em que a débil luz de presença lhes desse campo. Eram retesas sombras de ameaça cercando ao perto como presenças malignas a tentear os restos duma fogueira." Mas das cavernas hodiernas não vamos falar.

Carece voltar ao método proposto, recuperar a página das epígrafes e considerar a primeira delas: "This world surely is wide enough to hold bother thee and me", um dito de Lawrence Sterne. Será que o romancista irlandês tem razão? Há, verdadeiramente, lugar bastante para todos no mundo? Os patos, logo nas primeiras páginas de Mário de Carvalho, foram dizimados tal qual aqueles da homérica Penelope; a tartaruga será igualmente arrebatada por um milhafre. Em A Sala Magenta, Gustavo, que provavelmente seria vizinho de Arnaldo, cujo nome remete à águia, e Bárbara, cujo nome dispensa tradução, lá pelas bandas da Lagoa Moura, 
padece do mesmo tédio e se sente atraído pela "superfície de vidro escuro da lagoa" até que "decidiu que a única forma de escapar ao terror era entrar nele" (Carvalho, 2008, 175). Há lugar para todos com seus imensos medos? O casal lisboeta, que será dele?

De Arnaldo e Bárbara não saberemos, por enquanto, no "enquanto do livro". Eles ficarão juntos do início ao fim, atados por minúsculos problemas que crescem aos seus olhos; caminharáo isolados, na vaga e doce tristeza de Lisboa, estarão entre a "macieza derramada de musgos"; a "dolência abandonada"; a "espessura das águas limosas" (Carvalho, 2010: 11-12) até a "negrura inquietante" da Lagoa Moura com o ar "denso, esfriado, e bafento", o "pesadume do ambiente" com um "toque de sinistrude" (Carvalho, 2010: 122-123). Deles saberemos apenas que o assunto termina como começou: na placidez e na quietude harmoniosa de um livro eles vivem encerrados e contemplando a evoluçáo profética do texto que se consome num ato de violência natural, o massacre dos patos, o arrebate da tartaruga. Mário de Carvalho, com esta grande alegoria, "tem a intuição de dispor coisas no terreno, de prever lances, como um matemático genial"s. Tratando do aquário, do apartamento ou da Casa Moura, de Lisboa, de Portugal, do Brasil (e de seus brasileiros barulhentos, 23; feiticeiros, 60; ameaçadores, 86), dos ucranianos, dos Centro-Americanos exportadores clandestinos de tartarugas, dos africanos... ele fala, enfim, do lugar que, exilados (ou seria desolados?), habitamos. Do lugar de nós mesmos que nos é revelado pelo "outro" (o de fora da caverna e igualmente o de dentro, que está no íntimo de nós). Entretanto, a situação de um outro nos deixa aterrados (Cf. fala do narrador em Carvalho, 2011: 62), como o escritor, um tanto quanto acerbamente, argumenta:

Bem, quando eu nasci, o país náo era grande coisa. Por um lado, quer queiramos quer não, estamos muito melhor, demos um salto. Quando se saía daqui é que se percebia, antes da revolução, o fosso tremendo que havia. Quando cheguei à Suécia, apercebi-me disso. Agora, o país foi tomado por gente que se tem aproveitado dos recursos nacionais em proveito próprio e caímos nas mãos da velha chatinagem, da velha veniaga e não há meio de se sair disto. Náo estou só a falar desta última crise, estou a falar desta gente que se tem instalado com muitas cumplicidades, ano após ano, em trinta e seis anos de democracia. (...)

5 In http://www.homemmag.pt/pt/index.php/arte-e-literatura/arquivo-arte-literatura/87-luisa-costa-gomes-entrevista-mario-de-carvalho Consultado em 25 agosto 2012. 
É uma situação que me preocupa muito, porque não vejo saídas, e se as antevejo elas são catastróficas, dramáticas. Mas se me pergunta, nunca supus, de facto, que depois daquela exaltação e daquela euforia do 25 de Abril houvesse esta implantação de negociantes que só pensam em si próprios. Não têm nada que ver com o destino da Pátria. E a quem a própria ideia de interesse público é estranha. ${ }^{6}$

E a história de placidez e fúria de Arnaldo e Bárbara, de Lisboa e Portugal, do tempo em que estamos vem abraçada pelas orelhas largas da capa que, à frente, traz um excerto do livro: "Querida Bárbara, não seria bem tua amiga se não te pusesse ao corrente. Ele tem outra... - O meu Arnaldo? Achas? - Fatal como o destino." (Carvalho, 2003: 60); e que atrás exibe uma foto do largo sorriso de Mário de Carvalho com uma relação de suas obras abaixo do retrato.

Como se unem a traição trágica, a intrusão do outro que destaca o autor, no trecho citado, a fatalidade e o destino de Bárbara e o riso matreiro e colorido de um escritor feliz? Por que uma capa em preto e branco e um relampejo de cores no final? $\mathrm{O}$ que significa o aspecto externo, o aspecto "morfológico" (mas igualmente discursivo) destes textos de acompanhamento? O que eles dizem a respeito da obra? Simploriamente falando: começamos pelo pesadume de uma traição e acabamos no riso bem-humorado do autor; ou, em outros termos,

É a sina dos homens serem sistematicamente traídos pelos caprichos da realidade. Ainda que advertidos por qualquer Cassandra da marcha das coisas, não deixariam de proceder às cegas, como é próprio da sua natureza, servil a um destino escrito não sei onde. (Carvalho, 2010: 13)

Ao que parece, estamos todos na caverna platônica e somos constantemente "traídos pelos caprichos da realidade", "andamos às cegas", confinados ou afundados em águas escuras. Não obstante, "sabe, meu amigo, a questáo é que se tomamos as coisas muito a sério corremos o risco de as coisas nos tomarem a sério a nós"7 ou ainda, recuperando Gil Vicente,

6 In http://www.homemmag.pt/pt/index.php/arte-e-literatura/arquivo-arte-literatura/87-luisa-costa-gomes-entrevista-mario-de-carvalho Criado em 25 julho 2012 19:16

7 A citação é uma das epígrafes da obra Contos da sétima esfera, de Mário de Carvalho, o qual, por sua vez, cita sua autoria deste modo: "[Habitual reflexão do Capitão Andrade do conto "Que todos ficassem bem", que não se sabe porquê, não vem registrada.]" 
talvez o autor diga: "De que me rio? Rio-me de mil coisinhas, nanja vossas, senão minhas." Portanto, o riso zombeteiro do autor nos faz encarar o seu discurso literário - e o nosso tempo ali representado - com atitude lúdica ou pelo menos, fisicamente descontraída. Nossa única saída para enfrentar a carga da história contemporânea (de Arnaldo, Bárbara, da tartaruga e de nós próprios) está em cultivar o bom humor, uma espécie de deus-ex-machina da atualidade. ${ }^{9}$

Sem embargo, construído através de uma intertextualidade complexa, disfarçada, aludida e plural, o texto carvalhiano, quanto ao riso como saída, se contradiz em denúncia amarga. Incomoda-o a inversão social, moral e ética dos nossos tempos. ${ }^{10} \mathrm{O}$ riso não basta. $\mathrm{O}$ exercício da autocrítica parodística para a superação dos problemas vem crivado de indagaçôes e, em geral, do lúdico, fantasioso e utópico o sentido se desloca para o preciso, realista, objetivo, funcional, prático e cáustico, de modo a revelar o que Rodrigues Lopes (2003: 22) chama de se adaptar "às condiçóes institucionais dominantes e ao mercado" sem sucumbir e produzir simples objetos de consumo como qualquer outro artigo de supermercado. O livro que se fecha traz uma contracapa branca, sem palavras, com apenas o selo da editora, marca da "coisa" publicada.

Encontram-se na desconstrução $A$ arte de morrer longe, Fantasia para dois coronéis ${ }^{11}$ e Era bom que trocássemos umas ideias sobre o assunto. Esse último, ao contrário da Lisboa bucólica, urbe das urbes, materializa, por metonímia, a sua demolição, focalizando a implosão de velhos prédios. As explosôes iniciais dão uma abertura bombástica e melancólica, a tal ponto que, "na página dezoito, em atraso sobre o momento em que os teóricos da escrita criativa obrigam ao início da acção", o narrador se vê "obrigado a deixar para depois estas desinteressantes e algo eruditas consideraçóes sobre cores e arquiteturas, para passar de chofre ao movimento, ao enredo." (Carvalho, 2003: 18). O trecho, embora pontual, é exemplar e simbólico. A menção do número da página que avança em assuntos supostamente

8 Epígrafe de Casos do beco das sardinheiras.

9 Para refletir sobre o estratagema do deus ex-machina como solução das afliçóes ordinárias, confira-se A arte de morrer longe, 44-45.

10 Baseamo-nos, principalmente, no tratamento dado a Maria Eduarda e Cláudio em Era bom que trocássemos umas ideias sobre o assunto; em Coriolano no objeto de nosso estudo.

11 Sobre essa obra, na entrevista a Luísa Costa Gomes, Mário de Carvalho afirma ser ela um cronovelema. A edição, na capa, carateriza-a como romance. No interior do livro, 4, o autor afirma: "Este em que flanamos - chamamos-lhe cronovelema - propóe-se a narrar". 
alheios à história, não obstante a urgência de um fluxo narrativo, extrapola o texto e exige um cuidado editorial para com esse pormenor, o qual nos serve para mostrar a movência lúdica e simbólica que o autor projeta e produz em sua obra. O estratagema nos faz lembrar o "amanhâ" e o "longe" antes comentado. Ao citar a página, a narrativa vem, necessariamente, atrelada ao seu veículo material e o diálogo com o leitor, para que se faça verossímil, deve ser corrigido, caso uma nova edição mude a página da frase. O recurso é repetido, ainda no mesmo parágrafo: "Na página três já deveria haver alguém surpreendido, amado, ou morto. Falhei a ocasião de 'fazer progredir' o romance. Daqui por diante, eu mortes e amores, não prometo, mas comprometo-me a tentear algumas surpresas." (Carvalho, 2003:18) e a ele acrescenta-se a promessa de maior zelo e de novas condutas.

Ora, o fracasso anunciado não se confirma. Quando pensamos que a embarcação de Carvalho coloca a narrativa à caceia (como sugere o próprio autor), nos enganamos. O vento criativo bate na popa, enche a vela e o cronovelema avança, discutindo náo somente a descontrução do patrimônio arquitetônico, mas também da demolição do patrimônio literário, cultural, moral, ético e, sobretudo, político. Ridendo castigat mores? Pelo menos é o que se sente e pensa ao fim, nos dois últimos parágrafos.

Uma ocasiáo, Jorge Matos encontrou-o e dirigiu-lhe pela quinquagésima vez a pergunta que todos os comunistas de todo o Mundo ja se fizeram, no íntimo, pelo menos quatrocentas vezes: "que significa ser comunista, hoje? Vitorino recolheu-se, sisudo, durante um momento brevíssimo. Depois, abriu um sorriso jovial, de orelha a orelha, e deu-lhe uma palmada sonora nas costas: “É pá, tem calma, pá!", disse.

E o Tejo continuou a correr, e os tempos a náo haver meio de os parar. (Carvalho, 2003: 213).

Por certo, ao fim do livro tem-se que esvaiu-se o valor político de ser comunista, tal como no início do livro "fizeram implodir um velho prédio de estilo dito de Munique"; mas, igualmente, tal como o edifício da Fundaçáo Helmut Tchang Gomes resistiu pacatamente, patrocinando concertos e recitais de poesia, assim também o "Tejo continuou a correr".

A abertura de Fantasia para dois coronéis tem também frases de efeito - de modo a causar pasmo - que nos dirigem para o mesmo caminho de busca pelo novo que acaba no frenesi da tagarelice: "O país quer aturdir-se. (...) Passam-se dias, meses, anos, remoem as depressóes, adejam os perigos e o país a falajar, falajar, falajar." (Carvalho, 2003: 11-12). Organicidade, 
desejo de narrar e unidade nos levam a pensar em encaixar estas obras no gênero "romance". No miolo de toda a história muitas outras coisas se deram acerca de destruiçóes e construçóes para que tudo transcorra de acordo com o plano narrativo anunciado na página $14 \mathrm{em}$ Era bom que trocássemos umas ideias sobre o assunto:

Sempre que em Lisboa se constrói um prédio de estilo, com prosápia inovadora, cai Troia, caem o Carmo e a Trindade, caem dirigentes políticos, caem reputaçóes, as ondas sonoras dos desmoronamentos imaginários ressoam, vibram, enervam, insistem, maçam e só o que não cai é o edifício em causa, como não caiu este.

O programa estabelecido nas primeiras páginas e especificamente neste parágrafo pode ser lido sob a regência da expressão "desmoronamentos imaginários", que abre espaço para a possibilidade de se lerem muitas outras intenções, no mesmo trecho, de forma metafórica, a saber, "um prédio de estilo"; "prosápia inovadora"; "cai Troia"; "vibram, enervam, insistem, maçam e só o que não cai é o edifício em causa, como não caiu este". Expressóes análogas, a remeter para o universo da desconstrução, ocorrem igualmente em $A$ arte de morrer longe: "caiu Troia" (41); "uma enorme cadeira de balouço" com "o assento estava desentrançado, há anos, num eriçamento caótico" (81); "de posse da cadeira, a mãe a rir, e ruídos de madeira a estalar" (82); "uma fúria de ventos" obrigou um pinheiro a largar; "uma rija pernada sobre o telhado da velha-vivenda-de-passar-férias-e-trocar-deaborrecimentos" (35).

Em Era bom que trocássemos umas ideias sobre o assunto a passagem citada termina com duas situaçóes de uso de dêiticos: "o edifício em causa" - que nos aponta para o prédio da Fundação Helmut Tchang Gomes - e o demonstrativo "este", mecanismo sintático-lexical que alarga a leitura do segmento citado no sentido de podermos lê-lo como um programa de construção de um prédio qualquer ou de um prédio específico, aquele que erige um edifício de estilo, um edifício literário. Da mesma forma podemos ler a destruição da cadeira avoenga, "uma relíquia de família". Semelhanças à parte, queremos somente marcar que Carvalho é profeta de nosso tempo, alguém que fala aquilo que não se pode falar. Suas obras não "falam de"; trata-se de uma fala que recusa a normalidade e que assimila a vagância, que admite que nem tudo esteja condenado a situar-se diante de nós como objeto (Lopes, 2003: 192-193). Começamos nossa análise pelo livro-objeto e chegamos ao silêncio de uma contracapa em branco; encontramo-nos no vazio de todos nós. 
Assim, as inflexões e desvios, as incompreensões e intimidades partilhadas pela leitura definem nossa relação com a complexidade da obras do escritor lisboeta. Admitimos as imprecisóes e segredos (alguns guardados, outros revelados) e admiti-los "é admitir que é a própria relação que faz vacilar a distinção entre leituras correctas e leituras erróneas e que o segredo ou vazio que suspende a apropriação ou uso desse tipo de textos (a que chamamos literatura) é uma força activa, desencadeadora do sentir-pensar."12 Não houvesse segredo, não escreveríamos sobre a obra. Mas

[n]a noite da desconstrução, todos os gatos são pardos. Não joguemos com as palavras: a verdade absoluta talvez não exista - e no entanto o assassinato dos judeus é uma verdade, não uma interpretação; o bem puro seguramente não é deste mundo, mas não é realmente indiferente saber que De Man sugeriu uma "solução para o problema judeu" através da deportação e saudou a chegada de Hitler, como "a conduta perfeita de uma invasão altamente civilizada" (os soldados alemães na França). A atitude aparentemente humilde de Hartman e dos outros desconstrucionistas ("nada é seguro") parece-me, na realidade, esconder o desprezo por todos os que aspiram a um pouco mais de justiça e de verdade. Enquanto se trata de palavras, o anti-humanismo pode parecer sedutor; convertido em atos, é inadimissível. Que caminho entâo permanece aberto (...)? (Todorov, 1999: 205)

E para que nos serviu este pequeno livro, literatura light a tratar de tema tão pesado? Precisamos de uma ars moriendi para este nosso tempo, que busca perpetuar a juventude e prolongar a morte de todos. Sem dúvida, a reflexão sobre a obra levou-nos a consideraçôes de ordem mais abrangente, como a relaçáo do pesquisador com o conhecimento e mais particularmente o conhecimento deste bicho humano que somos. Conhecer o humano para ensinar o humano a viver como um outro que provoca confrontos interiores e exteriores, isto é preocupar-se com cavernas pulmonares, cardíacas, ventrais.

Seria isso a desindividuaçáo? Desculturação? Seria possível viver-se fora da cultura ou, em outro sentido, seria possível viver numa determinada cultura sem se aculturar? Talvez a perturbaçáo que transpira do texto de Mário de Carvalho e a sua vasta quantidade de publicaçóes digam-nos da consciência de que fala Todorov: "Se perco meu lugar de enunciação, não posso mais falar." (Todorov, 1999: 20-21).

12 Rodrigues Lopes, 2003: 19. 
O escritor português está certo de seu lugar de enunciação e sabe o que fala. Sem valores, estamos fadados a sermos desconstrutores de formas canônicas de viver e pendemos para um falatório sem fim, causa de inúmeros despautérios. É possível que sim; isso indica o narrador de Fantasia para dois coronéis e uma piscina: "Assola o país uma pulsão coloquial que pốe toda a gente em estado frenético de tagarelice, numa multiplicação ansiosa de duos, trios, ensembles, coros." (Carvalho, 2003: 11). Contudo, "[t]oda ruptura e toda cisão não são uma fatalidade" e "nenhum entrave deve impedir a busca da verdade." (Todorov, 1999: 23). Não há regra senão a transparência" e "a pior revelaçáo vale mais que a suspeita e a incerteza" (Todorov, 1999: 76); louva-se, como avalia o pensador búlgaro, a pluralidade das culturas, a mistura das vozes, a polifonia desmedida, que não conhecem hierarquia nem ordem; talvez seja por isso que se reconhece o cosmopolitismo, o nomadismo, "quadro apropriado para o sujeito descentrado que seria cada um de nós.” (Todorov, 1999: 24).

A desumanização de nosso tempo; a deriva afetiva, geográfica e intelectual; o plurilinguismo, o cosmopolitismo, o desenraizamento, o conhecimento pelo conhecimento, a arte pela arte não saciam. $\mathrm{O}$ conforto e o repouso não trazem felicidade, "o hedonismo não é imoral, é falso" (Todorov, 199: 185); o que nos resta, senáo encarar as diferenças, descentrar-se, enriquecer o espírito, vergar o ego, aprender a tolerância e amar? Isto é verdadeiro, é real, é porto seguro para atracar a alma. Acreditamos que só isso explica a dedicatória de Fantasia para dois coronéis e uma piscina, "Aos meus netos João, Miguel, Mariana e Mário."; e a de $A$ arte de morrer longe, "Às minhas filhas Ana Margarida de Carvalho e Rita Taborda Duarte"; e a de A inaudita guerra da avenida Gago Coutinho, "Aos meus pais"; e a de Contos da sétima esfera, "À Lena, sempre e ao Fernando Guerreiro que me animou a escrever estes contos; e a de Casos do beco das sardinheiras, "Às minhas filhas Ana Margarida e Rita e aos Quatro Elementos Editores”; dedicatórias que vão do familiar ao profissional.

Por fim, resta-nos apenas marcar que a esperança e o sorriso em Mário de Carvalho nos fazem lembrar - seja pelo léxico, seja pelo envolvimento violento e amoroso entre as personagens - o conto de Jorge de Sena, Homenagem ao papagaio verde, ${ }^{13}$ o que nos dá mais um tema para tese. Que seja! Afinal, a tartaruga como o papagaio, não tinha nome, só o substantivo simples que denomina a espécie e "a posse desses seres tấo exóticos, portadores prováveis e espontâneos de uma doença estranha" (Sena, Homenagem

13 http://www.letras.ufrj.br/lerjorgedesena/port/antologia/ficcao-e-teatro/texto.php?id=319 
ao papagaio verde, cf. nota 13), eles são seres para os quais precisamos de luvas para transportar (Carvalho, 2010: 23), todavia, podem ser eles a nossa salvação afetiva; saber que criaturas "tão caprichosas e volúveis, tão imprevisíveis, tão ilógicas, tão hipocritamente cruéis" (Homenagem ao papagaio verde) se preocupam em se desvencilhar de problemas buscando um lugar adequado para uma tartaruga e, com a humana crueldade de sempre, fornecem material para se tecer um cronovelema. Por isso, "[a]pesar do pânico, da confusão, dos espasmos e do escuro, Gustavo reparou que a rapariga tinha a alçado sutiã descaída e um mamilo afunilado, que talvez fosse muito rosado e tenro" (Carvalho, 2008: 175)... Em outras palavras, apesar do medo e da confusão, há um corpo concreto que nos impede de afundar; afinal, somos humanos, não? 


\section{Bibliografia Geral}


(Página deixada propositadamente em branco) 


\section{Ediçôes de Mário de Carvalho}

(21990), Contos da sétima esfera. Lisboa, Caminho.

(1991), Quatrocentos mil sestércios. Lisboa, Caminho.

(71991), Casos do beco das sardinheiras, Lisboa, Caminho.

(31993), A Paixão do Conde de Fróis. Lisboa, Caminho.

(1996), Os Alferes. Lisboa, Caminho.

( $\left.{ }^{3} 1996\right)$, O livro grande de Tebas, Navio e Mariana. Lisboa, Caminho.

(1997), Um deus passeando pela brisa da tarde, Lisboa, Caminho.

$\left({ }^{3} 1997\right)$, Fabulário. Lisboa, Caminho.

(52003), Era bom se trocássemos umas ideias sobre o assunto. Lisboa, Caminho.

(32004), Fantasia para dois Coronéis e uma Piscina. Lisboa, Caminho.

('2006), A inaudita guerra da Avenida Gago Coutinho. Lisboa, Caminho.

(2008), A sala magenta. Lisboa. Caminho.

(2010), A Arte de Morrer Longe. Lisboa, Caminho.

\section{Estudos}

Adorno, T. W. ('1983), "Posição do narrador no romance contemporâneo". In: Benjamin, Honkheimer, Adorno, Habermas. Trad. port. José L. Grünnewald et alii. São Paulo, Abril Cultural: 269-273.

Albaladejo, T. (1986), Teoría de los mundos posibiles y macroestructura narrativa. Alicante, Universidade de Alicante.

Albaladejo, T. (1992), Semántica de la narración: la ficción realista. Madrid, Taurus.

Albérès, R. M. (1972), Métamorphoses du roman. Paris, Albin Michel.

Almeida, J. F. (1997), Bíblia Sagrada. Rio de Janeiro, Fecomex (Ed. Revisada e corrigida).

Alves, C. C. (2010) "Vestígios do trágico em Mário de Carvalho”. Navegaçôes 3. 1: 53-58.

Anacleto, M. T. (1996), “(Sub)versions du "cliché” romanesque au XVII siècle: le "roman bourgeois" de Furetière”, Confluências 14: 97-109.

Angelini, P. R. K. (2011) "Recensão de Carvalho, M. A arte de morrer longe. Lisboa, Caminho, 2010. 128p.”. Navegaçōes 4. 1: 131-133.

Arnaut, A. P. (2001), "Donas e donzelas n'a Demanda do Santo Graal”, Santa Barbara Portuguese Studies. Califórnia, n. 5: 29-71. 
Aristófanes (21989), A Paz. Tradução de Silva. M. F. Coimbra, Instituto Nacional de Investigação Científica.

Aristófanes (2006), As Aves. Tradução de Silva, M. F. Lisboa, Edições 70.

Aristóteles (1986), Poética. Tradução de E. Sousa. Lisboa, Fundação Gulbenkian.

Arnaut, A. P. (2002), Post-Modernismo no romance português contemporâneo. Fios de Ariadnemáscaras de Proteu. Coimbra, Almedina.

Assis, A. K. T. (2008), Arquimedes, o centro de gravidade e a lei da alavanca. Montreal, Apeiron Montral.

Auerbach, E (1976), Mimesis (A representação da realidade na literatura ocidental). São Paulo, Perspetiva [1 $1^{\text {a }}$ ed., 1946].

Aurélio, Marco (1971), Pensamentos. Versão de João Maia. Lisboa, Editorial Verbo.

Bakhtine, M. (1970), La Poétique de Dostoievsky. Paris, Éd. du Seuil.

Bakhtine, M. (1981), Dialogic imagination: four essays. Austin, University of Texas Press.

Bakthine, M. (1981), Problemas da poética de Dostoievski. Trad. port. Paulo Bezerra. Rio de Janeiro, Ed. Forense-Universitária.

Benjamin, W. (1985), "Sobre o conceito de História. Tradução de Sérgio Paulo Rouanet”. In: Obras escolhidas. Magia e técnica, arte e política. São Paulo, Editora Brasiliense: 222-232.

Bessière, J. (2010), Le roman contemporain ou la problemacité du monde. Paris, PUF.

Beye, C. R. (1964), "Homeric battle narrative and catalogues", Harvard Studies in Classical Philology 68: 345-373.

Bergson, H. (2001), O riso: ensaio sobre a significação da comicidade. Trad. port. Ivone C. Benedetti. São Paulo, Martins Fontes.

Bhabha, H. K. (1998), O local da cultura. Belo Horizonte, Editora UFMG.

Bianchet, S. B. (2004), Petrônio. Satyricon. Edição bilíngüe. Belo Horizonte, Crisálida.

Bougnoux, D. (1991), "Le principe d'identification”. In Personnage et Histoire Littéraire. Toulouse, Presses Universitaires du Mirail: 187-195.

Brandão, J. L. (2001), A poética do Hipocentauro: Literatura, sociedade e discurso ficcional em Luciano de Samósata. Belo Horizonte, Ed. UFMG.

Brasete, M. F. (2003), “A crítica às mulheres no fr. 7 de Semónides de Amorgos”. In: Mora, C. M. (ed.), Sátira, Paródia e Caricatura: da Antiguidade aos nossos dias. Aveiro, Universidade de Aveiro: 39-56.

Brauner, E. F. (2009), “" Era bom que trocássemos umas ideias sobre o assunto”: ironia de um narrador e discussão do romance", Revista Electrónica de critica e teoria de literaturas. Dossiê: o romance português e o mundo contemporâneo 5. 2. Porto Alegre: 1-9.

Buescu, H. (1995), A Lua, a Literatura e o Mundo. Lisboa, Cosmos. 
Buescu, M. L. C. (1979), Aspectos da herança clássica na cultura portuguesa. Lisboa, Instituto de Cultura Portuguesa.

Camôes, L. (1979), Os Lusíadas. Prefácio de Hernâni Cidade. São Paulo, Abril Cultural.

Carcopino, J. (1993), La vida cotidiana en Roma en el apogeo del imperio, trad. esp. Madrid, Ediciones Temas de Hoy.

Cardoso Bernardes, J. A. (1988), O Bucolismo Português. A égloga do Renascimento e do maneirismo. Coimbra, Livraria Almedina.

Carvalho, M., (2003), "Mário de Carvalho: crónica do aturdimento". JL - Jornal de Letras, Artes e Ideias 864, 12/11: 12.

Ceia, C. (2007), A Construção do romance (Ensaios de literatura comparada no campo dos estudos anglo-portugueses). Coimbra, Almedina.

Chevalier, J., Gheerbrant, A. (1994), Dicionário dos Símbolos, trad. port., Lisboa, Editorial Teorema.

Colaço, J. (1995), “Mário de Carvalho”, Biblos. Enciclopédia verbo, I, s.u.

Compagnon, A. (2001), O demônio da teoria: Literatura e senso comum. Belo Horizonte, Editora UFMG.

Constâncio, N. (2007), Ruinas e incertezas em "Um Deus passeando pela brisa da tarde”, de Mário de Carvalho. Lisboa, Edições Colibri.

Costa, L. S. (1995), “Era Bom que Trocássemos Umas Ideias Sobre O Assunto, de Mário de Carvalho. A Arquitectura, A Violência”. In: Público/Leituras, 11 de Novembro:10.

Cotrim, J. P. (1996), Entrevista a Mário de Carvalho: "Alguma coisa me perturba”. Ler/Livros e Leitores 34: 45.

Cotrim, J.P. (1996), "Mário de Carvalho. O Mistério da Literatura”, entrevista ao autor. LER 34, Primavera.

Cristóbal, V. (1992), "Búsqueda de campo, hastío de ciudad. Pasión antigua y contemporánea”. In: Guzmán, A. et alii (ed.), Aspectos modernos de la Antigüedad y su aprovechamiento didáctico. Madrid, Ediciones Clásicas: 131-143.

Davison, M. (1976), "The thematic use of ekphrasis in the ancient novel”, in Erotica antiqua. Acta of the International Conference on the Ancient Novel. Bangor, ICAN: 32-33.

Devereux, G. (1975), Dreams in Greek tragedy. Oxford, Basil Blackwell.

Dijksterhuis, E. J. (1987), Archimedes. Translated by C. Dikshoorn. Princeton University Press.

Diogo, A. A. L. (1997), "Exórdio". In: Biblos- Enciclopédia Verbo das Literaturas de Lingua Portuguesa. Lisboa, São Paulo, Verbo.

D’Onofrio, S. (1978), Poema e Narrativa: estruturas. São Paulo, Duas Cidades. 
Duncan, T.S. (1935), “The deus ex machina in Greek Tragedy”. Philological Quarterly 14: $126-141$.

Dunn, F. M. (1985), Euripidian Endings: a Study of the Choral Exit, the Action, the Concluding Prophecy and the Deus ex Machina. Yale University: 111-167.

Eco, U. (1979), Leitura do Texto Literário. Lector in Fabula. Trad. Mário Brito. Lisboa, Presença.

Entrevista com Mário de Carvalho http://www.homemmag.pt/pt/index.php/arte-e-literatura/arquivo-arte-literatura/87-luisa-costa-gomes-entrevista-mario-de-carvalho

Ernout, A. ( $\left.{ }^{11} 1993\right)$, Pétrone. Le Satyricon. Paris, Les Belles Lettres.

Ernout A, Meillet, A. ( $\left.{ }^{4} 1967\right)$, Dictionnaire etymologique de la langue latine: histoire des mots. Paris, Librairie C. Klincksieck.

Errandonea, I. (1954), Diccionario del mundo clásico. Barcelona, Editorial Labor.

Eschilo ( $\left.{ }^{4} 2000\right)$ I sette contro Tebe. Con testo a fronte. Introd. Umberto Albini. Trad. Ezio Savino. Milano, Garzanti Editore.

Feijóo, B. (1998), Um Não Sei Quê. Lisboa, Vega [1746].

Ferreira, C. (2003), “Mário de Carvalho. A arte de bem iludir o leitor”. In: Rodapé: 45-51.

Ferreira, P. S. (1999), “A paródia e as suas implicações didácticas”. In: Torrão, J. M. N. (ed.), III Colóquio Clássico - Actas. Aveiro, Universidade de Aveiro: 113-137.

Ferreira, P. S. (2000), Os elementos paródicos no Satyricon de Petrónio e o seu significado. Lisboa, Colibri.

Ferreira, P. S. (2003), “Paródia ou paródias?”. In: Mora, C. M. (ed.), Sátira, Paródia e caricatura: da Antiguidade aos nossos dias. Aveiro, Universidade de Aveiro: 279-300.

Fialho, M. C. (1992), Luz e trevas no teatro de Sófocles. Coimbra, Instituto Nacional de Investigação Científica.

Figueiredo, M. N. (2006), "Com humana crueldade se tece um conto. A propósito de Homenagem ao Papagaio Verde”. In: Santos, G. (ed.) Jorge de Sena: Ressonâncias e Cinqüenta Poemas. Rio de Janeiro, 7Letras.

Fowler, D. P. ((1991), "Narrate and describe: the problem of ecphrasis", Journal of Rhetorical Studies 81: 25-35.

Frow, J. (1986), “Spectacle Binding: On Character”. Poetics Today 7. 2: 227-250.

Gaffiot, F. (1934), Dictionnarie Illustré Latin-Français. Paris, Librairie Hachette.

Garrett, A. (1973), Viagens na minha Terra. Rio de Janeiro, Editora Três.

Genette, G. (1972), Figures III. Paris, Ed. du Seuil.

Gennete, G. (1997), L'Cuvre de l'Art. La Relation Esthétique, II. Paris, Ed. du Seuil.

Genette, G. (2004), Métalepse. Paris, Ed. du Seuil.

Gomes da Torre, M. (1992), “Acerca da tradução da metáfora”. Linguas e Literaturas 9: 209-226. 
Grimal, P. (s/d), Dicionário de Mitologia Grega e Romana. Lisboa.

Guillén, J. (1977), Vrbs Roma - vida e costumbres de los romanos, vol. I: La vida privada. Salamanca, Ediciones Sígueme.

Guthrie, W. K. C. (1976), Les Sophistes. Paris, Payot.

Halliwell, S. (1968), Aristotle's Poetics. Chicago and London.

Hamon, P. (1976), “O que é a descrição?”. In: Seixo, M. A. (ed.), Categorias da narrativa. Lisboa, Arcádia: 61-83.

Hardwick, L. (2003), Reception Studies. Greece and Rome. New Surveys in the Classics. Oxford, Oxford University Press. [recensão do livro por Martin M. Winkler, in Bryan Mawr Classical Review 2004].

Heródoto. (2002), Histórias. Livro I. Tradução de Ferreira, J. R., Silva, M. F. Lisboa, Ediçóes 70. Heródoto (1997), Histórias. Livro III. Tradução de Silva, M. F., Abranches, C. Lisboa, Ediçóes 70. Heródoto (2000), Abranches, C., Histórias. Livro IV. Tradução de Silva, M. F., Abranches, Lisboa, Edições 70.

Homero (2003), Odisseia. Tradução de Frederico Lourenço. Lisboa, Livros Cotovia.

Homero (2005), Ilíada. Tradução de Frederico Lourenço. Lisboa, Livros Cotovia.

Hoorn, J. F., and Konijn, E. A. (2003), "Perceiving and experiencing fictional characters: An integrative account”. Japanese Psychological Research 45. 4: 250-268.

Horácio (1975), Arte Poética. Tradução de R. M. R. Fernandes. Lisboa, Clássica Editora.

Hutcheon, L. (1977), “Modes et formes du narcisisme littéraire”. Poétique 29: 90-106.

Hutcheon, L. (1984), Narcissistic Narrative. The Metafictional Paradox. New York and London, Methuen.

Hutcheon, L. (1985), A Theory of Parody. The Teachings of Twentieth Century Art Forms. New York \& London, Methuen; (1989), Uma teoria da paródia, trad. port. Lisboa, Ediçóes 70.

Hutcheon, L. (1988), A poetics of Postmodernism. History, Theory, Fiction. New York/London, Routledge; (1991), Poética do Pós-Modernismo. Trad. Ricardo Cruz. Rio de Janeiro, Imago.

Hutcheon, L. (2000), Teoria e Política da Ironia. Trad. port. Julio Jeha. Belo Horizonte, Editora UFMG.

Immerwahr, H. R. (1966), Form and thought in Herodotus. University of North Carolina.

Izaac, H. J. ( ${ }^{3} 1969$, 1973), Martial. Épigrammes, I-II. Paris, Les Belles Lettres.

Jauss, H. R. (1986), Experiencia y Hermeneutica Literaria. Ensayos en el campo de la experiencia estétca. Madrid, Taurus, [1977].

Jenny, L. (1979), "A estratégia da forma”, Poétique. Revista de teoria e análise literárias. Trad. port. Clara C. Rocha. Coimbra, Almedina: 5- 49. 
Jerome, K. J. , “Three men on the Brummel'. In: http://www.gutenberg.org/catalog/world/ readfilefk_files $=2061881$

Jourdan, P. (1996), "Paul Valéry chasseur de perroquets", Confluências 14: 51-59.

Júdice, N. (1997), Viagem por um século de Literatura Portuguesa. Lisboa, Relógio d'Água.

Julien, Y. (1998), Aule-Gelle. Les nuits attiques, IV. Paris, Les Belles Lettres.

Jurado, F. G. (1999), "Apuntes para una historia prohibida de la literatura latina en el siglo XX: La voz de los lectores no académicos”. In: Morán, M. C. A.; Iglesias Montiel, R. M. (eds.), Contemporaneidad de los clásicos en el umbral deI tercer milenio. Actas deI Congreso Internacional Contemporaneidad de los clásicos: La tradición greco-latina ante el siglo XXI. La Habana, Universidad de Murcia: 77-85.

Kerferd, G. B. (2003), O movimento sofista. Trad. port. Margarida Oliva. São Paulo, Ediçôes Loyola.

Kirk, D. M. (1960), The digression, its use in prose fiction from the Greek romance through the eighteenth century. Stanford University.

Kristeva, J. (1974ª), Introdução à semanálise. São Paulo, Perspectiva.

Kuester, M. (1992), Framing Truths - Parodic Structures in Contemporary English-Canadian Historical Novels. Toronto/London, Toronto University Press.

Lausberg, H. (1963), Elementos de retórica literária. Trad. port. Raul M. Rosado Fernandes, Lisboa, Gulbenkian.

Leão, D. F. (1996), “Trimalquião: a humanitas de um novo-rico”. Humanitas 48: 161-182.

Leão, D. F. (1997), “Trimalquião à luz dos Caracteres de Teofrasto”. Humanitas 49: 147-167.

Leão, D. F. (1998), As Ironias da Fortuna. Sátira e Moralidade no Satyricon de Petrónio. Lisboa, Colibri.

Leão, D. F. (2004), “Zoilo e Trimalquião, duas variaçôes sobre o tema do novo-rico”. Humanitas 56: 191-208.

Leão, D. F. (2004a), “O Satyricon de Petrónio e a crise dos paradigmas tradicionais”. In: Nascimento, A. (ed.), Antiguidade Clássica: Que fazer com este património?. Lisboa, Centro de Estudos Clássicos: 233-242.

Leão, D. F. (2005), Petrónio. Satyricon. Lisboa, Cotovia.

Lepaludier, L (2002), Métatextualité et métafiction. Théorie et analyses, Presses Universitaires de Rennes, CRILA.

Levi, P. (1988), É isto um homem? Rio de Janeiro, Rocco.

Lévy, E. (1983), "Le théâtre et le rêve: le rêve dans le théâtre d'Eschyle", in Zehnacker, H. (ed.), Théatre et spectacles dans l'Antiquité. Actes du Colloque de Strasbourg. Leiden: 141-168.

Lopes, S. R. (2003), Literatura, Defesa do atrito. Lisboa, Copiart. 
Lourenço, E. ('1982), "Da literatura como interpretação de Portugal”. In O Labirinto da Saudade (Psicanálise Mitica do Destino Português). Lisboa, D. Quixote: 85-126.

Lourenço, F. (2003), Homero. Odisseia. Lisboa, Cotovia.

Luciano (1996), Uma história verídica. Tradução de C. Magueijo. Lisboa, Editorial Inquérito Limitada.

Lukács, G. (1989), Théorie du roman. Paris, Flammarion [1916].

"Na Lusitânia com Mário de Carvalho (História, paródia e ironia em Quatrocentos mil sestércios e Um deus passeando pela brisa da tarde)". In Veredas 5 (2002) 211-224.

Macedo, A. G. (2008), Narrando o pós-moderno: reescritas, revisôes, adaptaçôes. Braga Universidade do Minho.

Machado, J. P. (1995), Dicionário etimológico da Língua Portuguesa. Lisboa, Livros Horizonte.

Malina D. (2002), Breaking the frame: metalepsis and the construction of the subject. Columbus, Ohio State UP.

Margolin, U. (2005), “Character”. In: Herman, D., Jahn M., Ryan, M.-L. (eds.), Routledge Enciclopedia of Narrative Theory. London/New York, Routledge: 54-57.

Marinho, M. F. (1996), "O sentido da história em Mário de Carvalho", Revista da Faculdade de Letras. Linguas e Literaturas: 257-267.

Marinho, M. F. (2010), "À la recheche de l'identité perdue. Essai sur la crise d'identité dans le roman portugais contemporain”. In: Besse, M. G. \& Ralle, M. (eds.), Les Grands Récits: Miroirs Brisés? Paris, Índigo:186-198.

Martin, F. (1987), Les mots latins. Paris, Hachette.

Martins, J. C. O. (2011), "Mário de Carvalho e a reflexão metaficcional sobre o futuro do romance”. Diacrítica. Dossiê Literatura e Religiāo 25/3: 23-44.

Martins, J. C. O. (2011), “Pensar Portugal - ironia, paródia e desencanto: Mário de Cavalho e o retrato melancólico de um país". In: Carvalho da Silva, J. A., Martins, J. C. O., Gonçalves, M. (eds.), Pensar a Literatura no Séc. XXI. Braga, Univ. Católica Portuguesa: 463-478.

Martins, J. C. O. (s.d.), "La barbarie de l'ignorance dans la culture postmoderne et la fiction de Mário de Carvalho". In: De l'Extrême: pratiques du contemporain dans les mondes ibériques et ibéro-américains, Paris, CRIMIC [em publicação].

Martins, M. F. (1983), Sombras e transparências da literature. Lisboa, INCM.

Martins, Maria João (2003), "Mário de Carvalho: crónica de um aturdimento" [entrevista], JL - Jornal de Letras, Artes e Ideias, no 864, 12 novembro, p. 12.

Mead, G. (1990), “The Representation of Fictional Character”. Style 24. 3: 440.

Medeiros, W. (1997), "Do desencanto à alegria: o Satyricon de Petrónio e o Satyricon de Fellini”. Humanitas 49: 169-175. 
Melanda, P. C. O. (2001), Pela mão de Clio. A reescrita da História em Mário de Carvalho. Aveiro. 38. Dissertação de Mestrado em Estudos Portugueses, apresentada à Universidade de Aveiro. Exemplar em CDRom.

Melero Bellido, A. (2001), "La utopia cómica o los límites de la democracia”, Cuadernos de Literatura Griega y Latina 3: 7-25.

Melero Bellido, A. (2004), "La lengua de la utopia". In: López Eire, A., Guerrera, A. R. (Eds.). Registros Lingüísticos en las lenguas clásicas. Salamanca, Ediciones Universidad Salamanca: 149-172.

Mendes, A. M. G. (1999), "Cultura clássica em Um Deus Passeando pela brisa da tarde de Mário de Carvalho”, III Colóquio Clássico - Actas, Aveiro: 347-363.

Mendes, A. M. G. (2005), “Trimalquião, os coronéis e a piscina: retrato impiedoso de um país em crise”. Ágora. Estudos Clássicos em Debate. Aveiro 7: 129-150.

Mendes, J. P. (1997), Construção e Arte das Bucólicas de Virgílio. Coimbra, Almedina.

Mendonça, F. (1997), “A Paixão do Conde Fróis”. Colóquio/Letras 99. Setembro-Outubro.

Mexia, P. (2005), “O Manuel Germano”. Diário de Notícias. Artes, 17 de Junho: http:// dn.sapo.pt/2005/06/17/artes/o_manuel_germano.html

Moisés, M. ('1973), A criação literária: introdução à Problemática da Literatura. São Paulo, Melhoramentos.

Mora, C. M. (2003), “A outra resposta de Tirésias”. In: Mora, C. M. (ed.), Sátira, Paródia e caricatura: da Antiguidade aos nossos dias. Aveiro, Universidade de Aveiro: 7-13.

Morais e Silva, A. (1953), Grande Dicionário da Lingua Portuguesa. Lisboa, Confluência.

Mourão, J. A. (1998), "Posfácio”, a Feijóo, Benito - Um Não Sei Quê. Lisboa, Vega.

Nickel, R. (1999), “Lucian's True Story: impressions of a fancy voyage”, Euphrosyne 27: 249-257.

Niederauer, S. (2008), "Era bom que trocássemos umas ideias sobre o assunto ou $\mathrm{O}$ simulacro da narrativa na pós-modernidade”. Letras de Hoje 43. 4: 83-88.

Oliveira, B. S. (1997), Eurípides. Hipólito. Brasília, Editora UNB.

Onelley, G. B. (2004), “A resistência da nau: cidade na luta pelo poder”. Calíope 12: 33-42.

Otte, G. (1996), "Rememoração e citação em Walter Benjamin". Revista de Estudos de Literatura 4. Belo Horizonte, Centro de Estudos Literários (CEL), Faculdade de Letras da UFMG: 211-223.

Pereira, E. (2003), "Viagens na minha terra: ciladas da representação". Revista do Centro de Estudos Portugueses 23 n. 32: 61-68.

Pereira, S. M. (2008), “Poética dos sonhos e das visōes em estado de vigília - I”, Humanitas 60: 11-28.

Pereira, S. M. (2009), "Poética dos sonhos e das visōes em estado de vigília - II”, Humanitas 61: 5-18.

Perelman, C. O. (1993), O Império Retórico: Retórica e Argumentação. Tradução de Fernando Trindade e Rui Alexandre Grácio. Porto, Ediçóes Asa. 
Perrin-Naffakh. A.-M. (1996), "Le langage cliché: aveu d'usure ou pouvoir d'écho". Confluências 14: 7-14.

Perrone-Moisés, L. (1979), “A intertextualidade crítica”. Poétique. Revista de teoria e análise literárias. Trad. port. Clara C. Rocha. Coimbra, Almedina: 209-230.

Pimentel, C. S. (2001), "O latim nas literaturas portuguesa e francesa: instrumentos, métodos e agentes de ensino”, Ágora, Estudos Clássicos em Debate 3: 183-185.

Piwnik, M.-H. (1998), "Mário de Carvalho: crónica de um desfecho anunciado", Veredas 1, Porto: 317-325.

Piwnik, M.-H. (2004), “De Sienkiewicz a Mário de Carvalho: Duas construções da História”. In: Literatura e História. Actas do Colóquio Internacional, Porto, vol. II: 139-144.

Platão ( $\left.{ }^{12} 2010\right)$, República. Trad. Maria Helena da Rocha Pereira. Lisboa, Fundação Calouste Gulbenkian.

Préchac, F. (1987), Sénèque. Lettres a Lucilius, II. Paris, Les Belles Lettres.

Queirós, E. de (s./d.), Os Maias. Lisboa, Livros do Brasil.

Queirós, E. de (2000), O Crime do Padre Amaro. Ed. crítica de Carlos Reis e M. Rosário Cunha. Lisboa, IN-CM.

Rabaté, E. (1996), "Henri Michaux et le cliché: résistance et fascination”. Confluências 14: 61-75.

Raimond, M. (1989), Le Roman. Paris, Armand Colin.

Reis, C. (1996), "Mário de Carvalho. Incitação ao romance”. Jornal de Letras 28 Agosto: 22-23.

Reis, C. (1997), "Fábula”. In: Biblos-Enciclopédia Verbo das Literaturas de Lingua Portuguesa. Lisboa, São Paulo, Verbo: 462-463.

Reis, C. (2005), História crítica da literatura portuguesa, vol. IX (Do neorrealismo ao postmodernismo). Lisboa, Verbo: 287-318.

Reis, C., Macário Lopes, A. C. (72007), Dicionário de narratologia. Coimbra, Almedina.

Ricoeur, P. (1983), Temps et Récit. T.I. Paris, Ed. du Seuil.

Rio Torto, G. M. (1996), "Linguagem e clichê", Confluências 14: 159-175.

Robilliard, M.-A. (2002), Água em pena de pato de Mário de Carvalho. Um teatro do desencanto. Trad. port. Manuel Ruas. Lisboa, Editorial Caminho.

Rocha Pereira, M. H. (1955), Concepçōes Helénicas de felicidade no além: de Homero a Platão. Coimbra, Maranus.

Rocha Pereira, M. H. (1980), Poesia Grega Arcaica. Coimbra, Instituto de Estudos Clássicos.

Rocha Pereira, M. H. (1984), Estudos de História da Cultura Clássica, vol. II (Cultura Romana). Lisboa, Fundação Calouste Gulbenkian.

Rocha Pereira, M. H. ('1994), Romana - Antologia da Cultura Latina. Coimbra, Universidade de Coimbra. 
Rocha Pereira, M. H. ( $\left.{ }^{10} 2006\right)$, História da Cultura Clássica, I (Cultura Grega). Lisboa, Fundação Calouste Gulbenkian.

Rodrigues, L. G. (2005), “A Radioestesia”. In http://rprecision.logspot.com/2005/06/radiestesia.html Rose, M. A. (1979), Parody and meta-fiction. London, Croom Helm.

Sant'Anna, A. R. ('1985), Parodia, paráfrase \& cia. São Paulo, Ática.

Santos, R. B. (2009), Aspectos da Herança Clássica em Mário de Carvalho. Belo Horizonte, Faculdade de Letras da UFMG, 2009. [versão policopiada].

Saramago, J. (1989), História do Cerco de Lisboa. Lisboa, Caminho.

Saramago, J. (1990), "História e Ficção”. Jornal de Letras, Artes e Ideias, 6 de Março.

Schaeffer, J. M. (1992), L'art de l'àge moderne. L'esthétique et la philosophie de l'art du XVIIIème siècle à nos jours. Paris, Gallimard.

Schmidt, W. (1963), Der Deus Ex Machina bei Euripides. Tübingen University.

Schwartz, J. (1981), Murilo Rubião: A poética do Uroboro. São Paulo, Editora Ática.

Scodel, R. (1999), Credible impossibilities. Conventions and strategies of verisimilitude in Homer and Greek tragedy. University of Michigan Press.

Sedlmayer, S., "Sinais de fogo, aviso de incêndio: ideias estéticas, históricas e literárias em Jorge de Sena e Walter Benjamin”. In: Revista Literatrua e Autoritarismo. Dossiê Walter Benjamin e a Literatura brasileira. Santa Maria, Universidade Federal de Santa Maria/ RS. Disponível em http://w3.ufsm.br/grpesqla/revista/dossie05/art_02.php

Seel, M. (1992), "Le langage de l'art est muet". In: Bouchindhomme, Ch., Rochlitz, R. (eds.), L'art Sans Compas. Redéfinitions de l'Esthétique. Paris, Éd. du Cerf.

Segurado e Campos, J. A. (1991), Cartas a Lucílio, Lisboa, Fundação Calouste Gulbenkian.

Seixo, M. A. (1995), "Mário de Carvalho. Romance, Humanismo e BD”, JL - Jornal de Letras, Artes e Ideias, 12. 4: 24-25.

Sena, J. http://www.letras.ufrj.br/lerjorgedesena/port/antologia/ficcao-e-teatro/texto.php?id=319

Sequeira, M. G. R. (1996), Aproximação a uma Leitura do Risivel em A Paixão do Conde de Fróis. Tese de Mestrado apresentada à Faculdade de Letras da Universidade do Porto (dact.).

Settis, S. (2006), El futuro de lo 'clásico'. Traducción de Andrés Soria Olmedo. Madrid, Abada Editores.

Silva, M. F. (1987), Critica do teatro na comédia antiga. Coimbra, INIC.

Silva, M. F. (2005), Ensaios sobre Euripides. Lisboa, Cotovia.

Silva, M. F. (2007), "A porta na comédia de Aristófanes: uma entrada para a utopia”. In: Ensaios sobre Aristófanes. Lisboa, Cotovia: 257-274. 
Silva, M. F. (2008), "Mensagens, cartas e livros no teatro grego antigo", in Matos, M. C. (ed.), Helénicos. Estudos em homenagem do Prof. Jean-Pierre Vernant (1914-2007). Lisboa, Ediçôes Távola Redonda: 227-260.

Silva, M. F. (2009), Utopias e distopias. Coimbra, Imprensa da Universidade.

Silvestre, O. M. (1998), "Mário de Carvalho: Revolução e Contra-revolução ou um passo atrás e dois à frente”. Colóquio/Letras 147/148: 209-229.

Silvestre, O. e Diogo, A. L. (1998), "Entrevista a Mário de Carvalho", in <http://www. ciberkiosk.pt>, arquivo, $\mathrm{n}^{\circ} 1$ (15 pp.).

Simões, M. J. (2006), “Atrevidas e desbordantes: as personagens em Mário de Carvalho”. In Figuras da Fiç̧ão. Coimbra, Centro de Literatura Portuguesa: 79-92.

Spivak, G. Ch. ('2003), “Can the subaltern speak?” In: Asheroft, B., Griffith, G., Tiffin, H. (eds.), The post-colonial studies reader. New York, Routledge.

Spivak, G. Ch. (1998), "Puede hablar elsujeto subalterno?”. Orbis Tertius 3. 6: 1-44.

Sterne, L. (1860), The Works of Lawrence Sterne. London, Henry Bohn.

Thomasson, A. (2003), "Fictional Characters and Literary Practices". British Journal of Aesthetics 43. 2, April:138-157.

Todorov, T. (1999), O homem desenraizado. Trad. Christina Cabo. Rio de Janeiro, Record.

Torrão, J. M. N. (ed.) (1999), III Colóquio Clássico. Aveiro, Universidade de Aveiro.

Tosi, R. (2000), Dizionario delle sentenze latine e greche. Milano, Biblioteca Universale Rizzoli.

Trindade, L. (2004), “Os excessos de Abril”, História 65: 20-31.

Valente, A. M. (2004), Aristóteles. Poética. Lisboa, Gulbenkian.

Várzeas, M. (2001), Silêncios no teatro de Sófocles, Lisboa, Cosmos.

Villeneuve, F. (1970), Horace. Odes et Epodes, I. Paris, Les Belles Lettres.

Xavier, L. G. (2007), O discurso da ironia. Lisboa, Novo Imbondeiro.

Walton, K. (1990), Mimesis as Make-Believe: On the Foundations of the Representational Arts. Cambridge Mass., Havard University Press.

Waugh, P. (2003), Metafiction. The Theory and Practice of Self-Conscious Fiction. London \& New York, Routledge [1984].

Wesseling, E. (1991), Writing History as a Prophet. Postmodernist Innovations of the Historical Novel. Amsterdam/Philadelphia, John Benjamins.

Wolff, F. (2004), “Quem é bárbaro?”. In: Novaes, A. (ed.), Civilização e Bárbarie. São Paulo, Companhia das Letras: 19-43.

Woods, J. (1974), The Logic of Fiction. Paris, Mouton; (2010), A Mecânica da fiç̧âo. Lisboa: Quetzal. Zagajewski, A. (2003), En la belleza ajena, trad. esp. A. E. Diaz-Pintado Hilario, Valencia, Pre-Textos. 
(Página deixada propositadamente em branco) 


\section{Maria de Fátima Silva}

Professora Catedrática da Faculdade de Letras da Universidade de Coimbra e Investigadora do Centro de Estudos Clássicos e Humanísticos da mesma Universidade. A pesquisa que tem realizado reparte-se entre traduçốes e estudos sobre o teatro grego, de Aristófanes e Menandro, de Ésquilo e de Eurípides; de historiografia grega, e de Heródoto em particular; para além de estudos dedicados à pervivência de temas clássicos em textos dramáticos portugueses. Tem colaborado regularmente com diversas Universidades estrangeiras, em Espanha, França, Grécia, Brasil, como docente e conferencista. Destacam-se, entre outras publicaçōes: Ensaios sobre Eurípides, Lisboa, 2005; Ésquilo, o primeiro dramaturgo europeu, Coimbra, 2005; Aristófanes. Comédias I (coordenação e colaboração), Lisboa 2006; Furor. Ensaios sobre a obra dramática de Hélia Correia (coordenação e colaboraçáo), Coimbra, 2006; Ensaios sobre Aristófanes, Lisboa, 2007; Menandro. Obra completa, Lisboa, 2007; Aristófanes. Comédias II, Lisboa, 2010 .

\section{Tereza Virgínia Ribeiro Barbosa}

Atualmente é professora associada da Universidade Federal de Minas Gerais (UFMG), ministrando cursos na Faculdade de Letras e na Faculdade de Belas Artes/Teatro. Atua tanto na graduação quanto no Programa de Pós-Graduação em Estudos Literários da UFMG. Tem experiência na área de Letras, com ênfase em Tragédia Grega e pesquisa, principalmente, os seguintes temas: traduçáo, épica grega, drama satírico, mitologia, literatura clássica e outras literaturas (portuguesa e brasileira), tradição e renovação na literatura. Participou da elaboraçáo do Dicionário Grego-Português e desenvolve trabalhos também nas áreas de Teorias da Tradução, Teoria da Literatura. Traduziu Os Icneutas, os sátiros rastreadores de Sófocles (2012), Editora UFMG. 
OBRA PUBLICADA

COM A COORDENAÇÃO

CIENTÍFICA

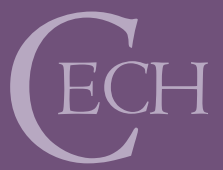

CENTRO DE ESTUDOS

Clássicos e Humanisticos

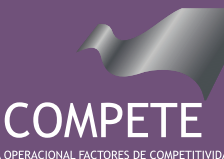

$\mathrm{QR}$

QUADRO

DEREFERENCIA

ESTRATÉGICO

NACIONAL
PORTUGAL2007.2013

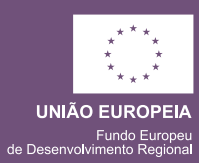

- $\mathbf{U}$

C •

I

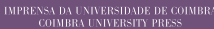

U 